\title{
THE CONSERVATIVE PARTY CRISIS
}

\section{9-1931}

Stuart Ryan Ball

A Thesis Submitted for the Degree of PhD at the

University of St Andrews

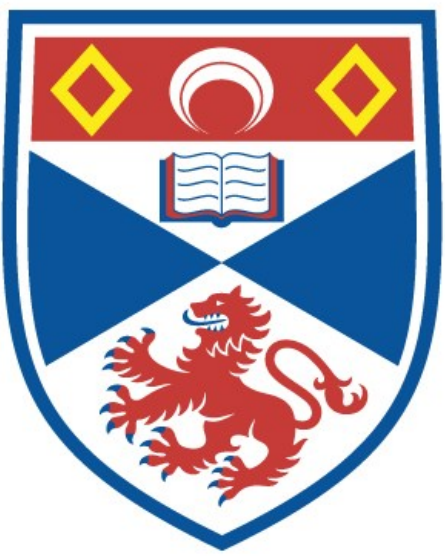

1983

Full metadata for this item is available in

St Andrews Research Repository

at:

http://research-repository.st-andrews.ac.uk/

Please use this identifier to cite or link to this item:

http://hdl.handle.net/10023/14298

This item is protected by original copyright 
THE CONSERVATIVE PARTY CRISIS 1929-1931

Stuart Ryan Ball

\author{
University of St. Andrews \\ Ph. D. Thesis \\ March 1983
}

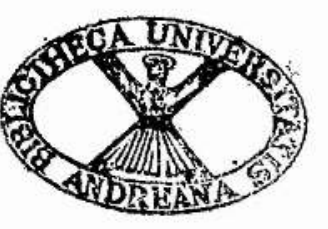


ProQuest Number: 10166563

All rights reserved

INFORMATION TO ALL USERS

The quality of this reproduction is dependent upon the quality of the copy submitted.

In the unlikely event that the author did not send a complete manuscript and there are missing pages, these will be noted. Also, if material had to be removed, a note will indicate the deletion.

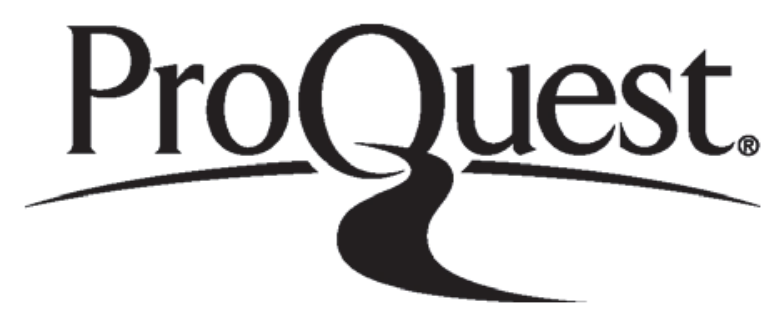

ProQuest 10166563

Published by ProQuest LLC (2017). Copyright of the Dissertation is held by the Author.

All rights reserved.

This work is protected against unauthorized copying under Title 17, United States Code Microform Edition (C) ProQuest LLC.

ProQuest LLC.

789 East Eisenhower Parkway

P.O. Box 1346

Ann Arbor, Ml $48106-1346$ 
Th 9832 
The thesis covers the politios of the Conservative Party from the general election defeat of May 1929 to the formation of the National Government in August 1931 . It relates the internal crisis in the Party to the pressures of the Party rank and file, and to the general political and economic situation, in order to analyse the process by. which Party policy evolved. Debate centred upon two questions: protection and India. In the case of the former, the role of its advocates in the press is discussed. Overall, the thesis emphasised the power of the position of the Party Leader, Baldwin.

The Party crisis passed through six distinct phases. In the first (May-August 1929) the status quo in policy was preserved; but during the second (September 1929-March 1930), the balance tilted in the direction of advance over protection, but was restrained by the reluctance of the northern regions. A truce with the press followed (MarchJune 1930), but collapsed in mid-summer, leaving the leaders dangerously out of touch with their followers' views during the fourth phase of acute crisis (Julyoctober 1930). At the end of the latter period the leaders accommodated their position, appeasing all but a small minority of dissidents, and isolating the press campaign. However, the fifth phase (October 1930-March 1931) saw a renewed outbreak of unease, due to the question of India and the leadership failures of Baldwin himself. In the final phase (March-August 1931) Baldwin re-established his position, and the Conservatives seemed set for electoral victory, having united around the policy of reducing government expenditure. The Party did not seek Coalition, but was diverted into joining the National Government by the sudden and serious financial crisis, believing it to be a temporary emergenoy expedient. 


\section{AUTHORSHTP DECLARATION}

I, Stuart Ryan Ball, hereby certify that this thesis, which is approximately 97,000 words in length, has been written by me, that it is the record of work carried out by me and that it has not been submitted in any previous application for a higher degree.

\section{date: 27 th march 1983 signed:}

I. was admitted as a research student under ordinance No. 12 on i October 1978 ard as a candidate for the degree of PHD on 2 May 1979 ; the higher study for which this is a record was carried out in the University of st. Andrews between 1978 and 1983 .

\section{date: 27 th March 1983 signed:}

I hereby certify that the candidate has fulfilled the conditions of the Resolution and Regulations appropriate to the digree of PHD of the University of St. Anorews, and that he is qualified to submit this thesis in application for that degree.

date: 27 tharch 1983 signature of supervisor: 


\section{COPYRIGHT DECLARATION}

In submitting this thesis to the University of St. Andrews I wish access to it to be subject to the following conditions: for a period of three years from the date of submission, the thesis shall be made available for use only with the consent of the Head or Chairman of the department in which the work was carried out. I understand, however, that the title or abstract of the thesis will be published during this period of restricted access; and that after the expiry of this period the thesis will be made available for use in accordance with the regulations of the University Library for the time being in force, subject to any copyright in the work not being affected thereby, and a copy of the work may be made and supplied to any bona fide library or research worker.

date: 27 th maroh 1983 signed: 


\section{PREFACE}

In the course of my research I have been assisted by the librarians and archivists of many institutions, and I should like to take this opportunity to gratefully acknowledge all their endeavours on my behalf. 1 In particular, I should like to mention the unfailing kindness of the many local Conservative Party Agents, who went out of their way to help me with access to the Constituency Association records. I am also indebted to the assistance of Mr. G. D. H. Block, OBE and the staff of the Conservative Research Department and the Conservative and Unionist Central office, and the staff at Scottish $\because$

Central Office, and at the East Midlands, West Midlands, and Yorkshire Area Offices. I am grateful to Lord Bridgeman and to Lord Kennet for permitting me to use their family papers, and to Prof. G. Jones for allowing me to borrow the West Wolverhampton Conservative Association records in his care.

It is a pleasure to acknowledge my debt to my supervisor, Dr. R. F. Mackay, for his consistent support, for many stimulating discussions at the inception of this project, and for his rigorous examination of the final drafts. I have also benefited from the experience and conversation of my colleagues in the History Department at the University of Leicester. Parts of this research were

1. A full list of these institutions will be found in the bibliography. 
considerably assisted by two awards from the Research Board of the University of Leicester, which I gratefully acknowledge here.

I owe a considerable debt to my family and my friends. In particular, I should like to thank my parents for their encouragement and support over many years; Peter Baines and John 0ldfield for their kind assistance with accommodation and proofreading; any my typist, Kelsey Sterling, for her unflappable speed and efficiency. My greatest debt of all is to my wife, Gillian, who, whilst also engaged upon historical research in another field, has always been a constant source of affection and inspiration.

Stuart Ball

Leicester

March 1983 
Introduction (i) Conservatism in Crisis 1

Introduction (ii) The Character of Stanley Baldwin 16

PART ONE - THE STRUGGLE FOR CONTROL

Chapter 1 The Shock of Defeat: May to August $1929 \quad 39$

Chapter 2 Pressures for Advance: September $1929 \quad 104$ to February 1930

Chapter 3 The Uneasy Truce: March to June 1930152

Chapter 4 The Party Meetings and the Party 209 $\therefore \quad$ Crisis: July to October 1930

Chapter 5 Beaverbrook Beyond the Pale:

264

November 1930 to March 1931

PART TWO - THE RESTORATION OF ORDER

Chapter 6 National Peril: (i) The Imperial 316

Dimension

Chapter 7 National Peril: (ii) The Domestic 372 Dimension

Chapter 8 National Crisis and National

Government: The Patriotic

Sacrifice of Party, August 1931

Conclusion Power and Authority in Conservative 


\section{Abbreviations Used in the Text}

EIA

IES

MP

NFU

TUC

UEP

Empire Industries Association

Indian Empire Society

Member of Parliament

National Farmers Union

Trades Union Congress

United Empire Party

\section{Abbreviations Used in the Footnotes}

A.

AC

AGM

An.

CA

EIA

Exec.

Div.

GP

IES $\therefore$

MP

MSS

$\mathrm{N}$.

$\mathrm{NC}$

NFU

$\mathrm{NU}$

NUA

N. W.

Prov.

Res.

S. E.

SUA

UEP
Austen [Chamberlain]

Austen Chamberlain Papers

Annual General Meeting

Annua 1

Constituency Association

Empire Industries Association

Executive Committee

Division

General Purposes

Indian Empire Society

Member of Parliament

Manuscripts and Papers

Neville [Chamberlain]

Neville Chamberlain Papers

National Farmers Union

National Union of Conservative and Unionist

Associations

National Unionist Association

North West

Provincial

Resolution

South East

Scottish Unionist Association

United Empire Party 


\section{INTRODUCTION}

\section{(i) Conservatism in Crisis, 1929-1931}

The history of British politics since the midnineteenth century is dominated by the presence and influence of the party system, both in Parliament and in spreading party organisations locally across the nation. The periods of time during which the formal party divisions of the British political system appear to have achieved stability, however, have been punctuated by intervals of crisis which have cast the mould of political life back into the melting pot. These crises can be recognised by the hallmarks of inner party strife and debate, allied to uncertainties ranging beyond the apparent issues of future party policy to concern over the whole future and nature of British politios. The party categorisations passed through a period of fluidity, in which changes of personnel, support, and intention, of a fundamental or radical nature, took place. To a greater or lesser degree this occurred to the accompaniment of open factionalisation, and the contention of leading figures, either inspired by or exploiting a new rhetoric, for power within the wider arena of political struggle. These processes, these periods of reappraisal, are sometimes obscured by the fact that the parties emerged from them often bearing the same nomenclature, comprising much the same backbench and grassroots support, and apparently unreconstructed. It is too readily assumed 
that if a grouping did not actually disintegrate, that the changes which affected it were minimal, superficial, and transient. There is no doubt that "party" as a concept has enormous survival power, and that the individual parties have acquired a claim on loyalties and a durability achieved simply through existence.over long periods. It has been more frequent and normal in the experience of the past century of British politics for changes to take place within the framework of a party, even though such changes may have strained the framework near to breaking point; rather than to cause a complete reorientation of groupings such as occurred in 1846 .

This is not an attempt to elevate these general tendencies into a system of interpretation, but rather an acknowledgement of the periodic nature of crises so generally affecting all shades of opinion that the firmest landmarks on the contemporary political horizon seem to shift, and every question is cast into "the witches' cauldron". ${ }^{1}$ Although the years in between such crises are far from uneventful, marked by bitter controversy between parties verging on constitutional breakdown, such as 1906 to 1914; or indeed may be of greater historical moment, such as the First World War itself, nevertheless these periods of general reappraisal stand out clearly from a distanced, historical, standpoint, as would junctions on a

1. Rosebery to Churchill, 7 October 1902, in R. Churchill, ed., Winston S. Churchill, Companion Volume, $2(1969)$, p. 166 . 
railway journey. Those seated in the railway carriage may notice themselves passing over some junctions, or alternative pathways, yet not feel the vibration or the consequences of others at all. They would be even more distinctly aware of the uncoupling, shunting, and redistribution of component sections of their train; but from the historian's perspective it is the choice of the different tracks, even more than the narrative of the journey itself, which attracts the most searching analysis.

To return from metaphor to reality, the periods of reappraisal are not difficult to identify. Surveying the course of British politics since 1846, the crisis of Liberalism and Conservatism in 1885-18.86 stands out as one such; the period 1900-1903 has recently and convincingly been portrayed for both main parties as another. ${ }^{2}$ There can be little doubt that the years 1929 to. 1931 represent the third. This is apparent not just in the coincidence. that each of the three major parties was racked by internal dissensions, but in the more significant fact that these problems were the product of questioning anxiety within each party concerning not only present progress, but the seeds of future intentions that were implicit in current responses. But reappraisal was not limited to the parties: significantly, it linked them as much as it distinguished them, and the air was full of 2. A. Sykes, Tariff Reform in British Politics 1903-1913
$(1979)$, pp. $1-30$. 
initiatives for mergers and coalitions, for centre groupings or new parties, all of whose programmes would have involved shifting the basic ground of politics away from the shibboleths of the immediate past, into entirely novel matters. Another indicator of the way in which the politicians were plagued by doubts was the prevalent demand for a government of businessmen, or a non-partisan National Government from the best talents of all parties; both proposals would have necessarily entailed the submergence of those issues, such as tariffs or free trade, upon which the present divides were established, in favour of a new consensus - and, although less clearly perceived by the advocates of such reconstruction, new lines of division. Hence the talk of new combinations, and the formation of a New Party; hence also the challenges and demands of the young turks against the control of prominence by an old guard. The importance of the young men's movement and their alienation from their leaders is that it claimed larger pretensions than merely to be the struggle of one generation to displace the preceding one. They claimed a fresh and novel approach, and affected scorn and contempt for both the methods and the concerns of the old politics and the older politicians. In the attempt to be as much the promulgators of programmes as the constructors of new cabinets on the backs of menu cards, the movement of the young men was an integral part of the process by which the 
structure of party distinction had been cast into the melting pot between 1929 and 1932. Of course,to a considerable extent the chance occurrence of certain factors: the hung parliament; the rise to the verges of political maturity of the generation who had served as junior officers in the fighting of the First World War; and the global economic recession, forced on all these anxieties and rendered them acute. It is possible to make a case for any period that it was a period of transition, and to become entrapped in cliche when struggling between the choice of emphasising either the "change" or the "continuity" in characterising any era. But to avoid such judgements is, in itself, no solution, but rather an abdication of responsibility. There is a strong case for suggesting that the years from 1929 to 1931 were a period of transition, from the politics which had characterised the 1920's and had their roots in Edwardian and lateVictorian Britain, to those which formed the debates of the 1930's, and in a diminishing extent, until as late as the period which may be categorised as the next watershed, that of 1961-1964.3 Though the 1930's were not without drama, it is nevertheless possible to suggest that at a basic level the politics of that decade had achieved an equipoise and stability which had been lacking from the 1920's. Due to the imminence and occurrence of the Second World War, and the fascist threat, and due also to the

3. A. Sked and C. Cook, Postㅡaㅡ B Britain (1979), pp. 910. 
consequent attention of commentators to the 1930's as opposed to the neglected mid and late-1920's, it has become customary to picture the contrast in the opposite direction. Yet it was the 1920's, with the political and economic consequences of the First World War, with the instability of the party system after the Coalition experiment and the complexities of genuine three-party politics, with the problems of the emergence of Labour governments and of the General strike, and with their frequent general elections, which in fact have the character of a period preceding a cathartic restructuring, whilst the 1930 's exhibit an essential structural stability which follows from such a recasting. This may go much of the way to explain the failure of the initiatives for new parties, launched in the period of flux, to survive or prosper in the new decade, and the failure also of extremist groups of the radical left or radical right to achieve the destruction of a reestablished two-grouping system.

The fortunes of all the parties, the careers of almost all the leading figures of both politically active generations, and their mental outlook or "world view", in the unconscious evolution of attitudes from one viewpoint to another, were significantly affected by the events and arguments of the span from the general election in May, 1929 to the period when new grooves had been settled into, apparent sometime between 1931 and 1935. In each case these latter can be dated differently. For the Liberals 
the choices taken during the minority second Labour administration, and in particular from the formation of the National Cabinet in August 1931 to the withdrawal of the Samuelites from that government in 1932, and their eventual symbolic return to the opposition benches, dictated their political significance, in terms of their exclusion from hope of office in peacetime until at least the Grimond revival of 1961-1964, if not the Alliance of the early 1980's. For the Labour Party, the tensions of the second government, and the eventual rift of August, 1931 and the process through which the party emerged to become more clearly the party of the TUC and of Attlee, for at least the twenty years after 1935, if not for longer, marked the shedding of its late-Victorian background and leadership. In the Conservative Party the debate began and ended slightly earlier, in the months from defeat in the spring of 1929 until the mid-summer of 1931, though after-effects of the decisions taken over India rumbled on until 1935. For the Conservative Party the formation of the National government in August 1931 was not the catalyst of the process of reappraisal that it became for the other two parties, but was rather something of a distraction from decisions already arrived at, perhaps unwittingly, as well as being a confirmation of them. The logical consequences of the options selected between 1929 and 1931 did not in some areas become fully apparent until afterwards, when they produced internal protests; but this pattern should not be allowed to 
obscure the fact that the important choices had been taken already.

The historiography of these crucial years is patchy, signifying as it does an area of work in progress, rather than of work completed. Some of the ground has been touched on in the form of background in the many biographical studies, to a greater or lesser depth, but always within the confines of the individual subject's perspective. Of the three parties, Labour has perhaps been best served. Apart from the comprehensive account in the biography of Ramsay MacDonald, 4 there exists Skidelsky's monograph on the 1929-1931 government, as well as his biography of Oswald Mosley. In addition, the crisis of the Labour cabinet in August, 1931 has been given considerable attention from this angle.5 The Liberal party has also received considerable historical attention, most usually within the framework of questions concerning that party's decline. The lessons of Michael Bentley's work, whilst ostensibly limited to the years until 1929, in fact contain the basis for understanding

4. D. Marquand, Ramsay MacDonald (1977).

5. R. Skidelsky, Politicicans and the slump: the Labour Government of 1929-31 (1967); D. Cariton, MacDonald versus Henderson; the foreign policy of the second Labour Government $(1970)$; R. Basset, 1931 : Political Crisis $(1958) ;$ R. Skidelsky, Oswald Mosley (1975); H. Berkeley, The Myth that Will not die : the formation of the National Government, 1931 (1978). 
the Liberals' preoccupations in the following three years. Trevor Wilson has analysed the positions of leaders and of party organisation, and the role of Lloyd George has received much attention. ${ }^{6}$ Paradoxically, it is the Conservative Party, the party of government during most of the inter-war years, and arguably the party most profoundly and permanently affected by the 1929-1931 crisis, which has received minimal attention. Only. John Ramsden's general work of interpretation of the party's history from 1902 to 1940 explores the issues beyond the biographical in any depth of commentary or source materials; and in such a general work space for even such important issues must necessarily be limited.7 As a number of the most important surviving collections of private papers relating to Conservatism in this period have become available only recently, it is now possible to attempt to redress the gap in the interpretation and understanding, not only of the history of the Conservative Party, but also of the workings of British politics during the inter-war decades. The theme of the period of

6. T. Wilson, The Downfall of the Liberal Party $1914-$ 1935 (1966); M. Bentiey, The Liberal Mind 1914 =1929 (1977); R. Douglas, The History of the Liberal Party $1895-1970$ (1971); S. Koss, "A squith versus Lloyd George: the last phase and beyond", in sked and Cook, eds., Crisis and Controversy (1976); J. Campbell, Lloyd George: the Goat in the Wilderness $1922-31(1977)$.

7. J. Ramsden, The Age of Balfour and Baldwin 1902-1940 (1978); A. J. P. Taylor, Beaverbrook (1972), also discusses these events, but is based only on the Beaverbrook papers. 
reappraisal, and its context in the general system of politics, thus pervades this study and provides its setting.

However, this thesis can be considered also as a case study in the workings and history of the Conservative party as an institution, in the sense that examination of the Conservative Party's internal crisis of 1929 to 1931 may also illuminate several themes which dominate the history of the party in the first half of the twentieth century. The most obvious of these concerns the character, the composition, the structure and organisation of the Conservative Party itself. Within that, four other questions deserve to be specifically identified. The first and most important of these questions concerns the nature and position of the party leadership, and above all of the leader. His power, and the limitations of that power, his relationship with his followers within and without the Houses of Parliament, must in any study of the Conservative Party be a point of first departure. This is doubly so for the period of Baldwin's leadership, for there can be nogainsaying the importance of his tenure as party and national leader; in particular in the context of the decisions of the early and mid-1930's on domestic and international matters. The character, methods and aims of Stanley Baldwin will inevitably figure very largely as the first of the four threads interwoven throughout this study. 
The second question that presents itself is that of the politics of tariff reform in this, their final, phase. The importance of protectionism, as an issue in politics and in its impact on the party, is alearly immense, and it has been vividly illuminated in Alan Sykes' study of the topic in the Edwardian era. 9 The contrast between the politics of idealism and the politics of electoral pragmatism, and the struggle between these which was fought on the issue of the food tax aspect of tariff reform, thus also dominated the history of the party before as well as during the period under examination in this work.

A third area of great concern to any history of the Conservative Party that touches on the inter-war period must be the question of coalitions and coalitionism, of the way in which Conservatives perceived the party system and made judgements about the nature of government and the validity or danger of different governmental combinations. The road from the wartime coalitions of Lloyd George, and especially from the renouncing of that course at the Carlton Club in October 1922 to the formation, by essentially the same group which had rebelled against coalition on that occasion, of a National three-party ministry in August, 1931 and of the Conservative Party's continuation in ostensibly non-party government from that point until 1945, obviously deserves serious historical

9. Sykes, op. cit. 
examination. ${ }^{10}$ There can be little doubt that the origins of the decision of August 1931 were contained within the political and economic events of the period from spring, 1930 to autumn 1931, and the tracing of these events will also therefore be a major concern of the present study.

The fourth theme is to some extent a product of the concerns of the second, being the Conservative Party's attitude to questions of imperial defence and foreign policy. The relevance of these to the world events of the decades from 1933 to 1963 hardly needs justification. The idealists of tariff reform in the Edwardian era saw their policy as being in part or in whole the answer to these problems. However, by the late 1920's and throughout the $1930^{\prime}$ s these matters took on dimensions wider than those of imperial preference alone. These concerns may be loosely lumped together under the phrase "Empire policy" as it was in that wider sense that the rhetoric of Empire dominated Conservative Party politics. The essential issue was the primacy of domestic social and economic factors over pretensions to a world role, and the expensive responsibilities entailed by the latter. Although the continued survival of the rhetoric of Empire has obscured this fact, it is a major contention of the present work that in this short period the changes in

10. This theme has been explored in the general context

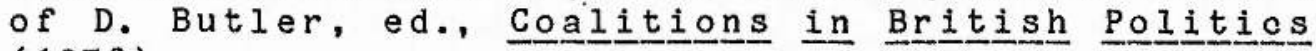
$(1978)$. 
attitude of the Conservative Party to the relationship of home and empire passed through a decisive phase, and that decisions were taken which consciously or unconsciously turned Britain on the path away from world status and towards insularity. To reduce the British Empire to its only important parts was to reduce it to the Indian subcontinent and the white Dominions and colonies of settlement: Canada, Australia, New Zealand, Eastern and South Africa. The remainder had significance only as strategic points on the routes to these areas, such as Egypt, Aden and Singapore, rather than in their own right, or were simply the unimportant remainders of areas acquired by accident or in the wars of the remote past. Viewed in this light, the crucial significance to the imperial party of policies which affected fundamentally Britain's relations with both these areas, in constitutional reform with native India and in tariff reform in the question of imperial unity with the white colonies of settlement, is readily apparent. Connected with these were the related questions of imperial defence and communication: of the British position in Egypt, at Singapore, and in terms of a powerful navy.

In this period crucial decisions were taken over all these areas. In tariff reform the policy changed from imperial unity to the protection of domestic industry, so that the ending of free trade in 1932 did not produce the imperial consequences hoped for by the proponents of it during the previous thirty years. In parallel with this 
the debate over the future government of India was also subordinated to domestic concerns by the way in which it became apparent as early as the end of August 1931 that the Party, whatever the doubts of one section, would never smash the National Government on the issue of India. The excluded politicians of the settlement of August 1931 were Amery, Churchill, and Beaverbrook, for their world view no longer synchronised with the majority of their party, whatever the occasional emotive appeals of their speeches. The developing primacy of home over empire is fundamental to explaining the progress of the Conservative Party to a position of presiding relatively painlessly over the decolonisation of the late-1950's and early-1960's, and to its acceptance of Indian independence after the second World War. It is also crucial in any analysis of the major crises of the 1930's, and why, as Maurice Cowling has illuminated, it was the major area of politioal discussion. It becomes evident not only over the economy and India, but also over rearmament, the Singapore naval base, and the League of Nations; over the question of British responsibilities as a world power and as a European power. 11

11. M. Cowling. The Impact of Hitler: British Politics and. Brittish Policy $1933=1940$ (1975); G. Peele, Thevolt over Indiat, in PeeIe and Cook, eds., The Politics of Reappraisal 1918-1939 (1975); R. P. Shay, British Rearmament in the Thirties: Politics and Profits $(1977)$. 
In addition to these wider themes concerning the nature of Conservatism and of Conservative Party politics, another important historical issue is interwoven in the narrative of these events: the question of the extent and the influence of the power of the press. More specifically, perhaps, this might be categorised as the power of the politically active proprietors of great new papers - the press lords. Whilst playing a crucial role in the concerns of the present work, however, the topic has been approached not from the standpoint of an analysis of the role of the press in British political life, though illumination may be thrown upon that topic in passing, but from the direction of a study of party politics. This is more than just a question of methodology, for it has been one of the strongest conclusions of the present study that, notwithstanding the apprehensions and fears of newspaper influence held by contemporaries in this period, the power of the press per se was of little significance unless it happened to vocalise or organise a substantial body of opinion alienated from, or unrepresented by, the existing groupings or leaders. The power of the press lords was conditional upon this, and when they lacked support outside their own premises in Fleet street, their inability to affect the larger issues was. fully revealed. Howher, on such occasions as they became the focal point of grassroots or backbench disaffection, their strength was given substance. Yet to mobilise such movements, the establishment of a pressure group or even a party, the 
contesting of elections, the raising of funds, and the enlistment of ordinary supporters, were a necessary feature, as can be seen in the newspaper campaigns of 1920-1922 as well as those of 1929-1931. Once operating in this arena, the press lords have become party politicians, albeit of a novel kind, and thus their actions can be better analysed from that perspective.

\section{(ii) The Character of Stanley Baldwin}

The several biographies of Baldwin have all been, in one way or another, ultimately unsatisfactory in illuminating his motivations and attitudes, and to a surprising extent his character still remains obscure. This is partly due to the frequently acknowledged, but as yet not fully analysed, complexity of his personality; and partly due to the fact that he left little of his personal thought processes in the written historical record. Baldwin was not a great letter writer, preferring the informal conversation, while in the case of his immediate family his separations from them, and thus the need to correspond, were few. He kept no diary, and his letters eschewed political commentary or self-revelation. The Baldwin papers contain little written by Baldwin himself, for unlike Beaverbrook he did not retain copies of his ordinary correspondence. The Baldwin collection consists largely of letters received from others, and of official. papers and party memoranda, together with copies of purely 
formal and public letters concerning official appointments, or intended for publication in the press. Thus it is only possible to piece together a contemporary picture of Baldwin from a wide and scattered mosaic of documentation, in which the accounts of colleagues and confidants of personal meetings and discussions play a far greater role than anything written by the man himself. The weakness of the published biographies stems in part from their inability to integrate this range of evidence. The flaws of the original work by G. M. Young are well known as an illustration of the dangers of the biographer becoming alienated from his subject; but it is equally a weakness of such immediately posthumous works that they are based only on the slender resources of the family papers. The two rejoinders provoked by Young's book, although of interest, were not in that sense wider in base.12 The next study, produced at the end of the 1960 's, fell into the trap of attempting to explain Baldwin by means of a very detailed narrative chronological treatment, resulting in a very long book in which Baldwin's character became submerged by the flow of events. 13 Though more material was then available, much

12. G. M. Young, Stanley Baldwin (1953); A. W. Baldwin, My Father: the True Story $(1955)$; D. C. Somerveli, Stanley Baldwin $(1953)$.

13. K. Middlemas and J. Barnes, Baldwin: A Biogra (1969). 
was unsorted, and more still not yet open to historians. The most recent biography, despite adding one or two further collections to the list, essentially represented a narrative summation of the interpretation and account already arrived at, rather than a breaking of new ground. 14 In fact, the most illuminating treatments of Baldwin have come comparatively recently in the form of several articles. ${ }^{15}$ These provide a starting point, but naturally each examines only one aspect of Baldwin's career, and not the whole. Yet with the range of material now available to the historian in the 1980's, it is possible to at least commence the process of interpreting the character, motivations, and actions, of this important and fascinating figure. Although it is dangerous to rely entirely upon second-hand attributions of motive, the accumulated weight of evidence is such as to permit the isolation and discussion of certain themes.

Baldwin was inclined to think of politios in terms of a sense of duty and obligation. The sacrifice of younger men in the First World War had profoundly affected this sentiment, which found one expression in his anonymous

14. H. M. Hyde, Stanley Baldwin (1973).

15. D. Southgate, "Baldwin 1923-1932", in D. Southgate, ed., The Conservative Leadership 1832-1932 (1974); J. Campbel1, "Baldwin", in J. P. Mackintosh, ed., British Prime Ministers in the 20 th Century (1977), Art", in Midland History, volume 4, no. 2, 1977; P. Wili amson," safety First": "Baidwin, the Conservative Party, and the General Election of 1929", Historical Journal, volume 25, no. 2, 1982. 
gift of a substantial portion of his private wealth to the nation for the cancellation of war debt. This view was also based on a religious conception of the purpose of public life. Baldwin's premise was that good works could not come from the hands of tainted vessels, and it was this attitude that made Baldwin reluctant to ever consider alliance with Lloyd George. It was not just a fear of being personally supplanted by the latter's political skills in government, but rather a deeper fear of the likely consequences of allowing the morally corrupt to return to the heart of power. Baldwin felt that the virtues of honesty and trustworthiness were the essential foundation for any attempts at creating some lasting achievement in political life. Thus when he considered dealing with the, unemployment problem by introducing tariff reform in 1923, although he had a parliamentary majority willing to pass such a measure without a dissolution, he went out of his way to honour a promise made by his predecessor, Bonar Law:

That pledge binds me ... and I take those words strictly. I am not a man to play with a pledge.... I am not a clever man. I know nothing of political tactics, but I will say this: having come to that conclusion [that tariffs are necessary] myself, I felt that the only honest and right thing, as leader of a democratic party, was to tell them.

16. The Times, 26 October 1923. 
It was this stance, as much as considerations of electoral pragmatism, which prevented Baldwin from adopting Beaverbrook's programme of Empire Free Trade, even after the failure of his platform of honesty and trustworthiness to win the general election of 1929. He was aware of the barrier posed to Beaverbrook's concept by the Dominion statesmen upon whose voluntary acquiescence the plan depended, and was thus aware of the policy's essentially unreal, even fraudulent, nature:

no responsible statesman could ... tell the electorate that it would be introduced if he were returned to power. It cannot be done. The Dominions won't have it - they have said so in the clearest terms ... no political party in this country can honestly adopt Empire Free Trade.

From Baldwin's viewpoint, the emphasis on character was un arguably more relevant and useful than the unstable cleverness exhibited by the high priests of the Coalition: Lloyd George, Churchill, and Lord Birkenhead. He was always more concerned with reliability, and a certain solidity; not the product of stupidity but of a consistency based on clear principles or standards, consciously or unconsciously held to. In that sense he often found it easier to comprehend the attitude of Labour politicians, while distrusting the erratic and expedient

17. Baldwin interviewed in Home and Empire, no. 1, March 1930 . 
manoeuvres of the Liberals. The volatile and inconsistent policies of the Lloyd George coalition between 1920 and 1922 were a complete anathema, redolent of a shiftless desire to remain in power regardless of purpose.

These attitudes were a part of his traditionalism, of his conception of what the true English character was and should be like, of virtues associated with the supposed structure of society in the "shires", of the responsibilities more than the privileges of being a gentleman. All those attitudes were a successful part of Baldwin's public image, and as such were naturally magnified at the expense of his other traits in the public eye. Though not the whole, they were still genuinely a part of Baldwin's own personal world view, and in that sense were a natural if exaggerated manifestation of his private thoughts. It has been pointed out that such an evocation of the mythical side of rural England was a totally inapproriate diversion from the problems of an industrial urban society. In one sense this is clearly true, but it begs the issue of the demands of the public mood. Nostalgia for the half-remembered past was something Baldwin reflected rather than created; and reflected not so much out of calculation, but because of the chord such feelings struck in him just as much as in anyone else. The crucial point about Baldwin's love of the countryside is precisely the fact that his family background, though semi-rural, was not agricultural but industrial: this has in fact mislead commentators into 
assuming that his emotional self-identification with the shires sprang from his background. In fact it did not, for Baldwin's love of the countryside was an example of that same heartfelt longing so often found in the inhabitants of British cities and suburbs, all the stronger a force for the contrast between the idealisation of something largely unknown and the alienation from an urban existence which seemed to be dehumanising. 18 Baldwin's image of the proper structure of society was also appropriate in another sense; in the arena of the Disraelian myth or tradition of one-nation Toryism. It was this, together with the Victorian role of the Liberal party as representative of the middle classes of the cities, hostile to the Church, which made Baldwin a Unionist in his early politics despite the possession of several semi-liberal attitudes. In this sense the evocation of an idealised past, the rejection of class politics and thus in part of industrialisation itself, in favour of a commitment to politios as being not concerned with bread and butter issues but with the church and the constitution, were hardly novel features in the Conservative Party, and certainly were not foisted either on it, or on the nation, by any one figure.

18. M. J: Wiener, English Culture and the Decline of the Industrial spirit $1850-1980(1981)$, pp. $96-111$. 
Neither were other cardinal features of Baldwin's character. These were in fact held in common with most other Conservative politicians, and were a product of the attitudes and ideals of the public school, and to a lesser degree, university education through which they had all passed. Baldwin had absorbed these influences passively and unquestioningly; indeed, so completely did he find security in the team-game spirit of collective endeavour and mutual loyalty that the demands of striving for excellence via individual competition proved beyond him. So also he found no satisfaction in the adversarial side of politics. In this he only differed from others of similar background in the degree, rather than the concept. Many viewed the party system as a cricket match between two sides, and loyalty to your own team and its captain went hand-in-hand with respect for good bowling, or defensive batting, by an opponent. Again, in this system, there was no place for a third and unreliable team; the Liberal party of the 1920's: On many occasions, especially during general elections, Baldwin shared this view. On others, in the clubbish atmosphere of the Commons, he sometimes saw all leading figures as part of the same team of 'statesmen', kept apart by petty prejudices; sometimes in league against their own misguided supporters, more often playing in the world arenas as the representatives of Britain. Though Baldwin did not plot or plan for the formation of a National Government, suspicious critics were right to detect that 
he held no deep loyalty to the party system, and once convinced that the team so formed would be of a trustworthy kind, he had no real objection to the arrangement. This does not imply a reversal of his condemnation of coalition in 1922, for, as was shown by his acceptance of promotions within that Lloyd George coalition, Baldwin did not reject the appeals of national unity; but only the way in which, after his joining of Lloyd George's cabinet, he discovered such sentiments were being cynically abused as, in Baldwin's eyes, a noble sentiment betrayed for personal ends.

Baldwin's public reputation as the straight and honest man was a role thrust upon him by the events surrounding the fall of the coalition. It then partly reflected his inexperience of the centre of the political stage. However, the fact that between 1922 and 1929 his conduct had not lessened, but rather augumented his reputation in this respect - to the point where the 1929 election strategy was largely founded upon it - is highly revealing of Baldwin's modus operandi. It was also to prove a resource of inestimable advantage when Baldwin came during the party crisis to cast himself for the public in the role of the honest man maligned by an irresponsible, and vindictively unfair, press. The part was all the more convincing in that to the public eye Baldwin personified the plain, simple, but honest man in politios: 
Mr. Baldwin is slow, but he is honest. I trust him and honour him. I do feel that apart from loving his country he understands the man in the street.... I will not have my politios dictated to me by the Daily Mail or Daily Express....

wrote one of the self-confessed "men in the street" in 1930.19 This reflected the fact that in the country as a whole Baldwin's position was always stronger than it was within his own party, and much of his value as party leader electorally lay in that very ability to attract 'middle opinion' in a way in which potential successors, Hailsham or Neville Chamberlain, probably could not have done.

Despite the political advantages it brought, Baldwin's mixture of honesty and loyalty cannot be dismissed as merely a politician's public facade; even if it was a strong card to play against Lloyd George and his former coalition cronies. For Baldwin made himself vulnerable by defending out of loyalty two figures to whom he felt personally committed, Davidson and Lord Irwin, whose policies were anathema to a large element of the party he led. This tendency to adhere to pledges or personal loyalties led him into political danger. Not the least effective cry against Baldwin during the party crisis was the continued presence of the 'old Gang' of excabinet ministers as the party's dominant group. Despite

19. Fleet ["I am one of the men in the street"] to Hannon, 1 July 1930, Hannon MSS, $19 / 1$. 
pressure to drop some of the less able of these, and his own often-announced, though rarely practised, desire to bring on younger talents, he proved strangely reluctant to appease these demands. This is partly explicable in the light of another aspect of Baldwin's character evident in this period; his preference to allow events to take a natural course in the hope of avoiding difficult decisions - a policy he adopted later in the abdication crisis. It may also point to a certain laziness, or hesitancy to act, in the sense that Baldwin was always reluctant to commit himself fully or fervently to any course - not least because of the difficulty of later pulling back. This attitude of caution was to prove a major disappointment to the advocates of tariff reform in 1930, who sought the fervour of the convert, not the pragmatism of the political strategist. Baldwin's failure to drop the "old Gang" despite the considerable agitation onthe matter also reflects the personal conservatism of a shy figure, who has become accustomed to certain colleagues, and is not eager to repeat the process with a new and more remote generation. But more than any of these other factors, his attitude on this question of loyalties was of a piece with his political character. Despite frequent advice to reconstruct his cabinet before the 1929 election, Baldwin did not do so. It was not simply that he was not a good cabinet 'butcher'; the feeling that restrained him from 
carrying through such a move, despite its political advantages, was that it offended common loyalty.

only one area of politics consistently aroused Baldwin's close interest: those questions which broadly came under the heading of the constitution. This was evident in small things as much as large, in his care over patronage appointments and caution over the granting of honours, and in his conception of the proper role of the Prime Minister. Though hardly a naive idealist, he nonetheless saw the premiership as being at least in part above party; hence the attention he gave to fulfilling non-political roles and providing leadership in fields outside conventional politics: many of his best speeches were in the form of ceremonial or celebratory occasions, anniversary or rectorial addresses. Whilst Premier he devoted muoh time to this area of national life, prizing it above political debate. This theme was apparent on larger scales. Baldwin saw the emergence of class divisions as the base of politics as adanger to constitutional government, as he also did world war, and on both occasions chose to appease, using that word in the sense of reconciliation rather than concession. Thus the appeasement of the Labour Party was the other side of the coin of appeasement of Germany, both being pursued in the interests of stability, peace and tranquility. All of Baldwin's great political battles were fought over constitutional issues, from the unconstitutional nature of Lloyd George's presidential government, through the 
general strike, the issue of Indian constitutional advance, and the question of the proper role of the press, to the abdication crisis at the end of his career. It can hardly be a coincidence that the most silent phase of Baldwin's House of Commons career, as a backbencher between 1909 and 1914, occurred during the period when his instincts of party loyalty must have been to some extent in conflict with his constitutionalism.

Baldwin's speeches contain many remarks denigrating intellectuals and intellectualism, and it was against this that he continually contrasted the "simple" virtues. He saw many dangers in systems of political thought, and his anti-intellectualism was a rejection of systems rather than of brains as such. To Baldwin the possession of intelligence was a God-given talent to be used, but with becoming modesty; once again, a reflection of the conformist ethos of the middle years at public school rather than the atmosphere of the university. A glorification of intellectual power was thus either a cover for the shallow opportunism, such as he perceived in Birkenhead, or for the dangers of the inhumanity and rigidity of the theoreticians, be they economists or philosophers, Keynsian or Marxist. Baldwin by education and by nature, like Churchill, pursued the politics of instinct. In this he was not much removed from many Labour figures, whose socialism was founded equally on Christianity and upon instincts and background. For 
Baldwin the background and the concerns were different, but not necessarily incompatible. This did not imply shallowness, for as Tom Jones wrote, "he felt things deeply, and his conscience was more active than his intellect". 20

In the period of opposition and internal bitterness between 1929 and 1931 Baldwin was the creator of many of his own difficulties. Several of these were the product of defects in his own character. His weaknesses of personality are a frequent source of comment: his laziness, his complacency, and his nervous indecision. As Prime Minister between 1924 and 1929 his colleague Bridgeman commented on "his extreme reluctance to comit himself to one side or the other in a dispute until the last moment, when he was obliged to do so."21 This extended to his methods of doing business with his colleagues on a day-to-day basis. Austen Chamberlain complained:

I have never known so blunt a spearhead as $S$. B., or a man who left so large a gap between the recognition that he must act and action. Whenever you have settled something with him one day, you must seek him out the next to ask if he has yet done it or even put it in train .... 'Too late and in the wrong way' sum up my criticism of his leadership.

20. Tom Jones' diary, quoted in R. R. James, The British Revolution (1977), volume 2, p. 180.

21. Bridgeman Journal, volume II, p. 183.

22. A. to Ida Chamberlain, 22 June 1930, AC 5/1/506. 
Baldwin's attitudes led also to complacency, based in part on an excessively optimistic appreciation of his personal political position. This buoyed him up through the early phases of the party troubles, but could not completely conceal his growing unpopularity. In october 1930 Neville Chamberlain noted that

he has at last I think come to understand how low his stock has fallen, but the effect seems rather to cow and stupify him, than to inspire him with any sort of determination or capacity to take a decision. I feel very sorry for him for $I$ am afraid he is very unhappy.

In fact he was a prey to insecurity and nervousness, which manifested itself in several ways, one of which was his hakit of licking the order papers whilst listening to colleagues' speeches in the Commons. This nervousness led also to indecision, and resulted in the process by which it took Baldwin much time and mental effort and anguish to come to any major decision, a habit which on occasion had its own dangers, either of actions taken half-heartedly or too late. Equally serious was his tactlessness in the handling of his colleagues. In his personal relations Baldwin was probably a worse operator as premier even than Gladstone had been. Frequently he allowed his confidants to leave offices held at his request without any message of gratitude or condolence, as happened with both Davidson

23. N. to Ida Chamberlain, 11 October 1930, NC 18/1/712. 
and Neville Chamberlain on their relinquishing of the party Chairmanship. One explanation offered was that "he seems to ... distrust or actively dislike most of his colleagues and to be afraid of all his opponents and of himself."24 On the occasion of Neville Chamberlain's standing-down in March 1931 his half-brother Austen wrote of Baldwin's conduct that

nothing could have been less gracious than the latter's attitude: though. I think this is more inability than purpose, it does spring in part from his being so self-centred that he receives all we give him as a matter of course and takes offence at the least sign that we are not completely at his service for whatever use he likes to make of us.

Allowances might be made for Austen's wounded amour propre as a former leader of the party, but similar evidence comes from too many other sources to be so easily dismissed.

Baldwin was also an erratic performer on the platform, and his efforts were directly related to the interest they aroused in himself, rather than to their political significance. Thus a Rectorial address received considerable thought and polishing, but the speech to

24. A. to Hilda Chamberlain, 14 June 1930, AC 5/1/504.

25. Ibid., 21 March 1931, AC 5/1/535. 
party conference in 1929, a critical utterance, did not. It contained "no argument to speak of, no building up to a climax. He is incorrigibly slovenly about a speech of that kind which doesn't really appeal to him."26 However, his ability as a public speaker on occasion was also the source of Baldwin's strength. He has been categorised as the quintessential House of Commons man: constant attender, possessing the ear of the House and a calm dominance over it, and its moods, unparalleled between the wars. 27 This may have been true of the years of his rise to prominence; it certainly was not true of the period of the party crisis. Complaints of his absenteeism from the House abound, as do those of his aloofness and inaccessibility to his backbenchers, and his total disinterest in the cultivation of the younger element. 28 Hannon later wrote of the way in which Baldwin

treated me - as indeed he treated all his supporters - with an indifference in which his self-esteem and his exaggerated concept of his own importance clouded whatever fragments of statesmanship he made claim to possess.

26. N. Chamberlain diary, 8 December 1929, NC $2 / 22$.

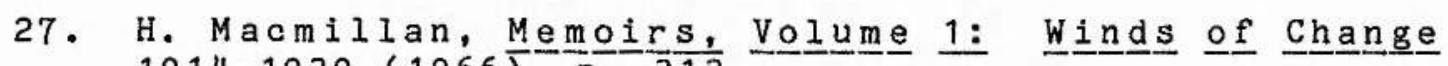
1914-1939 $(1966)$, p. 313.

28. H. Balfour, Wings Over Westminster (1973), p. 76.

29. Hannon to Beaverbrook, 12. September 1955, Hannon MSS 17/1. This was, it must be admitted, a comment between two figures with little political affection for Baldwin, written at the period of his lowest public reputation: but it conveys pithily sentiments reciprocated widely elsewhere. 
Neither was it true to suggest that Baldwin was even moderately good as a House of commons debater in any consistent fashion:

He has no House of Commons gifts, can't debate or think or act quickly, and always addresses [Ramsay MacDonald] as if he were a lower schoolboy who had undertaken to voice the discontents of his comrades and knew that he would be swished before he got out of the room. And with it all, he is so terribly complacent, ...

whilst on another occasion he was categorised as "useless in the House". 30 In part these were the defects of being in opposition, for, as Baldwin himself recognised, he did not shine as an opposition leader. This was a question of a temperfment, and a sign of Baldwin's failure to fulfil some of the more partisan and adversarial roles incumbent in the party political system. He was, on the contrary, noted for "his wonderful generosity to his opponents. He never attacked them when they were down, and always treated them with a remarkable considerateness ... this virtue carries with it the compensating vice of not being very good at the attack." 31

Despite these failings, Baldwin lasted for almost fifteen years as party leader, retiring at a momt of his own choice, and he succeeded in riding out the buffets of

30. A. to Hilda Chamberlain, 21 March 1931, AC 5/1/535; A. to Ida Chamberlain, n.d. but c. June 1931, AC $5 / 1 / 541$.

31. Bridgeman journal, volume 2, p. 183. 
the party crisis if not unscathed, at least not unseated. His strengths were as considerable as his weaknesses. Principal amongst these was the extraordinary power he could on occasions summon up on a theme or issue about which he felt deeply, and which made some of his set-piece speeches so effective. This ability was exhibited on several occasions: in February 1923 in his evocation of 'Faith, Hope, Love and Work' for industrial peace, and on the same theme in his 'Give Peace in our Time, O Lord!' speech inthe Macquisten Trade Union Bill debate of 1925 . This ability to suddenly translate himself onto some higher plane which was revealed on several occasions during the party crisis on the themes of India and the press, was of crucial value in an assembly where the power of oratory was esteemed above all else, and can hardly be over-emphasised. Baldwin's technique was described by one follower as:

ensnaring [his audience] with plain discourse, apparently of great moderation, which gradually bound them up in a web, unwilling not to fulfill the purpose of such a straight-forward leader.

Baldwin was, in addition, often more effective a speaker in public than in parliament, and his successes at such gatherings, and in his radio broadcasts, was one of the reasons for his consistently higher standing and popularity outside Westminster than within.

32. Hilton Young's draft autobiography, c. 1959, Kennet MSS $82 / 1 / 49-50$. 
There is no doubt also that Baldwin had great personal charm and attractiveness, and the complimentary descriptions of his character, from friend and foe alike, are too frequent to be ignored. His admirers were not blinded to his defects, but rather cherished him in spite of them. Dawson wrote of Baldwin, "I always find myself agreeing with all his general views.... I still think that, though far from ideal as a galvanic leader, he is a way ahead of most possible successors."33 His most important ability was his capacity to inspire trust; Lloyd George and Churchill might be more fun, and respected for gifts of administration and skill in debate, but neither was ever trusted in the way in which Baldwin was. There seems little evidence to discount Bridgeman's assertion that "of his honesty and sincerity I think nobody ever had any doubts".34 The combination of these attributes allowed Baldwin to survive whilst exasperating or disappointing one colleague after another. Amery later wrote that:

Baldwin was a personality, with a breadth of outlook, a tolerance and a warm humanity which commanded the admiration, as well as the affection, of those who chafed under the weakness of his leadership.

33. Dawson to Irwin, 17 June 1930, Dawson MSS.

34. Bridgeman journal, volume 2, p. 181.

35. L. S. Amery, My Political Life (1953), volume II, p. 398 . 
In one sense Baldwin could be seen to embody in his own person the traditional virtues of a gentleman. Thus he appeared to the backbench MP Waldron Smithers:

to my way of thinking, Mr. Baldwin stands for all that is vital, fundamental, and true for the progress and development of Civilisation not only in the Empire but all over the world.

On several occasions this gave him considerable power over retaining the loyalty of dissident colleagues: in the case of Amery, of Neville Chamberlain, and by the silent manner of his departure, in the resignation of salisbury as leader of the party in the House of Lords in 1931. Because it was widely recognised, it also gave Baldwin that crucial appeal across party boundaries to erstwhile opponents and to the uncomitted electorate at large. He was clearly seen as the Conservative Party's greatest electoral asset, and, though not always the favourite of the party activists of the constituencies, had considerable appeal to the important section of 'middle opinion', especially in the north of England and in Scotland. It was this appeal which the party attempted to exploit with its slogan of "Trust Baldwin" in the 1929 election campaign, and defeat on that occasion did not undermine estimation of the value of his presence as party leader in the election any more than did churchill's defeat in 1945 undermine his.

36. Smithers to Salisbury, 19 August 1930, Salisbury MSS, $S(4) 136 / 148$. 
Baldwin was perhaps a better political tactician than has sometimes been allowed, though it has been correctly suggested that the excessive attribution of cunning and tradecraft by defeated opponents such as Beaverbrook or Churchill is more a reflection of their own face-saving than a true estimate of his abilities. However, he possessed one attribute sufficiently rare in a political leader to be worthy of comment, and that was patience. Together with his refusal to be pushed out of office, which was as much the product of his ability to ignore attacks from his party that were much more humiliating than those which had caused Balfour to decide to quit in 1911, this combination gave his approach the character of the "waiting game". This was often confused, due to inactivity, with playing a "deep game", but was in fact more often the politios of drift, of "wait and see".

Baldwin's position during the party crisis was buttressed by two external factors, also sources of strength which he exploited to the full. The first of these was the problem of the lack of a suitable successor, or indeed of anyone who was both acceptable and willing to take up what appeared at that time to be a crown of thorns; particularly if to do so involved paying homage to the press lords and receiving the crown from their tarnished hands. By the time a successor had begun to emerge, in the person of Neville Chamberlain, in April to June, 1931, the question was no longer of immediate significance. The sefond point is the more essential. The 
events of the party crisis of 1929-1931 are in fact a classic example of the powerful position, especially in defence, of the leader of the Conservative Party, under anything short of all-out revolt. The long period of dissension under Balfour was evidence in fact of the strength of the position, and both Balfour in 1911 and perhaps to a slightly lesser extent, Austen Chamberlain in 1922, only retired from the leadership because they were not willing to continue in it, not because they were not able to do so. There existed no mechanism for the formal deposition of the party leader, and the constraints of the deeply ingrained tradition of veneration of the leader and loyalty to his person made rebellion difficult indeed. This was even more the case if the leader made efforts to divide the opposition, to appease at least some of the sections of it, and to give ground without losing face. A high-minded leader, committed unswervingly to a principle or policy, or obsessed with his personal honour, was more likely to decide for resignation. Baldwin came close to doing so, but chose instead a careful mixture of concession and 'principled' stubborness, which saw him through a series of holding operations against a rising tide of dissatisfaction. If appeasement was one of Baldwin's themes, then perhaps its most successful use was in the appeasement of the party during this period of crisis. 
'

, 


\section{CHAPTER ONE}

\section{The Shock of Defeat: May to August 1929}

After four and a half years in office since winning the general election of october 1924, Baldwin's Conservative government went to the polls on 30 May 1929. The party platform was based more on extoling the achievements of the previous term in office than in any specific proposals for the future. Combined with this attitude of relying on proven worth were warnings about the quack nature of the remedies for unemployment, the issue of the day, offered by both opposing parties. These themes were linked by the centre-piece of the Conservative campaign, which concentrated on the personal virtues and popularity of the Prime Minister, Stanley Baldwin, with posters showing him smoking the famous pipe under the slogans "Trust Baldwin" and "Safety First". Most Conservative politicians expected that the party would be returned to power, albeit with a reduced majority. In fact not only were they defeated in the election, but for the only time during the inter-war period the Conservative party ceased to be the largest single party in the House of Commons. Conservative MPs fell from the four hundred and nineteen elected in 1924 to the two hundred and sixty returned in 1929. The atmosphere was calm during the 1929 contest; indeed, there was almost a desire for excitement or changè for its own sake. One Conservative ex-cabinet minister commented afterwards: 
We fell because we were too good, and probably also, too boring. We had ceased to interest the Press and the people. It is very difficult for a Government at any rate for a sober-minded one - to continue to be interesting after four or five years.

The nature of the electoral contests in fact had proved most crucial. In 1929 the attempt of Lloyd George to revitalise the Liberal party during the previous three years was one of the principal causes of the Conservative defeat. Although Lloyd George failed in his main aim of securing the return of a large Liberal contingent, the high number of three-sided contests split the antiSocialist vote, usually to the disadvantage of the defending Conservative MP. Of the two hundred and sixty Conservative returns in 1929, for example, only thirty had straight fights with only one opponent. This, together with the fact that the Labour party was by now a less alarming prospect for government, and the swing of the pendulum effect often seen after a long.spell in office, produced the Conservative reverse. The election campaign, which was without any particular crisis, confirmed rather than distorted the prevailing picture. The result of the election was a hung parliament, as neither Labour nor Conservatives possessed an overall majority, with the Liberal group holding the balance. The circumstances differed very little from those of 1923 , except that on this occasion Labour was the largest of the three parties. 1. Worthington-Evans to Birdwood, 24 June 1929, Worthington-Evans MSS, Eng. Hist. c. 896, ff. 203-4. 
However, they could be voted out at any time, provided sufficient Liberals were willing to go into the Conservative lobby for that purpose. On the other hand, the Conservatives alone were powerless to bring about a dissolution, unless they could secure such Liberal allies.

The strength of the Conservative party lay in the English seats. Even in defeat in 1929 the Conservatives still held almost half of these: two hundred and twentyone of a total of four hundred and eighty-five. In Scotland the position was less strong; Conservatives sat for twenty of the seventy-one divisions, or just over one quarter, while they possessed only one of the thirty-five Welsh seats, and that was the semi-English county seat of Monmouth. Of the remaining seats, both categories for their different reasons were perhaps naturally biased towards Conservatism: the party holding ten of the twelve Ulster seats on the Unionist ticket, and eight of the University graduate elected places. The breakdown of Conservative strength within the English regions affords a revealing illustration of the geographic distribution of Conservatism. 


\begin{tabular}{|c|c|c|c|c|c|c|}
\hline \multirow[b]{2}{*}{ REGTON } & \multicolumn{3}{|c|}{ BOROUGH DIVISIONS } & \multicolumn{2}{|c|}{ COUNTY DIVISIONS } & \\
\hline & $\left\{\begin{array}{l}\text { No. of } \\
\text { Seats }\end{array}\right.$ & $\begin{array}{c}\text { No. of } \\
\text { Cons. Seats }\end{array}$ & $\begin{array}{l}\% \text { Cons. } \\
\text { Held }\end{array}$ & $\begin{array}{l}\text { No, of } \\
\text { Soats }\end{array}$ & $\begin{array}{c}\text { No. of } \\
\text { Cons. Seats }\end{array}$ & $\begin{array}{l}\% \text { Con } \\
\text { Held }\end{array}$ \\
\hline South East England. & 93 & 40 & 43 & 53 & 44 & 83 \\
\hline South West England & 20 & 9 & 45 & 43 & 33 & 76 \\
\hline Festern Counties & 7 & 3 & 43 & 20 & 12 & 60 \\
\hline Midland Counties & 42 & 9 & 21 & 30 & 16 & 53 \\
\hline Wel.sh Marches & - & - & - & 6 & 4 & 66 \\
\hline North East England & 38 & 6 & 16 & 37 & 10 & 27 \\
\hline North West England & 53 & 14 & 26 & 27 & 14 & 51 \\
\hline Border Counties & 8 & 2 & 25 & 8 & 5 & 62 \\
\hline ENGLAND Total: & 261 & 83 & 31 & 224 & 138 & 61 \\
\hline Scottish Lowlands & 28 & 8 & 29 & 24. & 4 & 16 \\
\hline Scottish Highlands & 5 & 1 & 20 & 14 & 7 & 50 \\
\hline SCOTIAND Total: & 33 & 9 & 27 & 38 & 11 & 29 \\
\hline South wa.les & 10 & 0 & 0 & 17 & 1 & 6 \\
\hline North Wales & 1 & 0 & 0 & 7 & 0 & 0 \\
\hline Total: & 11 & 0 & 0 & 24. & 1 & 4 \\
\hline OVERALI TOTAL: & 305 & 92 & 30 & 286 & 150 & 52 \\
\hline
\end{tabular}

For Definitions of the regions used, see Figure 2. 
For the purpose of the previous table and the following maps and tables, mainland Britain has been divided into a number of regions. The basis for this division has been a grouping of counties; no county has been placed in more than one region, for reasons of simplicity. The groupings reflect, so far as is possible to do on a broad canvas, the principal economic and social characteristics of the region. In addition, attention has been paid to contemporary opinion regarding the existence and composition of specific provincial areas. Two caveats should be borne in mind, however: first, that the number of parliamentary seats in each region varies widely, and second that the economic and social character of any county or region has to be over-simplified for the purpose of arriving at broadly 'agricultural'or 'industrial/residential' areas. Thus Yorkshire and Leicestershire are included in 'industrial' regions despite their rural areas, and several 'agricultural' regions contain industrial enclaves. The Border counties include Newcastle, for example.

Nevertheless, it is possible from these statistics to draw comparisons and conclusions about the political geography of Conservatism.

The regions fall into three types:

Industrial Midland Counties, North East England, North West England, South Wales, Scottish Lowlands

Residential South East England

Agricultural South West England, Eastern Counties, Welsh Marches, North Wales, Border Counties, Scottish Highlands 
The regions are defined as the following counties:

South East England

South West England

Eastern Counties

Midland Counties

Welsh Marches

North East England

North West England

Border Counties

Scottish Lowlands

Scottish Highlands

South Wales

North Wales
Bedfordshire, Buckinghamshire, Essex, Hertfordshire, Kent, London, Middlesex, Surrey, Sussex

Berkshire, Cornwall, Devon, Dorset, Gloucestershire, Hamphire, Isle of Wight, Oxfordshire, Somerset, Wiltshire

Cambridgeshire, Huntingdonshire, Isle of Ely, Lincolnshire, Rutland, Suffolk, Norfolk

Derbyshire, Leicestershire, Nor thamptonshire, Nottinghamshire, Staffordshire, Warwickshire, Worcestershire

Herefordshire, Shropshire

Durham, Yorkshire

Cheshire, Lancashire

Cumberland, Northumberland, Westmorland

Ayrshire, Berwickshire, Dunbarton, Dumfriess, Fife, Galloway, Haddington, Lanark, Linlithgow, Midlothian, Peebles, Renfrew, Roxburghshire, Selkirk, Stirling and Clackmannanshire

Aberdeenshire, Argyll, Banff, Caithness, Forfar, Inverness, Kincardine, Kinross, Moray, Nairn, Perthshire, Orkeney, Ross and Cromarty, Shetland, Sutherland

Brecon, Cardigan, Carmarthenshire, Glamorgan, Monmouthshire, Pembrokeshire, Radnorshire

A n g e l sey, Denbighshire, Caernarvonshire, Flintshire, Merionethshire, Montgomeryshire 
One striking feature was the strength of the party in the county constituencies. In 1929 the Conservatives lost ground heavily in the borough divisions, especially those of Midland and Northern towns, and it was in these areas that Labour gained its parliamentary lead. It was not, however, the case that the Conservatives were more popular in the countryside than in the towns. Although the DeRating Act. passed by the government near the end of its life went some way to appease irate agriculturalists, many were still profoundly disillusioned with the amount of assistance that they had actually received from the Baldwin administration. ${ }^{2}$ The difference in distribution of MPs was in fact the product of electoral factors, and in addition Conservatism in the boroughs had always had a weaker hold than in the county seats. The urban seats can be categorised broadly into two types: the suburban or residential middle class areas, which were mainly a phenomenon around the largest conurbations, in particular in the Home Counties, and which were almost invariably very safe Conservative seats; and the mixed urban areas, either of inner cities or of smaller towns, and which had either a predominance or an element of working class population. It was in the latter seats and in the semirural northern counties, that most of the casualties were

2. Many felt that what they gained on de-rating, they lost by Churchill's Petrol Tax: Horncastle CA, Exec., 22 october 1928. Further examples of agricultural dissatisfaction: Stafford CA, Exec., 15 Maroh 1929; Hitchin CA, AGM, 22 May 1928; West Dorset CA, Exec., 24 August 1927; Cirencester and Tewkesbury CA, AGM, 21 May 1927 . 
concentrated. The Conservatives also did badly in three other areas of England. Not surprisingly, in view of the 1926 strike, the mining seats were barren ground for Conservatism. 3 Equally, Labour did well in London, in the East End and along the river; although the middle class areas continued to display "almost immovable Conservatism", the party suffered defeats in the mixed boroughs of London, such as Islington, Hackney, Hammersmith, Fulham, and above all st. Pancras where all three seats went to Labour. ${ }^{4}$ The final area of poor performance was in the most depressed rural regions, vulnerable to a revitalised Liberal appeal and often with a strong Liberal tradition in their political past: the Cornish seats, and a substantial slice of the East Midlands.

A more significant indicator of the nature of the Conservative party in 1929 emerges from a regional, rather than typological, breakdown of the English seats into the three principal areas, taking boroughs and county divisions together:

3. Doncaster Chronicle, 7 June 1929; K. Dugdale, "Conservatives, Liberals, and Labour in Yorkshire 1918-1929", Sheffield University MA dissertation, 1976, p. 207.

4. The Times, 26 April 1929. 


\section{Figure 3}

REGTON

South East England

South West Eng:land

SOUTHERN REGTON

Fastern Counties

Midland Counties

Welsh Marches

MTDI_AND REGION

North Esst England

North West England

Bordex Counties

NORTHERN REGION

REGIONAL ANALYSIS OF CONSERVATIVE STRENGTH

NO. OF

SEATS

146

63

209

27

72

6

105

75

80

16

171
NO. OF
CONS. SEATS

84.

41

125

15

25

4

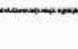

44

16

28

7
51

$\%$ OF SEATS

CONS. HELD

58

65

60

56

35

66

42

21

35

44

30 
SHOWN AS A PERCENTAGE OF THT TOTAI SEATS

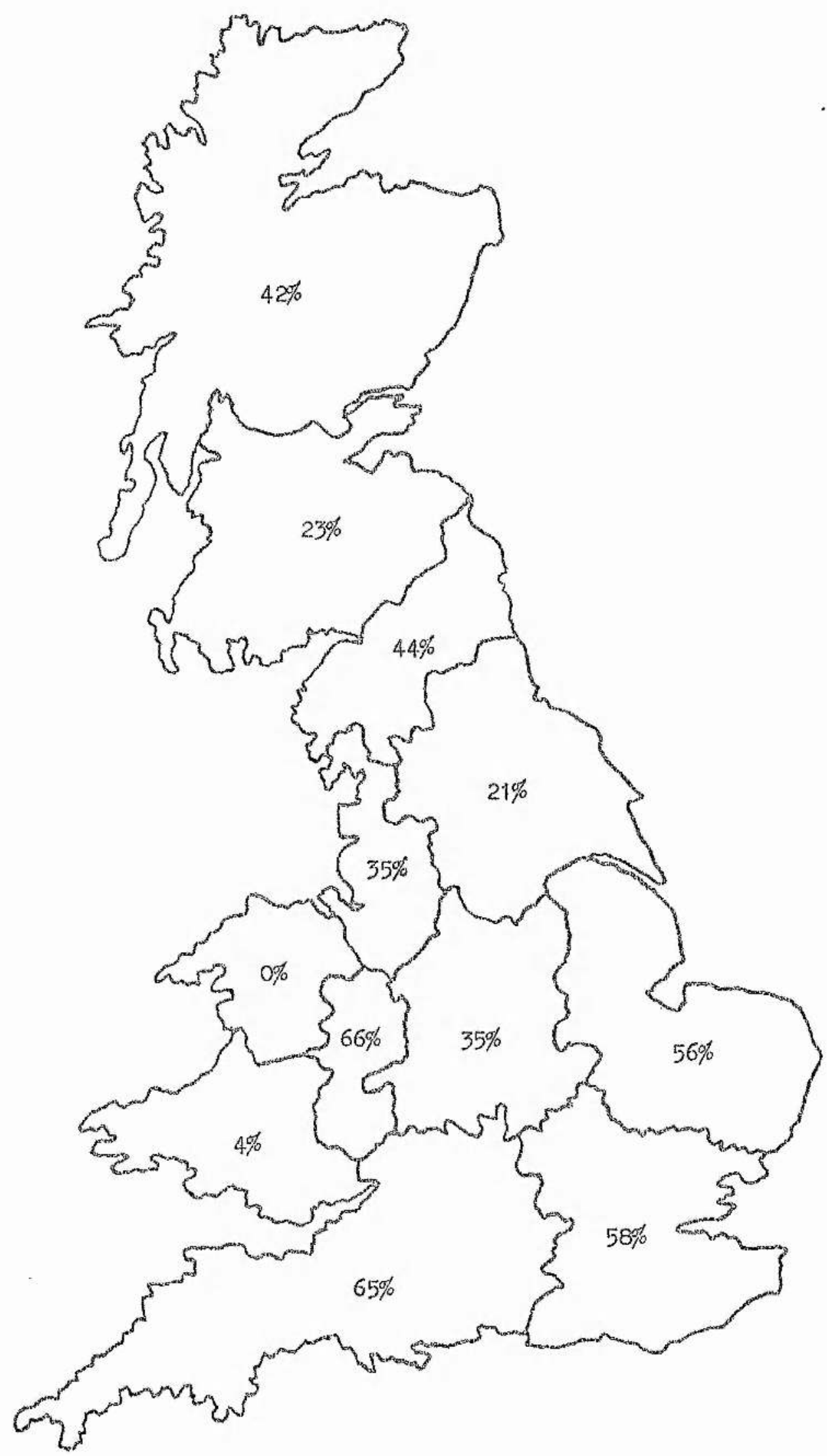




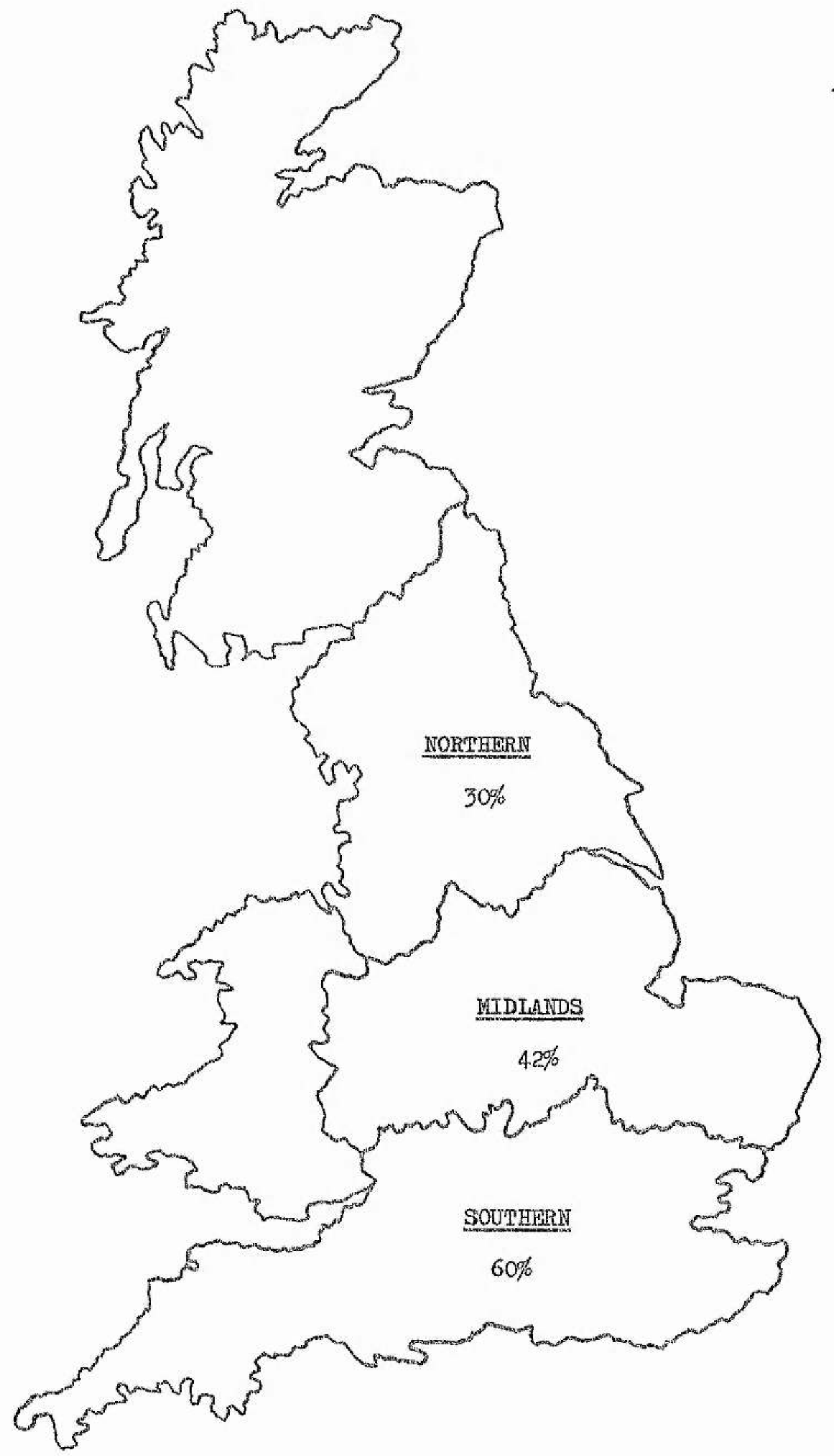


More noticeable even than the number of County members is the preponderance of the Conservative MPs who sat for southern English seats; very close to half the parliamentary party. In the Midlands the Conservative success rate was considerably lower, and in the North it was even more so. Indeed, the demographic alignment of the Conservative party goes some way towards supporting the 'two nations' interpretation of English society, North versus South. If the Conservative constituencies can be categorised at all, it would be first as English and southern, and only second as heavily biased towards the rural.

Furthermore, the bias towards rural seats was not reflected in the composition of the Members of the parliamentary party. On the contrary, many successful men from the business world sat for safer county seats, rather than their own urban constituencies. A local connection, although important and useful, especially in an area under the influence of a predominant socially prestigious family, was not essential to selection for even the safest of rural strongholds. The general attitudes and character of the candidate were equally important, and his ability to finance himself, his election expenses, and as much as half the running costs of the local Association, were even more so. The deputy chairman of the party wrote in 1930 that good seats were on sale and 
"up to the highest bidder". 5 In such circumstances, and as the balance of surplus wealth in general was tipping from the landed to the business element in society, so the occupational background of the parliamentary party adjusted in reflection of this. Men tended to stick to their own home county, though not necessarily to the constituency in which they made their livings. Even this parochialism was not completely uniform: forty Members sitting for English counties had had no prior connection at all with the county before their initial election for the seat. 6 . Indeed, men with backgrounds in law or business were increasingly coming to predominate over the landed element throughout the inter-war period. This was in part a result of the disintegration of the Liberal party, which had in the past drawn much support from law and business. An analysis of the occupational background of the Conservatives returned in 1929 breaks down as follows:

5. Memorandum on Selection of Candidates, Bowyer to Baldwin, 12 December 1930, Baldwin MSS, volume 48, ff. 187-192; see also comments of Headlam on putting in for selection for a safer seat, Headlam diary, 1930-31, passim. These comments are underlined by conclusions from a survey of extant CA records, 19181945, and in particular by: Reigate CA, Exec., 25 February 1929; Chelmsford CA, Council, 26 October 1926; Uxbridge, Exec., 17 November 1923; whilst the problems found by poor seats in securing a candidate are underlined by the example of Bradford South CA, Exec., 24 June 1926.

6. J. M. McEwen, "The Unionist and Conservative Members of Parliament 1914-1939", University of London Ph. D. thesis, 1959, pp. 289-290. 
Figure 6

Occupational Background of Conservative MPs 1929

Landed

Army, Navy and Diplomatic

$14 \%\}$

$19 \%\}$

$33 \%$

$33 \%$

Business: Commercial and Financial 16\%

Business: Industrial

$16 \%\}$

$35 \%$

$32 \%$ ?

$67 \%$

Legal and Professional

$35 \%$

7

To simplify further, whilst only one-third of the parliamentary party came from the traditional backgrounds of land and services, two-thirds came into political life from the commercial, industrial, or professional worlds from the business sector. This transformation from the landed party of the late nineteenth century was further underlined by the fact that only forty (fifteen per cent) of the MPs' parliamentary experience stretched back before 1914.8

This is certainly not to suggest that the social class of Conservative MPs was changing; rather, it illustrates the ability of the upper classes to accommodate newer sources of wealth within themselves. Fifty-nine Members were related to the peerage, and of these no less than thirteen were heirs to seats in the upper house. Another indicator of social class was the fact that one hundred and thirty-four of the MPs had attended one of the better-known public schools. Equally, one hundred and seventeen had attended either oxford or 7. Ibid., pp. 305-306.

8. Ibid., p. 283. 
Cambridge Universities, and many others had passed through the naval colleges or Sandhurst. ${ }^{9}$ Clearly the majority of the business element were not so much self-mademen, as men building upon the financial and social achievements of previous generations of their families.

If the changes in the occupational composition of the party were continuing as an undercurrent throughout the inter-war period, the defeat of 1929 had had a moredirect impact in changing the politioal complexion of the party. Broadly speaking, the Diehard, or right-wing, element tended to sit for the safer southern seats. These by their nature tended to be more vigorous and insular in their visceral Conservatism, having no need for tactical compromises to other powerful groups of local opinion. Thus the Diehards were on the one hand insulated from the changing social, ideological, and political nature of the country, and yet on the other hand were protected from the direct electoral consequences of these. The majority of such MPs were also protectionists of varying degrees of commitment, and the landed element figures unusually largely amongst them. Protection was a policy unpopular in many regions, but it was not without attraction to the richer agricultural regions of southern England, who were in direct competition with continental growers of fruit and vegetables, with Argentine beef, or with North American"grain. It was also attractive to the elderly 9. Loc. cit. 
Iiving on fixed investments in the solidly Conservative seaside. resorts: both were areas of strong Diehard support. On the other hand, the left or moderate wings of the party, who may have tempered their convictions with electoral expediency, suffered especially badly in the reverse of the election, and many of the so-called 'YMCA' group were not returned to the new parliament, as they tended to represent the northern and marginal seats in which the losses were concentrated. Thus, while the balance of British politics moved to the left with the return of a popular Labour government, at the same time the parliamentary representation of the Conservative party shifted rightward, a potentially dangerous situation for its future prospects. It has been estimated that the Diehard wing, through suffering proportionately fewer losses, rose in composition in the House of Commons from one-seventh of the party to one-fifth. ${ }^{10}$ In addition, their views gained influence both from the absence of the vocal rising young moderates, and from the fact that the circumstances of the defeat seemed to confirm their opinions. The tradition of local autonomy of constituencies from outside interference, coupled of ten with a financial dependence of the same associations upon the Member or his family, and the personal wealth and social eminence of many Diehards, prevented the imposition of effective party discipline. Neither the Central office nor the Whips had any meaningful sanctions with which they 10. Ramsden, op. cit., p. 298. 
could threaten the safer constituencies and so prevent the return of Diehard MPs. ${ }^{1}$ Their opinion was only of significance to those seeking office or honours, and it was a part of the world view of most Diehards that they eschewed any such ambitions. Most were concerned only to do what they considered to be their duty as diligent backbenchers, and were often rounding of $f$ career of achievement in another splere of life. As an alternative method of control to formal discipline, Conservative leaders had always relied upon the ingrained loyalty that was given by the party to the leader. However, this loyalty was conditional upon there existing a minimum of trust and confidence in the leadership, and the experience of Austen Chamberlain in 1922 had demonstrated that it could be stretched to breaking point.

However, whilst continually aware of the need to carry his existing party with him, Baldwin could not afford to simply pander to their prejudices if the party was to hope to return to power. Whilst he had one eye on the level of tolerance of the Diehards, he had to have the other on the political temperature of the northern and marginal seats lost in 1929, and which must be regained if the Conservatives were again to win a governing majority. Balancing these two conflicting forces produced many of the problems of the following two years.

\footnotetext{
* * * * *

11. J. Ramsden, "The Organisation of the Conservative and Unionist Party in Britain, 1910-1930", Oxford University D. Phil. thesis, 1975, pp. 158-159.
} 
The immediate decision that faced Baldwin after the election returns were in was which response to make to the ambiguous parliamentary position. It is a measure of the adaptability of the active politioian that the greater Labour successes of 1929 did not produce a parallel reaction to the aftermath of the 1923 election. The frantic searching for stunts to forestall a MacDonald ministry was not repeated, and the mood of incipient crisis was also missing. The absence of revolutionary peril brought about an important political consequence, in that it sharply reduced the attractiveness of a return to coalitionism. No figure of cabinet stature in 1929 sought such a deal in the short term, whatever his ideas about co-operation in the future. Indeed, amongst backbench MPs and peers, hostility to any such combination was violent and overwhelming. ${ }^{12}$ An alternative possibility was that of repeating the strategy of 1923, by meeting parliament as a government, and thus requiring the Liberals to foresake the fence and choose sides, it being expected that as on the previous occasion, they would opt for Labour, and in the process alienate the many antiSocialist Liberal voters. A gloss was put on this plan by Neville Chamberlain and L. S. Amery, who desired to turn

12. Duke of Buccleuch to Salisbury, 2 June 1929, Salisbury MSS S(4) 130/ff. 45-46; Gwynne to Baldwin, 31 May 1929; Colfox to Baldwin, 1 June 1929; OrmesbyGore to Baldwin, 2 June 1929, Baldwin MSS, volume 36 , ff. 102, 60, 218-219. 
the strategem further to advantage by deliberately riding for a fall on a strong protectionist platform, in order to raise the morale of the party at large. 13

Baldwin mulled over the advice he was receiving by post and in person during 1 and 2 June. It appears that before anyone influenced him, other than perhaps his wife, his first instinct was for immediate resignation before parliament met. ${ }^{14}$ In fact, this was not inconsistent with the tenor of the advice he was weighing up; for it all assumed that the government would leave office, only the method of its doing so being a matter of debate. on 2 June Baldwin consulted two of his most valued advisors, Lord Salisbury, leader of the party in the House of Lords, and Geoffrey Dawson, editor of The Times. Salisbury, while taking no clear line, did not disagree with Baldwin; but Dawson was for holding on and meeting parliament. Baldwin, however, despite the doubts and nervousness the latter advice caused him, adhered to his original line, and on that afternoon aired his views to the king's private secretary in typical imagery:

He has been beaten, and in the true English spirit he accepts his defeat and, if he resigns, the Democracy in an equally British spirit will take of their hats

13. N. Chamberlain to Baldwin, 2 June 1929, ibid., ff. 210-211.

14. Dawson diary, 1 June 1929, in J. Wrench, Geoffrey $\frac{\text { Dawson }}{20} \frac{\text { and }}{192} \frac{\text { Our }}{9 .}$ Times (1955), p. 275; Whitehali Diary, 
to him as a good sportsman, who has had his run, been beaten, and takes his beating like a man. And, what is more important, this will count in his favour whenever the next general election takes place.

On 3 June two events swept away the last of Baldwin's hesitations over immediate resignation. The first of these was that, influenced by the Astors, Dawson's leader in The Times that morning swung towards that line. ${ }^{16}$ The second was a letter from Lord Derby, who was not only a powerful Conservative magnate in Lancashire, but was also unkindly though accuratiely characterised as a political weathercock, who wrote: "I hope there will be no question of hanging on to office, the country was appealed to and has given its decision... and we must accept it and accept it like good sportsmen without any protest". 17 Thus, at the cabinet meeting summoned for 5:00 p.m. that day, Baldwin took the initiative by stating firmly and clearly his preference for immediate resignation, in which he was supported by Winston Churchill, his Chancellor of the Exchequer, and their combined weight carried the day against the minority who favoured the 1923 strategy. 18

15. Memo by Lord Stamfordham, 2 June 1929, Royal Archives RAK 2223/30, in Hyde, op. cit., pp. 305-306.

16. Whitehall diary, 20 June 1929; Daily Express, 3 June 1929.

17. Derby to Baldwin, 3 June 1929, Baldwin MSS, volume 36 , f. 225 .

18. Amery diary, 3 June 1929. 
The Secretary of State for War, Sir Laming WorthingtonEvans, probably voiced the feelings of the majority, not only in his cricketing language, but above all in his desire not to needlessly force a Liberal-Labour alliance:

My own view may be summed up: the Conservatives have been bowled out: they have lost the match, and they must let somebody else take to the wickets. Moreover ... some co-operation with Liberals is desirable in the next election, then it would be bad policy to force the Liberals now to co-operate with the Socialists in turning out a Conservative government which was hanging on beyond its welcome.

In the summer months of 1929 Baldwin was uncertain as to which direction party policy should take, and was engaged in a lengthy process of mulling over the risks involved in alternative courses of action, so much so that to a committed and eager backbencher like Patrick Hannon, the result seemed to be a party at a standstill.20 Immediately after the election Baldwin, tired and probably glad to escape from office, seemed literally to have no ideas concerning the future. "He is clearly bored with the present situation... and has no very clear ideas as to what our policy should be", noted the former UnderSecretary Cuthbert Headlam after a luncheon conversation in mid-July.21 In such a position Baldwin's character

19. Worthington-Evans to Hall, 4 June 1929, WorthingtonEvans MSS, Eng. Hist., c.896, f. 197 .

20. Hannon to Beaverbrook, 31 July 1929, Beaverbrook MSS, C153.

21. Headlam diary, 18 July 1929. 
naturally led him, through both caution and an odd element of complacency, into doing nothing at all. A close friend, Lord Irwin, then Viceroy of India, wrote metaphorically: "I can well believe that his temperament leads him ... into encouraging himself to sit in the front row of the stalls while the play is being performed."22

As a politician Baldwin had always been particularly concerned with larger questions of political mood, of educating 'democracy', of constitutional issues, or of the appeasement of 1 abour. Thus, in testing the air after a personally unexpected election defeat, he was even more than usually concerned with politics in the broadest sense of the term. Irwin commented later on a conversation with Baldwin in summer 1929:

I remember him saying to me at Garrowby that it is not sufficiently realised that what we were at present fighting was not a programme, but an atmosphere, which no amount of promulgation of counter-programmes could affect. This could only be done by the hard teaching of experience.

Having sensed a new atmosphere, he sought to conform with it as far as possible, first by avoiding giving any hostages to fortune in the form of policy definitions, and second by deciding to let the Labour government have a fair run. Baldwin was receptive to Ramsay MacDonald's 22. Irwin to Davidson, 25 February 1930, in R. R. James,

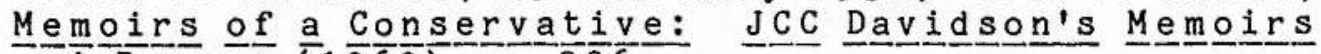
and Papers $(1969)$, p. 306 .

23. Loc. cit. 
appeal at the opening of parliament that issues be considered in the constructive and advisory manner of a Council of state, rather than in the usual adversarial roles of government and opposition. 24 This not only accorded with his own naturally unaggressive instincts, but also followed logically from the decision for immediate resignation taken after the election. In this appreciation of the popular mood Baldwin was by no means alone, as colleagues such as Neville Chamberlain and Sir Samuel Hoare also supported this line.25 Baldwin, however, more than most had made his straightforward and above-board approach his catchword, and he had a vested interest in ensuring that this reputation was not marred by the pulling of the rug from under the infant Labour government. Baldwin tolerated Churchill's feelers in the direction of a deal with Lloyd George in July, not because he had any desire to put the government out then - an end not even worked for by the combative Churchill - but because he envisaged a repeat of the 1924 situation, and considered it likely before the winter he would need Liberal votes in the lobbies to eject the government after it had either blundered badly, or revealed its true Socialist colours in despoliatory legislation, or

24. Baldwin's Statement on the Political Situation, 27 September 1929, Baldwin MSS, volume 56, ff. 161-167.

25. Hoare in Chelsea CA Newsletter, July 1929, Templewood MSS, volume VI/1; speeches by Chamberlain and Hoare, Gleanings and Memoranda, November 1929, p. 445; speech by Bailife-Hamilton, Bath CA, AGM, 24 October 1929 . 
preferably both. In fact it was unlikely that either Baldwin or his fellow anti-coalitionists of 1922 would have gone through with the idea of a plot with Lloyd George; he was merely testing the temperature of the waters. 26 However, Baldwin accepted as much as Churchill did the aim that, whatever the fate of the parliamentary Liberal party, Liberal voters in the country must not be stampeded into the Labour camp by the hasty adoption of a tariff programme, a tactic that would have

only one result - very likely final for our lifetime - namely a Lib-Lab block in some form or other and a Conservative right excluded from power.

This desire not to be caught wrong-footed on fiscal policy was reinforced by the rise in prestige of the Labour government during the summer and autumn of 1929. This continued popularity of the government, principally due to successes in foreign policy but assigned also by jaundiced opposition politicians to the lavish praise showered upon these by the largely Conservative press, led to the fear that MacDonald might try to capitalise on the situation by calling a second general election and going for a Labour working majority. The political indications suggested that, at least until December 1929, such a

26. N. to Ida Chamberlain, 29 June 1929, NC 18/1/660.

27. Churchill to Baldwin, 23, 26, 29 June 1929, Baldwin MSS, volume 51, ff. 85-86; volume 165, ff. 58-61; volume 164 , ff. $36-37$. 
tactic might well have paid dividends. 28 It was for this reason above all else that Baldwin clung to his centrist scheme, and the limitations of safeguarding. His political antennae were focused on the seats he needed to win back to regain a parliamentary majority - the marginals of the North and Midlands, whereas the wholehoggers were based in and encouraged by the attitudes of the safer southern seats. This was the essential reason for Baldwin's unwillingness to progress rapidly in the direction of tariff reform, for his political strategy was based on at the least raising no obstacles to the return of the decisive marginals to the Tory fold. Nevertheless, no party leader can afford to ignore for long his partisan stalwarts, and the need to find some formula that would appease the activists of the southern strongholds without alienation of other regions, was to remain Baldwin's major problem throughout the period in opposition. This question became acute in the light of the emerging critique over the causes of the defeat from the lower levels of the party in the aftermath of the election.

The leadershp's analysis had involved remarkably little retrospective soul-searching, and indeed was characterised by an air of complacency more appropriate to electoral victors than to the vanquished.

28. Lloyd George to Churchill, 16 0ctober 1929, Churchill MSS; N. to Mary Endicott Chamberlain, 1 June 1929, NC 1/20/1/47; C. Cook and J. Ramsden, eds., By-Elections in $\frac{\text { British }}{\text { cit., p. } 85 \text {. }}$ Politics (1973), pp. 75-76; Skidelsky, op. 
There was a clear preference for blaming the setback on events beyond the cabinet's control; on external factors as opposed to internal ones. Thus Lord Bridgeman, Hoare, and Worthington-Evans all settled for the swing of the pendulum effect as inevitable after a lengthy period of quiet government, fatalistically elevating it into an axiomatic law of nature.29 Neville Chamberlain improved on this by linking to it the insidious workings of Socialist propaganda; he also echoed the note of complacency predominant, when contemplating the postelection situation:

There is no conversion to socialism. It is merely the present discontents showing themselves in a desire for change.

and he could contemplate with detached calm the prospect that "the new govt. may make such blunders that before the two years are up the country will be glad to be rid of them." 30 Looking in a similar fashion to causes beyond the government's control, his half-brother Austen pinned the blame for the alienation of working class voters on the trade depression of the late 1920's.31 Hoare also went out of his way to deny that the controversial extension of the

29. Bridgeman journal, July 1929, volume II, p. 175; Chelsea CA Newsietter, Juiy 1929, op. cit.; Worthington-Evans to Birdwood, 24 June 1929, Worthington-Evans MSS, Eng. Hist. C896, ff. 203-204.

30. N. Chamberlain diary, 8 June 1929, NC $2 / 22$.

31. A. to Ida Chamberlain, 7 June 1929, AC 5/1/475. 
franchise in 1928 to the "flappers", women aged twenty-one to thirty, had contributed to the debacle. Even the single Cabinet Minister to lose his seat, Sir Arthur Steel-Maitland, not only agreed with Hoare, but also found nothing more significant to blame than his enforced absence from his constituency due to his duties as Minister of Labour. 32 As an adjunct to this 'act of God' syndrome, Baldwin and other anti-Coalitionist ministers also blamed the activities of Lloyd George and the intervention of Liberal candidates, again an entirely external event. On 31 May Baldwin informed Lord Stamfordham that the cause of his defeat was

the action of the Liberal Party, who have put up representatives in almost every constituency with no chance of winning, but taking away the votes which would have been given to the Conservatives.

The only slight notes of criticism were directed at two leading ex-Coalitionists. Austen Chamberlain, who had offended by announcing his continuation as Foreign Secretary after the election despite infirmity and the considerable unpopularity of his policies, and Churchill for the whole slant of his fiscal policy at the Exchequer. 34 The only member of the ousted Cabinet who 32. Steel-Maitland to Collier, 3 June 1929, SteelMaitland MSS, SRO GD193/251/4.

33. Memo of conversation by Stamfordham, RA.K 223/24, in Hydè, op. cit., p. 303 .

34. Bridgeman journal, July 1929, volume 2, pp. 173, 215. 
dissented from these comforting consolations was Amery, who had for many months prior to the election been deeply unhappy at the eschewal of anything hinting at tariff reform, such as positive proposals for wider safeguarding. For the moment, however, he kept his conclusions to himself, and at the final meeting of the Cabinet on 3 June "did not air any retrospective wisdom for my colleagues benefit." Thus "We all parted very happily, voting ourselves the best government there has ever been." 35 The complacency of the leadership on this occasion offers an interesting contrast with the aftermath of the previous defeat under Baldwin's leadership in 1923. On that occasion the constituencies, on the whole favourable to protection, did not blame the policy after defeat, although the circumstances surrounding it produced a bitter debate in the upper echelons. Now, with a defeat on the leadership's selected moderate policy, the roles were reversed with a vengence.

Initially the rank and file adopted an explanation that might be summed up as putting defeat down to 'Liberals and Lies'. This took the double-headed form of blaming the intervention of Liberal candidates splitting the anti-Socialist vote, and the accusation that not only the Liberals but also Labour had won votes by foul tactics. It was asserted that these had consisted of misrepresentations of the policies and record of the

35. Amery diary, 3 June 1929. 
Conservatives as well as a corrupt political auction conducted by both opponents. The latter meant, in Labour's case, bribery through offers of remunerative social welfare legislation, and in Lloyd George's the "We Can Conquer Unemployment" promise, both of which in Conservative eyes were knowingly fraudulent due to practical difficulties which were being ignored by their promoters. The party clearly needed to believe at first that it had been beaten by unfair means, rather than through any deficiency on its own part. Thus it was merely being more blunt that its leaders in fixing the cause on visible opponents rather than vague trends. This allowed the consoling view that they had preserved their honour: political honesty operated even at the price of defeat. In northern constituencies, where for electoral reasons demands for a positive protectionist policy were rare, this explanation continued to serve late into 1929. The Chairman of the Stockton Association declared: "We lost the election because we told the truth. We had to fight opponents who made rash promises throughout the length and breadth of the country."36

As the condition of shock wore of during and after July, this initial simplistic explanation underwent a gradual transformation into a position not only more complex, but also radically critical of the leadership. One contribution to the developing tendency to find fault 36. Stockton CA, December 3 1929; Cornwall Prov. Div., An. Report 1929; Yorkshire Prov. Area, An. Report 1929. 
with the actions of the late administration was the Central office inquisition of the local Associations. This had originated as a result of grumblings, originating from below, and heard in the demand for an inquest voiced by the influential Diehard backbencher Grant Morden in the 1922 Committee, and in the unanimous resolution mandating a questionnaire passed by the Council of the National Union on 2 July. 37 The execution of this was a typical piece of clumsiness on the part of J. C. C. Davidson, the Chairman of the party, in which his evident reluctance to pursue the matter, and desire to sweep the results under the carpet, almost certainly backfired by alienating the influential constituency members of the National Union Executive, such as Sir Charles Marston, who had pushed the idea. In fact, despite half-heartedly chasing responses in late 1929, the Committee set up to review the constituency replies does not seem to have produced any positive result. While there is no actual evidence that on this occasion Davidson bent the rules to take advantage of his office in the interests of his leader, it is not unlikely, for he was known to have done so on previous occasions. 38 His institutional position gave him every opportunity to put a spanner in the works; as Chairman of the Party he was also ex-officio Chairman of the National

37. P. Goodhart and U. Branston, The 192르, (1973), p. 39: NU Central council, July 2 19 $\frac{1}{9}$.

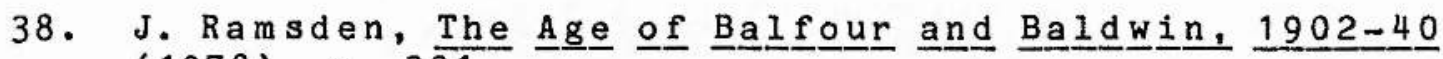
$(1978)$, p. 301 . 
Union, at both Executive and Council meetings, as well as being on the specific subcommittee in question. Furthermore, the questionnaire was transmitted via his own Central office, and it is hard to believe that he could not have received a better response if he had wished. In fact, by the end of october only two hundred and fiftyfive Associations had replied, and only a few more responses trickled in after this. Thus when, after the election, the interim and unpublished report was prepared in January 1930 its credibility was undermined by its being based on the views of only three hundred and fifteen Associations. This represented only fifty-three per cent of the five hundred and ninety which had run candidates at the election. 39 Nevertheless, the questionnaire produced several important results, and discussion of the replies in the meetings of local Associations cast light on a uniquely wide scale, into the opinions of the rank and file. Whilst several acknowledged local deficiencies, nearly all placed the emphasis on errors of policy and tactics at the national level, if only on the principle of shifting the blame:

It was agreed the defeat of the Conservative Party in the constituencies was primarily due to the mistakes of the Conservative Government and the Conservative Central office, combined with extravagant Socialist promises. In the case of West Wolverhampton it was felt that these conditions, and especially the intervention of a Liberal third candidate, were responsible for our defeat and that it must not be

39. NU Exec., 16 July, 3 October, 22 October 1929, 14 January 1930. 
attributed in any way either to the candidate or to the election Agent.

Figure 7

Constituency opinions on the Causes of the 1929 Defeat

\section{Note}

Fifty-three per cent of Constituency Associations responded to the Central office circular. However, as the original replies have been lost, and there survives no overall analysis of their content in the NU Minutes, local party opinion can only be traced through the local Association Minute Books. Many of the local Associations did not record the content of their reply; but the sample of surviving records was found to include a total of twenty-four constituencies, randomly scattered geographically and of different types, which recorded their reply. The following table is based upon these records, and consists of a percentage analysis by frequency of mention of any factor listed by more than one constituency. There is no apparent reason not to assume that this sample represents an accurate microcosm of the opinion of the party grassroots in general.

\section{Sources}

Accrington CA, Bath CA, Birmingham CA, Bradford CA, Camborne CA, Chelmsford CA, Denbighshire CA, Ealing CA, East Dorset CA, Glasgow CA, Gravesend CA, Guildford CA, Keighley CA, North Herefordshire CA, North oxfordshire CA, North West Wiltshire CA, Peterborough CA, Rochester and Chatham CA, Rutland and Stamford CA, South East Cornwall CA, Stockton CA, Torquay CA, Warwick CA, West Wolverhampton CA.

40. West Wolverhampton CA, Management Cttee., 26 June 1929 . 
Figure 7

$166 \%$ Criticism of the Derating Policy/Reassessment of Rates

2 58\% Intervention of a Liberal Candidate/Misrepresentation or False Promises by Liberal or Labour opponents

354 Absence of any 'Postive', i.e. Protectionist, Policy/Criticism of the Safety First Campaign strategy

4 33\% Criticism of having granted the 'Flapper' Vote

5 25\% Attacks on the Party by a hostile Press

6 17\% Failure of 1924-29 Government to economise and reduce local and national government expenditure

$7 \quad\{13 \%$ Apathy of Conservative supporters

Criticism of the Home Secretary, JoynsonHicks, in particular in connection with the Defence of the Realm Act

\{ $8 \%$ Failure of 1924-29 Government to reform the House of Lords

\{ $8 \%$ Absence of an Agricultural Policy

\{ $8 \%$ Criticism of the Petrol Tax

$8\{8 \%$ Criticism of Pensions Acts' anomalies

f $8 \%$ Hostility to the Local Government Act

f $8 \%$ Effects of the 'swing of the pendulum' 
Examination of the extant responses produces a strikingly cohesive picture. What emerges is an indictment of not only the specific acts, but also the basic political complexion and assumptions of Baldwin's government. The positive acts of social reform receive a unanimous thumbs-down: Derating, the Flapper Vote, Widows , Pensions, and the Local Government Act. In addition, grievances were noted in three areas close to the hearts of local activists: the failure of the Baldwin Ministry to use its majority to grasp the nettle of House of Lords reconstitution; to economise on government expenditure; or to advance in a protectionist direction; all these points had been the subject of previous constituency resolutions. 41 The negation on the last point in the general election was very unpopular, defeat confirming to many the folly of a lack of 'clear', i.e. Protectionist, policy. In general this played into the hands of those who asserted that Baldwin was not a true Conservative at all. Baldwin had taken considerable risks in his "New Departure" of 1924, and only success at the polls could have secured him invulnerability. It now seemed as if the chickens were coming home to roost. The North Oxfordshire association spoke for many in crisply replying to the questionnaire:

41. Yorkshire Prov. Area, Council, 10 December 1927 ; Ealing CA, Exec., 20 August, 30 November 1928; Rotherham CA, AGM, 30 April 1928; Chichester CA, GP Ctte.. 23 January 1928; Bath CA, Exec., 13 September 1927 ;. St. George's CA, Exec., 27 April 1928. 
That one of the primary causes of the defeat of the party and reduced majorities at the recent election was the actions of the Cabinet in riding roughshod over Public and Party opinion in the country, as expressed locally and at Conferences of the Party.

It was only one small step from verdicts like that above, to a full-scale demand for a greater say in the. policy of the party by the local Associations. 43 It speaks volumes for the dissatisfaction of the rank and file that such a demand should be openly voiced in the normally strictly hierarohical and authoritarian Conservative Party. The usual tactic for the leadership was to sidestep such demands and remove the original causes of the impetus behind them by adopting one or more of the favoured policies of the localities as a rallying flag. This facilitated the shelving of the constitutional question of intra-party democracy at a limited price and without allowing the constituencies any more power in practice. In one sense this had been the response of the 'alternative' leadership who placed themselves at the head of constituency feeling in 1921-22. If the grumbing was not defused in this way, it was likely to grow rather than diminish with time, and to pose a serious problem for the leadership's control of the party. Indeed, the posibility of a total disintegration was not so far removed as might be supposed, for the appeals of loyalty could only hold

42. North Oxfordshire CA, Exec., 24 September 1929.

43. West Midlands Area, GP Ctte., 18 October 1929. 
the party together for a limited period in the face of a fundamental divergence of attitude, as was demonstrated both in 1903-6 and 1918-22. This model of the progress of disillusionment with the distribution of power in the party can be seen from a case study of Ealing Conservative Association's attitudes during 1929. They responded to the questionnaire along orthodox lines in september, giving the causes of defeat as:

(1) the adoption of the slogan 'Safety First' (2) Hostile Press (3) De-Rating and Revaluation being misunderstood by the electors ... (4) sufficient prominence was not given to the policy of Safeguarding.

The lack of any clear lead from above during during the approach to the party conference led to the passing of two resolutions in October, one calling for Empire Unity and extension of safeguarding to be placed in the vanguard of the party programme, whilst the other called for "an assurance [that] in future the opinions of the party will be sought to a greater extent than in the past". 45 Conference did not resolve the problems, but rather stoked the flames, and by December the loss of faith in the leadership had progressed so far that the discussions included the gagging of speakers and the biased selection of motions at the conference, although procedure was in

44. Ealing CA, Exec., 13 September 1929.

45. Ibid., 11 October 1929. 
fact no different from any previous occasion. 46 However, the high tide of this demand for popular control was reached in October, when the National Union Executive debated an even more explicit resolution sent from the Lowestoft Association, which asked that "important questions of policy, before embodiment in the party programme, shall be submitted to the consideration of Constituency Associations". In the end the Executive rejected the idea, holding fast to the traditionalist view of the power and role of the party leader. ${ }^{4}$ Rank and file unrest also showed itself in two other ways. The first, and less serious, was the attempt by one of the more prominent MPs defeated in 1929 to organise a Defeated Candidates Association, and for this to be institutionally represented generally on all party committees and specifically on the Committee of Enquiry into the defeat. However, the organiser, J. T. C. MooreBrabazon, was still fully imbued with the attitudes of party loyalty, and felt unable to go ahead with his group without Baldwin's approval. Thus during the crucial period of July to November 1929 Baldwin was able to exploit this reluctance by preserving almost sphinx-like silence on the question; significantly, he only thawed to the idea after the Party Conference, though still

46. Ibid., 9 December 1929.

47. NU Exec., 22 0ctober 1929; Conference Resolutions, NU An. Report, 1929. 
ambiguously. 48 Baldwin still needed prodding to formally approve the idea in December, by which time the candidates were looking forward to the prospects of the next election rather than looking back in anger to the last. Thus they had a vested interest in moderation to regain marginal seats, and as a group tended thereafter to weigh in on the pro-Baldwin side at the party meetings of 1930. The second and more serious trend was the attacks on Baldwin's crony and nominee as Chairman, J. C. C. Davidson, both personally and through criticism of the constitutional functions and powers of his office, which were severely cut on rank and file initiative after the election. Davidson had done some good work as Chairman, but he had also alienated many important figures in often misguided controversies, and the sniping at him which continued during 1929 reflected this as well as the natural reaction to the co-author of a disastrous strategy.

The reaction to the election defeat of the constituency Associations and the backbench MPs had several important consequences in framing the party mood in the period before the 1929 conference. One noticeable feature was the bitter hostility to the Liberals, of which the remarks of the defeated Headlam during the election were a typical expression: "each day I feel more and more bitter against L[loyd] G[eorge]." Even more revealing of the attitudes of the new parliament towards any liaison

48. Moore-Brabazon to Baldwin, 28 November 1929, MooreBrabazon MSS. 
with that party for the purposes of an anti-socialist front was his comment a few days later on "the Liberals. How one dislikes them: far more than one dislikes the Socialists."49 Above all, however, the circumstances of the defeat played into the hands of the tariff reformers, apparently affording visible proof of their frequently aired critique of Baldwin's moderate politics.50 If defeat was bound to discredit the leaders who had drawn up the manifesto on which it had occured it was also bound to strengthen the hands of those who had opposed the failed strategy. Even the distribution of the losses could be argued to reinforce these views; as protection was always presented as a policy for prosperity, and thus a solution to unemployment, a strong line on safeguarding would have held the Northern and Midland industrial seats. As has been seen, this view found a ready audience in the local Associations, being the third most frequently cited cause of defeat [see figure 7]. This produced the increasing groundswell of resolutions from Associations demanding a new and stronger policy. One of the first examples of this also foreshadowed the developing North-South split of opinion: a resolution at the National Union Central Council asserting that

49. Headlam Diary, 11 and 25 May 1929.

50. Page Croft, Memorandum Upon Mr. Baldwin's Changes of Policy, November 1930, Croft MSS. 
in order to return the Conservative Party at the next election an industrial policy is necessary, and that the only such policy is the definite adoption of extensive Safeguarding of all the principle trades of the country, particularly Iron and Steel...

was carried despite the opposition of Sir John Haslam, representing the perenially Labour-held Lancashire seat of Westhoughton.51 As the balance of power in the parliamentary party had shifted decisively in favour of the southern areas, and the brake of the northern moderates had been removed, so it was from the south that the lead and pressure came, for the view that "the best hope of an early return of a Conservative Government lies in the whole-hearted advocacy of a definite policy of Empire development and the safeguarding of Industries". 52 This view, when linked by the Diehard wing of the party with criticism of the absence of vigorous attacks on the government from the front benches made for a popular and potentially dangerous combination.53 If Baldwin had been a more determined, more aggressive, or more effective leader of the opposition in the summer months of 1929, it is possible that these disappointments could have been assuaged without paying the price in terms of a change of policy or person. However, his weak and bipartisan stance served only to redouble dissatisfaction, and his failure to give a lead during the months of June and July 51. NU Central Council, 2 July 1929.

52. Wessèx Area, Res., NU Exec., 22 October 1929.

53. N. to Anne Chamberlain, 1 0ctober 1929, NC $1 / 26 / 408$. 
undermined the confidence of his colleagues, as did the unsuccessful first session of the new parliament. The first consequence of this was a drop in his own popularity and prestige.54 By the beginning of July Lord Beaverbrook, admittedly an unfriendly source, was able to claim "I have seen almost every Conservative ex-Cabinet Minister. I do not believe the Leader has a single sincere supporter."55 The second consequence was that other Conservtives, frustrated by the lack of movement, sought to grasp the initiative in an attempt to push forward party policy. Baldwin, according to Austen Chamberlain, "never moves of his own motion, but he can sometimes be set in motion by others", 56 while his halfbrother Neville likened Baldwin to a spinning top: "You must keep whipping him or he falls over". 57

The first two ex-Cabinet Ministers to break silence were Amery and Neville Chamberlain. Amery had been dissatisfied at the lack of a fiscal or imperial policy throughout the 1924-29 government, especially towards the end of it, and several times contemplated resignation, staying his hand only out of personal loyalty to and affection for Baldwin. Thus the defeat served only to confirm him in his analysis of the party's weakness:

54. N. Chamberlain Diary, 26 July 1929, NC $2 / 22$.

55. Beaverbrook to Rothermere, 3 July 1929, Beaverbrook MSS C284.

56. A. to Ida Chamberlain, 2 July 1931, AC 5/1/545.

57. N. to Hilda Chamberlain, 24 November 1929, NC $18 / 1 / 677$. 
The industrialised masses of this country must have a positive political creed to influence them. In Empire and Protection we have a creed which will appeal to the majority or certainly to the best among them .... We have now got to get back to a real fighting spirit, and ... to get together a small band who are out and out for a complete policy of Empire Preference.

Failing any clear lead from Baldwin, Amery resolved to use his freedom from the restraints of Cabinet collective responsibility when the cause of Empire Trade was debated in the House of Commons at the end of July. To set the ball rolling, Amery provocatively acknowledged divisions amongst the party leadership, and openly asserted his belief that the election had been lost through a lack of a clear and bold Conservative policy. It was not that he attempted to suggest any particular precise line; indeed, his speech was deliberately vague at that level, but the message was quite firm that in the new parliament the relevant divisions were between the two sets of fiscal opinion, rather than particular party labels.59 This move paralleled that of Neville Chamberlain, who was taking the initative in asserting that the party was no longer bound by the restrictive pledges of the election. On 4 July Chamberlain addressed the Empire Industries Association, and asserted that "the slate has been oleared". Amid

58. Amery to Page Croft, 6 June 1929, Croft MSS 1/2, f. AM 8 .

59. House of Commons Debates, 5th Series, volume 229, columns 739-741, 9 July 1929. 
cheers from the audience of backbench Conservative MPs, He declared "Now is the time for us to produce a new Imperial Policy." 60

Neither Chamberlain nor Amery at this stage indicated in any detail what he would like to see written upon such a clean slate. They were only trying to provoke discussion, not to pre-emptit. For this reason alone they were hostile to the fully fledged policy brought forward by Lord Beaverbrook with his Empire Free Trade campaign. Amery and Chamberlain stood aloof from this for three crucial reasons. The first of these was their sense of loyalty to Baldwin, for the extra-party nature of the Beaverbrook campaign was bound to cause confusion and problems, as was Beaverbrook's well known animus against Baldwin. In the second place they had considerable doubts about the long-term practicability of Beaverbrook's scheme, believing, possibly correctly, that it would not find favour in the Dominions even if adopted by a British government. The third and most crucial problem was that Beaverbrook's plan included the tax on imports of nonEmpire foodstuffs. This was seen by all shades of Conservative politicians as a potentially dangerous albatross indeed for the party to hang around its neck in the light of a possible election at any moment. There was little doubt in the summer of 1929 that such a policy would produce an upheaval on the scale of 1906.

60. Morning Post, 5 July 1929. 
Certainly neither Chamberlain nor Amery, the two most advanced leaders, wished to go as far as the food tax. 61 Indeed the actual policy advance they sought was quite small. What in fact they were attempting was to change the mood and outlook of the party at a more general level - an advance of rhetoric rather than substance. Both viewedit as urgent that the party should have a clear and distinctive policy, an imperial policy, and a popular policy with the rank and file, so far as electoral common sense would allow. In this sense they were taking part in the continuing and continual debate within the Conservative Party on what did, in fact, constitute practical politics. With committed protectionists before them, they believed that a bold and inspiring policy fed on itself, and would create its own momentum by enthusing the party rank and file, who would then carry the banner triumphantly to a wider audience. It was for these reasons that Amery and Chamberlain both talked in strident and striking terms about an advance in actual policy that was in fact quite minor. At most they were intending an extension of safeguarding, perhaps to include the iron and steel industries, but certainly not to extend it beyond the manufacturing sector. Thus their declarations were deliberately pitched in strong, if vague, language. 62 other leaders were more sceptical about the connection

61. Amery to Baldwin, 25 February 1930, Baldwin MSS, volume 31, ff. 44-48.

62. The Times, 8 November 1929. 
between the opinions of the party faithful and the attitudes of the floating, possibly ex-Liberal, voter. Baldwin in particular, having opted for a policy of caution in the election and still having lost, was unlikely to be receptive to the protectionist strategy. In the case of Amery in particular, his well known faddism on the imperial theme and his poor sense of timing undermined the impact of his actions on his colleagues. 63 The barometer of party policy responded to the debate between the two schools of opinion, and their changing perceptions of the attitudes of the ordinary voter. With the possible exception of Churchill, no Conservative leader had a philosophical or economic answer to protection as a policy, and indeed most paid it lip service as an ideal. The debate was in fact entirely about questions of timing and electoral practicability.

The uneasy relationship between public opinion and the desires of party activists was continually bedevilled by the complicating intervention of Lord Beaverbrook's campaign, which had also emerged in the political vacuum of the aftermath of electoral defeat. Lord Beaverbrook's original name was Max Aitken, and he had been born and brought up in Canada, were in early life he acquired a large fortune from business ventures and mergers. Now living in England, Beaverbrook had built a considerable press empire whioh was his abiding interest. Centred

63. Bridgeman Journal, volume 2, p. 199. 
around the Daily Express, his group also included the Sunday Express and the Evening Standard. Although he did not receive his peerage because of his newspapers, as had Lords Northcliffe and Rothermere before him, the fact that his power and influence were based upon his newspapers caused him to be grouped with them under the generic epithet of the 'Press Lords'. Any analysis of Beaverbrook's position would, however, be incomplete without conveying his significant background of activity in Conservative politics, and the wide range of contacts and friends he had made at all levels in the party, many of whom respected his motives, and always looked upon him, even in aberrant moments, as essentially a good Conservative. In fact it had been because of the attraction of Joseph Chamberlain's campaign for imperial economic union, a vision which fired Beaverbrook's enthusiasm, that he had come to England in the first place. He soon became the intimate friend of a leading front bench Conservative and tariff reformer, Andrew Bonar Law, through whose offices he was found a parliamentary seat at Ashton-under-Lyne, which he represented for five years. Law's accession to the leadership of the party, and the high-level world of manoeuvre amongst the Lloyd George Coalition during the war, brought Beaverbrook further to the centre of political power, albeit as an observer rather than a participant. In the immediate post-war period of Coalition government Beaverbrook 
oscillated from his involvement and intimacy with Lloyd George, to, after Law's first retirement in 1921, attacks upon it in the constituencies. After the fall of the Coalition, and the succession of Baldwin to the premiership on Law's final retirement in 1923, Beaverbrook found himself excluded from the inner counsels. Baldwin had always viewed the influence of the press magnates as one of the sordid and corrupting features of Lloyd George's regime, and a series of unfortunate incidents with the press during his first two governments only served to redouble his hostility to the popular tabloids. The result was that by 1929 it was well known that a personal and irremovable animus existed between the Press Lords, and in particular Lord Rothermere, and the party Leader which was fully reciprocated. The bad press the party believed it received as a result of this was prominent on the list of causes of the election defeat. 64 Though not a participant in the debates of the House of Lords, Beaverbrook was active in political life, mainly but not entirely through his newspapers. Two earlier ventures into active politics foreshadowed the Empire Free Trade Crusade. In 1923 Beaverbrook had waged war on the Conservative Government over a popular imperial issue close to his own heart - the failure to lift an embargo on Canadian cattle. He used his newspapers to attack the government in the same manner as the contemporary

64. West Midlands Area, Secretary's Report on the General. Election, GP Ctte., 18 October 1929. 
Rothermere-launched Anti-Waste League, by running independent candidates at by-elections. Beaverbrook was successful in defeating the Minister of Agriculture, Griffith-Boscawen, in his by-election at Mitcham. A second episode encouraged in Beaverbrook's mind the possibility of adding to such guerilla tactics personal intervention and advocacy on the platform, when he not only financially but also personally backed the independent Diehard Conservative Hall-Caine, when he defeated the former Liberal Coalition Chief Whip Guest.

Essentially Beaverbrook was seen as a maverick, but a genuine and sincere advocate of imperial unity through the economic programme of tariff reform, including food taxes in preference for Empire foodstuffs. Thus Beaverbrook was alienated from the Baldwin government both on personality and policy grounds by the time of the 1929 election, and "was clearly elated at Baldwin's failure". 65 He himself had not run imperial preference in the 1929 election in his papers, seeing little prospect of capturing the existing Conservative leadership for a programme they had explicitly ruled out as electorally impossible. Instead, he allowed his papers to drift, filling the empty space with a lightweight discussion of the problems of railwaytruck haulage, and admitted to his confidant and aide $R$.

65. Lookhart Diary, 30 May 1929; Beaverbrook to Birkenhead, 7 June 1929, Beaverbrook MSS C41. 
B. Lockhart that he was merely biding his time and sitting on the fence. 66

This situation was transformed by the balance of power after the election, and the visible search by many Conservatives for a clear line of policy provided Beaverbrook with a tempting opportunity to urge his own vision of imperial unity, a policy he knew would strike a chord with many other Conservatives. Beaverbrook's idea was simple in essence: the creation of a trading block consisting of Britain, her Dominions and Crown Colonies, which would join together in an imperial free trade zone by reducing their tariffs against each other, whilst raising a high protective tariff wall in common to deter competition from outside and provide an assured market. Thus Beaverbrook's policy would fulfill three distinct aims: it would encourage imperial solidarity through economic links; it would keep alive British industry and provide it with markets, thus reducing unemployment and the challenge of Socialism at home; and finally it would protect the British farmer from continual dumping of cheap surpluses of produce. Beaverbrook adopted the slogan of "Empire Free Trade" to describe this trading area, and claimed that his policy was a new departure:

our policy is not the same as that of Joe Chamberlain, though on ultimate ideals we are probably very close. He argued for Dominion

66. Lockhart Diary, 22 May 1929. 
Preferences, whereas I want to see Imperial Free Trade.

In fact this was mere hair-splitting, and Beaverbrook was simply refurbishing the old tariff reform banner of 1903. This was clear from his insistence that taxes on imported non-Empire foodstuffs were essential. He wanted "a tax on foreign wheat and meat. I hold the view that this tax is the keystone of any Imperial policy, and without it Empire Fiscal Union would be impossible."68 During the course of the Empire Crusade Beaverbrook's opinions and policies changed occasionally and sometimes in a contradictory manner. However, the insistence on facing the food tax was the most consistent and distinguishing feature of the Empire Crusade, and it was non-negotiable. Typically, however, Beaverbrook justified it by citing two conflicting reasons. The first was the fact that the food tax, which would give Dominion food exporters an assured protected market for their produce, was essential as a bargaining counter to achieve a reciprocal advantage for British industrial exports to the Empire. Thus

my complete familiarity with Dominion conditions makes it impossible for me to recede from the food

67. Beaverbrook to Caillard, 22 July 1929, Beaverbrook MSS, B94.

68. Beaverbrook to Melchett, 9 October 1929, ibid., C243. 
taxes. I know perfectly that it is the only thing we can give to Canada which is worth anything at all.

On the other hand, Beaverbrook wooed the disgruntled British agriculturalists, olaiming that his policy would protect their depressed industry. Thus Beaverbrook canvassed the branches of the National Farmers Union, asserting that "in a sentence, this policy is that of Protection for the farmers."70 Such claims were incompatible at a time when many British farmers were suffering more severely from competition from the Dominions than from the Continent or South America, but Beaverbrook did not realise this:

The keynote of the whole project is the tax on foreign wheat and meat coming into England. Without this tax, there is little hope of winning the farmers to our side .... the present system of preferential treatment must therefore be drastically altered in our favour.

There was a second and even more fundamental flaw in the Empire Free Trade programme. The nature of the Dominion economies had developed since Joseph Chamberlain's plan of 1903, and they possessed infant but potentially vital industrial bases which their tariff walls were designed to

69. Beaverbrook to Melohett, 22 November 1929, ibid., C243.

70. Circular from Beaverbrook to the NFU, 15 october 1929 , ibid., B99.

71. Beaverbrook to Elibank, 23 November 1929, ibid., C 126 . 
nurture and protect. Many experienced Conservative politicans had serious doubts as to whether the Dominions would in fact welcome opening their home markets to the full heat of British industrial competition, and it went without saying that as the Dominions could not be coerced, any such reluctance effectively negated the idea. Beaverbrook never successfully confronted this problem head-on.72 Instead, Beaverbrook preferred to conceftrate all his energies on securing the first part of his programme: winning the mother country for his policy, for in his view "Great Britain still has the hegemony of the Empire".73 This was one reason for his almost fanatical insistence on the food tax as the acid test of the new policy. ${ }^{4}$ In common with all other whole-hoggers, he believed that the "dear food" cry would in any case be used by opponents of the scheme, and would be easier to overcome if faced openly. But even here Beaverbrook often wished to have his cake and eat it; in this case almost literally by claiming that the food tax need not actually cost the British citizen any more:

As the Empire produces more wheat than it consumes it is absurd to suppose that the price of the loaf in this country will be raised when an import duty is levied on foreign wheat. The British housewife will not raise prices against herself by transferring her

72. Ibid.

73. Beaverbrook to Ruggles-Brise, 27 January 1930, ibid., B133.

74. Beaverbrook to Horne, 25 October 1929, ibid., C178. 
purchases of loaves from one shop to another, for that is all the change I propose amounts to.

Throughout, the economic programme of the Empire Crusade was conducted at this crude and simplistic level. It should never be forgotten that the economic justifications were purely adjustments to a party political propaganda campaign, and in this campaign slogans mattered more than any fine points of theory. Thus the assertion of originality and vitality was all-important:

Empire Free Trade is not Protection, or Fair Trade, or Tariff Reform, or Safeguarding, under a new alias. It is distinctly and definitely a new thing. All Empire products free of duty - no matter what they are. That has not been proposed before.

\section{6}

Beaverbrook's campaign was not without idealism, but it was a hardheaded idealism concerned with achieving practical results, and his enthusiasm and commitment showed itself in his pursuit of the chimera of Empire Free Trade. Thus, while Beaverbrook privately admitted the Crusade might take years to accomplish its goal, he always acted as if one more effort would secure total victory. 77

75. Beaverbrook to Bossom, 4 June 1930, ibid., B132.

76. Ibid.

77. Beaverbrook to Turton, 27 October 1929, ibid., B119. 
At heart Beaverbrook was a formidable propagandist, with a total commitment to his slogan:

If we are to be satisfied with preferences only, we might just as well not undertake the campaign at all. The only goal that I accept is Empire Free Trade. Anything else is only a means to that end.

His religious upbringing reinforced his political instincts, and the slogan became an article of faith that could not be qualified. "It is as well to fail in a righteous cause", he wrote.79

The pretext of an article in the M으므르므 므은, criticising Beaverbrook for his silence on the Empire during the General Election, provided the stimulus to action. To this Beaverbrook responded with two articles in the Sunday Expres $\underline{\text { Ex }}$, the first a call to arms for an imperial policy, the second unfolding Empire Free Trade for the first time. The latter article, appearing at the beginning of the Twickenham by-election campaign, was followed up by repeated articles in the Daily Express and Eveniㅡㅁㅗ Standard announcing the support of business figures such as Lord Melchett and Reginald McKenna.80 At first Beaverbrook's plan was merely to run a propaganda

78. Beaverbrook to Elibank, 23 November 1929, ibid., C126.

79. Beaverbrook to Melchett, 15 October 1929, ibid., C243.

80. Sunday Express, 30 June, 7 July 1929; Daily Express, 
campaign, perhaps along non-party lines, designed to rouse Liberal as well as Conservative support. 81 This quickly became an effort to capture the Conservative party, of which he was a semi-constitutional member, by traditional pressure-group techniques of propagandist persuasion. Initially, as at Twickenham, Beaverbrook sought to convert Members of Parliament, and before long the campaign changed from one of pressure by conversion to pressure by coercion. This transition was encouraged by the fact that while on the one hand the campaign failed to capture the parliamentary party, for despite many private assurances of support hardly any MPs came out publicly for Empire Free Trade in the face of party loyalty; on the other, it aroused an enthusiastic response from constituency rank and file members in southern England. The reaction of party leaders related to their political position, but even protectionist leaders such as Amery or the former Chancellor Sir Robert Horne could not swallow the food tax as a practical political proposition. Derby warned of Lancashire, "everybody is afraid of even breathing such a proposal in our part of the world".82 0thers more hostile to Beaverbrook viewed the campaign as merely a press stunt, designed to boost the circulation of his

81. Beaverbrook to Garvin, 12 July 1929, Beaverbrook MSS C140.

82. Derby to Beaverbrook, 20 November 1929, Derby MSS, 920 DER(17)/33. 
newspapers. 83 In addition to this, there was considerable suspicion, not limited entirely to the Baldwinite antipress circle, that the animus was personal hostility to the party leader. Neville Chamberlain probably spoke for most of the party in his mixed reception of Beaverbrook's policy, in acknowledging his sincerity and doubting the practicability: "His particular policy is obsolete, impracticable, and mischevious." 84 The initiatives of Amery and Neville Chamberlain, occuring simultaneously with the emergence of the militantly protectionist Empire Free Trade Campaign, caused considerable alarm in the parliamentary party, to both leaders and backbenches. 85

The already tense situation was further exacerbated by events surrounding the forthcoming Twickenham byelection. The vacancy had been caused by the elevation of Baldwin's Home Secretary, Sir William Joynson-Hicks, to the House of Lords as Viscount Brentford. The Twickenham constituency proved an ideal opportunity for the Empire Free Trade movement to illustrate its potential support at constituency level. Joynson-Hicks had been a traditionalist Tory of the old school, indeed almost a Diehard in outlook, and his seat was typical of the extremely safe Conservative London suburban belt.

83. Davidson to Tyrrell, 9 March 1930, in R. R. James, op. cit., pp. 324-325.

84. N. Chamberlain Diary, 26 July 1929, NC $2 / 22$.

85. A. to Hilda Chamberlain, 13 July 1929, AC 5/1/478. 
Furthermore, in a period when the vitality of much of the provincial press militated against the influence of Fleet Street in the provinces, it could be accurately suggested that the real influence of the mass circulation London dailies was metropolitan rather than national. How e there was any constituency in which the influence of the Daily Express and Daiㅡㅁㅡ Maiil were at their greatest, it would be the middle-class Home Counties suburbia of which Twickenham was typical. Not surprisingly, the candidate chosen to succeed Joynson-Hicks was a right-wing Conservative of strong imperialist views, and as such sympathetic to Beaverbrook's programme as well as desirous of his aid. Even before the formal announcement of his nomination, Sir John Ferguson asked Beaverbrook for support "because we both hold such strong views on Empire." 86 Beaverbrook now proceeded to apply pressure to Ferguson in order to force him to come out as openly as possible under the new banner, while for reasons of electoral tactics Ferguson was reluctant to burn too many bridges. However, in view of the considerable support for Beaverbrook among the activist rank and file of local Conservative Associations in seats such as Twickenham, even more than the supposed impact of his press propaganda, Ferguson could not afford to ignore the threat. Beaverbrook candidly informed him:

86. Ferguson to Beaverbrook, 2 July 1929, Beaverbrook MSS B 100 . 
For your private information, I may say that I thought somewhat of asking the local people at Twickenham if they would be willing to support an Independent candidate, not bound in allegiance to the Tory policy but advocating, instead, a policy of Free Trade within the Empire involving a tax on imports from elsewhere.

Ferguson was faced with little option but to pre-empt such a move by proving that he also was not bound in allegiance to the official policy, though he tried to hedge his bets and, while paying lip service to Empire Free Trade, he continually reiterated his loyalty to the party leader. He was reluctant to jump from the frying pan into the fire, especially in view of the fact that the swing of electoral opinion after the general election was still moving in Labour's direction. But the pressures on him were too strong, and the break came when, after a series of lurches in Beaverbrook's direction, Ferguson came out for food taxes in a speech on $16 \mathrm{Ju} 1 \mathrm{y} .88$ This Baldwin, already under pressure from alarmed free trade colleagues such as Salisbury and Northern wheel horses such as Derby, could not afford to ignore, as he had largely ignored Amery's faddist outburst. Baldwin had little alternative but to attempt to distance the party as much as possible from any identification with Ferguson's views. This he did by withdrawing official recognition and the assistance of Central office, and announcing this by a published

87. Beaverbrook to Ferguson, 3 July 1929, ibid.

88. Daily Express, 17 July 1929. 
letter to Ferguson, written in the tone of more in sorrow than in anger. 89 This move backfired, partly because the maladroit and clumsy Party Chairman, Davidson, was thought to be the motivating force behind what some MPs considered an over-reaction to Ferguson's offence. It produced considerable resentment amongst the right wing of the party, sympathetic by nature to Ferguson's politics, and many of whom had given a pledge to assist his $\therefore$ campaign. The ineffectiveness of party discipline was revealed when a deputation of these men, including respected long-serving backbenchers George Balfour, Sir Henry Page Croft and Sir Basil Peto, informed the Chief Whip that they had no intention of breaking their word: in the face of this, the Whips backed down.90

The consequence of the Twickenham campaign was thus to throw the party further into disarray, and the byelection provided a parade of Conservative disunity. Dissatisfaction on the back benches with Davidson's handling of events in particular was considerable, so much so, that the Diehard ring leaders requested Baldwin to convene a party meeting. The Diehards were far from being completely alienated from Baldwin personally, however, and it is clear that they wished to debate the policy of the party, and the mangement of the Central office, rather than the person of the leader. The memorial, drafted by 89. Baldwin to Ferguson, 23 July 1929, Baldwin MSS, volume 36 , ff. 268-269.

90. Evening Standard, 24 July 1929; presumably accurate as preserved as a record in the croft MSS. 
Sir John Gretton and signed by twenty-eight other back benchers, asserted that

our request for a party meeting arises entirely from our desire that these difficulties may be composed as soon as possible and that we may all work together confidently upon a definite policy .... we make our request in a spirit entirely friendly to yourself.

With the summer recess approaching, and buayed up by his customary self-confidence, Baldwin countered by agreeing to see a deputation, but ruling out a party meeting. In the event he also succeeded in postponing the deputation until late october, by which time the approach of the Annual Conference ruled out the need for a party meeting. In the event, the Twickenham result proved a severe disappointment to Beaverbrook, and confirmed the danger of a protectionist move by the party in the prevailing political climate of mid-summer 1929. Ferguson came close to losing this safe seat; he faced the same Liberal and Labour opponents as had Joynson-Hicks in May, but his majority plumeted from his predecessors' six thousand to a mere five hundred.

91. Gretton to Baldwin, 25 July 1929, Baldwin MSS, volume 164, ff. 66-67. 


\section{TWICKENHAM}

General Election

30 May 1929

Joynson-Hicks
Mason
Paterson
Conservative
Majority

Turnout

\begin{tabular}{lr} 
CON & 21087 \\
LAB & 15121 \\
LIB & 7246 \\
& \\
\hline
\end{tabular}

5966
By Election

8 August 1929

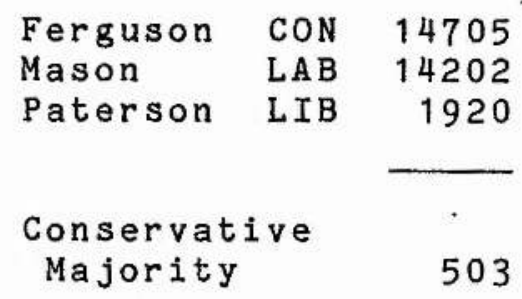

$50 \%$

Although the Liberal vote had undoubtedly been squeezed, little consolation could be drawn from this in view of the number of Conservative voters who had stayed at home, refusing to turn out for the protectionists. Beaverbrook's methods and policy at Twickenham, and their result, caused Amery and Chamberlain to back away. They still considered that food taxes, whilst in the long term desirable and even crucial, could only be advocated successfully after a long, slow programme of public education. Furthermore, both were committed to the Conservative Party as the only institution through which they believed their ideas could come to fruition, and thus they recoiled from any method of propaganda that resulted in damage to that party's electoral prospects. So, with critical results for the future, Beaverbrook was left to go it alone, unrestrained and unshackled. He failed to secure any experienced Conservative politicians tó dilute the leadership of his Crusade, despite repeated attempts 
to secure such a respectable figurehead, and nursed a sense of grievance and betrayal. He was left to operate outside the party, for the simple reason that at this point it was felt that his politics were more dangerous to it from within than without.

If the Twickenham result caused Cabinet-level tariff reformers unease, it seriously alarmed both the small free trade element, and even more important, the moderate centre of the party, who now proceeded to mount a counter attack. Churchill commented

The Twickenham election is a forerunner of what would happen in every constituency if we let ourselves be lured into it ... as fiscal matters may well become the issue of a General Election sprung at short notice.

92

But it was at the efforts of the ex-Ministers Amery and Chamberlain to commit the party leadership to a change of policy that most of the criticism and anger was directed. On 13 Ju1y Lord Salisbury wrote to Baldwin in alarmat the "two speeches by prominent ex-ministers within the last few days, both having the appearance of a return of Conservative official policy to Protection". He reported receiving many protests from MPs.93 Derby also appealed to him to reassert his leadership by a public disavowal of Amery's policy. To Derby, Amery's policy invoked the nightmare of a repetition of the 1923 tariff election

92. Churchill to his wife, 12 August 1929, Churchill MSS.

93. Salisbury to Baldwin, 13 July 1929, Baldwin MSS, volume 36 , ff. 261-262. 
disaster, when the party had been tricked into protection, on a decision taken by Baldwin, many thought, under Amery's influence. To quash this Derby requested a statement confirming that the pre-election policy enshrined in Baldwin's open letter to the Chief Whip, Eyres-Monsell, in August 1928, was still in force.94 There is no doubt that the fear of the electoral consequences, in the light of a possible general election at any time, was the cause of the alarm. Thus the backbench MP Lord Hartington wrote:

unless the enterprising Mr. Amery is checked before he goes much farther I do not think that [at the next election] we shall come back much more than two hundred strong. I for one should not stand if I had to fight on Protection.

Significantly, dissent spread far wider through the spectrum of the parliamentary party than merely the neofree traders; the moderate centre also took fright. This sentiment was echoed by a rising ex-Cabinet minister, Sir Samuel Hoare, who usually took care not to deviate from a centrist position. 96 Baldwin himself was always slow to change his views once he had settled into them. The conclusions he had arrived at in considering the electoral

94. Derby to Baldwin, 17 July 1929, Derby MSS 920 $\operatorname{DER}(17) / 33$.

95. Hartington to Salisbury, 11 July 1929, Salisbury MSS $S(4) 130 / 124-126$.

96. Hoare to Baldwin, 12 July 1929, Baldwin MSS, volume 36 , f. 260 . 
verdict placed a premium on moderation. He had also been swayed by the Austen Chamberlain-Churchill line. on the need not to alienate Liberal voters in the country, though he ruled out their corollary assumption of the utility of a deal with the parliamentary Liberals led by Lloyd George. Above all, Baldwin was conoerned to preserve party unity. The alliance of free traders, and moderates, together with the fears of the marginal seats, carried the day with Baldwin. He acceded to the demand for a showdown and summoned a Shadow Cabinet for the purpose. Neville Chamberlain noted:

everyone present except myself and Leo declared their determination to have nothing whatever to do with food taxes. They refused to consider making any new statement about policy lest the Liberals should take fright $\ldots$...

Loyalty to the leadership precluded Amery and Chamberlain from any further dissension, and Baldwin reassured Derby: "The situation is clear. Until such time as we put in our policy for the next election we stand on our [1928] policy." 98 Thus the opening round had gone definitely to the preservers of the statauㅗ qua 0 , the settlement arrived at in 1924. However, insofar as their motive for doing so was electoral expediency and not fiscal beliefs, should the national mood show signs of being more receptive to

97. N. to Ida Chamberlain, 13 July 1929, NC $18 / 1 / 661$.

98. Baldwin to Derby, 18 July 1929, Derby MSS, 920 $\operatorname{DER}(17) / 33$. 
tariffs, the protectionists' efforts to advance party policy were likely to find themselves pushing at an open door. Even in the moment of defeat at the Shadow Cabinet meeting, Neville Chamberlain had noted: "on the whole they were not averse to the idea that we should make Empire the starting point when we did come to consider the future". 99

99. N. to Ida Chamberlain, 13 July 1929, NC $18 / 1 / 661$. 
CHAPTER 2

\section{Pressures for Advance: September 1929 to February 1930}

In mid-July 1929 the first phase of the party crisis had ended with what appeared to be a complete success for the supporters of the statuㅗ으능 in fiscal policy. However, this achievement was swiftly eroded during the second half of 1929. The defenders of the moderate position failed to take any further action to shore up their position, and remained passive in the face of the emerging grassroots criticism of the causes of the election defeat. ${ }^{1}$ This inactivity was further exacerbated by two other factors: the hiatus in Conservative party activity at all levels customarily brought on by the summer recess, and the combination of both postelection exhaustion and an apathetic outlook which was itself partiy caused by the unattractive and undecided nature of the party's policies. ${ }^{2}$ As a result, neither the national nor the local party elites were exercising their usual firm grip upon the development of rank and file opinion. Of course, it was normal for political activity to die down during the holiday season; what was unusual was that this coincided, not with a period of political repose, but with an important stage in the evolution of grassroots attitudes. The absence of alternative

1. Hannon to Beaverbrook, 31 July 1929, Beaverbrook MSS C153.

2. Birmingham CA, Agent's Report, 11 october 1929; NW Wilts. CA, Exec., 14 June 1929. 
viewpoints allowed the criticisms voiced in the popular press to establish an ascendancy in the minds of many ordinary voters or members of the party. The average Conservative did not withdraw his attention from politics or the newspapers over the summer period, but rather he was more likely to have the leisure to absorb.his daily choice, and it became clear by the end of the recess that the empire free trade concept was attracting considerably increased support from the local rank and file. 3

After the setback at Twickenham, Beaverbrook himself had withdrawn from the public eye, relying upon the effectiveness of his newspaper propaganda to have the necessary impact on Conservative and popular opinion, and intending to re-open his campaign in October. ${ }^{4}$ However, his sudden reappearance on the political stage in that month was not the product of any such long-term planning, but was the result of a sudden alarm that he was about to be superceded in the direction and orchestration of Conservative imperial sentiment - a move to which his absence from the country had made him vulnerable. For Beaverbrook was not the only prominent figure in the business sector of the party to be considering pressure for advances in its imperial economic policy at this time. Lord Nuffield, Sir Abe Bailey, and the influential Lord

3. N. Chamberlain diary, 4 November 1929, NC $2 / 22$.

4. Beaverbrook to Bailey, 19 July 1929, Beaverbrook MSS B90. 
Melchett were also thinking along lines parallel to the original empire free trade proposals of July. This group, urged on by Amery, now looked likely not only to capture the public lead from Beaverbrook, but also, and even more seriously, to be watering down his policy. Melchett wrote to Beaverbrook on 8 october, inviting him to a dinner on 22 october organised by Bailey, which would appoint a committee to run their campaign, and enclosed a draft of the manifesto. At once Beaverbrook moved to outflank this initiative, selecting both on tactical grounds and by genuine conviction the acceptance of the food tax as the line of demarcation. In his reply he objected strongly to the omission of any reference to tariffs on food imports, declaring that "this tax is the keystone of any Imperial policy".5 During the following fortnight Beaverbrook prepared the next stage of his campaign, which was designed in both style and timing to recapture the limelight. On 22 october Bailey held his dinner, which was attended by Amery, Croft, George Lloyd, and Melchett; Beaverbrook was a noted absentee. ${ }^{6}$ His counterblast appeared two days later, when he produced his pamphlet manifesto of the Empire Crusade, entitled simply "Empire Free Trade". This was to be the opening fanfare in the progress of the campaign from the realms of newspaper

5. Melchett to Beaverbrook, 8 October 1929; Beaverbrook to Melchett, 9 October 1929, ibid., C243.

6. Daily Telegraph, 23 October 1929 . 
'stunt' into becoming an active propagandist organisation - though, not as yet, a political party. Beaverbrook was determined to try and capture the public in person. 7 As the food tax was to become his distinctive cry, Beaverbrook not unnaturally opened with an appeal to the body of opinion most likely to be favourable - the farmers of the South of England. 8 The first stage was the circulation of two proposals through the National Farmers' Union local branches. The first of these, dated 15 October 1929, set out the policy as being "in a sentence" that of "Protection for the Farmers"; the second, of 19 october, requested the sending of supportive resolutions to the NFU Executive. 9 The more critical second stage was to take the campaign to the public platform. From now on, Beaverbrook would not be content with newspaper propaganda alone - he was out to make the news itself. His first public appearance set the keynote, when on 280 ctober he addressed an audience of farmers at the sussex county town of Lewes, and nailed his colours to the mast on the food tax issue. 10 Neither Melchett nor Amery could bring himself to follow this lead, and thus the torch passed back to Beaverbrook's hands. The latter's renewed activity afforded a vivid contrast with the apathy evident

7. Beaverbrook to Rothermere, 24 october 1929 ; Beaverbrook to Moody, 23 October 1929, Beaverbrook MSS C284, B110.

8. Beaverbrook to Deeley, 20 October 1929, ibid., B97.

9. Copies in ibid., B99.

10. The Times, 29 October 1929. 
throughout the Conservative party; at the end of october Garvin wrote in The observer that the party "has no real soul and creed. It is weaker than at the General Election", and that Beaverbrook's campaign was "the only vivid, living, thing that is now going on in the Conservative Party". 11

At the same time as Beaverbrook recommenced his Crusade with a new air of stridency, the settlement of mid-JuIy was again challenged within the party leadership. At the end of the recess those who favoured advance were confirmed in their views by discovery of the extent of dissatisfaction at the lack of a 'clear' or 'forward' policy in the local Associations. Sensing that the climate of opinion within the party was slowly beginning to move towards protectionism, the pro-tariff element in the leadership sought to give both covert encouragement and restraining direction to this sentiment, to as great a degree as they felt to be consistent with personal loyalty to Baldwin. These public indicators boiled down to the assertion that some consideration of policy advance was inevitable, together with hints that it would take the form of a policy on imperial trade parallel to Beaverbrook's, but without going beyond a vague outline discussion. Typical of such moves was Neville

11. The observer, 27 October 1929. 
Chamberlain's speech at Gillingham on 23 october. 12 Although the contents of such speeches were not in themselves remarkable, taken together with the moves of Beaverbrook, Melchett and Bailey, they indicated that the solution arrived at by the shadow cabinet in mid-July had been temporary rather than permanent. That consensus proved incapable of holding up under sustained pressure, and as a result the party began to divide in a pattern which seemed to many to be ominously similar to the events which followed from the initial tariff reform campaign of 1903-1906.13 These parallels caused particular despondency to the Members and candidates in the northern constituencies: the MP for Lancaster glumly predicted the "recurrence of the campaign which proved so damaging to the Conservative party in pre-war days". 14

By the beginning of November 1929 the assumptions upon which the July statuㅗ quo had been based had begun to disappear. Most significantly, it became clear to Baldwin that continued adherence to the position of no advance on the general election policy was no longer a via media, preserving party unity, but would actively provoke dissension. At the same time, one important brake on the 12. The Times, 24 October 1929; see also The Times, 25 october, 13 November 1929; Lord Eustace Percy to Beaverbrook, n.d. but early November 1929 , Beaverbrook MSS B112.

13. Cecil to Salisbury, 24 February 1930, Cecil MSS, BM Add. MSS 51086, f. 82 .

14. Ramsbotham to Beaverbrook, 28 october 1929, Beaverbrook MSS B113. 
advance of policy was removed by the declining influence of Churohili during the summer and autumn months. Churchill had carried the day in July on the grounds that a tariff policy would face a Liberal-Labour alliance in defence of free trade at the polls, but by early November this fear was no longer paramount. The parilamentary Liberals were felt to have identified clearly with the Labour government and against the Conservative opposition in the House of Commons. This not only made an antiSocialist front unlikely, but also considerably reduced the dangerous prospect of a general election. At the same time the tide of popular approval of the Labour administration began to ebb as the inadequacy of its remedies for unemployment became apparent in late 1929. and the danger of a bid to achieve an all-out majority by Labour in the Commons receded. These changing circumstances removed the force of Churchill's arguments for conciliating Liberal opinion, and by December 1929 his line was overruled in the shadow cabinet.15 Like other experienced professional politioians, Churchill was conscious of the changing temperature, and he determined to swallow the inevitable. Churchill offered no objection to Baldwin's statement to the Party Conference; he had detected the beginnings of the shift in the foundations of British political life away from free trade.

15. Lane-Fox to Irwin, 22 December 1929, Halifax MSS, India office, Eur, C. 152/18/1/333; see chapter 6 . 
This was reinforced by the evidence of the resolutions from Conservative constituency associations during October 1929. Even the party Chairman, Davidson, was pressed to "formulate a definite and strong policy" by his own local Association. ${ }^{16}$ There were dangerous signs of the likelihood of a lead emerging from below on the model of 1922, if "a definite policy of Empire development" was not placed "in the forefront of the party programme". 17 The Kent Provincial Division typified rank and file unhappiness that the party had "no constructive programme which can be offered to the electorate as an alternative to socialism". ${ }^{8}$ In addition to this, Baldwin's leadership was being called into question on other grounds. A press statement which he had issued on 27 September had fallen flat, not only in the absence of a fiscal policy, but also for its muted and cautious criticisms of the Labour government. A crucial problem was Baldwin's lack of drive and assertiveness, and his failures as a leader in opposition. This was provoking criticisms not only from the lower echelons of the party, but also from the friendly press and rising younger

16. Hemel Hempstead CA, Council, 26 October 1929.

17. Wessex Area Res., NU Exec., 22 October 1929.

18. Metropolitan Area Res., NU Exec., 20 November 1929; Kent Provincial Div., AGM, copy in Salisbury MSS S(4) $131 / 107$. 
members of the leadership. 19 Baldwin's position at this time was further undermined by the debate provoked by the Irwin declaration, 20 and he badly needed to recoup his position and refürbish his Conservative credentials. This he was able partly to accomplish under the cover of a

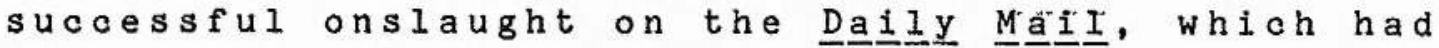
overreached itself in its criticism of Baldwin's approval of the Irwin declaration. Nevertheless, it was becoming increasingly apparent that Baldwin could only reassert his position by means of some advance in his fiscal policy, and thus hope also to restore unity. By the end of October 1929 the party was clearly rattled: "everywhere and on all sides I hear of depression, distrust, and despair, in our party" wrote Neville Chamberlain.21 In particular, the approaching annual party conference was likely to produce serious difficulties unless the leadership responded and pre-empted the position. Failing some lead in the direction demanded by many of the resolutions sent in for the agenda from the localities, there might even be "a great defection among the rank and file" who would "follow the lead of Beaverbrook".22 By

19. Baldwin's press statement, 27 September 1929, Baldwin MSS volume 56, ff. 161-167; N. to Hilda Chamberlain, 28. September, 13 October 1929, NC 18/1//671-672; Daily Telegraph, 29 October 1929.

20. See chapter 6 .

21. N. to Ida Chamberlain, 23 October 1929, NC 18/1/673.

22. Speaker's Report on Tour of Cornish and Devon Constituencies, to EIA headquarters, 22 0ctober 1929, copy in Beaverbrook MSS C153; NU Annual Conference Handbook, 1929. 
the middle of November 1929 pressure for a move forward was mounting from several quarters in the party, propelling the leadership reluctantly forward.23 It was the combination of all these various factors: the decline of Churchill, the removal of the fear of a snap dissolution or the need to conciliate the Liberals, the erosion of Baldwin's personal position through his lack of opposition vigour and the unpopular Irwin declaration, together with the pressures for advance from many sections of the party and the beginnings of a movement of opinion towards protection - all these, as much as the actual emergence of the Empire Free Trade Crusade itself, destroyed the assumptions of the July consensus, and made it necessary for Baldwin to make a move in response before the party conference scheduled for 21-22 November. Baldwin was thus now ready to make a limited and cautious move forward, still having one eye on the seats he needed to win back to form another administration, of the kind he had ruled out in July. Discussing the situation with Neville Chamberlain at the end of October, Baldwin "expressed the view that the new policy would have to take the form of an advance in safeguarding, but he didn't say in what the advance should consist". 24 such a cautious move was not intended to completely cut the ground from under Beaverbrook's feet, as Baldwin did not 23. EIA, Parliamentary Council, 13 November 1929.

24. N. to Hilda Chamberlain, 26 october 1929, NC $18 / 1 / 674$. 
dare to run the risk of agricultural protection. However, it was calculated to take the wind out of Beaverbrook's sails somewhat by recapturing lost ground amongst the party activists. The crucial point about Baldwin's new move was that, as with the settlement of July, it would once again attain a consensus. All that would be changed was, to a small extent, the policy and, to a much larger, the form of rhetoric which surrounded it which would now, in mid-November, produce a new consensus. As on the previous occasion, Baldwin's premier aim was the preservation of unity in the collective leadership, and once, again his line was that which gained the support of the largest majority of ex-Ministers, without driving the minority out into the wilderness. Across the spectrum of the leadership the picture was as follows: Amery, Neville Chamberlain and Austen Chamberlain preferred a bolder advance, and Steel-Maitland and perhaps Hoare leaned slightly in their direction; Davidson, Cunliffe-Lister and Bridgeman favoured Baldwin's electoral caution; Churchill, Worthington-Evans and Salisbury were reluctant to move at a11. Thus Baldwin adopted the median position, in an attempt to keep the leadership united behind him, and in the belief that any policy which achieved this would also be acceptable to the rank and file.

Baldwin did not wish to leave the success of his planned conference initiative to chance, but sought to prepare the ground by putting out feelers in early November 1929 in Beaverbrook's direction; he, like 
Neville Chamberlain, accepted that whilst not the root problem, Beaverbrook's campaign enormously complicated the political situation. Aware that he could only preserve the desired party unity by an advance that fell far short of Beaverbrook's platform, Baldwin did not expect to be able to negotiate a cessation of the crusaders' activities. Rather, he sought, by clothing his moderate advance in deceptively vigorous rhetoric, to induce Beaverbrook into a more 'oonstitutional' and less dangerous mode of activity. In this respect Baldwin was largely successful, and in response to his approaches Beaverbrook's activities passed through a moderated phase in the period immediately before and after the conference, which, considerabiy eased the pressures upon the leadership. The timing of the initiative was no coincidence, coming as it did on 30 ootober, hard on the heels of Beaverbrook's most divisive move, the open appeal to dissatisfied agriculturalists. The intermediaries were carefuliy chosen. With Baldwin's approval and encouragement the approach was made by Hoare, who was not only a personal friend of Beaverbrook's, but was also thought to lean towards the protectionist position. Beaverbrook was invited by Hoare for a confidential political discussion over dinner, with Neville Chamberlain making a third.25 Beaverbrook accepted, and the three men met on the evening of 4 November 1929. At first it seemed 25. Hoare to Beaverbrook, 30 October 1929, Beaverbrook MSS C 307. 
that the dinner had been a failure, despite hints from Chamberlain of "a great advance" to come in the party's imperial trade policy. 26 However, after reflecting on the discussion, Beaverbrook opted for compromise, for he by temperament preferred mergers or partnerships to direct confrontations. The following morning he telephoned Hoare, and enquired if the Conservatives had "meant business"; if they did, "he would be prepared to do a deal with us". 27

Beaverbrook also. responded.by translating his campaign onto a more orthodox line of approach; he ceased his appearances upon the public platform, and assumed the posture of a loyal Conservative respectfully urging his viewpoint on his leader. Thus on 7 November he addressed some eighty Conservative MPs of the backbench Imperial Affairs Committee, where he made a "deep impression ... by the very moderate and carefully reasoned way you presented the case for Empire Free Trade". 28 Beaverbrook then published a conciliatory article in the press on 10 November, appealing to Baldwin to take up his policy, and offering to efface himself if necessary. This olive branch, though the product of feelers indirectly initiated by Baldwin some ten days previously, now gave the leader an opportunity to respond directly. Thus on 11 November 26. N. Chamberlain diary, 4 November 1929, NC $2 / 22$.

27. Ibid., 5 November 1929.

28. Hannon to Beaverbrook, 8 November 1929, Hannon MSS $18 / 3$; The Times, 8 November 1929. 
Baldwin sent a short but cordial note to Beaverbrook, inviting him to a meeting at Baldwin's house on the following day, 29 at which Beaverbrook expounded his policy to Baldwin and Neville Chamberlain for two and a half hours. The meeting showed Baldwin at his most successfully sphinx-like, saying

of course he was not in a position to commithimself, but he gave the impression that on the whole he was convinced, and that he was merely considering political possibilities and expediencies.

This meeting was followed by contacts with several other members of the party leadership during the vital preconference period, all of which aimed to encourage Beaverbrook to remain on the 'constitutional' tack. 31 The most significant event of the pre-conference week provided further evidence that Beaverbrook had been tamed, temporarily at least. He moved further into the conventional political arena by making a rare venture into the House of Lords on 19 November 1929, to initiate a debate on the topic of empire free trade.32 The speech he delivered on this occasion was one of the most considered

29. Baldwin to Beaverbrook, Beaverbrook to Baldwin, 11 November 1929, Beaverbrook MSS C19.

30. N. Chamberlain diary, 12 November 1929, NC 2/22; N. to Ida Chamberlain, 17 November 1929, NC $18 / 1 / 675$.

31. A. to Ida Chamberlain, 18 November 1929, AC 5/1/487; Lockhart diary, 23-24 November 1929.

32. Parliamentary Debates, Lords, volume 75, col. 546562; Derby to Beaverbrook, 20 November 1929, Beaverbrook MSS C113. 
expositions that the empire free trade proposals ever received, but it was the forum rather than the policy that attracted the approval of the Conservative leadership.

Thus had the stage been set successfully for the party conference, and although the gathering was not without its tension between the leaders and their followers, the grassroots rebellion lacked effective leadership. The delegates directed their criticisms to two areas: first, the matter of intra-party democracy and organisation; and second, the demands for a clearer and bolder empire policy. When the conference opened on 21 November, the first nine resolutions on the agenda all dealt with complaints over organisation, and the ignoring of previous conference recommendations.33 However, criticism here was turned aside by concessions which went almost all the way to meet the complaints without actually infringing on the leader's powers of absolute discretion over policy. The strategy of pre-empting initiatives from the floor by this device of the report from the National Union Executive, the parallel appeal to let bygones be bygones, and a determined use of the platform's tactical advantage of command of the microphone, resulted in

33. NU Annual Report 1929, Conference resolutions in the name of Woodbridge CA, Sudbury CA, and Ealing CA are exapples of this, NU Annual Conference Handbook, 1929. An. indication of the depth of hostility was the decision of Walsall CA to instruct its delegates to support "the deposition of the Leader", principally due to bitterness over the 'Flapper' vote issue, Walsall CA, Emergency Ctte., 19 November 1929. 
comparatively smooth progress. 34 The second set of resolutions all dealt with party policy on safeguarding, tariffs, and the empire. All urged some kind of definition of intent, but it was noticeable that those sent in by the northern Associations were considerably less precise and advanced than those from the south. 35

On the evening of 21 November Baldwin addressed the assembled delegates at the Albert Hall. He commenced by blaming the election defeat on the promises made by his opponents, and followed this with a moderately successful attack on the government's record. Having reassured his audience on the matter of his fighting spirit, he then announced his acceptance of a resolution on empire trade and development passed that afternoon. Although this had been proposed by Page Croft, it was in fact a loose and undefined commitment well suited to Baldwin's tactical political purpose. This became apparent when, after pausing to pay a compliment to Beaverbrook, he took up the question of "the unity of our great Empire", and asserted: "to that task we must lay our hands, and to that task must our policy be framed"; this, however, must be "the task of your leaders, to which they will forthwith devote themselves".36 Although an advance was promised, caution

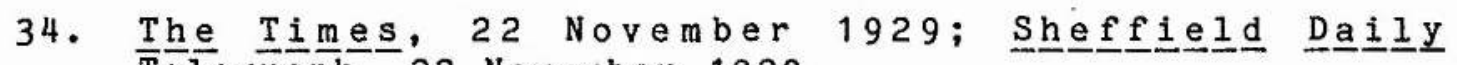
Telegraph, 22 November 1929.

35. NU Annual Report, 1929.

36. The Times, 22 November 1929. 
remained the keynote. The compliment to Beaverbrook and the acceptance of Croft's moderate and vague composite resolution served as a unifying gloss, a substitute for a policy rather than the introduction to one. In the following months the failure to follow through on the spirit of the Albert Hall speech was to completely undermine its achievement of party unity; but for the immediate moment Baldwin's oration produced - as he calculated - a favourable response from as wide a spectrum of party opinion as possible, by balancing between the instincts of the eager South and the cautious North. 37

\section{*}

The essential difference between the Albert Hall speech and the shadow cabinet compromise of July was the fact that whilst the latter had attempted to neutralise a dangerous topic for the foreseeable future, the November speech was much less ambitious. Its success lay not in what it laid down in concrete terms, for that was next to nothing, but rested on the fact that the speech promised serious attention to imperial economic policy, and therefore pointed to the unveiling of some such detailed programme in the near future. The achievement of a precarious unity at the party conference did not last

37. N. to Hilda Chamberlain, 24 November 1929, NC $18 / 1 / 677$; Derby to Baldwin, 22 November 1929, Derby MSS 920 DER ( 17 )/33; Moore-Brabazon to Beaverbrook, 22 November 1929, Moore-Brabazon MSS; Yorkshire Area, Council, 7 December 1929; Headlam diary, 22 November 1929; East Islington CA, Exec., 12 December 1929. 
because the promisory note at the Albert Hall was not redeemed with any hard cash. In spite of the keen hopes of the constituencies, it was neither followed up nor further defined as a policy.38 Whatever good effect Baldwin's speech at the Albert Hall had, it hardly outlasted the conference itself, and certainly had ebbed away by Christmas. With the benefit of hindsight, the defects of Baldwin's speech became more obvious than its merits, and it appeared to be lacking in any substance behind the rhetorical parade of imperial sentiment. 39 Thus by late January 1930 the same demands for a clear lead and for a precise definition of party policy that had surfaced in October were once again emerging. Towards the end of January Davidson was again pressurised by his local Association in almost exactly the same terms, dealing with "the complaint that the Conservative Party did not appear to have a policy with which to give a lead to its supporters", as he had been in late October 1929.40 Not only had the Albert Hall exercise been merely a question of buying time, but the breathing space acquired had been frittered away.

In addition, the entente with Beaverbrook proved shortived, not least because the efforts of the

38. West Lewisham CA Res., NU Exec., 14 January 1930.

39. N. Chamberlain diary, 8 December 1929, NC $2 / 22$.

40. Hemel Hempstead CA, Council, 25 January 1930. 
leadership to maintain close personal and political contact lapsed after the conference dispersed. Beaverbrook was left to his own devices, and, by nature restive and tempted to positive action, he came to feel during the month of December that he would have to promote the empire free trade policy himself once again. Throughout the period from November 1929 to February 1930 Beaverbrook's conception of the Empire Crusade oscillated between that of a propagandist pressure group, and that of a fully fledged political party. However, when Beaverbrook talked about a party, what he meant was pressure group tactics taken a stage further, to the activation of local branches in the constituencies, and the classic pressure group technique of threatening divisive candidatures, and running such at suitable byelections. His party would remain a single-issue party, and - despite occasional outbursts to the contrary - it was always his intention not to replace but to capture the Conservative party for his policy. This was the cause of his preoccupation with the hedgings of leading Conservatives, which caused much anxiety to those of his allies who sought to turn his attacks away to free trade Liberals and Labour. This concern was not excessive theological hairsplitting, but sound tactics: Beaverbrook felt that it was crucial to properly secure the Conservatives first, before turning his fire from this bastion onto the defenders of free trade. Although the process was erratic and even contradictory, there lies 
through these three months a clear theme of the evolution of the crusade from a propaganda committee to a mass political movement. Thus, on 2 December Beaverbrook outlined the Crusade's role as that of Conservative party pressure group, 41 but by February 1930 this had evolved closer and closer to an organised political party; local membership and subscriptions were solicited, and a Crusade committee, including Hannon, Lord Elibank, Sir Hugo Cunliffe-0wen, R. D. Blumenfeld, and C. A. McCurdy, was formed. ${ }^{42}$ The functions of this committee in reality were purely advisory; Beaverbrook remained kingpin of the Crusade. Furthermore, he returned to the public platform, and began to threaten to run candidates against the official line at by-elections. ${ }^{43}$ At the same time, he was moving to a formal alliance with Lord Rothermere, an alliance he sought for its additional press support, but which carried with it the implication of an assaut on the Conservative party. The alliance with Rothermere was to bring Beaverbrook many problems, but viewed as it was by Beaverbrook from the angle of circulation strength, the combined press lords' campaign which emerged at the end of 41. Beaverbrook to Cole, 2 December 1929, Beaverbrook MSS B138.

42. Elibank's 'Empire Free Trade' diary, November 1929May 1930, Elibank MSS SRO GD $32 / 25 / 74$, hereafter referred to as Elibank diary, f. 4; Beaverbrook to Melchett, 18 December 1929, Beaverbrook MSS C243; Draft Constitution of the Empire Crusade, copy in Hannon MSS $18 / 1$.

43. Beaverbrook to Lynn, 21 January 1930, Beaverbrook MSS B164. 
January 1930 was double jeopardy indeed for the party leaders.

The important point, however, is that the challenge from the Crusade was not the fundamental problem the party faced between December 1929 and February 1930; rather, it was only a symptom of the real problem, which was Baldwin's inaction and failure to provide effective leadership. This was the direct product of the dilemma which faced Baldwin in attempting to balance between the pressures upon him from different sections of the party for or against policy advance, pressures which were in fact irreconcilable. 44 The pressure to advance further came primarily from the constituencies, but it was echoed in the private urgings of Hoare and Neville Chamberlain, and the public utterances of Amery and Croft. 45 Many local Associations, especially in traditionally Conservative areas, were swept up by enthusiasm for the empire free trade policy as the most attractive option available, that "it might get our party out of the rut". 46 Other Associations were stirred into action through the negative stimulus of alarm at the prospect of a split in

44. T. Jones to E. Jones, 9 February 1930, Whitehall Diary.

45. N. Chamberlain diary, 8 December 1929, NC $2 / 22$.

46. Stigant to Salisbury, 26 February 1930, Salisbury MSS S(4). 133/183-4; Ashton CA to Beaverbrook., 27 January 1930, Beaverbrook MSS C12; Daventry CA Res., 27 January 1930, copy in ibid., B217; Gravesend CA, Exec., 13 December 1929; Uxbridge CA, Council, 7 December 1929. 
the party, and demanded a forward policy for reasons of self-defence, as a product of awareness of the apathy and low state of local morale. 47

opposition to advance was the product of two divergent schools of thought. The first of these were the traditional free-fooders, a declining force in the party during 1930. Of the leaders of this group, Churchill and Salisbury, though unhappy at the prospect, clearly anticipated as inevitable some extension of safeguarding. 48 If the resistance from this element wobbled under pressure, that of the second element was even more likely to do so. These were the politicians opposed not on principle but rather on pragmatic electoral grounds to what they conceived to be a dangerous policy, that "on any proposal involving food taxes no seat in the country is safe", and that "the dear food cry is devastating". 49 Whilst on the one hand their anxiety was much more widely representative of the majority feeling of MPs than was the opposition of the free-fooders, on the 47. Accrington CA, Exec., 21 January 1930; North Cornwall CA, Exec., 25 January 1930; Lincoln CA, Special Exec., 27 February 1930.

48. Salisbury's note of conversation with Baldwin, 28 January 1930 enclosed in Salisbury to Baldwin, 29 January 1930, BaIdwin MSS, volume 31, ff. 29-33; draft memo, Salisbury to Baldwin, February 1930, Salisbury MSS S(4) 133/118-121; list of free trade MPs enclosed in Beaverbrook to Rothermere, 19 February 1930, Beaverbrook MSS C284.

49. Bayford to Baldwin, 28 January 1930, Baldwin MSS volume 165, f. 18; Horne to Hughes, 3 March 1930, copy in Beaverbrook MSS B236; Cunliffe-Lister to Davidson, 3 January 1930, Davidson MSS. 
other hand it was even more open to the pressures of changing circumstances, and sensitive to the nuances of public and party opinion.

Baldwin's lethargy, and his optimism which was often construed as complacency, led him to rest for too long on the laurels of his success at the the Albert Hall.50 Baldwin never found it easy to come to decisions, especially when the issues were difficult but important, and the advice and opinions on them unclear. Neville Chamberlain noted that Baldwin "wavers backwards and forwards on the expediency according to the last person who has talked to him".51 Typically, the only thing Baldwin could decide upon was inaction. On 20 December he instructed Central office to tell constituency agents that no official discussion of the empire free trade policy should take place until further notice. However, the decision to take no decision was in fact the most dangerous of all. In particular, it caused the widespread impression that, far from going forward from the Albert Hall speech, Baldwin was drifting backwards from it. This was all the more serious when it was combined with his continued failure to attack the government with sufficient vigour or conviction. 52 The result of this situation, the 50. Gwynne to Northumberland, 18 December 1929, Gwynne MSS 21.

51. N. Chamberlain diary, 8 December 1929, NC 2/22; Bridgeman journal, volume. 2, pp. 181-183.

52. Hoare to N. Chamberlain, 24 December 1929, NC 7/11/22/9; Daily Telegraph, 5 February 1930. 
re-emergence of Beaverbrook's pressure group, the divisions of opinion within the leadership, and between leaders and followers, and the failure of Baldwin to provide a focal point, was a serious slump in the morale of the party. This was evident in the apathy commented on at local level, and even more so in the poor attendances of the Conservative Members in the House of Commons, a malaise consequent upon their loss of morale as an opposition, which in its turn provoked further alarm in the constituencies.53 This dissatisfaction with the parliamentary party made it all the easier for Beaverbrook's campaign to make headway. The real strength of the Empire Crusade was always that it reflected the disgruntled element of the rank and file of the looal Associations and of ordinary supporters; in periods when these groups were alienated from the parliamentary elite the Crusade became a suitable vehicle for their resentments, as much for any genuine support for Beaverbrook's fiscal policy. Beaverbrook himself recognised clearly where his strength came from: "My hold is on the public imagination, and not in the commons or Lords", he wrote. 54 However, he still tended to overrate the part played in this by his newspapers and his personal

53. Warwick and Leamington CA, Annual Report of Secretary, April 1930; St. George's CA, Exec., 19 December 1929; Guildford CA, Exec., 20 December 1929; Walsall CA, Emergency Ctte., 16 December 1929; East Islington CA, Exec., 27 January 1930.

54. Beaverbrook to Derby, 7 March 1930, Derby MSS 920 DER $(17) / 33$. 
platform oratory, and to underrate the part played by the negativism and weakness of Baldwin's leadership. Yet there was a direct relationship between the latter and the appeal of the Crusade, and the period of December 1929 to February 1930 saw not only the emergence of the crusade as a political force, but also the first serious stirrings of doubt about Baldwin's suitability as leader. 55

It was as a product of these circumstances that the party passed into a phase of incipient crisis in the last half of January 1930. Once again, the groundswell of national opinion was moving, slowly but perceptibly, away from orthodox free trade as unemployment continued to rise; in free trade Lancashire, which had long been taken as an indicator of the state of public opinion, the change was detected by Lord Derby - though the food tax proposal remained "the great obstacle".56 Although this development made the pressure on Baldwin greater, it also meant that it was easier for him to give ground to it, as soon as he accepted the need to do so. To this end he was urged on, not only by the call from the constituencies for a 'clear' lead, and by the speeches of committed protectionists, but also by similar advice from his own inner circle. On New Year's Day the Chairman of the party, Davidson, wrote to Baldwin suggesting that a

55. Malmesbury to Salisbury, 13 January 1930, Salsibury MSS S(4) 133/35-36.

56. Derby to Blumenfeld, 17. February 1930, Blumenfeld MSS D/Der. 45 . 
forthcoming address by the latter to MPs and candidates, to be held at the Coliseum on 5 February, would provide a suitable forum to "steal the thunder of both Rothermere and Beaverbrook in such a way as to prevent either of them attacking you". Whilst food taxes were still ruled out as politically impossible, Davidson was firm that "without going into too much detail the lead must be definite". 57 This advice was reinforced by the emerging signals of a crisis of confidence within the Conservative party. As opinion evolved, so the party's public position was left stranded high and dry, vulnerably exposed to Beaverbrook's saliies. Certainly, it was becoming olear that Beaverbrook, by giving expression to normally inarticulate rank and file sentiment, was making the running, and seemed to be capturing the party from the grassroots upwards. Gwynne told Baldwin frankly that Beaverbrook's strength was the fact that "his policy is endorsed secretly or open $3 y$ by $85 \%$ of the Conservative party". 58 Faced with this, it can hardly be surprising that MPs and their local Association elites became "rattled by what was going on in their constituencies".59 In addition, rather like corks impelled on the tide of opinion, some of the leading party protectionists came very close to at least

57. Davidson to Baldwin, 1 January 1930, Davidson MSS.

58. Gwynne to Baldwin, 21 February 1930, Gwynne MSS 15.

59. Davidson to Tyrrell, 9 March 1930, in James, op. cit., pp. $324-325$. 
fusion with, if not actual secession to, Beaverbrook's campaign. Croft, Hannon, and Amery advised him closely, and Sir Robert Horne, a former Conservative Chancellor highly respected in City circles, extended feelers to Beaverbrook. 60 An even more serious symptom was the reemergence of the Diehard group centred on Gretton; forty MPs signed the letter addressed by him to Baldwin on 27 January. Aware of the danger of being outflanked by the Crusaders, they demanded a clear statement of policy:

In the absence of such a declaration from you as Leader of the party, we are losing ground both in Parliament and in the country: many of our staunch supporters are looking elsewhere than to the Conservative party for the solution.

This was not a declaration of war on Baldwin; it did not seek to remove him, but rather to prod him into coming up to the mark. More precisely, the Diehards sought a return to Baldwin's own programme of insular protection of 1923 , which they held to represent "the true Conservative Economic policy". Thus, by the end of January the clear message was that it was vital for BaIdwin to take steps to reassert the authority of the leader, and to do so before the lower ranks of the party stampeded. 62 Baldwin was

60. Hannon to Beaverbrook, 12 and 13. December 1929 , Beaverbrook to Hannon, 14 December 1929, Beaverbrook MSS C 154.

61. Gretton Memorial, and list of signatories, to Baldwin, 27 January 1930, Baldwin MSS, volume 31, ff. 13-17.

62. Gwynne to Beaverbrook, 3 February 1930, Gwynne MSS 14; Birkenhead to Beaverbrook, 28 January 1930, Beaverbrook MSS C41. 
aware of the need to make a new move, but was naturaliy strongly influenced and restrained by the electoral advice he had also received. This had consistently been in favour of some advance, but struck a cautionary note over the electoral consequences of going beyond a tariff on manufactured goods to one on food imports. Even Hannon acknowledged that "the food tax cry is something still of very serious moment to those who represent or who are standing for industrial constituencies". 63 Baldwin framed his speech for the Coliseum meeting in the context of these limitations. Thus salisbury noted after a conversation with Baldwin in the week before the speech:

S. B. is however convinced that any suggestion that we will, or that we might, tax food would be fatal. Nevertheless the press agitation has made a definite fiscal policy necessary. He is inclined to an immediate development of safeguarding - meaning safeguarding thereby steel and perhaps wool.

Baldwin's intentions were the logical product of the political, rather than the economic, situation: the offer to give protection to the major steel and textile industries was the clearest token he could give of his

63. Hannon to Beaverbrook, 7 January 1930, Hannon MSS 1/3; Gretton to Baldwin, 30 January 1930, Baldwin MSS volume 31, f. 23; Ramsden to Baldwin, 24 January 1930, ibid., f. 39; Bayford diary, 7 February 1930; EIA, Exec., 18 February 1930; Salisbury CA Res., NU Exec., 10 December 1929.

64. Memo of conversation with Baldwin, 28 January 1930, Salisbury MSS S(4) 133/67-71. 
desire for advance without straying into the minefield of foodstuffs.

Baldwin's planned initiative at his forthcoming Coliseum speech was also intended in another political context; as the first, rather than the culminating, move towards a renewed phase of appeasement of Beaverbrook by linked concessions and negotiations. The tactios of November 1929 were to be dusted off and re-used once again. Thus offers of mediation in late January 1930 from concerned, respected Conservative figures such as Gwynne and John Buchan, who were extending feelers to both Beaverbrook and Baldwin, were now given encouragement by the latter.65 Appearing to be thawed by these interventions, Baldwin invited Beaverbrook to a preview of his intended Coliseum address. Though at this stage there was no suggestion of negotiated compromise, the channels of communication had been re-opened.66 on 3 February 1930, two days before the Coliseum meeting, Baldwin saw Beaverbrook and "read his speech to him, but did not ask for any comment".67 Though a hopeful indicator, the content of the speech could not in fact venture far enough to directly and immediately appease Beaverbrook and the whole-hogger protectionists. Indeed, given the

65. Buchan to Beaverbrook, 30 January 1930, Beaverbrook MSS C314; Beaverbrook to Elibank, 24 January 1930, ibid., C 126 .

66. Baldwin to Beaverbrook, 29 January 1930, ibid., C19.

67. Lockhart diary, 3 February 1930. 
contradictory tension between the two aims of the Coliseum speech of 5 February - the conciliation of the protectionists, but the avoidance of food taxes at the explicit demand of the pragmatists - it was unlikely to be a complete solution. These tensions came out clearly in the substance of the speech. Once again, Baldwin attempted to reassure critics of his lack of vigour as opposition leader by a strong attack on the government. on the ideal of imperial economic union, Baldwin's rhetoric effectively overlaid the mild reality of his safeguarding policy. The latter amounted almost to the proposal to de-politicise the question by placing the onus for producing a definite plan upon the industrialists of the empire, rather than on the governments. However, two elements in the speech could not be glossed over so easily. Baldwin deliberately postponed the thorny question of agricultural policy for another day, and gave a specific pledge against food taxes in any form. 68

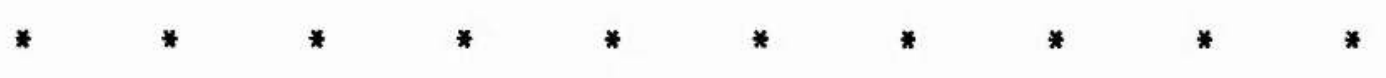

The Coliseum speech was not a solution to the tensions evident within the party in January 1930 but was merely a holding operation, designed to buy time. The policy advance conceded was in the nature of a payment on account only - literally so in the case of the postponed agricultural policy. And it was in this light, as a first

68. The Times, 6 February 1930. 
step forward, that it was judged.69 Certainly the shortterm aim of the speech had been achieved, by defusing the threatened explosion that had been building up within the party. The considerable relief with which the speech was received was not in fact so much an indicator of the real value of its contents, but rather reflected the relief from the considerable pressure now eased, though not removed, by the minimal move forwards. An indicator of its success in this context was the reaction of the Gretton group, who wrote to express their "satisfaction that the pronouncement at the Coliseum yesterday went far to meet the[ir] views".70 The approach adopted by Baldwin in these early months of 1930 was also intended to bring along, by moving in easily assimilated stages, northern Conservative free food sentiment, without losing the toleration of the protectionist lobbies. The Coliseum speech went some way to meeting this aim; whilst on the one hand acceptable to and welcomed by the Empire Industries Association, on the other it offered an escape route to free traders such as the MP for Clitheroe, Sir William Brass.71 Despite the general atmosphere of relieved approval, the reaction from the constituencies remained ambivalent. In southern agricultural areas the 69. Gwynne to Beaverbrook, 5 February 1930, Gwynne MSS 14 .

70. Gretton to Baldwin, 6 February 1930, Baldwin MSS volume 31 , f. 25 .

71. EIA, Parliamentary Council, 6 February 1930; Clitheroe CA, AGM, 15 February 1930; Headlam diary, 5 February 1930. 
Coliseum speech received a qualified weloome; the speech was of use only if it was followed up and expanded into a proper agricultural policy, but on its own it was not enough: "something much more definite, expressed in the simplest possible language, must be given to us".72 on the other hand the reaction from the industrial constituencies of the Midlands and the North was approval containing the implicit assumption that the policy had now been settled, and would progress no further. 73

The Empire Crusade's initial response to the Coliseum speech was welcoming, but the warm and friendly letter of congratulations sent by Beaverbrook to Baldwin immediately after the speech represented not a genuine agreement, but a purely tactical response, decided upon by the Empire Crusade committee. This was designed to encourage Baldwin to continue further the process of conciliation. 74 It was in order to speed up this process of negotiation that Beaverbrook took the apparently contradictory step of restarting his public campaign; in fact, such a move was implicit in his letter to Baldwin of 5 February.75 The

72. Kent Agent's Union, 19 February 1930; Chelmsford CA, Branch Res., 22 February 1930; Eastern Area, AGM, 5 February 1930.

73. York CA, Exec., 10 February 1930, Council, 27 February 1930; Rother Valley CA, Exec., 4 March 1930; Bradford South CA, Exec.., 18 February 1930; Birmingham CA, Management Ctte., 14 February 1930.

74. Elibank diary, 5 February 1930, f. 6 .

75. Beaverbrook to Baldwin, 5 February 1930, Beaverbrook MSS C19. 
aim was compromise via an increase of pressure, and not confrontation. Throughout February 1930 the most significant element in political discourse was the language of negotiation which formed the background to the tactical counters designed to promote a settlement. Beaverbrook, correctly, had been assured that Baldwin's opposition was of pragmatism, not principle, and thus a show of empire free trade popularity in the country could actually assist to bring the two men together by demonstrating that public opinion was, or could be made to be, ready for a fully fledged tariff programme. In short, as Gwynne commented, "S. B. caㅡㅁㅡ be handled".76 Beaverbrook made the running during the first half of February by returning to his public campaign in the agricultural constituencies, pitching his attack to the still unsatisfied farmers. In the absence of an alternative Conservative agricultural policy, "the policy of Empire Free Trade got on like 'wild-fire' in the agricultural districts".77 It was no accident that a large part of the success of Beaverbrook's appeal was that his view that the pledge against food taxes which had been given at the Coliseum was too blunt and final a barrier against any further future evolution of party policy was shared by a substantial element on the backbenches and in

76. Gwynne to Beaverbrook, 2 February 1930, ibid., C149.

77. Elibank diary, January 1930, f. 5; Hilton Young to his wife, 1 Maroh 1930, Kennet MSS $107 / 3$. 
the local Associations. There was no inconsistency between the renewal of the Crusade, and Beaverbrook's desire, often repeated in the private correspondence of this time, to come to an arrangement with Baldwin, whom he continued to believe sympathetic with his aims, and towards whom he was still well disposed. 78

However, the area of divergence between Beaverbrook and Baldwin instead widened enormously into an open breach as a consequence of their next interview, arranged for the morning of 12 February. At this meeting Beaverbrook set out sweeping claims for permeation of the parliamentary party, presumably by the intimidation of MPs and local constituency parties.79 As it is unlikely that Beaverbrook could have expected Baldwin's agreement to such a proposal, the move could only have been intended as another stage in the parallel process of pressure reinforcing negotiations. In a threatening manner Beaverbrook had made clear the potential for disruption that his movement could cause, but this pushed Baldwin towards resistance rather than concession. What was doubly unfortunate, however, was that the last part of the interview produced a serious misunderstanding between the two men. Beaverbrook believed that Baldwin had agreed to his forming a "party", but on this crucial issue the conversation had become confused, and Baldwin maintained 78. Beaverbrook to Amery, 9 February 1930, Beaverbrook MSS C5.

79: Beaverbrook to Gwynne, 19 February 1930, ibid., C5. 
afterwards that Beaverbrook did not discuss a "party", but had used the word "league". 80 This was significant because Baldwin was still thinking of the crusade as a proagandist pressure group, and hoped to confine it to publicity. The difference was more than mere hairsplitting; the misunderstanding complicated the personal relationship of the two men, and also, perhaps even by design on Baldwin's part, encouraged Beaverbrook to go out on a limb and, by starting his own new party in competition with official Conservatism, to run the risk of thereby alienating his supporters amongst the Conservatives of all ranks.

The immediate product of the meeting of 12 February was the launching of Beaverbrook's party. At 3:00 p.m. on that day he called together the Provisional Committee of the crusade, and secured their agreement to its transformation into the new format.81 The public intimation of this was delayed for a few days during which Beaverbrook secured his last essential support - the alliance with Lord Rothermere. The Empire Crusade with its existing membership was thus transformed into a totally different body by a statement released by Beaverbrook to the press on 17 February 1930: "Here and now", it proclaimed, "we will form ourselves into a new

80. Elibank diary, 12 February 1930, ff. 7-8; Gwynne to Baldwin, 21 February 1930, Gwynne MSS 15.

81. Elibank diary, 12 February 1930, f. 7 . 
party - the United Empire Party."82 Despite appearances, this move did not represent the throwing over of negotiation, but was merely intended to produce quicker results. The United Empire Party was not in fact a party in the genuine sense of the word, for, whatever its methods, its purpose remained that of a single-issue pressure group - as Beaverbrook himself freely admitted.83 Forming the party had undeniably assisted Beaverbrook in capturing Rothermere's support, but this was only a secondary by-product and not the primary aim, which remained consistent with Beaverbrook's strategy of progress through agreement. 84 Four days after the United Empire Party was launched, Beaverbrook told Amery that "there is really no difference in my position on account of the formation of the United Empire Party".85

Whilst the establishment of the new party created a new dimension to the political picture, paradoxically the immediate result was an atmosphere in which both sides came increasingly under pressure to find a compromise and close the breach. The formation. of the UEP, as the tightening of existing screws rather than as a radically novel development, certainly increased the pressures upon Baldwin to find some solution. Internal Conservative 82. The Times, 18 February 1930.

83. Beaverbrook to Chivers, 25 February 1930, Beaverbrook MSS B136.

84. Beaverbrook to Grey, 18 February 1930, ibid., B152.

85. Beaverbrook to Amery, 22 February 1930, ibid., C5. 
party opinion demonstrated its desire for an end to the increasingly ominous internecine warfare in an unequivocal fashion: Amery and Horne pressed Baldwin to a further forward move, as did two influential deputations received by the latter on the day the new party was announced, 18 February. The first was a representative group of the Diehard wing led by Gretton, and the second a delegation from the Empire Industries Association; both demured at the rigidity of the Coliseum pledge against further advances in party policy. More significantly, this predictable chorus was reinforced by similar expressions from a much wider spectrum of party feeling.86 The pressure for accommodation was supported by the feeling in a number of the local Associations, and a further brake on progress was removed by Derby's speech at Macolesfield on 15 February, where that political weathercock came out firmly for some further advance.87 In the light of these manifestations of feeling, Baldwin turned down the confrontational tactics urged on him by churchill of putting the issue to the test of a series of by-elections as too dangerous and too divisive, clearly preferring to

86. Leaked to the Daily Mail, 19 February 1930, and presumably accurate as it appear in the autobiographical collection of press cuttings in the Croft MSS; EIA, Exec., 18 February 1930; Clanwilliam to Salisbury, 25 February 1930, Salisbury MSS S(4) $133 / 177$.

87. Cirencester and Tewkesbury CA, Finance and Advisory Ctte., 28 February 1930; Lincoln CA, Special Exec. Meeting, 27 February 1930; The Ii mees, 17 February 1930. 
opt for the path of conciliation. 88 In this he may have been influenced by indications that failure to compromise might imperil the position of the entire leadership. This came in particular with renewed signs of the tendency of the grassroots to take the initiative, in the absence of a lead from above. Paralleling the post-election demands for a greater role for the rank and file and the party conference, the president of the Grantham Association publicly demanded the convening of an emergency conference which would lay down the party's fiscal policy. These pressures from below were disturbing reminders of the state of unrest in the Conservative party during the last period of the Lloyd George coalition government in 1922.

Simultaneously Beaverbrook was also coming under pressure to climb down from the dangerously independent position which he had assumed with the formation oa the new party. For the alarm which that had caused at all levels of the Conservative party produced not only the above-mentioned stimulus to Baldwin to seek a truce, but also found clear expression in a backlash of revulsion against the United Empire Party itself. Beaverbrook was startled at the universally hostile response that his purely tactical move provoked, all the more so for the fact that it contrasted strongly with the cautious general approval in which he had basked hitherto. In transforming his propagandist campaign into a party Beaverbrook came 88. Davidson to Baldwin, 26 February 1930, Davidson MSS. 
into confliot with not only short-term fears based on electoral expediency, but also the instinctive solidarity of the Conservative party. The hostile reaction which resulted was partly one of alarm, compounded by the normal condemnation of factional strife, but the degree of reaction was unmistakeable.$^{89}$ What must have weighed most heavily with Beaverbrook was the fact that this crucial response included even those sectors of the tariff reformers and Diehards to whom he looked for support. When on 12 February Beaverbrook had proposed the creation of a new party to the Crusade Committee, the active Conservatives on it had been "rather staggered at this proposal, as we did not quite see where it was going to lead us, or lead the Conservative Party", and they attempted to act as a brake upon a "determined" Beaverbrook by watering down his manifesto in an unsuccessful attempt to avoid it appearing as an attack on either Baldwin or the Conservative party.90 This inauspicious start was echoed by the rejection of public association with Beaverbrook by even the most apparently dissident Conservative backbenchers such as Ferguson and Gretton. In addition, the mediatory figures and advisors such as Croft, Gwynne and Amery were unanimous in their

89. Erskine to Beaverbrook, 24 February 1930, Beaverbrook MSS B 145; Sutton CA, Exec., 27 February 1930, report in Astor MSS $1416 / 1 / 1 / 122$; Stigant to Salisbury, reporting opinions of Rochester and Chatham CA, 26 February 1930, Salisbury MSS S(4) 133/183-184.

90. Elibank diary, 12 February 1930, f. 8 . 
disapproval of the formation of a distinct party, and the move provoked them to reaffirm their loyalty to the Conservative party without the desired imperial programme in preference to the disruption of the pro-imperial forces.91 Beaverbrook's manifesto produced Baldwin's strongest counterblast yet. This took the form of an interview with the new party journal Home and Empiㅡ를. published on 25 February, which had the effect of a shot across the Crusaders' bow, causing him to pull back; Beaverbrook's aim at this stage was to capture Baldwin, not to drive him into open enmity. 92 Beaverbrook was also having difficulties in keeping his new party firmly on the rails of his policy, as it was tending to become submerged, by Rothermere in particular, into becoming only one point in a full-scale Diehard programme, and he was increasingly worried that his movement had now been captured by an anti-Baldwin cave of Adullamites, which might produce a result he did not desire - the disintegration of the Conservative party. 93

The immediate result of this situation was thus to produce an atmosphere in which both sides desired to find 91. Gwynne to Beaverbrook, 18 February 1930, Gwynne MSS 14 ; Amery to Beaverbrook, 19 February 1930, Beaverbrook MSS C5; The Times, 17 February 1930 .

92. Home and Empire, March 1930.

93. Beaverbrook memorandum, 7 March 1930, Beaverbrook MSS C284; Beaverbrook to Gwynne, 25 February 1930, ibid., C149; Beaverbrook to Londonderry, 9 March 1930, ibid., C224; Beaverbrook to Marjoribanks, 6 March 1930 , ibid.. B167, 
a road back from extreme positions. One symptom of this was the resurgence of influential figures in the role of mediators, to the encouragement of both camps. Several figures, more or less in the confidence of both men, and from the group thought to be both loyal to the party and sympathetic to Beaverbrook's policy, were involved, acting very much in parallel: Horne, Amery, Gwynne, and Elibank. All four of these go-betweens were pulling the same way, in the sense that they all expected some concessions to come from each side in the move to a middle ground. 94 They were also a force for commonsense and stability, attempting with success first to keep lines of communication open during a period of potentially disruptive confrontation, and second to defuse the explosive policy problem. After the misinterpretations of the meeting of 12 February, followed by the announcement of the formation of the UEP on 18 February, it required their intervention before another face-to-face meeting between the two principals could once again become practical politics.

On 19 February Gwyne had an interview with Beaverbrook, and the latter set out on paper his irreducible minimum condition for a deal: that Baldwin must throw off the negative pledge of the coliseum

94. L. S. Amery, My Political Liffe (1955), volume 3, pp. $27-28$. 
speech.95 Gwynne then shuttled backwards and forwards between Baldwin and Beaverbrook during the period 20-24 February, and it was during this process that the crucial policy content of the deal was negotiated, it being agreed that the Conservative leader would no longer "rule out a duty on foreign foodstuffs".96 Baldwin did not find this imprecise declaration difficult to accept, but he was motivated by different considerations, and interpreted his commitment in a contrary spirit to the positivism demanded by Beaverbrook. His pledge to no longer rule out a policy that might at some future date involve a food tax proposal fell far short of any undertaking to actively advocate it. Thus, by 25 February, when Gwynne informed Beaverbrook that "I think there is a chance ultimately of making a bridge", the essential, although artifioial, common ground for a deal had been assured.97 Having sensed Beaverbrook's weakness, Baldwin had no difficulty in firmly resisting an initiative stemming from Elibank four days later to settle on terms far less favourable to himself; by the time Elibank saw Baldwin on 28 February, the wind was blowing from a different quarter. Elibank's main proposal was that the United Empire Party should have the right of nomination to three crucial appointments in the next Conservative government. Baldwin immediately

95. Memorandum given by Beaverbrook to Gwynne at Stornoway House, 19 February 1930 , copy in Beaverbrook MSS C149.

96. Gwynne to Beaverbrook, 25 February 1930, ibid.

97. Loc. cit. 
played the constitutionalist card by refusing to allow any infringement of the Prime Minister's prerogatives. In the event this proposal was not only to prove a tactical blunder in the short term, but it also was to provide Baldwin with ammuntion which he was in the future to use with deadly effect. Ironically, the immediate and practical result of this meeting was not appeasement, but rather an attempt on Baldwin's part to divide the two Press Lords; setting Beaverbrook up in the role of Rothermere's keeper by indicating that he would be prepared to come to an agreement with Beaverbrook alone.98 After these exchanges, there remained only two considerations. The first was that suitable moves of public rhetoric towards conciliation would have to be made in order to prepare the rank and file for a coming together, and remove the atmosphere of hostility. Though accomplished with remarkable speed, this was inevitably a slower process than the private settlement. The second consideration was that, once the two pre-conditions of preliminary negotiation and public rapprocohement were achieved, the two principals would need to meet again face-to-face, to hammer out the detailed mechanics of Baldwin's next pronouncement.

Given the desire in all quarters for a truce, it was not difficult to mould public and party opinion in its favour. This process began, appropriately enough, with a 98. Elibank's memorandum of conversation with Baldwin, 28 February 1930, Elibank MSS SRO GD 32/25/74, ff. 57-9. 
speech by Amery at Edgbaston on 21 February. He drew Empire Free Trade into the accepted canon of tariff reform sentiment, declaring that "it had been, in one sense, the accepted policy of the party for nearly a generation", and, whilst lightly deprecating the formation of a separate party, acknowledged that this move was the product of frustration at the lagging behind of official policy.99 This was reinforced in a speech by Horne on 26 February to the Constitutional $\mathrm{Club}$, in which he set out a 'broad church' definition of Conservative economic policy, on the common acceptance of the fallacy of free trade and the eventual agreed desirability of empire economic unity. His closely argued text thus reduced the matter for debate to limited aspects of means, not yet requiring elucidation: until negotiations with the dominions were opened, it was premature to decide the issue in favour or against the matter of food taxes, and "in the meantime he did not see why Unionists should be divided and herded of in separate pens". 100 Although studiously vague on practicalities, the forthright critique of the existing free trade system represented a genuine attempt to find a

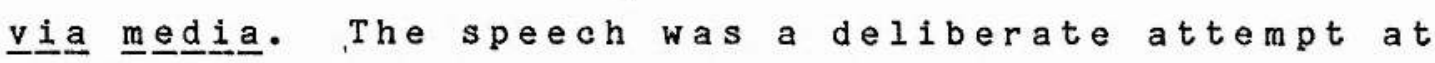
conciliation, for Horne had sounded Beaverbrook in advance, sending him the contents of his speech.101 99. The Times, 22 February 1930.

100. The Times, 27 February 1930.

101. Horne to Beaverbrook, 25 February 1930, Beaverbrook MSS C 178 . 
Elibank acknowledged that:

this speech had a remarkable effect on all the members of the Conservative Party as well as the United Empire Party, as they saw in it a line of accommodation between the two factions.

Beaverbrook now felt able to respond with a public gesture of reconciliation, and used for this a forthcoming speech he was to give at Gloucester on 27 February:

I beg Mr. Baldwin to believe that it is possible now and at once to make a beginning .... I beg Mr. Baldwin to ignore the counsels of expediency .... I should welcome a return of Mr. Baldwin to 10 Downing Street if he goes with free hands .... Let Mr. Baldwin withdraw the pledge at the Coliseum which drove me out. Withdraw it and I will go back.

103

Ironically, Baldwin was far from intending to ignore the counsels of expediency; it was merely that the course of expediency now dictated a compromise, to include just sufficient policy advances to entice Beaverbrook.

The Gloueester speech opened the way to the possibility of another face-to-face meeting between the two leaders. On Sunday, 2 March, Beaverbrook had in fact already. drafted a note to Baldwin, requesting an interview, when a telephone message arrived from the latter, inviting him to attend a 10:15 meeting the following morning. At this morning session on $3 \mathrm{March}$ 102. Elibank diary, 26 February 1930, f. 15.

103. The Times, 28 February 1930. 
Baldwin started the bidding low by offering the traditional double-election strategy to avoid the food tax bogey. This consisted of a promise that Baldwin would pledge himself to calling an imperial conference immediately after the next election victory, and would then ratify its proposals by submitting them to the nation in a second general election. According to the version he gave Elibank, Beaverbrook declined this idea, but indicated "that he would accept a Referendum as a 'secondstring' instead of a second General Election".104 This was consistent with the policy advocated in Horne's speech of 26 February, which had met with much general approval. However, it also appeared to give Baldwin everything he wanted, by postponing into the future the pledge to fight on food taxes, although Beaverbrook was privately convinced that the practical result of such a strategy would be to turn the next general election ípso facto into the referendum. In another sense, it was a victory for Beaverbrook; on the previous occasion that the idea of a $r$ eferendum had been introduced in 1910, it had incurred opposition as a retreat from tariff reform, but the crucial point about Baldwin's adoption of the referendum idea was that it represented yet another stage of advance on his part towards a fullblooded protectionist platform. And it was in this sense that Beaverbrook accepted the idea; not as a final resting place of the party's policy, 104. Elibank diary, 3 March 1930, ff. 20-21. 
but as an umbrella under which he could run his empire free trade campaign within the Conservative party, claiming for it that it did not contradict official policy and would educate the people in favour of that policy. In reality, it was the worst of compromises, for it contained within it the seeds of its own failure; essentially each side believed that it had achieved directly contradictory results by the agreement: Beaverbrook that food taxes were now to be part of the party programme; Baldwin that the referendum had shelved the food tax for the foreseeable future. Certainly before long one, or both, would be disappointed.

The referendum idea now raised was not immediately decided upon, and the question was still in the air when Beaverbrook left Baldwin on the morning of 3 March. Baldwin promised to consider the matter and communicate a decision later that day. The final stage of negotiating the truce occurred after Baldwin summoned Beaverbrook to a second meeting on the evening of 3 March 1930, and intimated his approval of the compromise. Aware that Baldwin was due to address the Council of the National Union at the Hotel Cecil the following morning, and that this would be an ideal opportunity to make public the new position, Beaverbrook hastened to complete the arrangements before then. After leaving Baldwin for the second time that day, he discussed the strategy with Rothermere, Hannon and Horne. Together they drafted a 
letter, which the latter delivered personally to Baldwin on the morning of the $4 \mathrm{th}$, before he left to deliver his speech. The terms outlined in this by no means suggested a cessation of Empire Crusade activities:

we will weloome [your] declaration as a marked advance in the direotion of the policy we advocate. We will continue to organise the United Empire Party ... we will not oppose any member of the Conservative Party who declares for the polioy of Empire Free Trade subject to a referendum on food taxes.

Nevertheless, in the tactical short term Beaverbrook was clearly willing to slacken the pressure and wind up his separate party. To Baldwin this, even if it did not last long, was an advantage sufficiently desirable for him to swiftly overcome his constitutional reservations about the referendum. Baldwin's move did not come anywhere near either solving the question of the party's long-term. fiscal policy, or to securing a permanent elimination of the press campaign, but it did buy him much-needed time with which to consolidate his position.

105. Beaverbrook to Baldwin, relayed via Horne, $3 / 4 \mathrm{March}$ 1930, Baldwin MSS, volume 57, ff, 25-26. 


\section{CHAPTER 3}

\section{The Uneasy Truce: March to June 1930}

Peace broke out with Baldwin's speech to the Central Council of the National Union at the Hotel Cecil on 4 March 1930. The tone of this speech was negative and cautious, postponing yet again the agricultural policy to another occasion, and putting the emphasis on the selective safeguarding of industries as "a more reliable and efficient weapon than general protection". Where the speech went beyond the Coliseum platform was only in the gloss of proclaiming that the previous pronouncement did not preclude "negotiating freely and fully with the Dominions". The key passage, however, was that in which the Referendum was unveiled. Here the posture was entirely defensive. Baldwin portrayed the Referendum as the solution to the danger of having the food tax millstone tied around the party's neck, not only in the next election but also in the case of an election fought on adversarial lines subsequent to any Imperial Conference proposals on Preference. Thus, it took the guise of a solution to the tactical difficulty. Baldwin was unequivocal in following a line designed to appeal to the prejudices and needs of his northern powerbase and likely to secure support amongst the candidates for marginal seats, though his declaration was cold comfort to the farmers in the south: he maintained "There will be no 
food tax at the General Election, and the people of this country will never have to pay a food tax unless they so decide it themselves". 1 But Baldwin was an adroit speechmaker, and quickly passed on from this to the rousing finale of his speech, full of Imperial sentiment and orthodox party cliche, and though in reality signifying nothing, it served to blur the defensiveness of the first part of the speech into a tone acceptable to the forward-looking activists.

The reception of the Hotel Cecil speech was almost uniformly favourable, although significantly whilst all sections agreed on approval of it, behind that agreement still lay fundamental divergences about both the content and the tactical presentation of the party's fiscal programme in the light of the Referendum proposal. Beaverbrook saw it as a weapon with which to advance further, placing the food tax firmly in the forefront of the immediate political struggle, whilst Baldwin and the north saw it as a device which removed the food tax problem altogether from current affairs. Thus, while Baldwin sought to avoid danger by de-politicising imperial issues, and deprecated dividing on party lines over them Beaverbrook and his allies were attempting to do the direct opposite. Under such circumstances, the truce was likely to be shortlived, and to last only so long as the mutual self-deception was not exposed. The essential

1. The Times, 5 March 1930. 
reason for the favourable response of the Conservative party to the Hotel Cecil speech was not as a result of the Referendum policy per se, but because it secured the muchdesired end to hostilities with Beaverbrook's United Empire Party. It was a reflection of its political results, not its slim contribution to the evolution of the clear party programme being so frequently demanded by the backbenchers at this time, that the Hotel Cecil speech was taken up with approval. This process began at the meeting itself, after Baldwin had delivered his speech. Although there was nothing in it on polioy to substantiate such a response, so great was the instinctive pressure to secure unity and show loyalty, that potentially critical resolutions were withdrawn "in the light of the speech made by Mr. Baldwin that morning". ${ }^{2}$ For similar reasons, the Hotel Cecil speech found favour with a wide range of party opinion, including the protectionist and Diehard wings, and the Empire Industries Association Executive carried a resolution of approving congratulation. ${ }^{3}$

But it was the reaction of the constituency Associations to the Hotel Cecil speech which was most revealing, both in the large volume of congratulatory

2. NU Central Council, 4 March 1930.

3. Dawson to Baldwin, 17 March 1930, Baldwin MSS, volume 165, f. 99; Cayzer to Baldwin, 5 Maroh 1930, ibid., volume 31, f. 58; EIA Exec., 11 March 1930; Page Croft to Beaverbrook, 5 March 1930, Beaverbrook MSS C101; Melchett to Beaverbrook, 25 March 1930, ibid., C243. 
resolutions, which were a reflection of the relief at the end of the period of acute tension over the United Empire Party, and also in the rather different emphases contained within that approval from the various regions. This was not so much a question of overt criticism, as of more subtle nuances of phrasing and implication. The greatest measure of relief and approval came, predictably enough, from the urban Midlands and the industrial northern seats; thus in Birmingham, "over 50 branches of our organisation passed resolutions of support for Mr. Baldwin's policy". 4 The attitude that lay behind this was spelled out by Colonel Gadie, the Chairman of the Bradford party, who defined Baldwin's policy as:

Safeguarding [which] would put our Industries on their feet... Col. Gadie replying to the question of taxing food said that Mr. Stanley Baldwin had given a pledge that he would not put a tax on foodstuffs unless the country decided by referendum to accept same

The assumption was that food taxes had been cut out of practical politics. Though expressing similar general approval, this was far from the conclusion drawn by the southern and agricultural regions. Thus the Bath Conservative Association recorded its confidence in

4. Birmingham CA, Central Council, 21 March 1930; Wakefield CA, AGM, 6 March 1930; Stockton CA, AGM, 11 March 1930; Rother Valley CA, Exec., 4 March 1930; SUA, Western Divisional Council, 5 March 1930.

5. Bradford CA, Central Ctte., 26 March 1930; Yorkshire Prov. Area, AGM, 22 March 1930. 
Baldwin as leader and pledged itself "to support his policy of freer trade within the Empire", which of course would of necessity have involved a tariff on food as well as manufactures. ${ }^{6}$ However, temporarily obscuring these differences was the overall relief that the danger of the fratricidal war which had seemed inevitable had been removed. 7

The long-term implications of the Hotel Cecil speech and the tactics that it enshrined were most clearly elucidated by the three principal 'neutral' Conservativeoriented newspapers. ${ }^{8}$ None was happy with the Referendum as a constitutional innovation; the Morning Post spoke for much backbench opinion in editorialising that "little as we like referenda, it is at least a great advance on the policy of negation which has hitherto shackled the Conservative Party", though they were wide of the mark in supposing that this marked the substitution of idealism for pragmatism. But it was Garvin, writing in The Observer, who most accurately categorised the basis of the party's reaction: "The Unionist party exalted, chiefly because it was delivered from the deadly menace of cut-

6. Bath CA Exec, 11 March 1930; Basingstoke CA, Exec and Finance Ctte., 6 March 1930; Warwick and Leamington CA, Exec.. 13 March 1930; West Dorset CA, AGM, 21 March 1930; Norwich CA, Annual Report, 30 May 1930; City of London CA, Exec., 6 March 1930.

7. Oxford City CA, Finance and GP Ctte., 7 March 1930; South Kensington CA, Exec., 12 March 1930.

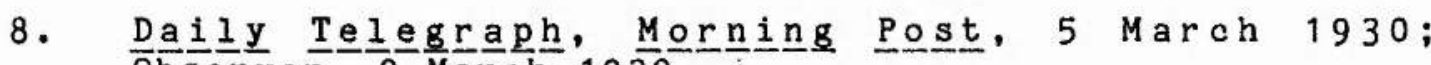
Observer, 9 March 1930 . 
throat candidatures all over the country". Garvin also pointed out that the truce had not by any means solved the divergences of policy and presentation:

The Unionists have saved themselves from rushing to destruction, but salvation is another matter ... other arguments than those used by Mr. Baldwin at the Hotel Cecil last Tuesday are very much required. He must sound a stronger and more ringing note.

These long-term imperatives were obscured by the shortterm relief of the party organisers that the attacks of the Crusaders would cease, and of the cautious pragmatists, like Derby, that not too much had to be conceded to achieve this. 9

This relief referred not only to the ending of divisions within the Conservative Party ranks, but also to the ending of open warfare between it and the Beaverbrookled United Empire Party, for Beaverbrook had also come into line, as agreed, behind the Hotel Cecil speech. In one sense Beaverbrook was the prisoner of his own tactics; having urged the referendum on Baldwin, he had little choice but to react favourably and put his trust in Baldwin, despite the negative tone of the Hotel Cecil address. The logic of his position forced him to advise his followers that "All supporters of Empire Free Trade must welcome Mr. Baldwin's statement and accept the

9. Davidson to Beaverbrook, 5 March 1930, Beaverbrook MSS, C111; Derby to Beaverbrook, 6 March 1930, ibid., C 113 . 
assurance which he has given."10 It also led Beaverbrook into winding up the United Empire Party, and to reconstitute it as "the United Empire Crusade, as now the policy had been achieved, education and all propaganda was necessary throughout the country". 11 To another supporter he explained:

although the position is somewhat changed on account of $\mathrm{Mr}$. Baldwin's speech, we shall continue to carry on the campaign for Empire Free Trade, but in conjunction with the Conservatives.

The winding up of the United Empire Party, however, also provoked a break with Rothermere. Although Beaverbrook was convinced he needed the powerful support of the other press baron's newspapers, 13 he had become increasingly worried by Rothermere's tendency to turn the UEP into a party with a full-scale Diehard programme. Inevitably, with the withdrawal of Beaverbrook, the UEP was captured by Rothermere for his own platform. On 7 March Rothermere produced a five-point Diehard manifesto which he intended to publish the next day, and sent a copy to Beaverbrook. In it he claimed that "it was for the

10. Beaverbrook to Mr. and Mrs. Abbott, 8 March 1930, ibid., B123.

11. Elibank Diary, 6 March 1930, f. 28.

12. Beaverbrook to Clyne, 5 March 1930, Beaverbrook MSS, B137.

13. Beaverbrook to Amery, 7 March 1930, ibid., C5. 
fulfillment of these principles that the members of the United Empire Party enrolled themselves through the Daily Mail and its associated newspapers". ${ }^{14}$ Beaverbrook could not accept the contention that the United Empire Party had ever been anything more than a single-issue pressure group; hence its supercession under the new circumstances. He had little choice but to counter with a press statement of his own, denouncing Rothermere for instituting "a complete departure from the agreed aims for which the United Empire Party was formed". 15 To drive the point home, a further announcement appeared on the same day, to the effect that the United Empire Party fund, having fulfilled its purpose, was to be returned to its donors. Thus the immediate impact of the truce, which had been deliberately negotiated by Baldwin with Beaverbrook to Rothermere's exclusion, had been an open division between the former allies. 16

This split caused Beaverbrook more anxiety than it did Rothermere. Beaverbrook had always rated the power of newspapers highly, and thus he naturally both cherished and feared the influence of the Rothermere press. That Rothermere would continue the fight after the truce was arranged he had not expected, and now he began to feel outflanked by a potentially dangerous and disruptive

14. The Times, 8 March 1930.

15. Ibid.

16. Elibank diary, 7 March 1930, f. 30 . 
rival. As a result of this, Beaverbrook came to question his tactical wisdom in having suggested the referendum and concluded the truce in the first place. In this mood he became increasingly obsessive over signs of caution amongst his Conservative allies. A part of this pattern was Beaverbrook's touchiness over the way the conclusion of the truce had been portrayed as a victory for Baldwin over himself in certain other newspapers. This was only a straw in the wind, but it indicated the fragility of the agreement. Beaverbrook in any case saw the truce as a temporary expedient designed to further his idea, and not as a final consumpation: "My principle is - take a trick when you can and go on with the game. our policy has gained much from recent events", he wrote. ${ }^{17}$ So long as Beaverbrook felt that the referendum and the truce were assisting, not delaying, the progress of Empire Free Trade, he would maintain it as a worthwhile advance. ${ }^{18}$ The crucial point remained the way in which Baldwin would operate the truce: "Everything now depends upon the sincerity of Baldwin's declaration about the Referendum. I trust him completely."19 But Beaverbrook was aware of the dangers of having placed the future of his ideal in the hands of someone else less exclusively committed to it, and he oscillated between natural caution in this 17. Beaverbrook to Edwards, 8 March 1930, Beaverbrook MSS, B144.

18. Beaverbrook to Garvin, 12 March 1930, ibid., C140.

19. Beaverbrook to Croft, 9 March 1930, ibid., C101. 
respect and his desire not to relinquish his weapons totally to Rothermere on the one hand, and a genuine desire to make the truce work if he could on the other. Although from day to day his course as a result appeared erratic and inconsistent, in fact he blew hot and cold in direct relation to the latest manifestations of Conservative Party opinion. Gradually throughout the period from the middle of March to the end of May 1930 Beaverbrook came to the view that his trust in Baldwin had been misplaced, and that he would have to return to the tactics of open warfare.

The genuinely successful phase of the truce in reality lasted only three weeks, from the Hotel cecil speech until the publication of the Salisbury letter on 25 March. But even in this first period, the nature of Beaverbrook's dilemma, whether to work within or without the formal party structure, was apparent from his first public speech after Baldwin's statement at the Hotel Cecil, at Norwich on 8 March:

I welcome with all my heart the powerful support of the Conservatives.... I shall continue to the utmost of my ability and strength to lead the Empire Crusade.... I do not fear the cry of the 'stomachtax'. What I fear is timidity, hesitation, doubt and uncertainty in high places.

20. The Times, 10 March 1930. 
From 25 March onwards, events increasingly confirmed Beaverbrook's belief that the main obstacle to his success lay firstiy in the influence of Free Traders such as Salisbury and Churchill, and pessimists such as Davidson, and finally in Baldwin himself. The progress of the truce towards dissolution, although erratic and obscured by initiatives of partnership and consultation from both sides, is clearly apparent from the middle of March.

The first phase, spanning the period from 4 to 25 March, can be categorised as the attempt at genuine cooperation. Davidson made several efforts to draw Beaverbrook into a closer formal relationship as the codirector of the forthcoming propaganda campaign, involving him in the hope of both appeasing his restlessness, and sharing the responsibility as a protection against criticism. 21 Personal interviews continued to be the favoured method of the party leadership in conciliating Beaverbrook's restlessness: Baldwin saw him on two occasions in this period, as also did Davidson, and Neville Chamberlain, who had recently returned from a long tour of East Africa. The clearest symbol of this genuine drive for fusion on the part of the leaders was the invitation for Beaverbrook to attend and sit on either the newly established Committee of Business, an informal Shadow Cabinet, or on a Committee to direct the Imperial and fiscal campaign of the Party. These invitations also 21. Davidson to Beaverbrook, 7 March 1930, Beaverbrook MSS, C 111 . 
symbolised the problems of the truce period: they were extended to Beaverbrook in a confused and equivocal fashion, rather than openly and formally, and they were declined by the latter, who continued to waver between support and antagonism.

This restlessness was only too apparent even in these early hopeful contacts. Davidson noted in a memorandum of his session with Beaverbrook on 12 March: "I asked him what he proposed to do in the future, and he said that he did not know, but ... In the meantime he would sit tight". 22 The confusion of his position came over in the second interview, held two days later. Davidson wrote that Beaverbrook

proposes to continue the Crusade, spending a great deal of money .... He proposes to raise a fund in small subscriptions for his Crusade .... He accepts absolutely Baldwin's Cecil speech, but he is going to work amongst the public to convert them to food taxes.

The conclusion Davidson drew was a comforting one, provided only that there did not appear to be any backsliding on the part of the party leaders: "there is no doubt that, provided we stand pat on the cecil policy, we shall get his full support". 23 .

22. Memo of conversation with Beaverbrook, 12 March 1930 , Davidson MSS.

23. Memo of conversation with Beaverbrook, 14 March 1930 , ibid. 
Beaverbrook, however, had little faith or confidence in Davidson, and if anything their conversations increased his dissatisfaction and reinforced his doubts on the referendum. 24 Baldwin deliberately attempted to further appease Beaverbrook, with a speech delivered to the Junior Constitutional Club on 12 March. ${ }^{25}$ But whilst this was a useful exeroise in flattery, it contained no signs of the further advances after which Beaverbrook was beginning to hanker. He had already indicated the options of future activity open to him in conversation with Davidson:

He said he had three alternatives: (1) To revive the Crusade with increased intensity .... This would require at times criticism of the Conservative Party. He could only re-start the Crusade, say, a month hence, by criticising the apathy and the lethargy of the Conservative Party, and probably while accepting the Referendum, explaining quite definitely that food taxes were the only thing to save British agriculture. (2) To turn over the Crusade to the Tory Party and let us runit, and (3) to say' I have finished my work. The Conservative Party has come into line: the raison d'etre of the crusade has gone.'

\section{6}

It was in these circumstances that the public hesitancy of the unguarded pronouncements by a number of leading Conservatives of free-trade inclinations took on a significance beyond their real import. In point of fact, as the fate of their initiative demonstrated, the free 24. N. Chamberlain Diary, 12 March 1930, NC 2/22.

25. Elibank Diary, 10-12 Maroh 1930, ff. 35-37.

26. Memo of conversation with Beaverbrook, 12 March 1930, Davidson MSS. 
traders had now lost all power even to put a brake on the Party's progress towards protectionism, never mind actually to recover lost ground. But Beaverbrook did not understand the relatively loose rein Baldwin allowed, or had to allow, his colleagues when in opposition, and his reluctance to proscribe deviance in either direction, from Amery to the free traders, unless it should be unavoidable. To some extent, this loose control was also a tactical decision on Baldwin's part; it was thought that "he does not exeroise party discipline because he intends to remain as vague and elusive as possible".27 Five incidents in late March and early April served to feed the flames of Beaverbrook's paranoia about Conservative defeatism, and his restlessness at being a politician who had lost a party, but not yet found a role. The first three incidents may be grouped together, as they consisted of similar expressions of doubt or negativism on the part of three prominent Conservatives: two ex-Cabinet Ministers, Churchill and Lord Eustace Percy, and a rising former junior minister, W. Ormsby-Gore. Of these, Churchill's speech to his constituents at Wanstead on 18 March was typical, making it quite clear:

There would be no protective taxes on food unless the nation upon a direct vote on this definite issue decided that it was in the general interest. Any Conservative candidate was entitled to say to his

27. Outhwaite to Beaverbrook, 3 April 1930, Beaverbrook MSS, C284. 
constituents, 'No food taxes unless you vote for them yourselves'.

The tone of this was bad enough in Beaverbrook's eyes, but what was worse was the implication that neither Churchill nor the rest of the Party was going to make any real attempt to persuade the electorate to choose in favour of food taxes now or in the future. The fourth incident seemed symptomatic of this de facto dropping of the issue; the cautious platform of T. O'Connor, the Conservative candidate preparing for the imminently anticipated Nottingham Central by-election.

The most serious incident of them all, however, was the publication in The Times on $25 \mathrm{March}$ of a letter from the leader of the Conservative Party in the House of Lords, Lord Salisbury. In Elibank's words, it

upset the whole applecart. The effect of this letter is that whilst praising Beaverbrook and Baldwin for the policy ... he regards it as quite impracticable at the present moment.... In other words, he has thrown over the policy of Baldwin and whilst asserting that he is no Cobden Free Trader, he preaches the Cobden faith in this letter.

The reception that met Salisbury's initiative, and the defeat he suffered, served to expose the weakness of the

28. The Times, 19 March 1930.

29. Elibank diary, f. 43. 
Free Traders even when occupying powerful positions in the hierarchy. Beaverbrook himself was outraged, asserting that "there must necessarily be a crisis resulting from the Salisbury letter", 30 but the real source of his strength was the similar reaction which it provoked in the ranks of the Conservative Party. Because Salisbury and the Free Trade group now seemed to be the ones endangering the fragile and precious atmosphere of unity, they received absolutely no support from those quarters in which they might have expected to strike a chord. Yet they had provoked the wrath of the protectionist right, who could for once portray themselves in the role of defenders of the official party line against divisive groups. Elibank noted that the letter "has created great antagonism in the minds of many of the old Unionist Party". 31 Considerable pressure was placed on Baldwin to denounce the letter, and on Salisbury to withdraw it. A formal letter from Gretton, signed by twenty-five Diehard MPs, was one aspect of this; even more serious was the threat from Page Croft to use the EIA as a forum for a meeting of the Parliamentary Party, one hundred and eighty-seven of whom were members of it, as a potential kangaroo court. The EIA executive decided on 2 April to inform the Chief Whip that such a meeting would be called the following week "unless strong action was taken to

30. Beaverbrook to Lady Elibank, 25 March 1930, Beaverbrook MSS, C126.

31. Elibank diary, f. 43. 
repudiate Lord Salisbury's letter", and Page Croft communicated this threateningly mutinous resolve to Salisbury directly. 32 Under this barrage, Salisbury and the other free traders were forced to retreat. Partiy in order to save Baldwin from the necessity of pronouncing on the issue, Salisbury wrote a second letter to The $\underline{\text { Times }}$ which appeared on 8 April, ostensibly as a clarification, in fact "practically renouncing" the previous letter: Beaverbrook "considered that Salisbury had come right down and that it was a regular 'crawl'."33 In the face of this, and under similar pressure, crucially both from within the party as well as from the threat of independent crusade challengers in their seats, the other Free Traders also compromised, announcing a facesaving adherence to the Hotel Cecil line.34 But these events had considerable impact on Beaverbrook, and their corollary was his declaration to a meeting of Empire Crusaders at the Savoy Hotel that

the Crusade must go on with renewed energy and redoubled vigour ... they retained their independence and their liberty of action .... They were opposed to those who shirked the issue....

32. Gretton et. al. to Baldwin, 3 April 1930, Baldwin MSS, volume 31, ff. 70-71; EIA Exec., 2 April 1930; Croft to Salisbury, 3 April 1930, Salisbury MSS S(4) $134 / 122-3$.

33. Elibank Diary, f. 49.

34. O'Connor, speech at Nottingham, The Times, 22 March 1930.

35. The Times, 26 March 1930; Davidson to N. Chamberlain, 26 March 1930, Davidson MSS. 
This was the first stage in Beaverbrook's progress towards choosing the first of the three alternatives which he had outlined on 12 March to Davidson; to revive the Crusade as an independent force. The strains which these events had caued in late March and early April did not produce an immediate breakdown of the truce. They placed it in a more precarious position, as a result of confirming Beaverbrook's touchiness and Baldwin's apparent lack of decisive control, and by provoking a semi-revival of the Crusade.36 Beaverbrook noted the comments of Neville Chamberlain, who "attributed the present situation to a feeling of distrust in every quarter", and added for himself that "I am growing more and more pessimistic at the prospect of making any progress on present lines". 37

However, breakdown was avoided for four reasons. First, the obvious rout of the Free Trade counterattack had removed some of the tension. Second, the efforts of several leading figures on both sides to hold the precarious truce together had some effect in reconciling Beaverbrook. These attempts, together with the third cause, the superficial co-operation of both camps in fighting the West Fulham by-election, which took place between 12 April and polling on 7 May, preserved at least the appearance of unity throughout the month of April. But the fourth reason was the most important of all: the 36. Beaverbrook to Winterton, 5 April 1930, Beaverbrook MSS, C 328 .

37. Beaverbrook to Rothermere, 22 March 1930, ibid., C284. 
fact that Beaverbrook continued to trust Baldwin's sincerity. Should that prop fall, then the others would not prove strong enough to support the truce. Hence the importance of Beaverbrook's belief that "Baldwin, however, is faithfully adhering to the policy he laid down in his speech of March $4 t h$, but there are many rebels in his own camp." 38

The pattern of the mid-phase of the truce, from Baldwin's speech at Manchester on 7 April to his next public pronouncement at Sheffield on $8 \mathrm{May}$, was of the slow erosion of this confidence in Baldwin, despite the efforts of mediating figures and co-operation in the west Fulham by-election. The conciliators represented a strand of party opinion which wanted Beaverbrook's policy, or a fair approximation to it, to be adopted, whilst at the same time they feared the possible consequences for both that policy and the Conservative Party of all-out warfare between the factions. In the sense of the greater or lesser degrees to which they were prepared to support an extra-party pressure force to achieve their political aims, these figures were placed along a spectrum of opinion ranging from the Crusade Executive to that part of the Conservative Party which sought an advanced Imperial Policy. Thus Elibank from without, and Horne, Croft, Amery and Neville Chamberlain from within the Parliamentary party, all sought for the same reasons to 38. Beaverbrook to Elliott, 9 April 1930, ibid., C129. 
make the truce work. Their initiatives certainly gave it some stability, and probably made it last longer than it otherwise might have done, but the power of decisions lay between the principals on either side and beyond the reach of these albeit powerful figures.

Neville Chamberlain deliberately set out to keep the truce intact as the best means of progress. 39 Until the end of April, Chamberlain remained optimistic about the possibility of a genuine working relationship. $40 \mathrm{He}$ was not alone in offering Beaverbrook an unofficial alliance in this period, with the intention half of pulling his teeth, and half of using him to frighten the party on: Amery and Page Croft also adopted similar tactics. Croft attempted to channel Beaverbrook's energies into more constructive and controlled use by inviting him on 12 March to take a leading part in the Empire Industries Association. 41 A fortnight later he encouraged Beaverbrook deliberately to open a campaign in Cornwall. The point of this was that the Conservatives had lost every seat in Cornwall to the Liberals in the 1929 election, and. whilst such a campaign would reap great benefits for the party, Croft pointed out, "you will be raising enthusiasm without coming into any definite clash

39. N. Chamberlain to Beaverbrook, 7 April 1930, ibid., C 80 .

40. Ibid., 15 April 1930.

41. Croft to Beaverbrook, 12 March 1930, ibid., C101. 
with sitting Conservative Members. 42 In this period Croft and Amery moved closer to an open identification with Beaverbrook's campaign, a process which the flexibility of the truce period made compatible with party loyalty. ${ }^{4} 3$ The clearest examples of the nature of these mediating influences, however, were the unsuccessful initiatives of Elibank, which culminated in his arrangement for a meeting over dinner on 3 April, held in a private dining room at the Savoy Hotel, to which he invited Beaverbrook, Horne, Neville Chamberlain, Hailsham, Cunliffe-Lister and Amery. Elibank recounted:

I tried to throw oil on troubled waters by suggesting that all those present were the stalwarts of the party, and their only anxiety was to see that the polioy was carried out and that he, Max, should trust them to see that this was done.

The dinner was a failure: if anything by creating a misunderstanding between Chamberlain and Beaverbrook, it made matters worse rather than better. 44

From this points onwards the situation continued to drift without improvement. By the middle of May, experience was demonstrating the lack of room for manoeuvre open to the loyal moderate protectionists, who were being ground between the upper and nether millstones of complete revolt against BaIdwin, or the 42. Ibid., 24 March 1930.

43. Beaverbrook to Croft, 16 April 1930, ibid., C101; Amery to Beaverbrook, $5 \mathrm{March}, 13$ and $17 \mathrm{April}$, and 6 May 1930, ibid., C5.

44. Elibank Diary, ff. 44-5. 
opposite position or being forced into supporting him on constitutional grounds against the pretensions of the press lords. 45 The cracks apparent in this middle phase of the truce, during the month of April, were papered over by the surface co-',peration of both sides in the West Fulham by-election. The contest took place between the vacancy of the seat, on 12 April, and polling on $7 \mathrm{May}$. The by-election campaign seemed to exemplify the truce at work, with the comblnation of the Crusade, Beaverbrook's influential London press, and Central office, behind a mutually acceptabla local candidate. Sir Cyril Cobb's political attitudes were such that Beaverbrook, even had he wished, could harlly have done otherwise than throw all his weight behind the offical nominee. Cobb was an influential figure in the Navy League, and agreed with much of Rothermere's Diehard position. Above all, Cobb was a sincere supporter of Imperial Preference and Empire Free Trade, and known to Beaverbrook as such. 46 Beaverbrook determined to try and secure as substantial a victory for Cobb as possible, to prove the electoral value of his policy. "If we win this contest, the conservative Party will be stampeded", he wrote. 47 In fact, the

45. Comments of Horlle noted in ibid., f. 53 .

46. Beaverbrook to Rothermere, 24 April 1930, Beaverbrook MSS, C284.

47. Ibid., 27 April 1930. 
Crusade role in the by-election was kept to a minimumby the firm gripkept on the contest by central office, which controlled the direction and organisation of the fight through its London area agent, Edwards. Beaverbrook made the best of this, not wishing to rock the boat, and claimed that Edwards was in any case the most efficient man available. The calculated result was that, as Beaverbrook himself described, the Crusade effort was limited to only those parts of its appeal that the Conservative party wished to exploit - Beaverbrook's London daily press, and Beaverbrook's own charisma as a platform orator. 48 Beaverbrook immersed himself completely in the by-election for three weeks, giving the party leadership a much-needed breathing space. He had been adroitly outmanoeuvred; any failure could be placed at the doorstep of his policy, while any success claimed credibly as the contribution of the official party machine.

The result, on 8 May, was a very narrow victory indeed; Cobb gained the seat by a margin of only 240 votes. This result was interpreted quite differently by Beaverbrook and by the party leadership. During the course of his campaigning, Beaverbrook became aware how much the social character of Fulham was changing, into an area with a preponderance of Socialist voters. Under such circumstances, he wrote to Gwynne, even a narrow victory

48. Beaverbrook to Elibank, 4 May 1930, ibid., C126. 
appeared to be a considerable achievement. 49 Whilst Beaverbrook took the by-election to be an encouraging signal, the party leadership, expecting a much bigger margin of victory, looked on a gain by only 240 votes as tantamount to defeat, and a negative sign of the dangers of a full-blown Crusade policy.50 This dichotomy of interpretations, which was to be a feature of the ambiguous results of most of the by-election fights of the period, was to prove an important contributory factor in widening the gulf between the crusaders and the Baldwinites, encouraging each to progress a stage further down the road they were already travelling. Nonetheless, West Fulham seemed to demonstrate the success of the truce, with Baldwin sending after the declaration of the result perhaps the friendliest communication he was ever to pen to Beaverbrook, beginning "My dear Max", and offering congratulations "on your gallant conduct in the arena". 51

The excitement of the West Fulham contest held the alliance together during April 1930, and obscured the growing and real divergence between the two sides. However, Baldwin's political strategy was partly unveiled in his only plaftform speech scheduled in April, at Manchester on the $7 \mathrm{th}$. In this address, Baldwin dwelt at 49. Beaverbrook to Gwynne, 9 May 1930, Gwynne MSS, 14. 50. Davidson to Gwynne, 7 May 1930, ibid., 18.

51. Baldwin to Beaverbrook, 7 May 1930, Beaverbrook MSS, C 19 . 
length on the value of safeguarding as the principal remedy available. Inter-imperial trade was mentioned in the context of its future possibilities, and the function of the referendum in postponing the food tax issue was made quite clear. 52 However, the negativism of this portion of the speech was balanced by a vague, but inspirational, final section that sounded the trumpet for "those two great lines of the policy that we shall work [for] - safeguarding for our own people and Imperial Unity for our people and for the Empire." Beaverbrook's faith in Baldwin survived this diminished but not destroyed, though it was evident that if Baldwin were to continue speaking in this vein Beaverbrook would claim it was a breach of the agreement. In the meantime, coming as it did hard on the heels of the Free Traders' attack, but before their rout, Beaverbrook ascribed the lack of fire in the speech to weakness under the influence of the caution of Davidson, Salisbury and Churchill rather than being a true reflection of Baldwin's own mind. Thus Beaverbrook for a crucial period turned his fire against these elements, when in fact their influence was small and diminishing daily. 53 So long as Beaverbrook concentrated upon the symptoms, rather than the cause, of the failure of the Conservative Party to fall in line behind the Empire Free Trade Policy, his course was bound to be

52. The Times, 8 April 1930.

53. N. to Ida Chamberlain, 20 April 1930, NC 18/1/692. 
erratic. Thus at Hertford, addressing the local Conservative Association in Salisbury's own backyard on 8 April, he said that "he had been driven to the task of addressing meetings up and down the country. Their policy was languishing for want of exponents".54 Yet three days later at Nottingham, he proclaimed his faith in Baldwin and pinned the blame, not only for present dissent but also for having thrown a spanner into the protectionist works between 1924 and 1929, on the Conservative Free Traders. He affirmed that he

understood Mr. Baldwin to promise, if returned to power, Empire Free Trade, with a tax on foreign foodstuffs. He threw out safeguards for himself in the form of a Referendum. They agreed, but they understood him to mean that he would plough a stralght furrow through the Generall Election through a Referendum - and that he would not look back until he had given them their keysitone - a tax on foreign foodstuffs.

It was difficult to square this with the Manchester speech; it was to prove impossible to reconcile it with Baldwin's next public foray, at sheffield a month later.

Between these two pronouncements of official Conservative policy on 7 April and 8 May, the foundations of trust upon which the truce existed were significantly 54. The Times, 9 April 1930.

55. The Times, 12 April 1930. 
eroded by a number of specific incidents and the crystallisation of two more general background themes. It was Baldwin's good fortune that only one of the specific incidents identified him directly with a negative approach. This was the problem of the troubled candidacy of O'Connor in the Nottingham Central by-election, which inevitably involved Baldwin, as such matters as the granting or withholding of official approval to a candidate were prerogatives of the Party Leader alone. o'Connor's attempts to square the circle of satisfying both the demands of Beaverbrook in London and the desires of his by-election audiences in Nottingham Central caused periodic strains. Originally o'connor had veered considerably from the official party line, but the threats of Beaverbrook brought him back from that exposed position to one of sheltering behind the shield of the Hotel cecil policy, interpreted in its most defensive sense. 56 However, the damage had been done, and Beaverbrook, suspiciously receiving the reports of O'Connor's speeches, began to claim that o'connor had forfeited the right to the party label, to the approval of the leader, and to the support of Central office.57 Baldwin, however, could not allow Beaverbrook to become the arbiter of political

56. O'Connor to Baldwin, 3 April 1930, Baldwin MSS, volume 165 , f. 243.

57. Beaverbrook to N. Chamberlain, 8 April 1930, Beaverbrook MSS, C 80 ; Beaverbrook to Davidson, 7 April 1930, ibid., C111. 
acceptability, for the powers of withdrawal of central Office support, and the last resort of official excommunication, rested in part with the local Executive, but otherwise with the Leader of the party alone. Now that o'Connor had shaped up to at least an appearance of orthodoxy, Baldwin determined to block Beaverbrook's pretensions by resisting attacks upon him. This he did partly through the medium of Davidson, his party Chairman, and partiy by sending o'connor a public letter of support.58 In the tactical short term this, together with the efforts of Amery and Neville Chamberlain to dissuade Beaverbrook from his threat of nominating an independent candidate, which would have ended the truce, saved o'Connor's bacon. Beaverbrook acknowledged this by coming to a private bargain with O'Connor, receiving from him promises concerning his future conduct in an interview on 8 May.59 But this was achieved at the price of identifying Baldwin himself more clearly as the main impediment to progress. This was not a conclusion Beaverbrook wished to draw, with its implication of a return to internecine warfare, but it was becoming unavoidable. 60

58. Davidson to Beaverbrook, 8 April 1930, ibid.; Baldwin to O'Connor, 3 April 1930, Baldwin MSS, volume 165, f. 244 (published that day).

59. Beaverbrook to Amery, 8 May 1930, Beaverbrook MSS, C5.

60. Beaverbrook to Davidson, 7 April 1930, ibid., C111. 
The other incidents which directly contributed to the collapse of the truce were all linked to the beleaguered position of the party Chairman, Davidson. His situation was already precarious, partiy as a result of his management of the party before and during the 1929 election campaign, but more seriously for two other causes. The first of these was the resultiof the fact that the party Chairman was also the Chairman of the main organ of rank and file representative feeling, the Executive Committee of the National Union, and was thus institutionally in a position to strangle dissent at birth, and to exploit his powers for the purposes of his appointer, the Leader of the party. Davidson, who was intensely loyal to Baldwin personally, was blatant in his failure adequately to represent the feelingsiof the party rank and file, and muoh of the clamour for intra-party democracy was the product of this. sф great had resentment become, that the whole position of the National Union Executive Chairmanship had been cast into the melting pot, with the result that it was resolved at the 1929 party conference to end the ex=officio position of the party Chairman forthwith, and Davidson's successor as Chairman in mid-1930 no longer had the same powers.61 This much-resented facet of Davidson's chairmanship of the

61. For debate on this issue, see NU Exec., $16 \mathrm{July}, 22$ october, 10 December 1929, 8 April 1930; and at the Party Conference of November 1929; for local feeling: Guildford CA, Exec. 2 May 1930; article in Weekenend Review, 17 May 1930. 
party organisation was exacerbated by the second cause of his unpopularity: his unfortunate personal manner, at once tactless, prickly, and offensive. The examples of the important figures in the party hierarchy outside the. charmed circle of Baldwinites whom Davidson alienated by his methods of business and his manner were so numerous as to provide by themselves a powerful coalition of unrest. 62 He had also made many enemies among the right-of-centre backbench MPs, such as J. Remer, who wrote: "the Conservative Party will never be a band of brothers so long as Mr. Davidson is Chairman of the Party".63 More importantly, Davidson's shortcomings were beginning to be recognised as a liability amongst several powerful figures in the party leadership. Derby wrote bluntly that "we must get rid of Davidson - he is useless", and Neville Chamberlain, thinking along similar lines and also convinced of the need to cut away the deadwood at the Central office, was preparing to move to oust Davidson and replace him with a nominee of his own. 64

62. Correspondence quoted in James, op. cit., pp. 312313; Halsbury-Davidson correspondence, March 1930, Davidson MSS.

63. Remer to Baldwin, 7 April 1930, copy in Beaverbrook MSS, B172; Courthope to Beaverbrook, 17 May 1930, ibid., B139; Hall-Caine to Beaverbrook, March 19 1930, ibid., B135; Elibank Diary, f. 28; Davidson to Hamilton, 6 February 1930, in James, op. cit., p. 312 . 
The desire to jetison Davidson, which was in any case becoming acute by the end of April 1930, was confirmed by two failures of political management on his part. The first of these was the disastrous "Home and Empire" public campaign promoted by Davidson for the month of May. The stimulus for such a campaign had come originally in suggestions from some northern constituencies, and it was only in these urban seats of Lancashire and the West Midlands, and in parts of Scotland, that the campaign aroused any enthusiasm at all.65 one reason for the failure of the "Home and Empire" campaign outside certain limited areas was the fact that May was not considered a good month for political propaganda work, and the launching of an effort then was transparently a tactic of desperation on Davidson's part. Another reason for nonparticipation was the distrust felt by many local executives at this time for any leadership from Central office. However, the main reason for the failure of the idea to catch on outside selected cautious regions was the negativism of the pledge on policy, the securing of signatures for which was the centrepiece of the campaign. Despite repeated interventions by Neville Chamberlain in the drafting stage, the declaration of party policy

64. Elibank Diary, f. 47; Derby to Beaverbrook, 6 March 1930, Beaverbrook MSS, C113; N. to Hilda Chamberlain, $29 \mathrm{March} \mathrm{1930,}$ NC $18 / 1 / 687$.

65. Resolution from Lancashire and Cheshire Prov. Div., NU Exec., 11 February 1930; Accrington CA, Exec., 21 January 1930 . 
contained in the pledge reeked of pragmatic negativism. 66 This cautious interpretation of party policy went down well in seats with a large industrial working class population, or where Free Trade sentiment was still strong.67 Furthermore, in the proces of falling over backwards to satisfy the prejudices of the north, the south had become alienated from the campaign, indicating once again the socio-geographic problems of the ttwo nations' north-south divide which plagued Conservative party politics throughout the era of the tariff reform struggle. The refusal of the south to take up the "Home and Empire" campaign was clearly and unequivocally linked with grievances concerning the retrograde nature of party policy, the lack of an agricultural pledge, and hostility

66. Home and Empire, volume 1, number 3, May 1930; Central office Circular announcing campaign, copy in Beaverbrook MSS, C 111 ; N. to Hilda Chamberlain, 19 March 1930, to Ida Chamberlain, 4 April 1930, NC $18 / 1 / 687,689$.

67. Birmingham CA, Agents Report to Council, 5 June 1930; Walsall CA, Exec., 30 May 1930; Accringtion CA, Exec., 5 April 1930; North Cornwall CA, Exec., 14 April 1930; Lincoln CA, Exec., 24 April 1930; on north-east Scotland, Ford to Baldwin, 26 June 1930, Baldwin MSS, volume 57, ff. 45-57. Even in the north, some associations were doubtful about the Pledge: Clitheroe CA, Council, 24 April 1930. 
to Central office. 68 It is clear that the vocal hostility of a substantial number of Associations was only the tip of the iceberg; many others voted with their feet by ignoring the campaign altogether. An analysis of the surviving Association records suggests that at the most generous estimate only one quarter of local parties seriously participated. On any criteria such a response is in itself a dismal. failure and evidence of mismanagement by, and loss of confidence in, the party organisers. The party's Principal Agent, Robert Topping, acknowledged this fact: "Our Home and Empire Campaign is not going at all well... the constituencies are disinclined to follow our lead."69

If the debacle of the "Home and Empire" campaign damaged further Davidson's uneasy position, the second incident finally sealed his fate. This concerned the publication by central office on his inștructions of publicity leaflet in which the depiction of party policy

68. Ashford CA, Joint Standing Ctte., 3 May 1930; South Oxfordshire CA, Exec., 7 May 1930; East Dorset CA, Exec., 7 April 1930; North West Wiltshire CA, Exec., 1 May 1930; Uxbridge CA, Exec. and Council, 26 April 1930 ; Chelmsford CA, Exec.. 13 June 1930; Ealing CA, Exec., 11 April 1930; St. George's CA, Exec., 12 and 21 May 1930; Blackpool CA, Exec., 28 April 1930. The minutes of many other associations are silent on the subject of the campaign, which must suggest strongly that they did not participate; if they had, either a note of the result, or traces of the financial and administrative arrangements, would have appeared in their minutes.

69. Memo, Topping to Davidson, 2 May 1930, in James, op. cit., pp. 335-336. 
seemed to be a further retreat from the Hotel cecil position. This document, known by its reference number of leaflet 3153 , contained a yet firmer 'no food tax' promise, and watered the policy down further from Empire Free Trade to being only some exercise in limited imperial bartering more akin to the activities of the Empire Marketing Board than to the grand conception of Joseph chamberlain.70 once again, the breakdown in mutual understanding and confidence was revealed. Davidson sent Beaverbrook a copy of this document in its printed form the day before its release, for information as a courtesy; this hardly accorded with Beaverbrook's belief that he would see such items at the drafting stage so that his role would be that of a participant, not merely a spectator. During the three weeks following the release of leaflet 3153 the chorus of disapproval grew stronger. Not surprisingly, several of the more advanced southern constituency associations reacted strongly to the leaflet; calling it "innaccurate and misleading" and demanding that "it should be withdrawn from publication". 71

Beaverbrook's reaction paralleled this, becoming progressively stronger with the passage of time. Writing

70. Leaflet 3153 , in James, op. cit., p. 332.

71. Chichester CA, Finance and GP Ctte., 28 April 1930; Brighton CA, Res. of 17 April 1930, copy in Beaverbrook MSS, C 111 ; Chairman of Dartford CA to Beaverbrook, 26 April 1930, ibid., B165. 
to Amery he described his sense of trust betrayed: "As to leaflet 3153 , it is a starting case of bad faith..."72. Beaverbrook indicated his unhappiness at the course of events by publicly attacking the offending publication in a press statement released on 16 April, ominously declaring that "the publication of this leaflet is one in a chain of events which have gradually made the present position extremely difficult". 73 However, Beaverbrook had not yet come to the point of a definite breach, for he still desired to work with Baldwin, not against him, and he still hoped Baldwin would move towards his position. 74 Instead, Baldwin chose to take the opposite path, and from this point onwards the truce deteriorated, until his speeches of early May finally shattered it.

Two longer term factors were also pulling the props out from underneath the truce. In one direction the trend of party opinion continued along its evolutionary path towards open protectionism, and thus to a rejection of the referendum policy in favour of the call for the immediate "free hand" to impose tariffs as soon as the party next gained power. By the beginning of June politicians were

72. Beaverbrook to Amery, 14, 20 and 25 April, 1930, Beaverbrook MSS, C5.

73. The Times, 16 April 1930.

74. Beaverbrook to Hall, 25 April 1930, Beaverbrook MSS, B153. 
beginning to sense that a further shift in public opinion generally had taken place, as a result of rising unemployment, undermining free trade opinion and causing a move towards tariffs: "we are not far from a landslide on Protection", noted Austen Chamberlain.75 Even Davidson thought that in the industrial north, "there is a growing swing towards Empire and Safeguarding".76 But public opinion did not advance either quickly or uniformly, and thus the foundation of any definite policy upon the consideration of public acceptability was as likely to succeed as building a house on shifting sandbanks. Furthermore, as was so often the case, if public opinion had advanced once step, the opinions of the party rank and file, having sensed this, rather than narrowing the gap, themselves were stimulated into another leap forward. 77 Thus Baldwin's dilemma of reconciling electoral pragmatism with the demands of his followers became if anything, for a short while at least, even more difficult. For it was quite clear that, even within the dichotomy of the northsouth contradiction, the general trend of grassroots opinion was consistently moving away from the referendum towards the free hand. The divergence between north and south was one of pace: though the evolution of fiscal opinion in the North was not static, it did not relinquish

75. A. to Hilda Chamberlain, 14 June 1930, AC 5/1/505.

76. Davidson to Beaverbrook, 11 April 1930, Beaverbrook MSS, C 111.

77. Croft to Beaverbrook, 6 June 1930, ibid., C101. 
the shelter of the referendum as promptly as did the South. In part this was the consequence of the different degree of pressure exerted by the Empire Crusaders still in existence in local branches, and in the process of being reactivated as a pressure group. Essentially their impact was only upon the southern seats; in areas of traditional agricultural Toryism, in the suburbs, and in the seaside resort towns.78 However, in the North the Crusade was weak to the point of non-existence, and thus the natural division between the 'two nations' was exacerbated by unequal distributions of the pressurising effects of the Crusade. The widening gulf that resulted was clearly visible, and can be seen in the contrast between the views of the prospective candidate set before the Wakefield association in the middle of June 1930:

Dr. Hillman concluded by saying that he was pleased that the electorate would not be asked to approve of taxes or foreign food at the next election. He was convinced that Mr. Baldwin's policy of the Referendum was infinitely more preferable ...

with the resolution passed by the South oxfordshire division on 31 May, which stated that

there is no desire for a referendum after another election: the time to appeal to the people, and to educate them to the advantage of developing the resources of the British Empire is now, as advocated by Lord Beaverbrook.

78. Rothermere to Beaverbrook, 23 June 1930, Beaverbrook MSS, C284; examples of constituencies under pressure, correspondence on Cornwall, Baldwin MSS, volume 57, ff. 59-77.

79. Wakefield CA, Council, 18 June 1930 ; South Oxfordshire CA, AGM, 31 May 1930. 
The political geography of party opinion is nowhere more apparent than in the chorus of demands emerging at this time from the south for a strong, clear, more advanced definition of policy. 80

The party leadership felt it politically suicidal to accede to these demands, aware as they were that the Labour government might collapse at any time, and bring about a general election in which an advanced policy could only be a liability and an easy target for the Socialists. As a result, Baldwin was forced to rely upon vagueness as a deliberate tactical policy, in an attempt to paper over the gulf between the different sections of his party, and the widening gap between the forward elements and the mass of public opinion. This was hardly a respectable or inspiring position, and it brought with it its own problems, for the confusion over policy in the constituencies was considerable.81 A number of leading figues in the party attempted to solve this problem by offering their own versions of the policy, and were ignored and even, in the case of Derby, tactlessly snubbed, by Baldwin for their pains: the last thing he

80. Chichester CA, Finance and GP Ctte., 28 April 1930; Chelmsford CA, Exec., 13 June 1930; Harborough CA, Exec., 26 April 1930; Oxford City CA, Finance and GP Ctte., 25 April 1930; North West Wiltshire CA, Exec., 4 April 1930; Brighton CA, Res. Of 23 June 1930 in Morning Post, 24 June 1930; West Fulham CA, Res. of 27 June 1930 , copy in Beaverbrook MSS B149.

81. Denbighshire CA, Southern Area AGM, 5 April 1930. 
desired was to restrict his freedom to manoeuvre. 82 By the beginning of May it was becoming apparent that this attempt to have his cake and eat it, by preserving the truce without paying the price in fiscal policy, was not a solution. The unsetting effects prompted the Chief Agent to write a warning memorandum to Davidson, 83 and Baldwin finally had to reveal his attitude more clearly in the series of speeches he was making between 9 May and 2 June, typically confined to northern cities, in support of the flagging "Home and Empire" campaign. Thus it was that the first of these, at Sheffield, brought Beaverbrook face-to-face with Baldwin's decision to opt for caution.

This brought into the open the second important longterm trend, the failures of Baldwin himself as party leader and as opposition leader. First and foremost amongst Baldwin's failures was his lack of grip on policy, which, whether deliberate or nor, was by the end of April having counterproductive effects. 84 By attempting not to define his position too closely and thereby give hostages to fortune, Baldwin had given the widespread impression of his backpedalling furiously, whereas it would be more accurate to describe his tactics as an attempt simply to rest on the statu 므으 of the Hotel Cecil agreement and

82. Derby to Hoare, 23 April 1930, Derby MSS, 920 DER ( 17 ) 33 .

83. Memo, Topping to Davidson, 2 May 1930, in James, op. cit., pp. 335-336.

84. Hoare to Irwin, 17 May 1930, Halifax MSS, India office EUR.C. $152 / 19 / 1 / 61$. 
resist pressure to progress further. ${ }^{85}$. The reason for this was that Baldwin had to take into acoount wider circumstances than those relevant only to appeasing the protectionists. Faced with the determined assaults of the Labour government's free trade chancellor of the Exchequer, Snowden, on the limited safeguarding duties already in existence, Baldwin instinctively adopted a defensive position with the accent on the immediate preservation of these tariffs rather than discussing their possible future expansion. Commitments to restore any duties removed formed the centrepiece of his Home and Empire campaign speeches, relegating Empire Free Trade to the indefinite future. This strategy, perhaps acceptable in the atmosphere of winter 1929 with the fear of being caught in a snap election with the "dear food" albatross, now seemed weak and inadequate. Between February and November 1930 Baldwin was to adopt in slow stages policies demanded by the protectionist section of his party, only to find that the latter had discarded their previous positions in favour of one yet futher advancement. This produced widespread dissatisfaction with his leadership because, although his views evolved, they seemed to be formed by outside pressure, not inner convictions. Rather than his leading the party to a policy of tariff reform and imperial preference, it seemed to have lead him, willy nilly, to that goal. There were, of course, strong

85. Rothermere to Beaverbrook, 6 April 1930, Beaverbrook MSS, C284. 
reasons for Baldwin's reluctance: he remembered clearly that on the previous attempts of 1906 and 1923 the food tax issue had cost the party the election. He was loath to take up such a cross again until he was convinced that if he did not do so, an even worse fate would befall the party - its fragmentation into impotent splinters. It has been said that the first duty of a Conservative leader is to preserve the unity of the party. Certainly, it was only when Baldwin was convinced that such an upheaval was the alternative would he fully countenance protection. He did so with extreme reluctance, for the electoral straws in the wind were by no means clear during 1930, and despite accumulating evidence by the end of that year of a shift in pubiic opinion away from free trade, Baldwin still believed that in a general election, when the chips were down, working class urban voters would vote for safeguarding of industries, but not for duties on food imports. Thus he cast the content of his "Home and Empire" speeches accordingly, and thus also did he disappoint his rank and file, and alienate Beaverbrook. Baldwin's position during the first half of 1930 was that of a man performing a balancing trick whilst walking on a tightrope, and it is thus understandable that wherever possible he took refuge in vagueness and confusion. On too many occasions, however, this tactic appeared to his followers and colleagues as a policy of aimless drift, and a failure of leadership. 
This deteriorating level of confidence in the Parliamentary party with Baldwin's leadership was only partly caused by his failure to provide the much-demanded 'clear lead' on policy. It was also the result of his more general weakness as a Parliamentary leader of opposition.86 Baldwin had cut a poor figure in opposition, and on no occasion succeeded in throwing of $f$ the immediate post-election attitude of giving the government the benefit of the doubt, an impression that was dampening the spirits of a party which was beginning to sense the Labour government's growing vulnerability. 87 Baldwin's inability to lead a strongly partisan assault on the government was a principal cause of complaint against him by the Diehard right wing. 88 By the middle of May dissatisfaction with Baldwin was spreading amongst backbench MPs. Inskip, meeting Headlam on the 19th, told him

that feeling in the party was bad - antagonism against JCC Davidson and annoyance with Baldwin for not taking a stronger attitude against the government in the House. Everybody appears to be at sixes and sevens.

86. N. to Hilda Chamberlain, 13 october 1929, NC $18 / 1 / 672$.

87. Derby to N. Chamberlain, 25 February 1931 , NC $8 / 10 / 21$.

88. Brentford to Salisbury, 17 April 1930, Salisbury MSS, $S(4) \quad 134 / 159$.

89. Headlam diary, 19 May 1930. 
Baldwin's failure to shine as an opposition leader was exacerbated by his aloofness from many of the younger MPs, and his frequent absences from the House during 1930.90 This remoteness was further emphasised by Baldwin's tactic of spending his time and energy during much of 1930 in platform speaking campaigns stumping the country.91 This may have been a subconscious withdrawal from the Commons as an arena in which he was doing badly, but in retrospect Bridgeman considered it to have been a tactical misjudgement:

Baldwin did not realise that the centre of discontent was in London \& the House, \& spent too much of his time \& energy in innumerable speeches \& tours about the country, instead of occupying himself with conversation with, and consideration of, the more important members of the party outside the old Cabinet, and of the rank and file of MPs. His strength exhausted itself in these countless speeches....

92

Baldwin's failure as a partisan opposition leader was fully exposed over the question of the London Naval Conference and its provisions for disarmament negotiated by the government in May 1930. Further reductions in the Navy were regarded with misgivings by much of the Conservative Party, and the proposals of the treaty, whilst arousing little criticism from the majority of

90. H. Balfour, op. cit., p. 76.

91. A. to Hilda Chamberlain, 1 June 1930, AC 5/1/503.

92. Bridgeman journal, July 1930, volume II, pp. 221-223. 
public opinion, were an anathema to the Conservative right wing. Churchill in particular adopted a position of intransigent opposition to the treaty, and his concern was echoed in the critical resolutions on the treaty forwarded from the constituencies.93 Baldwin, sensing that on this issue the party was out of touch with public opinion, followed a cautious and non-commiftal line, but this, combined with the growing dissatisfaction on other fronts, came near to causing a rebeliion on the back benches. Significantly, the opinions of the Diehard wing were echoed across an unusually wide spectrum of party opinion, and found expression in the form of the 1922 Private Members Committee, where it was decided to urge on the leader the case for a strong party protest against the treaty. The laok of central direction was exposed when eighty-eight Conservative MPs put their names to a strong motion rejecting the crucial Part II of the treaty, to find on 26 May that their leader would only make the milder criticism of asking for a Select Committee on the issue. 94

The different strands of dissatisfaction: with Davidson as Chairman, with Baldwin as opposition leader, and with the ambiguous policy expressions of both, were coming to a head at the same time as the uneasy truce was

93. Churchill to Baldwin, 17 May 1930, Baldwin MSS, volume 117, ff. 53-54; East Wolverhampton CA, Luton CA, Resolutions in NU Exec., 17 June 1930.

94. The Times, 21 May 1930; P. Goodhart and U. Branston, 
disintegrating. Neville Chamberlain assessed the position in the second half of May 1930:

.... our party is in a very disgruntled and disheartened condition. SB's speeches so far have been very disappointing... I hear that $M a x$ is thoroughly dissatisfied and rebellious... the fact is that there is a considerable amount of justification for his contention that the party is not all out for the policy. I am getting continual rumours of dissatisfaction with the leadership and if David[son] does not make his announcement [of resignation] soon I foresee an explosion... [The backbenchers] are thoroughly dissatisfied with what they consider to be want of leadership by the leader, and I take rather a serious view of their action, which looks to me like the first beginnings of a revolt.

Whilst these background themes were eroding the foundations of the truce, Beaverbrook's uneasiness had grown with the increasing intimations that Baldwin did not intend to progress beyond his present position. In parallel with this Beaverbrook's frustration mounted at the way he appeared to have painted himself into a tactical corner with the suggestion of the referendum, a suggestion Baldwin now seemed to be using, as Beaverbrook increasingly complained, "as a shield instead of a sword".96 But it took some time for the process of disillusionment with the Hotel Cecil concordat to mature in Beaverbrook, a process in any case slowed by the frenzied activity of West Fulham. His restlessness was at

95. N. to Ida Chamberlain, 17 May 1930, NC $18 / 1 / 695$.

96. Beaverbrook to Hoare, 15 May 1930, Templewood MSS, $\mathrm{VI} / 1$. 
first apparent in private conversation and correspondence, and not made public until the end of May. For, despite all the hard things he occasionally said of the party leader, it took time for Beaverbrook to lose his faith in Baldwin, and to come surprisingly reluctantly to the conclusion that it would be necessary to attack, perhaps even destroy, his position to carry the spirit, as well as the letter, of Empire Unity.

These general themes provided the setting for the final phase of the truce, in May and early June 1930. The increasing tensions underlying this last period were exposed first by the Crystal Palace speech debacle. This illustrated Beaverbrook's powerful appeal to the party grassroots, Davidson's incompetence, and the mounting counter-attack to the latter's use of leaflet 3153. Empire Day had become as much a party as a national festival, and was a common occasion for the organisation of political mass meetings. Baldwin was due to address such a rally of South London Conservatism at the crystal Palace on Empire Day, 24 May 1930, and when this was being organised in early April, the London Associations insisted that Beaverbrook should be asked to chair the meeting, in order to give it the Empire Crusade seal of approval and thus personify the truce. Davidson wrote to Beaverbrook 
on 14 April, extending the invitation to preside at the Crystal Palace, only three days after he had forwarded Beaverbrook the first copies of leaflet 3153. At this point Neville Chamberlain learned of the planned meeting, and was horrified at the tactical blunder Davidson had made in placing Baldwin and the party in the role of supplicants. He sent Davidson to see Beaverbrook, and to ask him to decline the embarrasing honour. Beaverbrook so obliged, indicating he was commited to attend the EIA Empire Day Rally in Hyde Park.97 At this point, however, the question of the Crystal Palace rally became entangled with the controversy raging around leaflet 3153 , over which Beaverbrook's anger was by now becoming known. The South London constituencies were not only generally sympathetic to the empire free trade policy, but were also more concerned than other areas not to antagonise the Press Lords, for the power of the Beaverbrook-Rothermere press was predominantly based in London and the Home Counties, where the principal readership of the Daily Express and Daily Mail was reinforced by their control of the two London evening daily papers, the Evening Standard and Evening News. London, indeed, was to be Beaverbrook's stamping ground, and consistently the region of Conservatism most responsive to the beat of his drum. At

97. Davidson to Beaverbrook, 14 April 1930, Beaverbrook MSS, C111; N. to Ida Chamberlain, 20 April 1930, NC 18/1/692; Beaverbrook to Davidson, 16 April 1930, Beaverbrook MSS, C111; Croft to Beaverbrook, 9 May 1930, ibid., C 101 . 
preliminary meeting on 23 April 1930, the London local Associations blamed Beaverbrook's refusal on the Central office and on leaflet 3153, and determined that they must secure Beaverbrook's presence if the rally was to be worth staging. 98 In addition, as the Diehard London MP Sir Philip Dawson wrote to Beaverbrook, "a resolution was passed by a large majority of those present that they would not support a meeting at the Crystal Palace unless you and Mr. Baldwin were on the platform together".99 The leadership and Central office seemed dangerously on the verge of losing control over the party altogether. By the time this request reached Beaverbrook, however, his opposition to leaflet 3153 had hardened to such a point that on this occasion he did make it the pretext for a second refusal. 100 when this was communicated to the London Association Chairmen and MPs at their next meeting on 29 April,

there was a feeling of apprehension on the part of some present that because Beaverbrook had refused to come to the Crystal Palace meeting, it would not be a success

and "a large majority" of those present decided to cancel it. This was more than a storm in a teacup, as the party's principal agent, Robert Topping acknowledged on 2

98. Memo, Topping to Davidson, 2 May 1930, in James, op. cit., pp. 335-336.

99. Dawson to Beaverbrook, 24 April 1930, Beaverbrook MSS, B141.

100. Beaverbrook to Hall, 25 April 1930, ibida, B153. 
May in reviewing the "extremely disturbing" and "most serious" events within the rank and file organisations during April.101

It is clear, however, that the final and decisive factor in the breakdown of the Hotel Cecil concordat was the content and tone of Baldwin's speeches in support of the "Home and Empire" campaign.102 With these, the negativism implicit in Baldwin's last platform address given at Manchester a month before, on 7 April, became explicit, and the truce moved into its final phase of disintegration. The most damaging of these was the first, given at Sheffield on 8 May 1930. The pitch of the address was wholly negative and defensive, opening with the very mild criticism of the government's election promises of 1929 that "many of their promises were made in perfectly good faith, but it was the good faith of ignorance". 103 The main body of the speech consisted of a defence of the threatened safeguarding duties, though Baldwin did take one step forward in indicating that safeguarding would be applied to the iron and steel industries by a Conservative government. Baldwin paid lip service to the concept of Empire Free Trade, but qualified it in three significant ways: first, by insisting that extension of safeguarding at home was somehow an essential 101. Memo, Topping to Davidson, 2 May 1930, in James, op. cit., pp. 335-336.

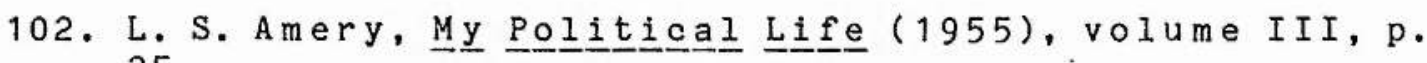
25.

103. The Times, 9 May 1930. 
first step to negotiations with the Dominions, a proposal which in practice would postpone such negotiations to the end, rather than the beginning, of a new Conservative government. Secondly, mention of agriculture was conspicuous by its absence. Baldwin's third qualification was to indicate that the referendum idea was not, as Beaverbrook had intended, a transitory phase in the evolution of party comitments on the road to adopting a position of complete freedom to impose duties when next in possession of a Commons majority - the so-called "free hand" policy. Baldwin instead spoke of the referendum as if it were the definitive and final stage of policy, promising:

I will not ask the people of this country at the forthcoming General Election to put any tax on foreign foods.

In the series of speeches which followed Baldwin gave even more emphasis to safeguarding, and less and less prominence to the question of Empire economic unity. At Reading on 14 May Baldwin declared he wanted to "begin at home", though he later added "when I said I wanted Safeguarding at home I need hardly remind you that we want it for Imperial purposes very nearly as much". 104 Thereafter the Imperial side of the policy dwindled still further from view, receiving no mention at all in Baldwin's next speech, at Middlesb rough on 19 May. 105 104. The Times, 15 May 1930.

105. The Times, 20 May 1930. 
Speaking at Bury, on 27 May, Baldwin dressed up safeguarding as a weapon along the lines of Balfour's "Retaliation" policy of 1903-1905, and explicitly warned that the economic unity of the Empire "may take a generation or more to bring about". 106 In his final speech in the series, given at Leeds on 31 May 1930, Baldwin not only failed to make any reference to Empire Trade, but also opened with a statement which revealed the line of thought which he had been following throughout his campaign:

No party can attain Power in our country today that cannot make an appeal to the North and to Scotland. It is that appeal we are making today with full confidence that in the victory which awaits us at no distant date, the North will once more play its part.

107

These speeches brought into the open the essential flaw of the Hotel Cecil concordat - the fact that peace had only been achieved through each principal's misconceptions of the aims and intentions of the other. Baldwin believed he had satisfied Beaverbrook by his commitment to calling an imperial conference, and through the political device of the referendum, had fulfilled his side of the bargain by thus dropping all the negative and inhibiting pledges which had previously ruled out most of the recommendations such a conference would be likely to make. This was not Beaverbrook's understanding of the spirit, rather than the letter, of the truce, which he had 106. The Times, May 281930 . 107. The Times, June 21930. 
al ways seen as being a first step towards a stronger and more definite commitment. Hence his dismay at Baldwin's transformation of the referendum into yet another negative and inhibiting pledge. 108 Thus Beaverbrook saw Baldwin's "Home and Empire" speeches as a betrayal of the spirit of the truce.109 After the Sheffield speech he lost confidence in Baldwin, deciding that the "referendum has falled as an instrument of policy."110 on 19 May he discussed his future plans with Elibank, who noted that "Beaverbrook has decided that he will not proceed with the Referendum, which was only a Bridge for getting his policy adopted". 111 The conclusion that it had failed led Beaverbrook logically down the path his instincts had for some time been urging, restless at his passive role, into going all out for the full crusade policy, without qualifications. On 21 May he publicly tore up the referendum, and with it the truce, in a speech at Enfield:

We must have a tariff built against foreign foodstuffs. We cannot get on without it. When any man talks about Empire Free Trade and says it may not be necessary to tax food just dismiss him. He is

108. Beaverbrook to N. Chamberlain, 20 April 1930, Beaverbrook MSS, C80.

109. Beaverbrook to Croft, 19 May 1930, Beaverbrook MSS, C 101 .

110. Beaverbrook to Hoare, 15 May 1930, Templewood MSS, VI/1; N. to Hilda Chamberlain, 25 May 1930 , NC 18/1/696; Lockhart Diary, 11 May 1930.

111. Elibank diary, 19 May 1930, f. 55. 
either a fool or a liar.... Empire Free Trade carried with it essentially and necessarily a tax on foreign foodstuffs.

This initiative only served to confirm Baldwin's suspicions of Beaverbrook's unreliability and untrustworthiness, for he perceived his own conduct as perfectly consistent with his pledges at the Hotel Cecil, and saw Beaverbrook as the wrecker of the truce and the aggressor in returning to open warfare.

The result of the breakdown of the truce was to set the two men further apart, personally and politically, than ever before. Beaverbrook turned away from the strategy of negotiation with the party leaders, to appeal deliberately to the party grassroots to force his policy on their superiors. He was aware of the popular appeal of his policy at that level, and the vulnerable and unpopular position the leaders had taken:

The Conservative Party is hopelessly divided. The rank and file is on the side of Empire Free Trade. otherwise, the leaders, who march off in the other direction, would smash me at once.

At first he looked to the backbench MPs for support, writing to one at the end of April:

112. The Times, 22 May 1930.

113. Beaverbrook to Bridgeman, 15 May 1930, Beaverbrook MSS, C133. 
The Back-benchers and those who have experience of the Back-benchers could save the Conservative Party, but it would involve showing Mr. Baldwin the way to go.

A month later, however, he had decided to direct his attention to his most likely base of popular support, in the Constituency Associations. In this he may well have been encouraged by his recent platform successes in the West Fulham by-election. "The truth is I don't care what view Members of the Commons or Lords take of this issue", he told Horne, "it is to the Constituencies that I lift up mine eyes."115 The logic of this plan of campaign, however, also included the full revival of the Crusade in all its manifestations as a separate party: the organisation of branches now went ahead, funds were appealed for, 116 and future by-elections were to be contested either by an independent Crusader, or the official nominee on Beaverbrook's unofficial platform. This path could only lead to confrontation, a confrontation in which Beaverbrook's tactios would eventually alienate a sizeable proportion of the party loyalists, whose dislike of factionalism was greater than their desire for the "free hand", and who would be

114. Beaverbrook to Macdonell, 28 April 1930, ibid., B165. 115. Beaverbrook to Horne, 28 May 1930, ibid., C178.

116. Beaverbrook to Cunliffe-0wen, 1 June 1930, ibid., C 107 . 
receptive to the traditional cries of loyalty to the leader.

At the same time as Beaverbrook was moving towards an open breach, the party leadership reduced their vulnerability by ditching the detested Party Chairman, J. C. C. Davidson. The reason for this was not that Davidson was a proxy target for assauts on Baldwin, but the reverse. Davidson's unpopularity, compounded by his blunders of the previous two months, was such that Baldwin's continued loyalty towards him was in fact in danger of dragging the Leader down with his Chairman. ${ }^{117}$ Indeed, Davidson's departure did not occur at Baldwin's instigation at all. Significantly, it was Neville Chamberlain who determined to take himself an initiative, which Baldwin might never have taken, in order to remove a man he considered both useless and a dangerous liability to all the party leadership. ${ }^{118}$ Chamberlain was becoming more involved - and more interested - in the workings of the party's central organisations, having taken over the new Research Department from Lord Eustace Percy on his return from East Africa in March. He described it as "an

117. Headlam Diary, 5 February 1930.

118. Weekend Review, 17 May 1930, copy, in Davidson MSS. 
important body" and that "through my new department I shall have my finger upon the springs of policy".119 However, he soon became aware that Davidson's position and incompetence - were frustrating all his plans, and almost immediately determined to secure his removal. Before this could be proceeded with, the inevitable problem of who was to succeed Davidson needed to be solved. At first Chamberlain did not consider himself for the position, preferring instead to secure the place for a nominee of his own, as a front through whom he could properly control the details of day-to-day organisation. Chamberlain found such a figure in the person of Geoffrey Ellis, an influential figure in the Yorkshire Provincial Area, who had lost his seat in 1929. Chamberlain kept his plans secret, and in the first week of April over lunch bluntly told Davidson:

he had better go before he was forced out... the more I see of his work the more I am convinced that in his present position he is a danger to the Party... David[son] himself said he thought he had better go: the difficulty was to find a successor. But to that I merely replied that that was S. B.'s job... I must keep up the drive if the change is to be accomplished.

This proved to be the case, for Davidson began to use the question of a successor as an excuse to delay the announcement of his going, and finally suggested that in

119. N. to Ida Chamberlain, 22 March 1930, NC 18/1/686. 120. N. to Ida Chamberlain, 4 April 1930, NC 18/1/689. 
the growing crisis of late May that it might be better for him to remain at the helm. In fact, as far as Chamberlain was concerned, the deteriorating situation made it all the more urgent for Davidson to go, and in the last week of May he saw Davidson again, determined to end the long period of indecision, and bluntly asked him

when are you going to announce your resignation... I did not mince words, and he promised that the announcement would be made before the end of the week.

121

The announcement of Davidson's departure was only one side of the coin of the attempt to appease dissent within the Party. However, with the question of his successor unsettled, and the suspicions that any nominee would probably be another Baldwinite yes-man, the party was still in an unsettled condition. Nevertheless, the fall of Davidson was the first stage in the process whereby, in the uncertain atmosphere of June 1930, the initiative passed from Beaverbrook to Baldwin and the party leaders. As the truce disintegrated in the first three weeks of June, they prepared their counterattack.

121. N. to Ida Chamberlain, 25 May 1930, NC 18/1/696. 


\section{CHAPTER 4}

\section{The Partyy Meetings and thene Party Cris Ju1y to october 1930}

Until the Home and Empire campaign, the Empire Free Traders had sought to coerce Baldwin, sensing his squeezability, by the twin-pronged strategy of an assault on the influence of Free Traders or 'pessimists' among his colleagues and confidants, and by capturing from beneath his feet the support of party rank and file. Yet, despite the success of both pincers of this strategy in the spring of 1930 , it had nevertheless failed in its ultimate aim of capturing Baldwin, and thereby securing the official party policy-making process. The Conservtive Party was not organised on democratic lines in terms of decision-making, but rather had evolved as a deference structure, with policy being handed down from above, rather than made from below by the Party Conferences or the democratically elected regional Councils. Even the Executive and Council of the National Union were forums for the deliverance of party policy, not for its formulation. The decisionmaking process could only be controlled from above; although it could be influenced on occasion by the Parliamentary party, it could not be captured from outside or from below without involving a complete restructuring of the distribution of power and a reallocation of the roles of leaders and led. The constituency parties held power, but it was a negative power; a residual power of the last resort to revolt and smash the party if driven 
too far. Strong pressure from below was likely to have some effect on the party leadership, but unless it was complete, nation-wide, consistent and representative it would not alone ensure success for the popular policy advocated by Beaverbrook. For the tradition of party loyalty was extremely strong, and a campaign to oust the leader, particularly if conducted by the press, was likely to alienate as many supporters as it attracted, and even in the end to produce a backlash in Baldwin's favour whioh would shore up his crumbling credibility. This difficult situation produced a period of tactical uncertainty in the Crusade camp, where the dilemma was all the greater in that they sought not to fight the Conservative Party, but to work with and through it. After May 1930 the press lords veered between hoping that Baldwin could still be forced to co-operate against his will, to attempts to destroy his position altogether. That lack of consistency was to prove one of the fundamental weaknesses of Baldwin's opponents, revealing as it did instinctive inhibitions of party loyalty that to a greater or lesser degree held back Amery, Croft and Elibank from the unrestricted hostility of Beaverbrook and Rothermere. For with the end of the truce in June 1930 the period of attempted conciliation on the part of both sides was not in fact replaced by all-out hostilities; bouts of negotiations, though all ultimately fruitless until those of March 1931, indicated that the press lords had not resolved their tactical problems. 
The first half of June 1930 marked an "uncomfortable" stage in which both sides drifted yet further apart, having tacitly scrapped the truce but not yet having moved into the logical corollary of open and public confrontation. 1 Typically, it was the impatient Beaverbrook who took the initiative, a decision which in fact placed him in a poor tactical position. He lost much credit for dropping the referendum, partly because he was seen to be the demolisher of the bridge of unity which the referendum had represented, and partly due to his apparent inconsistency in having been himself the initiator of the referendum proposal. 2 The result was a polarisation of conservative opinion around the two protagonists in the second half of June, stimulated by three events which combined to place Baldwin for the first time in an advantageous position from which to launch a counterattack. The first of these was the unveiling of the much-heralded official policy pronouncement on agriculture, in a speech given by Baldwin to a massed open-air rally at Glemham Park 9 June. Under the cover of a blanket statement that protection must be ruled out as a solution, Baldwin moved a considerable distance in the farmers' direction on specific matters. Once again

1. A. Lane-Fox to Irwin, 17 June 1930, Halifax MSS, Borthwick Institute, A2/278/6/2; Lockhart Diary, June 121930 .

2. Bridgeman to Irwin, 15 June 1930, Halifax MSS; India Office, Eur.C. 152/19/1/79. 
calling his plan "Safeguarding", he profjerred a guaranteed price system for cereal growers, and appeased their principal grievance by claiming a "free hand" to stop the dumping of foreign subsidised foodstuffs "by prohibition or countervailing duty". 3 The importance of this speech, coming at the time it did, can hardly be over-emphasised. In one stroke it both significantly closed the gap in the major area where party policy was well out of step with its supporters, in the agricultural seats of the south, southwest and East Anglia; whilst at the same time sidestepping the issue of Empire Free Trade and avoiding the appearance of a concession to Beaverbrook. This was underlined by the favourable reception given to Baldwin's pronouncement by the National Farmers Union, of whose response the leader writer of The Times commented, "Never, in short, has any declaration of agricultural policy ... been received by the farmers with such marked expressions of approval." 4

The second event was in part a product bf Baldwin's explicit disavowal of food taxes at Glemham Park, for Beaverbrook mistakenly seized upon this as a suitable peg on which to hang his repudiation of the reférendum, and the recommencement of hostilities. On 17 June he published a letter in the Daily Mail which announced the

3. The Times, 11 June 1930.

4. Ibid. 
renewal of the Crusade as a separate party, and aimed a blow at the Conservative Party as a whole by appealing for supporters to divert their subscriptions from their local Associations to the crusade. Tactically this was a counterproductive move, for the assault on the party provoked resentment amongst moderates and waverers on the councils and executives of local associations, and went some way to arresting the gradual slide of many southern local parties to the Crusade camp. Beaverbrook's move. gave a moral advantage, in the form of appeals to party loyalty, to the Baldwinites, and by pushing moderate protectionists into the official camp in this manner, isolated rather than assisted the whole-hoggers. This was very evident in the reactions of the Executive Committee of the National Union, which was meting on 17 June. Despite the opposition of two right-wing members, who significantly failed to find backing, the Executive passed a resolution condemnatory of Beaverbrook's letter. ${ }^{5}$ This reaction from the elected body of the local associations indicated to Baldwin that the Crusaders might now be wrong-footed and vulnerable to a counter-stroke.

The third event which polarised party opinion in Baldwin's favour was the resolution of the problem of the vacant Chairmanship in a manner satisfactory to the rank and file. Although the ditching of Davidson had considerably reduced the leadership's collective

5. NU Exec., 17 June 1930. 
unpopularity, the long delay in the announcement of a successor was itself a destabilising factor. Numerous names were canvassed, including Walter Elliot, Kingsley Wood, and the chief whip, Eyres Monsell. Even more alarming was the growing demand that the Diehard George Lloyd be appointed. By 20 June, petitions were circulating among MPs, one in favour of Lloyd and another in favour of Leslie Wilson, and "both carried with them a condemnation of the long delay". 6 It was in this atmosphere that Hoare suggested to Chamberlain

what I have rather been feeling myself, that Elis hardly carries guns enough to stand the fire that will be directed at him if he stands alone.... [Hoare suggested] I should be Chairman for a limited period with Ellis as understudy. I am inclined to give serious consideration to this idea ... there would be some guarantee that the job would be done.

7

Baldwin, however, preferred the idea of asking Bridgeman, who was also of ex-Cabinet rank and respected in the party at large, and personally much closer to him. As the position was in Baldwin's gift, Chamberlain could not prevent this move, and consoled himself with the thought that "his name will be suitable and he will keep out the Leslie Wilson's and George Lloyd's. I shall bide my

6. N. to Hilda Chamberlain, 21 June 1930, NC 18/1/701.

7. N. to Hilda Chamberlain, addendum to letter of $25 \mathrm{May}$ 1930 , NC $18 / 1 / 697$. 
time." 8 In the event, Bridgeman refused the post, leaving Baldwin in a dilemma from which the acceptance of Neville Chamberlain himself seemed by far the lesser evil.9 Baldwin appreciated that the appointment of Chamberlain would be popular with the rank and file. Indeed, the chief whip had described Chamberlain as the "one man who could really completely restore confidence and pull the whole thing together". 10 This was, of course, precisely the effect Baldwin was looking for. Chamberlain recorded the resolution of the problem in his diary:

at last everyone seems to have come to the conclusion that I am the one man whose name would command general confidence, and rather reluctantly $S$. B. asked me to take the place.

Baldwin's reluctance was not the product of any fear of Neville Chamberlain as a rival, but was merely his characteristic vacillation and difficulty in arriving at a decision on important matters. Baldwin needed a loyal lieutenant whom he could trust in the important position of Party Chairman, and Neville Chamberlain fitted this bill as well as anyone after Davidson and Bridgeman. Baldwin could not fail to be aware of the community of

8. N. to Hilda Chamberlain, 8 June 1930, NC $18 / 1 / 699$.

9. Bridgeman to Baldwin, 18 June 1930, Bridgeman MSS, SRO $3389 / 94$.

10. N. to Hilda Chamberlain, 21 June 1930, NC $18 / 1 / 701$.

11. N. Chamberlain diary, 22 June 1930, NC $2 / 22$. 
feeling he shared with Neville Chamberlain in the matter of the detested Lloyd George coalition - still a crucial political litmus test 12 - and also in the matter of the Irwin Declaration on Dominion status for India. Equally, Chamberlain had shown little real desire during six years of high office to take up his father's mantle in the form of advocating the food tax. Above all, Baldwin was correct in his appreciation of Chamberlain's emotive, as well as merely pragmatic, loyalty to the leader and horror of party intrigue, well summed-up in the famous analogy that "S. B. is my friend as well as my Leader, and I would not on any account play L[loyd] G[eorge] to his Asquith."13 Chamberlain fitted the need to reasure the party, for he was not looked on, as Davidson had been, as a personal crony of Baldwin, but was clearly a front-rank figure in his own right. This appointment, together with the concession that under its new rules the National Union would select its own Executive Chairman rather than having the Central office Chairman thrust upon it, went a long way to appease the resentments voiced since the election defeat.

These three events did much to produce a rally to the leadership during the second half of June, and they were

12. As seen by the fact that Leslie Wilson's role in 1922 could still determine his acceptability as Chairman; Bridgeman noted "the old Coalitioners hate him" Bridgeman to Irwin, 15 June 1930, India Office Eur.C. $152 / 19 / 1 / 79$.

13. N. to Hilda Chamberlain, 26 October 1929, NC $18 / 1 / 674$. 
further stimulated and supported by a swelling background chorus of disapproval from all ranks in the party of the pretensions and methods of the press barons.14 The identification of the press lords as challenging parliamentary power inevitably encouraged a rally to Baldwin who, whatever his other defects, could be trusted firmly to defend the constitution. The Baldwinite MP Waldron Smithers' view was far from unusual; condeming the "unfairness and un-English methods" of the press, he declared:

This power of the press is a new factor in our national life and must be fought even if some of us founder in the fight .... deep down in the hearts of English men and women remains still the spirit of fair play which activated them in 1914 and in the General Strike of 1926. The truth will prevail in the end.

These maturing feelings, shared by Baldwin himself, represented the foundation on which he was to increasingly rest his efforts in the propagandabattle for the hearts and souls of the party. It enabled him to present the debate in much more favourable terms to his own position,

14. Middleton and Prestwich CA, AGM, 1 March 1930; Res. from Middlesex Prov.Div., NU Exec., 16 July 1930; Croft to Beaverbrook, 28 June 1930, Beaverbrook MSS, C101; Lyne (prospective candidate for Bristol Central) to Beaverbrook, 27 June 1930, ibid., B164.

15. Smithers to Salisbury, 19 August 1930, Salisbury MSS, $S(4) 136 / 148$. 
for instead of being a disagreement over fiscal policy, it was to be presented as a challenge to the very nature of the parliamentary constitution. Thus Baldwin deliberately ignored the rank and file support for the idea of Empire Free Trade, and sidestepped it completely by focusing his attention on the press lords' role in politics. In this he exploited Beaverbrook and Rothermere's failure to persuade any significant parliamentary figure to act as the nominal leader of their campaign. From being a battle over political programmes, where Baldwin was of necessity on the defensive if he was to retain a policy acceptable to northern urban electors, it now became also a battle over political methods, with Baldwin on the offensive. The events of June 1930: the Gle e/ham Park agricultural policy; the miscalculation made by Beaverbrook in his manifesto of 17 June; and the appointment of a strong and popular Chairman, together with increasing tensions in the attitude of the party to the popular press, formed a combination of factors from which a counterattack could be launched.

The fact that the initiative had now passed to the leadership was swiftly capitalised upon by the decision to call a party meeting. Sensing the opportunity provided by the new mood in the party, the decision was taken on 19 June to summon a party meeting at the Caxton Hall, Westminster, for 24 June. Furthermore, the announcement of Chamberlain's acceptance of the Chairmanship was to be 
carefully timed for the eve of the meeting. 16 The situation was such as to give rise to complete confidence that at such a gathering the critics could be outmanoeuvered and out-trumped by the appeal to party loyalty, by attacks on the press per se, and by mobilising the anti-food tax sentiments still held by many MPs and almost all the prospective parliamentary candidates. To them indeed the referendum, whatever its defects, represented a shield against the electoral unpopularity of the dear-food cry. The idea of a party meeting had been in the air amongst the shadow cabinet for some time, as a move to pre-empt Beaverbrook's rumoured plan to agitate for a special conference of the National Union.17 The party meeting was to be a much more favourable forum for the leadership, and by carefully deciding that it should consist only of MPs and candidates, and not peers, it was by longstanding precedent effectively limited to the discussion of policy and not leadership. Baldwin explained to Salisbury that

my idea has been to call together those who are actively engaged in the constituencies as members or candidates, and not to summon a party meeting in the accepted sense of the term... the question of leadership, according to ancient practice, is as I understand a matter for Lords and Commons alone.

16. N. to Hilda Chamberlain, 21 June 1930, NC $18 / 1 / 701$.

17. Bridgeman to Baldwin, 22 June 1930, Baldwin MSS, volume 165 , ff. $28-29$.

18. Baldwin to Salisbury, 23 June 1930, Salisbury MSS, $S(4) 135 / 184$. 
At the Caxton Hall meeting Baldwin produced one of his periodic oratorical triumphs. In a devastatingly phrased onslaught, he switched the issue from the press lords message to the medium itself, and out-trumped them by playing the constitutional card. In this gambit he was, ironically, aided by the maladroit manoeuvres of Beaverbrook's ally, Lord Rothermere. By focusing his specific criticisms on the more vulnerable and least popular of the press barons, Baldwin was effectively able to damn Beaverbrook by virtue of the association. The issue at stake was elevated by Baldwin to an altogether different plane from that of food taxes: the press lords, he claimed, had

\footnotetext{
the desire to dictate the policy to a big party, to choose a leader, to impose ministers on the crown: the only parallel to that was the action of the TUC in $1926 \ldots$ the challenge has been issued... I accept, as I accepted the challenge of the TUC.
}

Thus were the press lords effectively bracketed with the General Strike in their pretensions to dictate to Parliament. Having set the atmosphere, Baldwin then produced a letter written by Lord Rothermere to the protectionist MP Hannon. Although Rothermere had intended the letter as a semi-public statement of his position in any negotiations for peace, it was truculent and dictatorial in tone, and as a result of incautious phraseology, potentially damning in content; it gave the impression that Rothermere demanded not merely to know the 
names of future members of any Baldwin cabinet, but also implied a right of approval over policy and veto over personnel.19 Hannon, acting in his role of mediator between R'othermere and the leadership, had shown the letter to Davidson, who informed Baldwin of its existence. 20 Baldwin, realising its potential use, sent for Hannon on 21 June and asked for the letter. 21 The effect of this document, when read by Baldwin at the Caxton Hall, was dramatic, producing amongst his audience "a white heat of indignation". 22 In the light of this, a rally around the leader was inevitable, and consideration of the problem of dropping or keeping the referendum policy was swept aside. A resolution proposed by Gretton and Page Croft to drop the referendum and go for the free hand, although it carefully avoided the entire issue of leadership, was rejected by a large majority of the meeting. The decisive speech against it was made by sir Robert Horne, a figure who possessed much credibility amongst the tariff reformers. Horne dismissed the debate on policy as an academic irrelevance to the main issue, and while indicating his own desire to drop the

19. The Times, 25 June 1930; J. Green, Mr. Baldwin Study in Post-War Conservatism (1933), p. 229 .

20. Hannon to Beaverbrook, 12 September 1955, Hannon MSS $17 / 1$.

21. Hannon, 'Secret Memo', dated 21 June 1930, Hannon MSS $17 / 1$.

22. Lane-Fox to Irwin, 25 June 1930, Halifax MSS, India office Eur.C.152/19/1/87. 
referendum stated firmly that to do so or even to appear to do so at the dictation of the press was utterly impossible.

In terms of personality, the result of the Caxton Hall was a clear-cut triumph for Baldwin over his challengers. In terms of strategy it also represented a victory for Baldwin, for the meeting accepted the logic of his argument that the constitutional issue transcended the policy issue. However, in political terms the result of the meeting of 24 June was much more ambiguous. This was especially the case as far as the referendum was concerned. It remained the official definition of party policy, and was still looked on as the only practical course in many northern local associations.23 Even in southern associations the growing dislike of the policy was counterbalanced by the appeal of loyalty to the leader. 24 However, the concept was increasingly viewed as discredited among London political circles. Amery wrote to Baldwin after the meeting that everyone "felt that the Referendum had got to be dropped when you can find a convenient opportunity".25 In fact, the party meeting was not a long-term solution to the problems facing Baldwin. One reason for this was that its verdict had been written

23. York CA, Special Exec., 1 July 1930; Northern Herefordshire CA, Advisory Ctte., 4. July 1930; Wakefield CA, Council, 18 June 1930.

24. Oxford City CA, Chairman's remarks at Finance and GP Ctte., 26 June 1930.

25. Amery to Baldwin, 4 July 1930, Baldwin MSS, volume 31 , ff. 133-134. 
off in advance by his challengers who, calling it a "packed" and "stage-managed" affair, proclaimed that "it will not satisfy those who are pressing for a stronger fiscal policy". 26 Even Austen Chamberlain commented that "though the party meeting was a necessary and useful gathering, it really settled nothing." 27 Baldwin had won a battle, but not the war, and the meeting served only as a successful holding action, intended to last until the Imperial Conference due to convene in the autumn, which was widely expected to provide a suitable pretext for changing policy. 28 However, the erosion of the limited success achieved by Baldwin at the Caxton Hall on 24 June occurred much more rapidly than this strategy allowed for, with the result that the nadir of the Party's fortunes was reached in September 1930, before the Imperial Conference opened.

This erosion was the product of a series of factors, all of which tended to undermine the acceptability of the Caxton Hall decision. Of these, one of the most significant was Baldwin's continued failure to provide satisfactory leadership. After the Caxton Hall meeting and the burst of activity which accompanied it, he seemed to relapse once again into a mood where lethargy and complacency were mixed, a mood that lasted until his rude 26. Daily Mail, 23, 24 June 1930.

27. A. to Hilda Chamberlain, 30 June 1930, AC 5/1/508; Observer, 29 June 1930.

28. Lane-Fox to Irwin, 25 June 1930, Halifax MSS, India Office, Eur.C. 152/19/1/87. 
awakening on his return from holidaying at Aix in late September. The principal complaint against Baldwin continued to be his failure as a leader of the opposition in the House of Commons. Even loyal MPs were complaining that "he neither makes nor seizes parliamentary opportunities", 29 and Lane-Fox commented that "there is a good deal of discontent among Conservatives who are certainly finding SB's leadership rather uninspiring." 30 By the end of the parliamentary session in July there was "very grave discontent with S. B.", wrote Austen Chamberlain: "All of us are getting fed up".31 This declining morale of the parliamentary forces inevitably filtered down to the rank and file, and rendered the seemingly more vigorous approach of the Crusaders all the more attractive by comparison. Baldwin failed to recognise the genuine appeal the Empire Free Trade ideal had for his supporters; or, if he did recognise it, failed to respond. Instead, bending over backwards in his efforts to satisfy the prejudices of the electorate in the

29. Hope to N. Chamberlain, 3 July 1930, NC $7 / 11 / 23 / 6$.

30. Lane-Fox to Irwin, 21 August 1930, Halifax MSS, India office, Eur.C. 152/19/1/120.

31. A. to Hilda Chamberlain, 28 July 1930, AC 5/1/509. 
industrial counties of the North, he seemed to be retreating even from the referendum policy, rather than preparing to advance beyond it. The ambiguities of Baldwin's speeches in July and August were tactically wise considering the fact that "the government are very tottery and ... they might fall before the end of the month", 32 and that in any ensuing general election the dear food cry would be almost the only weapon that Labour and Liberals could use to defend the seats gained from the Conservatives in 1929. But viewed from the angle of internal party tensions, these pronouncements were yet another element adding fuel to the flames of disenchantment. These were, in any case, being well stoked by the continual sniping of the Beaverbrook and Rothermere press, which was slowly having its effect on the party. One MP noted:

the course of the Conservative Party, with a Central office that is just going through reconstruction, and a leader and a policy so buffeted, is not very steady.

Amongst the inevitable consequences of this failure of leadership was a tendency to factionalism in the party.

32. Amery to Beaverbrook, 10 July 1930, Beaverbrook MSS, C5.

33. Lane-Fox to Irwin, 2 July 1930, Halifax MSS, India Office, Eur.C. 152/19/1/90. 
Page Croft took the initiative in forming in mid-July a new body, the Imperial Economic Unity group, intended to be more assertive than the EIA, and sixty-three MPs from the right of the party attended the inaugural meeting. 34

That the situation did not deteriorate further or faster during July and August 1930 was the result of the cautious approach adopted by Beaverbrook, on the urging of Amery and Page Croft. Beaverbrook was stili torn by his tactical dilemma: wishing to capture Baldwin, yet fearful of being caught by him instead; reluotant to separate himself from Rothermere, yet reluctant also to commence full-scale warfare. Beaverbrook spent the summer casting about from one line of approach to another, oscillating from co-operation through neutrality to eventual hostility. In the period immediately after the Caxton Hall meeting Beaverbrook followed the tactic of parallel co-operation with the party, whilst continuing to advocate an unrestricted food tax policy. This position was partly forced upon him by the circumstances of the North Norfolk by-election in progress during July 1930. The local Association attempted to preserve a precarious unity, declaring that their candidate "should fight on the official policy of the party and should loyally support Mr. Baldwin", but welcomed the platform co-operation of "Beaverbrook and the Empire Free Trade Crusade, which will

34. Hannon to Beaverbrook, 14 July 1930, Beaverbrook MSS, C154. 
have the whole-hearted support of [the candidate] and all that it implies." 35 In practice, the candidate fought on "the pure gospel of Empire Free Trade",36 a tactic to which the party leadership turned a blind eye. In fact, North Norfolk was not promising territory for the Crusade; the seat had never been held by a Conservative in its forty-five year existence. Despite the vocal support of the local branch of the Farmers' Union, it could not sway the longstanding Radical allegiance of the farm labourers, and the Labour candidate, significantly, won on a platform of denouncing Conservative food taxes. The failure to capture North Norfolk was a severe blow to Beaverbrook's confidence. "I do not feel at all happy about North Norfolk", he wrote; "I went in in the expectation of winning it, but we were beaten... I was under the impression that our policy would sweep the constituency." 37

The immediate consequence of this setback was to take the wind out of the Crusaders' sails, and encourage a return to the negotiating table. Neville Chamberlain, anxious to build on his position as party chairman, extended an invitation to negotiations in mid-July, which was accepted. In the early phase of these negotiations

35. North Norfolk CA, Res. of General Council, in The Times, 19 June 1930.

36. Beaverbrook to Astor, 6 July 1930, Beaverbrook MSS C14.

37. Beaverbrook to Amery, 12 July 1930, Beaverbrook MSS C5; Beaverbrook to Macmillan, 12 July 1930, ibid., C236. 
Beaverbrook's attitude, that there was "a common purpose", although "methods differ", and "a reconciliation is possible", encouraged in Chamberlain high hopes of a satisfactory outcome. 38 The terms offered, however, seemed increasingly unattractive to Beaverbrook in his changing moods of the last week of July. 39 Two related factors intervened to complicate the path of negotiation. The first of these was the advent of a by-election in the Bromley constituency, which was safe Conservative London suburbia and thus ideal Crusading territory. The second was the influence exerted by Rothermere to abandon negotiation for an all-out trial of strength; in particular, to put the matter to the proof by, for the first time, running an independent challenger to the Conservative nominee in the Bromley vacancy. Beaverbrook was reluctant to follow this course, on the advice of his Conservative fellow-travellers, but he also believed that any settlement which did not include and satisfy Rothermere would be worthless. He sought to find some via medㅡㅁㅡ between these two positions, and believed he had found it in the suggestion of Rothermere's son, Esmond Harmsworth, as official nominee for Bromley, presumably advocating a highly unofficial policy.40 Upon

38. Beaverbrook to Londonderry, 21 July 1930 , ibid., C224; N. to Hilda Chamberlain, 16 July 1930, NC $18 / 1 / 704$.

39. Beaverbrook to Bowker, 8 August 1930, Beaverbrook MSS B132.

40. N. to Ida Chamberlain, 26 July 1930, NC18/1/705. 
these contradictions, the negotiations foundered in an atmosphere of mutual suspicion. Beaverbrook could not understand that to acoet Esmond was a political impossiblity for the party leadership, and infuriated Chamberlain by his continual refusal to take no for an answer, and by further maladroit attempts to foist Esmond on him. 41 These culminated in a disastrously unsuccessful meeting between Rothermere and Chamberlain on 26 July. From this low the conversations briefly recovered, so that by 30 July Chamberlain believed he had reached an informal short-term agreement with Beaverbrook over Bromley. 42 However, Beaverbrook, finding that he could not restrain Rothermere from running an Independent at Bromley on his own account, lost his nerve, deciding that he could not afford to separate himself from his only powerful ally. The manner and timing of this sudden decision left Neville Chamberlain bitterly resentful, convinced that Beaverbrook had been simply stringing him along, and had now betrayed the trust that Chamberlain had bestowed upon him. The resulting alienation of Chamberlain, who concluded that "the man is a crook after all", was a serious error on Beaverbrook's part in the long term. In the short term, it provoked Chamberlain into a swift and hostile response:

41. N. Chamberlain diary, 25 and 29 July 1930, NC $2 / 22$. 42. Ibid., 27 and $30 \mathrm{July} 1930$. 
I had given my trust and it had been abused and I was bitterly humiliated and outraged. However, it was a time for action rather than lamentation. I went straight back to my colleagues and told them it was war...

Chamberlain made it clear to the Bromley Association Executive the next day that Esmond Harmsworth would be totally unacceptable, and adroitly turned them against Beaverbrook. The nomination of a loyal candidate, E. T. Campbell, who was also known as almost an Empire Free Trader on policy, was the cornerstone of this response. The running of Campbell by the Bromley Conservatives provided Beaverbrook with an insoluble dilemma. Rothermere in reply had brought forward under the banner of his United Empire Party an Independent, V. Redwood, who was not only a stranger to the division, but also a paid employee of Rothermere's, and of dubious political background. Beaverbrook was hesitant to nail the Empire Crusade colours to the mast of such an unattractive vessel, fearing the consequences of another disappointing showing in the ballot boxes.

Beaverbrook was encouraged to stand aside from the Bromley fight by the repeated urgings of Amery, Page Croft and Hannon, all of whom declared that Campbell was so close to the desired position in both private sympathy and public pronouncements that he should not be

43. N. Chamberlain to his wife, 30 July 1930, NC $1 / 26 / 433$. 
opposed.44 Beaverbrook resolved his problems by withdrawing from any active role in the contest, and physically distancing himself by returning to the South of France. ${ }^{45}$ His inactivity lasted into september, for on his return Beaverbrook fell ill, and was confined to bed for several weeks. Redwood fought on a wide-ranging Diehard platform of industrial protection, subsidies for farmers, economy in government spending, firm rule in India and Egypt, and no relations with Soviet Russia, as well as Empire Free Trade; though Campbell held the seat, Redwood was only three thousand votes behind. 46 Indeed, Campbell fended of his challenger only by the expedient of going "a good deal further" than official policy, which "undoubtedly gained me a great many votes". 47 This reflected not merely the opinions of insulated southern suburbia, but an evolution of Conservative opinion running across the party as a whole during the late summer and autumn of 1930. Ormsby-Gore, analysing this process, detected "a general swing to the right throughout the Tory

44. Croft to Beaverbrook, 2, 4, 22, 28 August 1930, Beaverbrook MSS, C101; Hannon to Beaverbrook, 21 and 29 August 1930, Hannon MSS $18 / 3$.

45. Beaverbrook to Bowker, 31 August 1930, Beaverbrook MSS, B132.

46. Redwood's Election Address, copy ibid., B216.

47. Report on Bromley By-Election, Campbell to Bowyer, 15 September 1930, Baldwin MSS, volume 51, ff. 13-15. 
Party, not merely in a protectionist direction, but all along the line." 48

One product of this was that the demand for dropping the referendum, expressed in resolutions suoh as that passed by forty-two Conservative MPs of the Imperial Economic Unity Group in late July, was finding increasing support far beyond the confines of the protectionist right wing. 49 The referendum had never been popular in the South; the new factor was the advance in protectionist sympathy of the industrial North - away from the referendum which had been designed only to meet its supposed prejudices. In June 1930 Conservative opinion in the North, despite having moved a considerable distance away from Free Trade during the previous year, via the ambiguous strategy of safeguarding, still remained firmly against any food tax.50 The stimulus for this advance, and for the further large strides taken by Northern opinion in the months after June, was the pressure of the slump and its consequent steep rise in unemployment, not the pressure of the Crusade, which carried little weight north of the River Trent. As the economic picture darkened in the second half of 1930, the attractiveness of insular protection acoordingly increased. The result was

48. Orm.sby-Gore to Irwin, 3 July 1930, Halifax MSS, India Office Eur.C. 152/19/1/91a.

49. Imperial Economic Unity Group, Res. of 20 July 1930 , Hannon MSS $18 / 3$.

50. Derby to Oliver Stanley, 26 June 1930, in R. Churchil1, Lي을 Derㅡy $(1959)$, p. 582 . 
that by september, for perhaps the first time in the party crisis, the sentiments of the South were finding an echo, rather than a contradiction, in the North. Though still possessing a residual and instinctive unease over food taxes, the shift in opinion was marked. With this change, the referendum policy became politically redundant. The new face of the North could be seen in the resolutions passed by the Council of the Yorkshire Provincial Area at the beginning of october, of the Scottish Unionist Association in mid-September, and by local Associations such as Don Valley; all called for an end to qualifications and reservations, and accepted "Imperial Preference with all its implications" which "should include import duties in this country on foodstuffs produced outside the Empire". 51 The transformation was both paralled and symbolised by Lord Derby's conversion to food taxes, which by october he was advocating publicly. The consequence of this was that a substantial and serious rift was opening between the polioy to which the leadership was committed, and that which the party as a whole desired to see advocated, that "the leaders of the Party should drop the question of a Referendum and press forward a policy for a Free Hand to foster and build up

51. Don Valley CA, Res. NU Exec.. $16 \mathrm{July} 1930$; on Scottish opinion, Ford (President of SUA), to Baldwin, 10 September 1930, Baldwin MSS, volume 31, ff. 151154; SUA Central Council Exec., 10 September 1930; Yorks. Prov. Area, Council, 4 October 1930. Some doubts still remained in Liverpool, Sir T. White (Chairman of Liverpool CA) to Baldwin, 1 october 1930, Baldwin MSS, volume 51, f.91. 
Empire Trade".52 This sentiment was typical of the insistent chorus of similar demands across the length and breadth of the party grassroots.53 such uniform pressure would be not only difficult but also very dangerous to resist and deny for any long period. This situation was not the creation or the result of the existence of Beaverbrook's Crusade, except in a marginal sense, but it was a situation which the crusade could readily exploit. Beaverbrook sensed his opportunity, writing in sepember that

the issue of duties on foreign foodstuffs is far past the control of $\mathrm{Mr}$. Stanley Baldwin and Mr. Neville Chamberlain now. They cannot carry their constituencies unless they swallow the pill.

The tensions within the party as a consequence of both the serious and widening rift on policy and the more general loss of confidence in the abilities of Baldwin since the election defeat combined to produce in September 1930 a party crisis of an explosive and 52. Wells CA, Exec., 11 September 1930.

53. Horncastle CA, Finance Ctte., 1 August 1930; City of London CA, AGM, 12 July 1930; N. W. Wilts. CA, Exec., 27 June 1930; Norwich CA, Finance and Advisory Ctte., 29 September 1930; Cambridgeshire CA, Res. in NU Exec., 14 October 1930; Hendon CA, Exec., 11 July 1930, copy in Beaverbrook MSS, B155; West Lewisham CA, Council, 6 October 1930, ibid., B233; South Teddington CA, 23 September 1930, and Stanwell CA, 13 October 1930, copies in Baldwin MSS, volume 165, ff. 27.6-290.

54. Beaverbrook to Williams, 24 September 1930, Beaverbrook MSS, C324. 
potentially disastrous nature. This, in fact, was to be the lowest phase of the leadership's fortunes, and the period in which its support amongst the rank and file slipped to its lowest ebb during the entire period in opposition. Despite the more superficially spectacular challenges mounted to Baldwin in the spring of 1931 , his position was never to be so weak again as it was in September and early 0ctober 1930. In this period the party came to the very brink of internal clollapse, far more serious than the buffetings it received from the press lords in February and March 1931. Indeed, the crisis of september 1930 was as threatening as the rebeliton which overthrew the leadership of Austen Chamberlain and the Coalition in 1922, and far more so than the revolt over India in 1933-35. Although the revolt was averted, its force and the extent and range of feeling behind it came from a much larger proportion of the party than any other crisis, even that of 1922. Despair affected all levels, high and low. Most serious of all were the signs of disintegration and collapse, on a scale unparalleled even with that of the Coalition period, in the local Associations.55 By the end of September 1930 the grassroots of the party were within a hair's breadth of breaking out in open revolt, and the control of the leader and Central office was on the brink

55. N. Chamberlain to Bridgeman, 5 october 1930 , Bridgeman MSS, SRO $3389 / 98$. 
of "complete collapse".56 This was exemplified by a lengthy debate consisting in the main of an open assaut on the party leadership, and revealing the chaos prevalent amongst local Executives, in the St. Alban's Association. This was all the more remarkable for the fact that it occurred in the presence of the Association President, Lord Salisbury, to whom none of the usual deference was displayed.57 Elsewhere the solidarity of lool Conservatism was falling apart. In Blackpool three local councillors and the former Unionist MP Sir Lindsay Parkinson seceeded to set up an Empire Crusade branch, complaining of "the shilly-shallying methods of Mr. Baldwin".58 official policy was "absolutely beyond [our] comprehension and we are rapidly losing support and subscriptions owing to it", complained the Whitstable Conservative Association.59 The gravity of the position was illustrated by the fact that some Associations went to the unprecedented lengths of passing resolutions openly

56. A. Chamberlain to Mary Carnegie, 9 October 1930, AC $4 / 1 / 1302$.

57. St. Alban's CA, Exec., 30 June and 25 July 1930. This was paralleled by extensive critical debates on policy, a feature unique to this period, in several other constituencies: Uxbridge CA, Council, 11 October 1930; Wells CA, Exec., 11 September 1930.

58. Northern Daily Telegraph, 23 August 1930; Liverpool Post, 24 September 1930.

59. Chairman, Whitstable CA, to Beaverbrook, 15 October 1930, Beaverbrook MSS, B171. 
critical of the leader. 60 others joined the demand for the convening of a Conference of the National Union - a demand tantamount to asserting the right of the localities to make polioy and choose or set aside leaders. 61 The crisis was not confined to the seats of Diehards, or even to the South; whole regions of the Baldwinite North were equally close to rebellion. Derby sounded the alarm after chairing a session of the Lancashire Area in early october, which insisted on calling a special meeting in the near future:

the underlying motive for this meeting is antagonism to Baldwin's leadership. There is to my mind little doubt that there will be a resolution passed which will be ... a vote of censure on Baldwin.

In Birmingham, the Chamberlain citadel, "they are all against the present regime." 63

At the same time, discontent amongst the parliamentary party was at a pitch. The discontent of the right, which had been vocally expressed at meetings of the 1900 Club, was now making the running on the backbenches: "the party is simply rotting before our eyes", wrote

60. Chelmsford CA, Exec., 26 September 1930; Cranford CA, Exec., 10 october 1930, copy in Baldwin MSS, volume 165 , f. 280 .

61. Torquay CA, 7 July 1930; Altrincham CA, Res. in NU Exec., 16 July 1930; North Norfolk CA, Res. in NU Exec., 14 october 1930.

62. Derby to N. Chamberlain, 10 October 1930, Derby MSS, 920 DER ( 17)/33.

63. Hannon to Beaverbrook, 18 September 1930, Beaverbrook MSS, C 154 . 
Orm sby-Gore.64 Page Croft, after talking to many MPs in the Carlton Club, told Neville Chamberlain that "all of every shade of opinion confirm what I told you of the appaling change of feeling. in the country in the last two months." 65 Several of the rising younger men, such as Walter Eliot and Oliver Stanley, were becoming "mutinous". 66 Most serious of all, this mood was matched amongst the members of the former cabinet. Hoare confessed "my fear is that things are moving so fast that unless something happens quickly, everything and everybody will collapse like a pack of cards." 67 Austen Chamberlain was on the verge of "undertaking to bell the cat and gently indicating to $S$. B. that it was time for him to go." 68 To this seething cauldron was added a new initiative by Beaverbrook, who had decided finally on a complete break with Baldwin. ${ }^{69}$ The opportunity to strike was provided by a by-election vacancy in the metropolitan territory favoured by Beaverbrook, at South Paddington, 64. Orm $\mathrm{s}$. MSS S(4) $137 / 44-45$.

65. Croft to N. Chamberlain, 4 october 1930, Croft MSS $1 / 7 / \mathrm{ch} .34$.

66. Ormssby-Gore to Salisbury, 9 October 1930, Salisbury MSS, S(4) 137/55-56; Headlam Diary, 24 September 1930 .

67. Hoare to N. Chamberlain, 8 october 1930, Templewood MSS, VI/ 1 .

68. A. to Ida Chamberlain, 4 October 1930, AC 5/1/516.

69. Beaverbrook to Derby, 19 September 1930, Beaverbrook MSS, C113. 
and he secured Rothermere's support for bringing out, for the first time under the Crusade's banner, an Independent candidate.70 Paradoxically, this attack strengthened Baldwin's crumbling position, for few in the party so desired his departure as to wish to seem to knuckle under to the press lords. Nevertheless, the situation facing Baldwin on his return from France in late september clearly required a major initiative from him if he was to hold his party together - and there were many who feared that it was already too late for even that to preserve his leadership.

Neville Chamberlain, whose position was almost as much at risk as Baldwin's, attempted to stem the tide in Baldwin's absence by revealing his advanced "Unauthorized Programme". In speeches in mid-September he opted for the "emergency tariff", a ten per cent import duty across the board, which he believed would "be heartily welcomed in the party".71 Well placed as Party Chairman to gauge the seriousness of the situation, he devised a plan to announce a major advance in a protectionist direction as soon as possible. Various methods were considered: calling a Party meeting at which Baldwin would unveil the policy was discarded as too risky a proceldure in the present mood of the party; eventually Chamberlain decided 70. Beaverbrook-Rothermere telegrams, 11-18 September 1930 , ibid., C284.

71. Speech at Crystal Palace, The Times, 20 September 1930 ; N. to H. Chamberlain, 1 September 1930 , NC $18 / 1 / 742$. 
to draft an exchange of letters between himself and Baldwin, in which "all talk of Referendum and second General Election [would] be at an end", and the emergency tariff was to be advocated, together with a quota system, rather than a tax, for grain imports. This was to be presented to the meeting of ex-cabinet ministers, the Business Committee, on 7 october for approval.72 Three stumbling blocks remained. Of these the first and least important was the possibility of a refusal on the part of the Free Trade element in the Business Committee, led by Winston Churchill, to accept the new policy. This protest, in the light of the rest of party opinion, could if necessary be ignored. However, two more fundamental structural problems posed an acute dilemma. On the one hand there was a considerable anxiety that with Baldwin still ensconced as leader, casting "a wet blanket" over morale, the new policy would fall flat.73 on the other hand, any move to axe Baldwin and replace him with a more acceptable leader could not be countenanced whilst he was under the press lords' onslaught at South Paddington. Not only would such a move be "hailed as a triumph for themselves by Rothermere and Beaverbrook and would be thought by many people to be so", which would be "in

72. N. Chamberlain diary, 11 October 1930, NC 2/22; N. to I. Chamberlain, 28 September 1930, NC $18 / 1 / 711 ; \mathrm{N}$. Chamberlain to Bridgeman, 8 october 1930, NC $8 / 10 / 13 d$.

73. A. to N. Chamberlain, 9 October 1930, AC 39/2/40; N. Chamberlain to Bridgeman, 5 October 1930, Bridgeman MSS, SRO $3389 / 98$. 
itself sufficiently revolting and it is besides a real danger for the future", but it would also be likely to cause a split in the Party.74 The Business Committee met on 7 October, and considered Neville Chamberlain's drafted letters, but failed to resolve the problem. The mood of the meeting was "profoundly uneasy" and "all of us were racking our brains to find some method of escape from a dangerous situation".75 Eventually, partly as a result of Churchill's objections to the policy, it was decided to adjourn the discussion until 14 october. What was desperately required, as the leadership were stuck with Baldwin and all his defects, was some deus $\underline{\text { ex }}$ machina which could revitalise the political situation.

In the interval between the two meetings a solution to the dilemma was provided, as had been hoped, by events at the Imperial Conference. Of these, the most significant was a declaration on 8 october from R. B. Bennett, the Canadian Prime Minister, suggesting a system of preferential tariffs throughout the Empire if only the Home Government would meet him half way. To this the Labour Government, committed to free trade, had no response to offer; but to Neville Chamberlain, it offered "a truly Heaven-sent opportunity".76 It provided a bridge 74. A. to N. Chamberlain, 9 October 1930, AC 39/2/40; Bridgeman Journal, volume II, p. 225.

75. N. Chamberlain to Bridgeman, 8 october 1930, NC $8 / 10 / 13 d$.

76. N. Chamberlain to Salisbury, 11 october 1930 , Salisbury MSS, S(4) 137/60-62. 
by which party policy could be leapfrogged forward over all objections in a manner best fitting the Conservative Party's imperialist tradition. Furthermore, it avoided any appearance of being a result of, or surrender to, the pressure of the press attacks, and restored Baldwin's prestige by appearing as a great stroke of constructive leadership:

It is an opportunity better than we could have hoped for or dreamed of, to advance our policy. Incidentally, it seems to provide us with a happy issue out of all our Party afflictions.

In the latter sense the response to the Bennett declaration by the party leader was crucial not only for the actual advance in commitment, but also for the very speed and efficiency with which it was announced. This manner restored morale, renewed confidence, and pre-empted completely the counterstrokes of Beaverbrook and his allies. That the chance was seized so promptly was largely the work of Neville Chamberlain, who reacted swiftly after seeing the press reports of Bennett's offer on the morning of 9 october.

I realised we had an unexpected opportunity of coming out with a lead. I spent the whole day in getting a statement drafted, and it was handed to the press in S. B.'s name about six o'clock. In this statement he ... accepted the principle of Imperial Preference and that ... we should formulate our own proposals and submit them to the electors for their definite and final assent.

77. Hilton-Young to Baldwin, 9 October 1930, Kennet MSS $4 / 11$.

78. N. Chamberlain diary, 11 October 1930, NC $2 / 22$. 
The referendum was dead and buried, and this "most anxious week ... has ended in a real scoop for us."79 But this was only to be the first of two stages on the road to rehabilitation. The press release of 9 october contained a definite promise that Baldwin would announce full details of his response the following week, and by this strategem Chamberlain effectively pre-empted the discussions at the Business Committee's meeting of the 14th. On this occasion Chamberlain's prepared draft was rubber stamped, and the effect of this second manifesto was to further restore the prestige of the leadership and the morale of the followers. Also, it gave the latter everything they wanted:

This second statement means, in effect, a free hand to tax anything.... We have now come to this, that [almost] nothing remains between us and the fullest possible policy of protection ... the new statement accepts the Emergency Tariff and makes it part of our policy.

It was "an amazing advance." 80

The reponse was overwhelmingly favourable. The broad centre of the party were reassured, and the prospect of a serious party split or collapse receded even more quickly in mid-October than it had materialised in September. The transformation was especially evident in those associations where dissent had been at boiling

79. N. to Ida Chamberlain, 11 October 111930 , NC $18 / 1 / 712$.

80. N. Chamberlain to Bridgeman, 15 october 1930 , Bridgeman MSS, SRO $3389 / 102$. 
point. In all of these there was a retreat from the brink, and a turnover of majority opinion against the mood of September. 81 outspoken critics on local Executives lapsed into silent acquiescence, or were reduced to an irrelevant minority. The new policy was "clear, definite, and acceptable". 82 Most significant of all was the fact that this sentiment was echoed in a chorus of approval across the length and breadth of the nation, and from all types of constituency. 83 Unity had been restored. The new move provided a bridge to reunite both extremes of the party. Thus the Diehard MP for East Dorset, Hall-Caine, and the free trade member for the Clitheroe constituency in Lancashire, Sir William Brass, could both express agreement with the new policy - which for the latter, at least, indicated a significant advance. 84 This favourable

81. Chelmsford CA, Exec., 17 October 1930; Uxbridge CA, Council, 15 November 1930.

82. Lewes CA, Exec., 27 October 1930.

83. South Kensington CA, Chairman's Agenda, 4 November 1930 ; Harborough CA, Council, 1 November 1930; Northampton CA, Exec.. October 1930; Guildford CA, Council, 20 November 1930; Bath CA, Exec., 11 November 1930; Torquay CA, Exec., 29 October 1930; Lancaster CA, Exec., 18 October 1930; Birmingham CA, Council, 10 October 1930; Gateshead CA, Res. in NU Exec., 14 October 1930; Manchester CA and Spelthorne CA, Res. in NU Exec., 12 November 1930; SUA, Eastern Div. Council, 22 October 1930; on Scottish opinion, see also Gilmour to Baldwin, 12 October 1930, Baldwin MSS, volume 165 , ff. $172-173$.

84. Hall-Caine to East Dorset CA, East Dorset CA, Exec., 27 October 1930; Sir W. Brass, speech at Clitheroe CA, Exec., 16 October 1930. 
response was mirrored in the loyal Conservative press, even in the North, and amongst the parliamentary party at large. The Party Chairman wrote that "all the information that comes to me indicates that the whole party has been bolstered up and feels that it has a policy once more, while sB's personal position has been greatly strengthened." 85 Indeed, for perhaps the first time since the passing by his last government of the Trades Disputes Act of 1927. Baldwin was firmly in tune with the views of his followers, rather than - as had been more often than not the case in the previous three years - lagging behind or contradicting the desires of large sections. 86 In the light of this, the normal centrifugal forces of solidarity and loyalty began to operate, producing a rally round the beleagured leader in the second half of october. In the first instance, the free trade element in the party swallowed the new policy with varying degrees of acquiescence. Derby, and to a slightly lesser extent Salisbury, were willing to accept the new situation. 87 85. N. to Hilda Chamberlain, 18 october 1930 , NC $18 / 1 / 713$.

86. A survery of constituency records indicates that the last occasion to elicit such widespread grassroots approval was the Trades Disputes Act of 1927. Since that local reactions on policy had been at best mixed, at worst highly critical, on issues such as the Flapper Vote, Safety First, and the role of Central office, culminating in the surge of resentment of September 1930.

87. Derby to Beaverbrook, 21 0otober 1930, Derby MSS DER (17)/33; Salisbury to Wolmer, 13 September 1930 , Selborne MSS, Eng. Hist.d. 451, f. 86; Salisbury to Baldwin, 14 October 1930, Baldwin MSS, volume 31, ff. 168-170. 
Winston Churchill, despite the claims of his free food past, which took him almost to the verge of resignation from the Business Committee over the new statements, was prevailed upon successfully to make no public disclaimers.88 In the second place the tariff reformers, having been at perhaps the nearest point they would ever come to throwing in their lot with Beaverbrook in despair, hastened back to support the leader's new move. Croft, announcing "we have achieved our main object", supported the official candidate at South Paddington. 89 Amery declared of Baldwin that "now he has come along on the essential point - though still with a certain fluffiness of language - I think it is only fair that those of us who believe in the policy should back him."90 similar sentiments were felt by Beaverbrook's allies in the Crusade, Elibank and Melchett, and generally speaking the effect was to take the wind out of the crusade's sails. Beaverbrook did not appreciate this, and became more and more unrestrained in his attacks at South Paddington.

The difference between the official policy and the Crusade policy was now very little, but Beaverbrook had

88. Churchill to Baldwin, 14, 16 0ctober 1930, Churchill MSS 2/572, Gilbert, op. cit., volume v, part 2, pp. 191-194; N. to Hilda Chamberlain, 18 October 1930, NC $18 / 1 / 713$.

89. Croft to Beaverbrook, 22 0ctober 1930, Croft MSS 1-4, f. BG 12 .

90. Amery to Beaverbrook, 11 0otober 1930, Beaverbrook MSS, C5. 
lost all faith in the official leadership's ability or will to actually fight for their policy, and thus refused to disband his crusade. Of course, the inevitable result of this, cleverly pointed up in a public exchange of letters between Baldwin and Beaverbrook by the former, was to make it seem as if Beaverbrook was simply satisfying a personal vendetta. This appearance was a twofold advantage for Baldwin. First, the essential justification for Beaverbrook's factionalism had been removed by the leadership's adoption of a popular strong imperial policy, and thus continued hostility from Beaverbrook could be portrayed as a serious threat to the party's chances of putting that policy into operation. In the second place the intransigence of the press lords served to prove Baldwin's thesis at the previous party meeting and to reinforce the theme of hostility to the supposed attempts of press dictatorship.

In this situation the thoughts of the party leadership turned naturally to some method of capitalising on this turn-around of fortunes. Bridgeman thought immediately after the response to Bennett that "we are on better ground for battle than we have been for months. Empire F[ree] T[rade] is discredited ... and so I feel I should like to fight it out at once."91 Rumours of a demand from Gretton and the Diehards for another party

91. Bridgeman to N. Chamberlain, 13 october 1930, NC $8 / 10 / 13$. 
meeting to dicuss the leadership question had been in the air before the Bennett declaration. The leadership took the opportunity to turn this attack on its head, feeling strong enough to concede the demand, in the knowledge that in the changed mood of late october such a gathering would confirm, not destroy, Baldwin's position. Instead of isolating the leadership, the Diehards would isolate themselves. The suggestion of calling a second party meeting was advocated strongly by Bridgeman: "while we are in the ascendant we ought to challenge any opposition in the party", for he was sure that "the policy now produced will be endorsed by a large majority".92 Neville Chamberlain was also in agreement with this strategy: "if Gretton and his friends persist in demanding a meeting to discuss leadership I believe it might be granted without any serious danger just now", he replied.93 Unaware of the extent to which they were thus playing into the leader's hands, the Gretton group made two false moves. A memorial signed by forty-seven MPs in the last week of october provided a pretext for calling a party meeting, again to be held at the Caxton Hall, for the 30 th of that month, a rapid response. The second tactical error made

92. Bridgeman to N. Chamberlain, 16 october 1930 , Bridgeman MSS, SRO 3389/103; Bridgeman to Baldwin, 17 October 1930, Baldwin MSS, volume 165, ff. 33-34.

93. N. Chamberlain to Bridgeman, 18 october 1930, Bridgeman MSS, SRO $3389 / 104$. 
by the Diehards was then to convene a pre-meeting cabal of some forty MPs on 28 october at the St. Stephens Club, where a resolution critical of Baldwin was passed and leaked to the press. Such "U Boat Tactics", seeking to pre-empt the meeting by forcing Baldwin out, produced a further revulsion of feeling in his favour as the honest man under assaut by devious and disreputable enemies. 94

This was carried over to the tone of the meeting itself. Baldwin on his entrance to the Caxton Hall on 30 october was given an immense ovation. He followed the carefully planned strategy by confining his speech to an exposition of the new policy only, avoiding personal issues, and "his manner was strong and his final words impressive".95 Inevitably the motion approving the policy secured unanimous assent. Baldwin then withdrew from the hall, having made his point, and the meeting turned to discuss the leadership question under the chairmanship of Salisbury. The only really effective speech made during this debate was that by Hailsham, which again decisively exploited the vulnerability of the role of the press to secure support for Baldwin:

Hailsham scored a great success, being the only one who pointed out that if Gretton won, not only Baldwin, but every future leader, would have to dance

94. Morning Post, 30 October 1930; Lane-Fox to Irwin, 29 October 1930, India Office Eur. C. 152/19/1/154a; Derby to N. Chamberlain, 31 October 1930, Derby MSS 920 DER (17)/33; Freemantle to Baldwin, 29 October 1930. Baldwin MSS, volume 48, f. 183 .

95. A. to Ida Chamberlain, 2 November 1930, AC 5/1/519. 
to the tune of the Press Plutocrats. This was really the trump card.

The speeches made against Baldwin were of very poor quality, and it was evident that, deprived of a clear justification over policy matters, the irreconcilable element was incapable of making an effective case. Although the result of the final vote, with four hundred and sixty-two votes for Baldwin and one hundred and sixteen against, showed a larger hostile element than had been expected, even this was to some extent discounted due to the personal and political impossibility of most of the minority:

It included of course the so-called Diehards of the Gretton type, who would pursue a reactionary policy that the country would not stand. It included the group habitually described as the Forty Thieves, hangers-on of business, not of the best type, and I suspect a good many old and disgruntled peers.

In fact the meeting proved an even greater success for the leadership's point of view, for the most prominent figures in minority groups openly accepted the verdict of the meeting as final, swinging into line for reasons of party solidarity.

96. Bridgeman to Davidson, 2 November 1930, James, op. cit., pp. 352-353.

97. A. to Ida Chamberlain, 2 November 1930, AC 5/1/519; on the speeches at the meeting see: Headlam diary, 30 October 1930; N. to Hilda Chamberlain, 2 November 1930 , NC $18 / 1 / 715$. 
Baldwin is often described as having been compelled to call both party meetings by the strength and force of the opposition to him.98 In fact, the contrary is the case. When in November 1929 Gretton and the Diehards had previously demanded a meeting, their request was fobbed off. In reality, the party meetings were called by Baldwin to impose his will on the party, and to bring dissent out into the open at a time when it was at a temporarily low ebb.99 The tactic was to force the hard core of irreconcilables to reveal their limited support in the party at large, and to appear as the witting or unwitting dupes of the press lords. They were forced by the order and selection of motions to present themselves in a factious light, by appearing to be separated from the rest of the party on the dubious grounds of the leader's personal characteristics, not the respectable grounds of policy.100 once the meetings are seen as the chosen weapon of the leadership, taking place on their timing, it is not surprising on the one hand that Baldwin triumphed

98. For example, as in the recent work of synthesis by $R$.

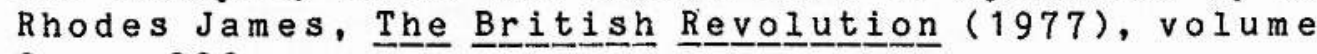
2 , p. 220 .

99. Bridgeman to Baldwin, 22 and 25 June 1930, Baldwin MSS, volume 165, ff. 28-30.

100. Bridgeman to Davidson, 22 October 1930, in James (ed.) Memo으의 of a Conservative, pp. 350-351; N. to Ida Chamberlain, 26 october 1930, NC $18 / 1 / 714$; N. Chamberlain diary, 26 Ootober 1930, NC 2/22; Forster to Baldwin, 29 October 1930, Baldwin MSS, volume 165 , f. 138 . 
at them, and on the other hand such victories had little lasting value. The meetings were an artificial forum, and they failed to have a long-term impact because they were only effective in disguising the extent of anxiety in the party. The voting figures did not show the large element of unsettled but not yet disloyal Conservatives, who felt exposed to the pressure of the Crusade and uneasy about Baldwin's capacity as leader. Many such MPs or candidates, including some of the rising younger men, voted for Baldwin at the party meetings despite serious misgivings. 101 After each party meeting the mood of confidence and consensus proved shortlived, not principaliy because of the activities of Beaverbrook, but because Baldwin failed to sustain the momentum of improvement by being more partisan and forceful in either the Commons or the country. Thus the misgivings dutifully suppressed in the face of the unacceptable press onslaughts cited at the meetings were afterwards confirmed. On both occasions within a few months the situation reverted to being almost as dismal as it had been before. This factor was the reason why even the second Caxton Hall meeting was not the conclusive affair that the leadership had looked for, though it was the more successful of the two meetings in achieving some permanent reduction in the range and quantity of criticism.

101. Lane-Fox to Irwin, 29 October 1930, Halifax MSS, India Office Eur.C. 152/19/1/154a. 
The first Caxton Hall meeting had been a less complete victory, partly because on that occasion the official policy afforded little lasting satisfaction south of the River Trent, and partly because the meeting itself was turned by a much more temporary appeal to the audience's emotions. Baldwin's trick of tarring Beaverbrook with Rothermere's brush, and finessing with the constitutional card, succeeded in the heat of the momentary anger over Rothermere's letter. However, it was not as effective in the long term as his own detestation of the press magnates may have led him tobelieve. Unlike Baldwin, many Conservatives made a distinction between the two men. Rothermere was loathed on grounds of personality and policy by almost all; but many conservatives sympathised with Beaverbrook, and even until the South Paddington election, hoped to work with him. Furthermore, the first meeting was perhaps kept too much under the leadership's thumb, and failed to convince the dissidents that the result was a genuine index of party feeling; thus they refused to accept its verdict as final. 102

In this sense the second Caxton Hall meeting was much more successful from the leadership's point of view. Baldwin was aided by Beaverbrook's unrestrained antics in the South Paddington campaign, which provoked figures such as Hailsham, who was held in particular respect on the

102. N. to Hilda Chamberlain, 21 June 1930, NC 18/1/701; Evening News, 23 June 1930; Daily Mail, 24 June 1930. 
right, to denounce the press lords with unusual vehemence. ${ }^{103}$ The direct effect of the press attacks was to shore up Baldwin's position and make it all the more difficult for figures such as Derby to desert him.104 The crucial achievement of the second Caxton Hall meeting lay in convincing the most influential dissident leaders, such as Croft and Elibank, that they should accept the decision of the meeting as binding upon the minority to accede to the majority verdict. 105 This was secured by an appeal to the spirit of public school fair play, and by allowing the contest to take place to the dissidents' own rules. They were assured a fair opportnity to make their case, and they were to be allowed all the procedural advantages in terms of speaking order, and secret ballot, that could reasonably be claimed. 106 However, the leadership did cover their bets on both occasions by including the prospective candidates in the groups entitled to attend. These people, mainly from the marginal seats of the Midlands, from the industrial areas in the North, and from the Celtic fringe, had a greater vested interest in avoiding electorally extreme positions, and the areas

103. Lockhart diary, 7 October 1930.

104. Derby to Beaverbrook, 21 October 1930, Beaverbrook MSS, C113.

105. Elibank to Beaverbrook, 30 October 1930, ibid., C126.

106. Baldwin to Mrs. Davidson, 2 November 1930, in James, op. cit., p. 354; Halsbury to Salisbury, 30 0ctober 1930, Salisbury MSS S(4) $137 / 94$. 
they hoped to represent were those where both the appeal of Baldwin personally and the instinctive dislike of food taxes were much greater. 107

Baldwin was also on firmer ground on the second occasion in securing acceptance of the policy first, seeming to concede that the question of leadership was a separate matter and not bound up in the policy decision. of course, by divorcing the objection to his policy from that to his person, Baldwin actually made the task of his critics much more difficult. 108 It became impossible because of the choice of timing of the meeting, which was fixed for the day before the poll at South Paddington. This was not because of any analogy with the effects of the Newport by-election on the Carlton Club meeting of 1922, but in order to drive home the point that to remove Baldwin whilst he was actually under the height of press attack would be to lay the party open to the charge of being subservient to the press.109 It was this appeal to their communal self-respect, even more than sympathy with the sympathetic character of Baldwin the man, which produced the marked reaction of hostility to Beaverbrook himself from the floor of the meeting.110 As

107. Headlam diary, 25-29 October 1930 inclusive.

108. Bridgeman journal, volume II, p. 225.

109. Daily Telegraph, 30 October 1930.

110. Beaverbrook to Mildmay, 31 October 1930, Beaverbrook MSS, B 167 . 
the decision of the second Caxton Hall meeting was a foregone conclusion under these circumstances, the manoeuvre of calling it involved few risks and offered significant gains. Beaverbrook himself had no doubts before the meeting that Baldwin would get his vote of confidence. 111 Baldwin's procedural concessions at the second party meeting did not reflect any weakness in his position; on the contrary, they reflected its strength and his confidence in the aftermath of the favounable reaction to his having finally grasped the 'free hand'.

The verdict of the party meetings also settled another issue in dispute - the very distribution of power in the party. On several occasions during the party crisis between the defeat in the 1929 election and the second Caxton Hall gathering the dissatisfaction at the grassroots with party policy past, present and future, had lead inevitably to demands for a voice in the policy formulation process. These were moving from the implicit to the dangerously explicit, and if unsatisfied might have lead either to serious revolt along the lines of 1922, or open demands for executive power to rest in the National Union and not the parliamentary front benches, or even both. The decisiveness of the response to the Bennett offer in October 1930 defused this danger at one and the same time as it satisfied the rank and file on fiscal policy. There is no doubt that the leaders conceded a

111. Beaverbrook to James, 26 October 1930, ibid., B158. 
great deal to retain control, but at the end of the day their position was preserved. Neville Chamberlain was relieved that the october party meeting

showed no disposition to question the view that decisions on policy are made by the Leader, after taking such advice as he chooses; and that they require no endorsement from any body representing the Party in any way before becoming binding on the Members.

Autocratic oligarchic control remained, and was deferentially responded to, a factor of considerable importance in the very different problems faced by Baldwin in 1931 - first in defeating the final assaut on his position in the spring, second in forming the National Government in the autumn.

The events of September and October 1930 also underlined the rise of Neville Chamberlain himself. The period of opposition during the second Labour Government was a vital phase of his career, for it transformed him from being merely one of several promising cabinet ministers to the position of crown prince and heir apparent to Baldwin and thus, eventually, to the Premiership. Chamberlain had been one of the successes of the 1924-1929 Government, but in a minor department on a 112. N. Chamberlain to Bridgeman, 1 November 1930, NC $8 / 10 / 16 \mathrm{c}$. 
politically dull programme of measures. This spell at the Ministry of Health had demonstrated talent as an administrator and drafter of legislation, but it was by no means clear that he had demonstrated leadership qualities as a politician. He was "more at home in the frozen regions of politics", and thought by Bridgeman to be "too bureaucratic". 113 Indeed, his political wisdom was open to doubt after having been, together with Churchill, responsible for the unpopular derating measures. Neither this, nor other expensive or remedial social legislation were particularly popular with the rank and file in the light of the 1929 election results. Aware of the limitations of the Ministry of Health, Chamberlain had sought transference to the Colonial Secretaryship, where his assumption of his father's mantle might mend his bridges with the grassroots. The election defeat removed this opportunity from his grasp. Political reputations are far more variable than history often depicts, and in the closed circles of Westminster the index of political standing fluctuates as frequently as the prices on the Stock Exchange. In May 1929 Chamberlain was in a down phase, and he sought for the remainder of the year opportunities to restore his influence. He remained unclear as to which course to follow, adopting a low profile throughout the summer of 1929, and following this with a lengthy winter absence in East Africa.

113. Hannon to Beaverbrook, 15 August 1930, Beaverbrook MSS C154; Bridgeman journal, volume II, p. 207. 
On his return he resolved to use the Chairmanship of the newly created Conservative Research Department, which he had been given control of, to direct and influence party policy.114 However, such a back-room position remained essentially unsatisfactory. It could only be a first small stage in rehabilitation. The usefulness of the Department was nonetheless a revelation to Chamberlain, and led his thoughts to the possibility of combining with it the Party Chairmanship. Baldwin was manoeuvred by Chamberlain, who exploited the growing hostility to Davidson, and by using his own initiative in pushing the latter out, created a position in which his own control of Central office, either through an intermediary or directly, would be assured. In May 1930 Chamberlain's position in the party hierarchy was still open to question, and he desired the Chairmanship as a means of asserting his centrality to all party issues. In this sense his vision of the Central office as the directing force of the party, as literally the Central Organ, rather than an administrative workhouse such as the Researoh Department, explains his desire for the position; Chamberlain was always happier in a defined institutional role in which he possessed executive power. His position at the Reasearch Department had been dependent upon Central office without clear powers over it; but now Chamberlain could emerge from those shadows.

114. N. to Ida Chamberlain, 22 March 1930, NC 18/1/686. 
The appointment to the Party Chairmanship in June 1930 marked the beginning of Neville Chamberlain's rise. This fell into three phases between June 1930 and August 1931, by which point his pre-eminence was completely assured. The Chairmanship filled a crucial role in the first two of these phases. It was a position of unique importance in the party during periods of opposition. Indeed, below the leader himself there was no other exofficio position which secured a voice in every significant decision; certainly membership of either the ex-cabinet or of the Business Committee did not ensure such influence. ${ }^{115}$ It was this position which Chamberlain exploited during the first phase of his rise, from June to October 1930. In this period Chamberlain slowly built his reputation, endeavouring to conciliate Beaverbrook and secure the dropping of the referendum for the free hand. His new-found political maturity emerged in the initiatives he took in September and october 1930, first in the 'Unauthorised Programme' speeches, and second in his masterminding of the response to the Bennett declaration. Chamberlain avoided many of the pitfalls of his office by simply not doing the same job as Davidson had done. The latter had been a long-term working organiser; before his appointment Chamberlain was careful to have it made public this his own tenure was to be temporary for the current emergency. This he did for two 115. Bridgeman to Salisbury, 5 November 1930, Salisbury MSS, S(4) 138/14-15. 
reasons. First, to emphasise his role as a new broom with a mandate to reform the Central office from above, not cut from the normal pattern of Chairmen, but limiting himself to grand policy rather than the grind of detail. Second, it was intended to assert that his Chairmanship did not rule him out from relinquishing it for cabinet of ice should the Labour government be replaced by a Conservative administration in the near future. Essentially, Davidson had been a glorified clerk for Baldwin, attending to the minutiae of organisational details and fund-raising. Chamberlain's reforms of Central office reflected his style of Chairmanship. They were designed to liberate the Chairman from such work so that he might take on a more overt political role. Chamberlain also saw the role of Chairman vis-a-vis the leader in a different light. Davidson had seemed too much still the personal secretary. Chamberlain intended to be chief counsellor and to use his institutional access to the leader to shape his outlook in the direction Chamberlain wished the party to move. In short, he intended to be an active, interventionist, power in his own right - as no chairman previously had been. Thus he maintained a high profile, distancinginimself from details except where, as in the case of the crucial byelection contests or the control of the party publicity machine, such powers brought solid advantages. The coup which marked the successful end of this first phase of Neville Chamberlain's emergence, the swift response to 
Bennett's offer and the restoration of the leadership's position in October 1930 provided the pay off he had been hoping for when he had invested his political capital in the Chairmanship. He told his sister that "as we thought the Chairmanship of the Party does enable one to direct the policy though nominally he has nothing to do with it". 116

During the second phase of Neville Chamberlain's rise to the position of heir apparent, which comprised the remaining period he spent as Party Chairman between November 1930 and April 1931, his position was still vulnerable to the changing tides of fortune. The position of Chairman inevitably attracted blame and involved conflicts and disputes with some members of the Party. 117 Furthermore, Chamberlain was still in danger of being too closely identified with Baldwin, and of being dragged down with him should his position once again collapse. Most important of all, Neville Chamberlain, although since his achievements of 1930 now increasingly spoken of as a candidate for the succession, was still only one figure among several possible contenders. The significance of the second phase of Chamberlain's rise was the gradual manner in which he positioned himself to outpace these

116. N. to Hilda Chamberlain, 18 october 1930, NC $18 / 1 / 713$; N. Chamberlain to Bridgeman, 15 Ootober 1930, NC $8 / 10 / 15$.

117. A. to Ida Chamberlain, 16 November 1930, AC 5/1/520. 
rivals in the period up to April 1931. The third and most crucial phase of all was his capitalisation on his successes in the period after stepping down from the Chairmanship, between April and August 1931, during which he consolidated his position as the single and uncontested heir apparent to Baldwin. He was, perhaps, the only figure in the party actually to gain prestige and credit from the tangled and unhappy events of the 1929-1931 party crisis. 


\section{CHAPTER 5}

Beaverbrook Beyond the Pale: November 1930 to $\underline{\operatorname{March}} \underline{1931}$

The verdict of the second Caxton Hall meeting isolated Beaverbrook from his Conservative allies, and placed him beyond the pale of respectable Conservative politics. Baldwin's policy concession of October 1930 had proved sufficient to detach from Beaverbrook all his significant Conservative sympatisers and fellowtravellers, leaving him only the alliance with Rothermere. Amery was the first to respond, but Baldwin's clarification of his policy in the week after the Bennett declaration also met the requirements of both Elibank and Melchett. ${ }^{1}$ The latter wrote that "it seems to me that we have won a realiy great victory as Baldwin has accepted practically the whole programme", and suggested calling of the Crusade challenger at South Paddington. 2 Elibank was quite clear that any minor differences should now be discussed within the Conservative umbrella; it was the policy, not the leadership, that was the issue at stake:

I am for going for the policy and nailing that to the mast and letting the question of leadership look after itself. The more [Beaverbrook and Rothermere] attack S. B. the more firmly he is being established in the saddle.

Furthermore, to continue warfare in the new mood of party

1. Amery to Beaverbrook, 11 October 1930, Beaverbrook MSS C5; Elibank to Beaverbrook, 22 october 1930, ibid., C 126 .

2. Melchett to Beaverbrook, 22 october 1930, ibid., C243. 
unity would only raise "all the worst passions and feelings of enmity even amongst people who have hitherto supported [Beaverbrook]."3 Distancing themselves publicly from Beaverbrook, Melchett and Elibank issued a press statement accepting the new policy. Croft also joined the chorus of appeals from the protectionist right wing to Beaverbrook requesting his moderation, and urging him to work now within the party for the success of its new policy. ${ }^{4}$ Even Hannon wavered, suggesting in a long memorandum on the political position prepared for Beaverbrook, that the Crusade adopt the Baldwin policy but retain its separate political machine with which to campaign for it. 5 In the context of this uncertainty, the decision of the meeting held at the Caxton Hall provided a way out of the dilemma. The Conservative dissidents responded to the party traditions of loyalty, and accepted publicly the verdict of the meeting. The divisions amongst the protectionists were made absolute by Beaverbrook's decision not to be bound by the result of the Caxton Hall vote, despite attending the meeting. The only result of this was to add further credence to Baldwin's denunciation of Beaverbrook's political impossibility. The links between Beaverbrook and his

3. Elibank to Garvin, 26 October 1930, Elibank MSS, SRo, GD 32/25/69, ff. 96-97.

4. Croft to Beaverbrook, 5 November 1930, Croft MSS, CRFT $1-4 / B G 14$.

5. Memo by Hannon, 3 November 1930, Beaverbrook MSS c154. 
allies, Elibank, Amery, Croft and Melchett, were severed after Ootober 1930. This is a marked feature in the voluminously comprehensive Beaverbrook papers; correspondence with his Conservative allies does not just fade away, it ceases abruptly in November 1930. Personal contacts also dwindled, with Amery breaking silence at Christmas to write, "I have not seen you for the best part of three months". 6 In tactical terms, Beaverbrook was from now on beyond the pale, paying the price of rejecting the irksome, moderating advice of the Conservative fellowtravellers in favour of the intransigent admonitions of Rothermere.

Placed against this serious deterioration in Beaverbrook's power base, not only amongst the leaders of Conservative imperial sentiment, but also in the constituencies which were in the process of rallying around the official position in late october 19307, the victory of his candidate over the official nominee at the South Paddington on 31 october by-election was hardly a consolation. Contemporary political opinion was quite clear that the by-election result did not signify compared to the Caxton Hall meeting of the previous day; "the result can do very little harm to the Conservative Party",

6. Amery to Beaverbrook, 22 December 1930, ibid., C5; see also files C126, C243, C101, and C 307 .

7. Birmingham Post, 1 November 1930.

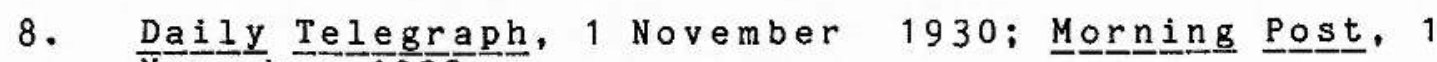
November 1930 . 


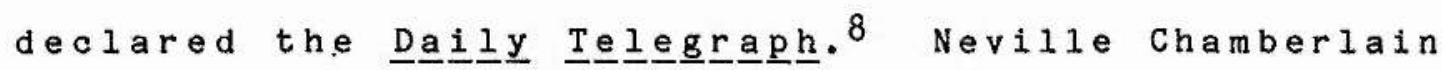
attached little importance to it, putting it down mainly to the poor quality of the official candidate. 9 In fact, the South Paddington election did not herald some new phase in the struggle, but was rather the last manifestation of the unrest visible throughout the party in September 1930. This was, by the time when the south Paddington result was announced on 31 october, largely a thing of the past.

Indeed, Baldwin's position in November and December 1930 was probably stronger and more firmly based than it had been at any time since the 1929 general election. In the constituencies "the general feeling was that the risk of division in the Conservative ranks was appreciably less", and approval continued to be manifested across the board for Baldwin's position. 10 This was echoed by opinion in the lobby of the House of Commons, the backbenchers' 1922 Committee recording in late November "the general impression that ... the party was rallying towards unity." 11 The extent of this new mood was visibly

9. N. to Hilda Chamberlain, 2 November 1930; to Ida Chamberlain, 8 November 1930, NC 18/1/715-716.

10. Cirencester and Tewkesbury CA, Finance and Advisory Ctte., 10 November 1930; Lincoln CA, Exec., 21 November 1930; Somerset Prov. Div., Council, 3 November 1930; Metropolitan Area Res., NU Exec., 12 November 1930; Lancashire and Cheshire Area Res., Northern Counties Area Rea., Greenwioh CA Res., Uxbridge CA Res., in NU Exec., 9 December 1930.

11. 1922 Committee Minutes, 24 November 1930, in P. Goodhart and U. Branston, op. cit., pp. 40-41; Bayford diary, 22 March 1931. 
underlined by two representative gatherings of the party rank and file: the meeting of the Central Council of the National Union on 25 November, and the Annual Conference of the Scottish Unionist Association on 12 December. The tenor of both these meetings indicated the extent to which the tide of party opinion was now flowing in Baldwin's directon. 12 Beaverbrook's power base had been seriously diminished, but his campaign had not yet been completely destroyed.

Beaverbrook's response to the atmosphere of November and December 1930 was to markedly slacken his activities, and to return once again to the path of negotiations. On this occasion the intermediary was the City financier sir Abe Bailey, who approached Neville Chamberlain on 4 November at Beaverbrook's suggestion, and arranged a meeting. Chamberlain was still resentful and distrustful over the break up of the last bout of negotiations due to the Bromley by-election, and, with the situation on this occasion so strongly in his favour, had little need to unbend, feeling no particular urgency in clinching terms. once again, the problem of the Rothermere connection proved the stumbling block to any immediate deal. Beaverbrook again raised the topic of a seat for Esmond Harmsworth as the bait to bring in the latter's father, Rothermere. This Chamberlain could not and would not consider as a preliminary to a settlement, although he 12. Bridgeman, Political Journal, December 1930, volume II, p. 227 . 
did not rule out a seat for Esmond as the eventual product of peace. "Anything which looked like a surrender to [the press lords] in the present state of feeling would be howled out of court", declared Chamberlain. The press barons must make the first moves, "by lowering the temperature in their papers". Thus the lessening of hostilities would itself lead to an arrangement, rather than the other way around. Although it proved impossible to come formally to such a settlement so soon after the bitter atmosphere of South Paddington, the informal arrangement for neutrality operated successfully during November and December 1930. In further negotiations at the beginning of December, Beaverbrook and Chamberlain explored the possibility of drafting some agreed exchange of letters, but at that stage it proved impossible to find a formula satisfactory to both and humiliating to neither; accordingly, the decision was taken on Beaverbrook's suggestion just to "let matters drift". 13 This was acceptable to Chamberlain, for throughout this period the level of criticism in the Beaverbrook press had indeed been reduced; thus he had already gained almost all he could look for from a formal agreement.

Ironically, the cause of the breakdown of this promising trend was once again to be the constituency of South Paddington. The local troubles here between the Crusader MP, Taylor, and the official local Conservative 13. N. Chamberlain diary, 6 November 1930, 5 December 1930 , NC $2 / 22$. 
Association gradually embroiled the principals on both sides, Beaverbrook and Neville Chamberlain, in another confrontation. The crunch came when the local Conservatives insisted in mid-December in selecting a new official candidate, H. G. Williams, to contest the seat against Taylor at the next election. In his position as Party Chairman Neville Chamberlain had no option but to support the right of the local association to do so, hoping nonetheless that this would not destroy the entente. 14 However, by Christmas 1930 the mood created by the second Caxton Hall meeting was dissipating. Beaverbrook, sensing renewed opportunities, and restless in his inactivity, seized on the affair of the Williams candidature to revert once again to an openly hostile path. 15 But South Paddington was merely the final straw in the series of factors which had been undermining Beaverbrook's inclination to compromise.

The most important of these remained his doubts over policy, which were two-pronged. of these the first concerned his continued suspicion of Baldwin's reliability as being "by virtue of his titular position as head of the Conservative Party" potentially still the greatest danger. The logical result of this suspicion, seemingly confirmed by Baldwin's failure to put his policy across forcefully

14. Ibid., 1 February 1931.

15. Lockhart diary, 15 December 1930. 
in December, was the conclusion that "in order to achieve Empire Free Trade, we have got to defeat Baldwin". ${ }^{16}$ The second area of policy difference concerned the thorny topic of agricultural protection. ${ }^{17}$ From the very beginnings of the Crusade at Lewes in 1929 it had been pitched to the farmers, and this trend increased in the winter of 1930-1931, when they remained the only section of Conservative sentiment not completely appeased by the advances in party policy. Beaverbrook's growing identification with the farmers evolved throughout 1931, and was eventually to lead him to disband the Crusade and to form and back an open and avowed Agricultural Party. This was still in the future, but in January 1931 he opened his campaign again with a manifesto to farmers which offered a simple policy of protection for the home producer. ${ }^{18}$ In this policy, and in his general mood of intransigent hostility adopted in January 1931 Beaverbrook was encouraged and supported by his only remaining ally, Rothermere, who was urging all-out assault on Baldwin. ${ }^{19}$ Thus, by mid-January 1931, the prospect of a truce, instead of drifting closer, had been washed away out of

16. Beaverbrook to Horne, 23 January 1931, Beaverbrook MSS, C 178 .

17. Beaverbrook to Melchett, 11 November 1930, ibid., C243.

18. Beaverbrook to Fitzalan, 24 March 1931, ibid., C134; Beaverbrook to Lush, 24 January 1931, ibid., B200; Beaverbrook to Gray, 19 March 1931, ibid., B197.

19. Rothermere to Beaverbrook, 14 January 1931, ibid., C285. 
sight by changes in the political currents. The press lords were once again on the lookout for a suitable constituency, preferably metropolitan, in which to declare war on Baldwinism. 20 This threat from without would, however, have been of little significance, considering the vastly stronger and more secure position of the party leadership compared to that during the previous such assaults in september 1930, had not the confidence manifested so noticeably throughout the party in November since been significantly diminished. This erosion of confidence in Baldwin was a far more serious danger than that provided by Beaverbrook, who was not merely isolated from his party allies, but beyond the pale as a consequence first of his political methods, and second of his alliance with the detested Rothermere.

The decline in Baldwin's position was a matter of internal Conservative politics and had little to do with the spectacular but largely irrelevant fulminations of Beaverbrook, whose campaign, despite its agricultural protectionism, seemed almost entirely to be the product of personal animosity. The dangers to Baldwin's position in the winter and spring months of 1931 were very largely of his own making, and they provoked a crisis of confidence within the party leadership over his suitability as leader that had almost nothing to do with the crusaders' activities. Indeed, at the height of the internal crisis of confidence in February and March 1931 it was the 20. Beaverbrook to Amery, 14 January 1931, ibid., C5. 
distractions caused by the press lords' interventions in two London by-elections which, ironically, enabled Baldwin to buy sufficient time to yet again restore his crumbling position.

The universal satisfaction of Conservatives with the position attained in November 1930 was undermined in the first instance by failures on Baldwin's part in two areas. of these, the first was in explaining and advocating the fiscal policy of the party, and the second his weakness as leader of the opposition in the House of Commons. These were, of course, exactly the same problems that had undermined each previous re-imposition of control, in November 1929 and in March and June 1930. On the previous occasions the dissatisfaction of many of his followers with the official policy had been a third factor, which at least now no longer applied. But the continued existence of the other two problems was sufficient to cause the newly gained morale of the parliamentary party to dwindle away. Baldwin was no longer so vulnerable to the attacks of the crusaders, having squared his policy, but his continued failure to provide an acceptable style of leadership in parliament was by the spring of 1931 making him increasingly appear to his immediate frontbench colleagues as a dangerous liability. It was this anxiety, rather than any plots or intrigues, which produced the incipient leadership crisis of February and March 1931. For this reason Baldwin's cautious line in expounding his policy to the country was perhaps the less serious of the 
two factors undermining his authority. However, it was a weakness which provoked renewed doubts amongst the barely reconciled right wing, national and local, and which played into Beaverbrook's hands. Amery noted at Christmas, 1930 that "the real thing that worries me now is not the official policy, but whether we are getting up enough steam in the electorate". 21 The principal criticisms of Baldwin were first, his cautious approach, for having refused to rule out food taxes he still did not want to advocate them, at least in the north; "he apologises for them, and attaches a great many 'ifs' to any statement he makes regarding such duties".22 The second problem was Baldwin's relapse once again to a mood of lethargy and inactivity, which Dawson described as "a sort of comfortable winter quarters", hardly the hallmark of vigorous and inspiring leadership. 23

This disappointment of the expectations raised at the second Caxton Hall meeting was carried over into the parliamentary party, where there was by Christmas "nothing but grouse[ing] all the time". 24 In particular, two debacles of parliamentary mismanagement in November and December, 1930 underlined the general dissatisfaction.

21. Amery to Beaverbrook, 24 December 1930, ibid., C5.

22. Beaverbrook to Frusher, 22 December 1930, ibid. B149.

23. Dawson to Willingdon, 16 December 1930, Dawson MSS.

24. N. to Ida Chamberlain, 23 December 1930, NC 18/1/721. 
The first of these was a thoroughly unsuccessful speech by Baldwin in a vote of censure debate on 27 November against the Government's refusal to consider Bennett's imperial preference proposals - all the more serious for the fact that Baldwin's dismal showing was in the very area of politics in which he most needed to look like a new man. The vote of censure debate was a rushed and bungled job, in which Baldwin tripped over his own feet in his efforts to restore his position, and instead of raising his stock in the eyes of colleagues and MPs, the result was a serious slump in confidence.25 It was "one of his most futile speeches... he sawed at his tough material with a blunt knife... this speech was flabby and pointless throughout". 26 The consequence of the decline in morale of Conservative MPs was a similar phenonmenon of absenteeism and apathy on their part - a reflection of their leader's own conduct - similar to that noticed in December 1929 and January 1930. It was this feature which led to the second humiliating debacle, when on 10 December a Conservative motion criticising the Government on overspending and failures in economy was counted out in the House due to lack of support; a serious fallure of organisation on the part of the whips and the front bench. As the issue of economy was coming to be placed before

25. Lane-Fox to Irwin, 3 December 1930, Halifax MSS, India Office, Eur.C 152/19/1/180.

26. A. to Ida Chamberlain, 30 November 1930, AC 5/1/522. 
all else by the party at large, this fiasco produced howls of outrage and anger in the National Union. 27 At the same time, Baldwin's personal aloofness from many of the younger backbenchers was becoming a serious bone of contention among the parliamentary party. The result was that by January 1931 even staunchly loyal Baldwinite MPs were becoming worried over the general slump in the leader's personal position. There was "a great deal of criticism of the leader by solid men because a stronger and more fighting lead is not being given to our party", wrote Smithers, whilst Lane-Fox privately warned Irwin that "many think that $S B$ is weak and woolly, and is letting the party down". 28 This loss of confidence in Baldwin as leader was echoed to a greater degree than ever before amongst the inner circle of party leaders. Cunliffe-Lister described the position as "impossible"29 and Austen Chamberlain declared in February 1931 that "S. B. is not a leader and nothing will ever make him one.... I think that a crisis is rapidly approaching and that it would be a mistake to do anything to defer it." 30 The seriousness of the position was echoed by such loyal figures as Linlithgow, Amery, Hoare, and Neville 27. NU Exec., 13 January 1931; South Kensington CA, Exec., 13 December 1930.

28. Smithers to Fry, 1 January 1931, Baldwin MSS, volume 166, ff. 275-278; Lane-Fox to Irwin, 28 January 1931, Halifax MSS, India Office, Eur.C 152/19/1/221.

29. Bayford diary, 22 March 1931.

30. A. to Ida Chamberlain, 28 February 1931, AC 5/1/532. 
Chamberlain, and reached an acute stage in the second half of February. 31 Baldwin's colleagues did not wish to see him go, but were being inexorably forced towards viewing that as the least damaging solution to the party's difficulties. However, none of them was a clear candidate for the succession, none of them desired the leadership at a time when it was such a crown of thorns, and none wished to take the initiative in suggesting to Baldwin that he should, in the interests of the party, stand down. 32

There were four possible contenders for the lead, should Baldwin retire: Churchill, Horne, Hailsham and Neville Chamberlain. Of these, Churchill had ruled himself out by resigning on 27 January from the shadow cabinet over India, and by the fact that he had almost no personal following among Conservative MPs. Though on India he echoed the views of the Diehard right, he was not a favoured candidate with any section of the party, not least for his known free-trade inclinations. Sir Robert Horne was a far more serious contender, popular and acceptable to the tariff reformers and the business element on the back benches. However, he was not keen to return to a fully active political ife, and furthermore had increasingly supported Baldwin since June 1930 as the best available leader, breaking with Beaverbrook in the

31. Amery diary, 24 February, 6 March 1931, in My Political Life, volume III $(1955)$, pp. 38-39; N. to Ida Chamberlain, 21 February 1931, NC $18 / 1 / 727$.

32. Dawson to Irwin, 5 March 1931, Dawson MSS. 
process. Horne's attitude remained in January 1931 one of loyalty to Baldwin, illustrated by his publicly moving a motion of confidence and support at the Glasgow Unionist Association annual meeting. 33 Horne might have accepted the leadership if thrust upon him, but there is no indication that he sought preferment. The most likely candidate in the event of a vacancy was Hailsham, whose credentials with the right of the party were strong, but who had also the trust of the moderates after his defence of Baldwin at the second Caxton Hall meeting, and who was, moreover, currently acting leader in the House of Lords during Salisbury's illness. Hailsham was also a reluctant candidate: "I have never coveted leadership. I shouldn't be in the Lords now if I had", he wrote in February 1931.34 Indeed, Hailsham had also taken Baldwin's side strongly in the recent stages of the struggle with Beaverbrook, despite the fact that he thought that to so identify himself with Baldwin damaged whatever prospects he may have had: Nonetheless, Neville Chamberlain accurately surmised that "if therefore SB does disappear there is a strongish possibility that the two Houses would unite in choosing Hailsham as leader." 35

33. Glasgow CA, AGM, 26 January 1931.

34. Hailsham to Elibank, 21 February 1931, Elibank MSS, SRO GD $32 / 25 / 76$, ff. $12-14$.

35. N. to Hilda Chamberlain, 1 March 1931, NC $18 / 1 / 728$. 
Neville Chamberlain was also a possible contender for the position. However, both he and Hailsham were principally motivated by a concern for party unity, a unity endangered by Baldwin, not by them. Without such party unity, the overriding aims of getting the Labour government out - all the more urgent as the economic position declined - and winning the next election were unlikely to be attained. Yet on the other hand, both appreciated that the divisions caused by the aftermath of Baldwin's resignation could be as damaging as those already existing. This concern resulted in the first instance in the two men reaching a tacit agreement to stand together, each offering to serve under the other if chosen by the party. This concession in fact revealed that neither was principally motivated by coveting the leadership; they were much more concerned to prevent either a party split or the victory of some maverick figure should Baldwin retire. There is no doubt that the combination of Hailsham and Chamberlain was widely favoured in the party, for the very reason that it was believed it would bring peace and security, with the minimum of fundamental change. 36 The concordat of Neville Chamberlain and Hailsham, reached in the last week of February 1931 was not the prelude to a plot to force out Baldwin, but was the sensible precaution of pragmatic politicians preparing their contingency plans for possible

36. Ibid.; Bayford diary, 22 March 1931. 
eventualities. It was a reflection of the crisis of confidence in Baldwin's leadership in the spring of 1931 , and not a contributory cause. However, there remained grave doubts over the pros and cons of Baldwin's withdrawal. For all his defects, he still seemed to be the figure who divided the party least of all the potential leaders - none of whom had the complete confidence of the party either. Churchill was strongly suspected of instability, intrigue, and for his association with Lloyd George. Horne also was tarred with the brush of coalitionism, and was in any case in semiretirement. Hailsham was thought to be too impetuous, and although his position in the House of Lords did not rule him out, his lack of contact with many MPs was a considerable practical barrier. For Neville Chamberlain, occupancy of Central office had proved a mixed blessing, for whilst it had enhanced his prominence considerably, he had also in the process inevitably made enemies. In addition, his unapproachability was a serious problem; Headlam, describing him as "a cold fishy creature who puts your back up in five minutes", was far from alone in his view. 37 Thus to change horses in mid-stream seemed to offer little advantage, especially as none of the jockeys was keen on the attempt. A further reason for avoiding change was the very torrent of the metaphorical stream; in the face of the renewed attack on Baldwin by the press 37. Headlam diary, 3 December 1930, 10 March 1931; Dawson to Irwin, 28 September 1930, Dawson MSS. 
lords in by-elections in February and March, there was both a rally of sympathy to him and the perennial problem of not appearing to bow the knee to press dictation. Furthermore, no real differences of policy or approach divided Baldwin from his colleagues, for they did not disagree with his political strategy, but merely despaired of his personal ability to carry it through. The crisis of spring 1931 was a matter of manner and style, of confidence and not of substance. The situation in February 1931 was one of extreme uncertainty. "I have never known such confusion in party politics" admitted Robert Cecil. 38 The party leaders were caught on the horns of a dilemma, and whilst increasingly looking upon Baldwin's retirement as the lesser evil of the alternatives available, were so little attracted by the prospect that they continually shrank from taking any practical action. 39

It was in this atmosphere that the party's Principal Agent, Topping, informed Chamberlain, as party Chairman, that the situation was becoming so serious that he felt bound to set down the facts in a memorandum for his formal attention. This document set out from the premise that

since the [second] Caxton Hall meeting there has not been so much support for Beaverbrook, but there has been a very definite feeling that the leader is not strong enough to carry the party to victory.

38. Cecil to Irwin, 9 March 1931, Halifax MSS, India office, Eur.C $152 / 19 / 1 / 262$.

39. A. to Ida Chamberlain, 7 March 1931, AC 5/1/533. 
The tone of most of the memorandum was studiously vague, and its principal concern was not so much that Baldwin should go, but the fear that if he did so the resulting confusion might result in the choice of Churchill because of his Diehard line on India. Topping's conolusion, however, was definite enough: Baldwin

does not hold a strong position in the party at the present moment. There has, of course, been dissatisfaction with the leadership ever since the Beaverbrook and Rothermere campaign started, but for a long time it was confined to a comparatively small section. Today, however, the feeling that he is not a strong leader is widely felt and cannot, in my opinion, be ignored.

40

Such an expression of opinion from the party's principal official forced a decision on Chamberlain - as there can be little doubt that Topping intended it to do. Chamberiain grasped at the memorandum as the solution to his conflict of loyalty versus his loss of confidence in his leader, writing to his sister that "Topping has been the deus ex machina". 41 The Topping memorandum was not the spearhead of a plot, except in the possible sense that Topping may have deliberately painted an over-dismal picture, but was rather the final straw, convincing most of Baldwin's colleagues that he would have to withdraw from an untenable position. Far from rushing to exploit 40. Memo, Topping to Chamberlain, 25 February 1931, quoted in full in I. Macleod, Neviㅣ늘 hㅡamber $(1961)$, pp. 139-141.

41. N. to Ida Chamberlain, 1 March 1931, NC $18 / 1 / 728$. 
this opportunity, Chamberlain continued to hesitate over the best course to take, and, making no secret of the memorandum, consulted a wide range of his colleagues, all of whom agreed that the memorandum should be shown to Baldwin. Such discussion was far from intrigue, for Chamberlain consulted not only his brother Austen, Hoare, Cunliffe-Lister, and Hailsham, but also the chief whip Eyres-Monse11, and Bridgeman, the latter being perhaps Baldwin's most trusted and loyal associate. Hailsham, moreover, wanted Baldwin to be given a further opportunity to redeem himself in his forthcoming speech at Newton Abbot, and suggested holding the document back for ten days.

Neville Chamberlain was unhappy over this, fearing the greater damage that might result from delay, but agreed at first for fear that his haste might be misinterpreted as the cloak for ambition. over the weekend of 28 February-1 March he wavered between forwarding the memorandum or holding it back, finally deciding on Sunday, 1 March, to send it to Baldwin at once. The final incident, in many ways the least significant of them all, which removed his doubts over making Baldwin aware of the situation was renewed evidence of the collapsing morale of the parliamentary backbenchers and ex-junior ministers. With the sudden death of Worthington-Evans in mid-February a by-election was to be held in March in his constituency of Westminster St. 
George's, one of the safest Conservative seats in the country. Moore-Brabazon, a former junior minister, had seemed most likely to be selected by the local Conservative Association to fill the vacancy, but when an independent Conservative challenger, Sir Ernest Petter, came forward with the backing of the press lords and announced he would fight the official nominee purely on the leadership issue from an anti-Baldwin platform, MooreBrabazon announced in the evening papers of 28 February that he withdrew as he was unwilling to support Baldwin; the local association found itself embarrassingly unable to find a candidate willing to champion the official party leader. Faced with the fact that the crisis of confidence, not in fact of the constituencies, but of parliamentarians of the Moore-Brabazon type, was now clearly both acute and public, Neville Chamberlain realised that he could withhold Topping's memorandum no longer. On the morning of Sunday, 1 March, he had it delivered to Baldwin's London residence by messenger, together with a covering letter. After relating his actions and hesitations over the memorandum since Topping had handed it to him, he enclosed it without further comment other than an apology for adding in any way to Baldwin's anxieties at a difficult moment, but "the situation is evidently one of extreme difficulty and will need most careful handling". There was no suggestion that Baldwin should retire - indeed, a passage that might have given that impression was deliberately struck out of the 
draft - only the comment that Baldwin would no doubt wish "to consult several of your friends". 42

In fact the Topping memorandum was sent to Baldwin not necessarily to force his retirement, though that was thought a probable response, but rather in the hope that, one way or another, he would respond to the gravity of the position and thus resolve a confused and unhappy predicament for all concerned. Thus, once the memorandum was delivered, the decision was left entirely to Baldwin, without any attempts to pressurise him towards resignation. In fact, a close examination of the events of late February and early March 1931 provides no real evidence for any consiracy theory of a plot to oust Baldwin, and loyalty played a greater part than ambition in the actions of Baldwin's colleagues. At the end of March Baldwin's trusted friend Bridgeman assured him that Neville Chamberlain "has I am sure been thoroughly loyal to you in a very difficult position". ${ }^{4} 3$ Given the st. George's situation, where the intrusion of the press lords had complicated the issue, Chamberlain in fact thought "that that would make things too difficult for S. B. to go and I did not anticipate that he would make up his mind to do so when he read the Memorandum." 44 It was, however, a

42. Chamberlain to Baldwin, 1 March 1931, Baldwin MSS, volume 166, ff. 47-9; original draft, NC 8/10/24.

43. Bridgeman to Baldwin, 29 March 1931, Baldwin MSS, volume $166, f .37$.

44. N. to Ida Chamberlain, 7 March 1931, NC $18 / 1 / 729$. 
feature of Baldwin's character that periods of complacency could swiftly change to a mood of deep despair at his position if confronted with a black picture from a trusted colleague - and his reaction to the Topping memorandum was in parallel with his reaction in september 1930 to Bridgeman's account of the position then - his spirits deflated to an apathetic low. He responded on 1 March to the Topping memorandum in the same way: gloomily convinced that he had fatally lost the confidence of his party, he resolved to quit at once. In the grip of this mood, he summoned Neville Chamberlain by telephone, and at three o'clock on 1 March 1931 told him of his intention to announce his retirement from the leadership forthwith. 45 That evening Baldwin discussed his plans for his future with his wife, considering retiring from the Commons also

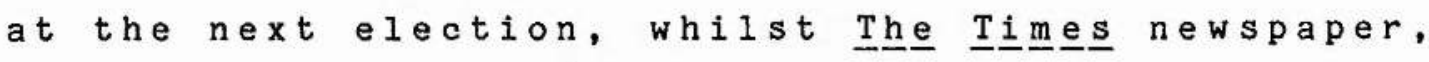
unofficially informed of the day's events, was setting its first leader for the following day, ready to announce that "Mr. Baldwin Withdraws". 46

As a consequence of Baldwin's dispirited reaction to these events, and decision of 1 March actually to quit,

45. Ibid; N. Chamberlain diary, 1 March 1931, NC 2/22. 46. Tom Jones diary, 11 March 1931. 
it has been too readily assumed that his position was in fact in real, rather than apparent, danger. Paradoxically, despite the evidence of his resolve to retire, his position was far from impossible. Baldwin could have ceased to struggle with the dissident elements in his party as a result of losing his personal morale and becoming depressed at any stage; this does not prove that this necessarily coincided with the period of his greatest peril. Baldwin had passed through the most serious phase of the party crisis in september-october 1930. The decision to withdraw taken on 1 March 1931 was the product first of low spirits, and second of misinformation and misconceptions of the reality of the situation. Naturally, when both these conditions ceased to apply, as they had by 2 March, the decision to resign quicklybecame a thing of the past. In appreciating Baldwin's apparent decision for retirement, the emphasis should be placed on the impact of events on Baldwin's mood and morale, rather than on any intrinsic significance in the events themselves as being of such gravity that they would inexorably lead to the fall of a politician of Baldwin's stature. Baldwin's resignation proved shortlived indeed, for the mood was broken that very same evening by Bridgeman and Davidson, who, by frankly presenting the other side of the picture, and deriding the necessity of resignation, dispelled such sentiments from Baldwin's mind like the mists before the dawn. 
Davidson had been present at Baldwin's house when he had received the Topping memorandum on the morning of 1 March, and recounted events that evening to Bridgeman, with whom he happened to be dining, "saying he supposedit was all up." 47 Bridgeman had never thought the position warranted resignation, although he had agreed when Chamberlain had consulted him that Baldwin should see the document. Bridgeman had kept his finger on the pulse of the rank and file - his wife was also prominent in the National Union Executive on the Women's side - and was "astounded" at the idea that after the victory at the second Caxton Hall meeting Baldwin "could possibly retire merely because Sir E. Petter had come out as a candidate for st. George's in order to challenge his leadership". After dining he and Davidson went at ten o'clock to Baldwin's house, finding "that Baldwin was contemplating immediate resignation". 48 Bridgeman rolled in "like an old Admiral", 49 and pooh-poohed the idea; if Baldwin had to go, he should at least go out fighting on some great issue, either in favour of his liberal policy on India, or in defence of the constitution against press dictatorship. In line with the latter idea, Bridgeman also offered a practical suggestion: Baldwin should resign his Worcestershire seat in order to fight in person the

47. Bridgeman journal, volume II, pp. 229-231.

48. Loc. cit.

49. Baldwin's own description to Tom Jones, Jones diary, 11 March 1931. 
vacancy at st. George's, "to challenge the right of the Press Millionaires to dictate procedure to the Party". 50 Such a proposal was entirely in line with Baldwin's own instincts, and within an hour Baldwin's mood changed, and he agreed not to go, but to fight. The Times went to press without any announcement of Baldwin's shortlived resignation, and Neville Chamberlain was summoned for 2 March, not to discuss the details of the succession problem, but the details of contesting st. George's. Bridgeman was correct in his analysis; the tide had turned in Baldwin's favour in the last week of February 1931 and the opportunity of playing the constitutional card against Petter at St. George's would accelerate the process. Baldwin's position was not without difficulties in the spring of 1931, but they were difficulties which could be overcome, and he now had solid advantages which he had not held in september 1930.

It will be appropriate here to analyse that turn of the tide, and consider the real nature of the threats to Baldwin's position in March 1931. The loss of confidence amongst the leadership and in the House of Commons, which has already been illustrated, was the principal danger to his position, but the tide of opinion within the party had begun to change within the previous fortnight, though it had not yet filtered through to the shadow cabinet. The principal reason for this was the East Islington by50. Bridgeman journal, volume II, pp. 231-233. 
election. Though this took place from the last week of January to polling on 19 February, the impact of the campaign and of the result, felt afterwards, superceded those sentiments which had given rise to Topping's decision to prepare his memorandum. When the vacancy had occurred at East Islington, the Conservatives were already prepared with an able and popular young candidate, Thelma Cazalet, who looked poised to win the seat from Labour and strike a blow at the tottering Labour government. The intervention of the press lords, despite the fact that Cazalet's policy differed hardly at all from theirs on fiscal matters, complicated the issue. Beaverbrook's first candidate was a respected local figure called Springman, who, sensing the hostility of local Conservatism to his nomination, rejected Beaverbrook and instead after only a few days in the field withdrew in Cazalet's favour; later he spoke for her at meetings. It was a blow for Beaverbrook, who seemed to have run into the sand. 51 Beaverbrook's response was swift but in the end counterproductive; finding another and much less reputable candidate and bringing him into the constituency as the crusade standard-bearer. The result was a bitter, and on occasion, violent campaign. Feelings and passion ran high over the election in the Conservative Party, both nationally and locally, and "the bitterness is

51. Lockhart diary, 5 February 1931. 
far worse than during South Paddington."52 Meetings were broken up, with fights breaking out between crusade stewards and Conservative hecklers, and on several occasions disorder spread into the streets in affrays and small riots.53 The disorder on the evening before the poll was described as "sensational street scenes" by one national newspaper, with "running fights". 54 one cause of this violent reaction, shared in verbal onslaughts from party leaders such as Hailsham, was Beaverbrook's misguided statement at one meeting that if he oould not force his policy on the Conservative Party, then he would set out to destroy it. Such sentiments naturally caused the party to rally together in opposition to the disunity caused by Beaverbrook's wrecking interventions. 55

The most serious consequence of East Islington was not the manner in which the conduct of the campaign placed Beaverbrook even further beyond the pale of respectable political tactics, but the result itself. Before the poll Neville Chamberlain had though that if the party should lose the seat due to Beaverbrook, "it may not be a bad thing, as it will certainly unite our people against [Beaverbrook], who has come out very badly on this

52. Ibid., 10 February 1931.

53. Morning Post; News Chronicle, 6 February 1931.

54. News Chronicle, 19 February 1931.

55. Templemore to Salisbury, 10 February 1931, Salisbury MSS, S(4) 139/83-84. 
occasion." 56 This was exactly what occurred; due to the split in the Conservative vote the Labour candidate held on to the seat at a time when Conservatives were increasingly desperate to chip away at the Labour government's majority and morale. In the words of the

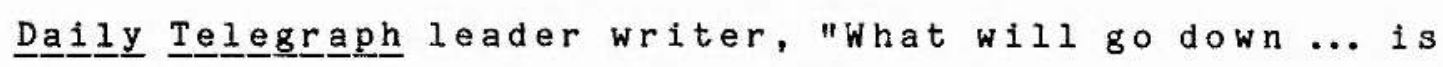
the Empire Cause. What will go up is the Socialist flag, and the worst Government with which this country has ever been afflicted will be encourged to believe that it is doing well."57 The result of East Islington was two-fold: it destroyed the appeal of the Crusade, and it produced a reaction in favour of the traditional Tory cry of party unity, which in effect meant a rally round Baldwin. It is perhaps not fully appreciated that it was the conduct and consequence of the Crusaders' intervention at East Islington that led to their final decline. Support for the Crusade at a local level amongst Conservatives support which had always been the real powerhouse of Beaverbrook's movement - had ebbed away continuously since october 1930. The East Islington fiasco put the Crusade in its coffin and the result nailed down the lid. The signifiance of the St. George's by-election a few weeks later was not that the latter brought about the defeat of the crusade, but rather that it exposed and exhibited

56. N. to Ida Chamberlain, 8 February 1931, NC $18 / 1 / 725$.

57. Daily Telegraph, 19 February 1931. 
publicly the reaction against it caused by East Islington in the month before.58 The reaction of grassroots Conservatism was a clear sign of the desire for unity above all other matters. In the wake of East Islington, right wing MPs such as Sir Robert Gower, announced their view that "there must be no division in their ranks". 59 The position in the constituencies was markedly different in tenor from that after the previous by-election split at South Padington in September 1930.60 opinions that the March 1931 crisis was more serious for Baldwin than that of September 1930 are in fact the erroneous product of viewing events too much from the parliamentary perspective. There was in fact a flow of supportive resolutions for Baldwin in February 1931, which even Topping acknowledged in his memorandum. These increased to a flood after the Islington result, and with the issue of press dictatorship coming once again to the forefront of politios in both the East Islington and the st. George's campaigns. 61

58. A similar pattern can be seen in two by-elections during the period of Conservative disunity over India, when due to the intervention of an independent Conservative, Labour gained Liverpool Wavertree in February 1935. A similar knock-on effect occurred at the by-election at Lambeth Norwood in March 1935 , eroding the support of the independent challenger.

59. Report of a meeting of Gillingham CA, 21 February 1931, Gower MSS.

60. Eye CA, Res., NU Exec., 12 May 1931; City of London CA, AGM, 14 February 1931.

61. East Midlands Area, Res. NU Exec, 10 February 1931; York CA Exec, 9 March 1931; South Kensington CA, Exec., 22 January 1931. 
It is in the light of this that the validity of the picture of party feeling portrayed in the Topping memorandum must be called into question. In parliament there was in February 1931 growing dissatisfaction with Baldwin's ability to lead, which was finding an avenue of expression in the complaints of the Diehard section over the bipartisan approach to Indian devolution. In this area there is no doubt that Baldwin's position was weak, though far from hopeless, as he was to demonstrate in March 1931. However, in other areas the Topping memorandum is open to serious doubts. It has already been lllustrated that the mood of the local associations was generally pro-Baldwin, and was far from the desperate picture painted by Topping. The party had not slipped back to the nadir of september 1930, and even if it did not enthuse about Baldwin, it preferred him to any other available candidate.62 The clearest indication of the calmer mood of 1931 can be found in the tone and resolutions of the meeting of the grassroots delegates at the National Union Central Council on 24 February - the day before Topping passed his memorandum to the Party Chairman.

Topping had been much influenced by an apparent falling-of of local association subscribers, which was being attributed to local supporters'disgust with the leadership. In fact, this was only the real cause in a

62. Denbighshire CA, Southern Area AGM, 21 March 1931. 
minority of cases. The party continually faced the problem of a fall-off in support in the mid-term of parliaments, in or out of office; and to that extent the financial alarms paralleled those of 1927-28 and 1932-33. On this occasion the problem was exacerbated by the economic slump which hit party subscriptions, rather than any political disillusion. In one region the explanation for the loss of revenue as dissatisfaction with the leadership was mooted, only to be dismissed:

In the discussion which followed it was suggested that this was merely being made an excuse, the real reason being that owing to the commerical depression, people were cutting down expenses, and made the first cut in their political subscriptions.

There were two further factors which may have caused Topping to exaggerate the disaffection in the lower ranks of the party. The first of these was the fact that he naturally was most familiar with sentiment in the region where he had formerly for many years been an agent himself, Lancashire, and with opinion in London and the suburbs, his immediate political environment. However, these two were the very areas where, for particular business reasons, anxiety about the party policy on India was a much more live issue than was the case elsewhere, where the issues of unemployment and protection and the related topic of government 'economy' were the vital

63. SuA, Eastern Div. Council, Treasurers Ctte., 12 February 1931. 
issues of the. day. The second reason for the darker picture painted by Topping was the fact that much of his information was recelved at second-hand from local agents, of whom it was often said that they tended to give too much weight to the vocal dissatisfactions of a minority whilst forgetting the loyal attitude of the silent majority of a local Association.64 Thus the evidence for a serious party crisis at all levels in February 1931 is far from convincing.

The real extent of the problem facing Baldwin was a loss of confidence by almost all his colleagues on the opposition front bench, by the officials of the party machine, and amongst a section of the parliamentary party. The extent of the disquiet on the Conservative backbenches is by its nature difficult to quantify, but the dissatisfaction with the leader's recent parliamentary and public performances, together with serious misconceptions over Baldwin's precise line on India, had clearly affected a much wider spectrum of opinion than the predictably dissatisfied right wing. However, this backbench mood was largely inarticulate, existing in a precarious position where it could be swayed one way or the other by the natureand effectiveness of the lead from above that it was given. For this reason, the attitude of the front-benchers was the crucial factor.

64. R. R. James, ed., op. cit., p. 357 . 
Once Baldwin decided not to quit, but to fight and to fight the supposed danger of Beaverbrook's threat from without, they had no option but to rally around the symbol, if not the persona, of the leader. In this sense, the Moore-Brabazon withdrawal gave Baldwin the tactical key to the situation. Moore-Brabazon's action did not, of course, represent a press attack, but was rather a further manifestation in public of the private disaffection of the parliamentarians. However, by switching the question at stake to that of press power, Balwin forced his colleagues to take their sides on the basis of that issue instead. Here there could be no sitting on the fence; in a polarisation between Beaverbrook and Baldwin after the events of winter and spring 1930-1931 there could be no middle ground for frontbench Conservative politicians, for the inevitable logic of the position meant that in defying the press lords they must, as their only path of action, support Baldwin. This was the significance of Baldwin's willingness to stand in person for st. George's; with Beaverbrook completely beyond the pale after East Islington, there was no surer device for rallying the Conservative Party around himself on a congenial, constitutional, issue. 65

65. Bridgeman journal, volume II, p. 233. 
The situation by the morning of 2 March was thus transformed from the shortlived mood of resignation of mid-afternoon on the previous day. With the sanctity of the constitution to be invoked, and the trumpet call of loyalty to be sounded, under a banner of 'pure' politics, the tactical balance had swung once more to Baldwin. The suggestion that he himself should fight st. George's in person as well as in spirit did not need to be put into practice to produce the desired effect. The suggestion alone had forced a redrawing of battle lines in which his colleagues, whatever their private opinions, must publicly support him. When on 2 March Baldwin informed Neville Chamberlain of his idea, the latter received it very unenthusiastically, but the product of it was that Baldwin's "late colleagues got a bad attack of second thoughts and cold feet, and begged him not to fight, and stated that it was impossible for him to go until after St. George's." 66 Neville Chamberlain and other leaders still believed that Baldwin's departure was only delayed, and would be inevitable in the near future, and it was in view of this consideration that Hailsham and Neville Chamberlain, in the light not of Baldwin's moves but of the "lobbying going on for Winston and Horne as successors", formally agreed to pre-empt the claims of the other two possible leaders by agreeing on 5 March to

66. Davidson to Irwin, 6 March 1931, Halifax MSS, India Office, Eur.C. 152/19/1/254. 
stand together. 67 In fact, the moment had passed, for in effect the intervention of the St. George's campaign gave Baldwin a breathing space to resolve his difficulties, now that his mood had changed to one where he was determined "not to go unless he was kicked out."68 By standing the leadership question over until after St. George's, the issue was actually settled in Baldwin's favour quite regardless of the outcome of the by-election campaign. If he, or his candidate, should win, then the matter of his going would after such a triumph be a dead letter. But what his colleagues overlooked was that it would be equally impossible to drop Baldwin as leader should the official standard-bearer lose, as this would be a surrender to the claims of the press lords, which all agreed could not be considered for a moment.

The first phase of Baldwin's restoration of his position was to find a suitable candidate to counter Petter and willing to support Baldwin's leadership at st. George's. This problem was rapidly solved. Baldwin had not, despite the complaints of some of the younger generation in the parliamentary party, lost the support of the majority of the rising figures of the centre and left of the party, several of whom having lost their seats in 1929 were available and keen to re-enter the

67. N. to Ida Chamberlain, 7 March 1931, NC 18/1/729.

68. N. Chamberlain diary, 11 March 1931, NC 2/22. 
House at by-elections. One of this number was Duff Cooper, who had little affection for the press lords on political or personal grounds, and who was noted in January 1931 as being "very pro-Baldwin".69 It is sometimes said that Cooper abandoned a safe seat he was nursing to take on a difficult prospect at St. George's, but in fact the reverse was the case. St. George's was an ideal constituency for a rising figure, and one of the safest seats in the country. Furthermore, given both the political issues that cooper could bring into play and his personal appeal, victory was almost a foregone conclusion. Social deference remained an influence in this constituency, with its closed-world attitude to social and society figures, in which man-about-town Duff, married to a Duke's daughter and leader of fashion such as Lady Diana, hopelessly outclassed Petter, an obscure manufacturer of diesel engines from the West Country. Given the view that the methods of the 'gutter' press of Beaverbrook and Rothermere were ungentlemanly, high society which might have been thought to favour Rothermere's Diehard right wing policies proved in fact more concerned with image and personality, and came down overwhelmingly on Duff Cooper's side.70 "The aristocratic houses of the 'Nobility' in Grosvenor Square have either in their windows or on their porches tvote for 69. Lockhart diary, 25 January 1931; Spender-Clay to Irwin, 5 March 1931, Halifax MSS, India Office, Eur.c. $152 / 19 / 1 / 251$.

70. Lookhart diary, 10 March 1931. 
Cooper'".71 In this constituency the combination of Duff and Lady Diana proved formidable; Duff himself was a good speaker, had a gallant war record, and amongst the generation of junior ministers was frequently spoken of as a coming man. Dawson described him as "a very good candidate", and thought that "he and the Lady Diana between them will succeed in pulling it of $" .72$

With his back secured at st. George's, Baldwin could thus address his energies to coping with the more serious problem facing him: the linked question of the confidence of the parliamentary party and the future of Indian devolution. The alarm over this had begun in the debate at the conclusion of the Round Table conference on 26 January, where Churchill's dissent had become manifest. Baldwin had on that occasion deviated from the agreed policy, and associated himself too closely with the Government, and his speech lamentably failed to reassure his followers. Baldwin attempted to restore his position with the party moderates, such as Hoare, though without compromising the spirit of his line on India, in the public speech fixed for 6 March. Although Baldwin's text at Newton Abbot raised no further alarms, and although it did not read well, being "a very commonplace speech", it improved the uneasy situation in which "the whole subject

71. Meynell to Irwin, 19 March 1931, Halifax MSS, India Office, Eur.C. 152/19/1/275.

72. Dawson to Irwin, 5 March 1931, Dawson MSS. 
[of India] is frightfully confused with the general antiBaldwin movement", by moving some distance to appease party anxieties over India. 73

For some time the Diehard discontent had been chanelled through the party's Indian Affairs Committee, where despite the efforts of the loyalist chairman, Wardlaw-Milne, the right wing was gaining ground in early March. It was a result of a meeting of this Committee on 9 March that Baldwin's prestige over Indian policy sank to its lowest depths. Either through carelessness, or a failure to realise its implications, Baldwin agreed that a resolution passed by the Committee at Churchill's original instigation be given to the press, despite the fact that it seemed to contain a reversal of his previous policy. Coming at such a time, it seemed to be a further example of Baldwin's weakness or simple incompetence; Lane-Fox wrote that "I was afraid that it was really the end of him."74 From this nadir Baldwin's position swiftly improved. The preliminary cause of this improvement was the conclusion of the agreement between the Indian Nationalist leader Gandhi and the Viceroy, Irwin, which appeared as a triumph for the liberal policy with which Baldwin had associated himself and his party. This made Baldwin's position much stronger and cut most of the ground from beneath the Diehard position. However, the 73. Dawson to Irwin, 13 March 1931, Halifax MSS, India Office, Eur.C. 152/1/1/268; see chapter 6 .

74. Lane-Fox to Irwin, 4 and 12 March 1931, ibid., ff. 246,266 . 
decisive improvement in Baldwin's standing with his Commons followers was his triumph in the debate in the House on Indian policy on 12 March. Baldwin's successful speech here was not only one of his best efforts, it was made to the very audience whom Baldwin needed to recapture - not the eleotors in st. George's, but the moderate majority of the backbench MPs. It was more than simply a successful exposition of Conservative policy, or even an accomplished demolition of Churchill - though it was both of these - the real value of the speech was that it showed fighting spirit, and exhibited Baldwin's willingness to assert himself: "the great thing was that he undeniably spoke as a leader."75 This speech proved the turning point, rallying to Baldwin's standard all but the most extreme Diehard section, and restoring the faith in him of moderate MPs: "it seems to have made all the difference to our own party".76 It cleared the issue of India out of the way in such a manner as to redraw the party divide not between Baldwin and the Irwinite fringe on the one hand, and the bulk of the party on the other, as had seemed to be the position after the debate of 26 January; but now so as to isolate Churchill and the irreconcilable minority of Diehards from the majority reconciled after the speech of 12 March to Baldwin's policy.

75. Stonehaven to Irwin, 17 March 1931, ibid., f. 271; Bridgeman journal, volume II, p. 235.

76. Freemantle to Salisbury, 14 March 1931, Salisbury MSS, S(4) 140/20-21; Earl of Avon, The Ede $\underline{\text { n }}$ Memoirs (1962), volume I, pp. 11-14. 
There remained no further barrier or inhibition to prevent the party rallying around its leader on the issue of the power of the press. The image of Baldwin in the mind of the grassroots in March 1931 was such as to place him in the role of a crusader "who was not afraid of doing his duty and who tried his best to clean politics."77 Attack from without usually had the effect of closing the Conservative ranks; typical of which instinct was the appeal for "all Conservatives to unite against the malicious attacks."78 put simply, this meant a desire "to make quite clear ... that they were Baldwinites and not Rothermereites".79 The strength of grassroots support for Baldwin in March 1931 is clearly evident in the chorus of resolutions supportive of both himself and Duff Cooper as candidate passed by $10 \mathrm{cal}$ Associations. 80 This rally to the leader was matched in the parliamentary party. A clear sign of the changed mood was the response of those

77. Chairman of Skegness CA, 25 March 1931, copy in Haslam MSS.

78. Bradford Central CA, AGM, 12 March 1931.

79. Denbighshire CA, Southern Area AGM, 21 March 1931.

80. Ealing CA, AGM, $13 \mathrm{March} 1931$; Northampton CA, Advisory Ctte., 16 March 1931; Reigate CA, AGM, 18 March 1931; York CA, Exec., 9 March 1931; Bradford East CA, AGM, $11 \mathrm{March} \mathrm{1931;Keighley} \mathrm{CA,} \mathrm{AGM,} 16$ March 1931; Flintshire CA, AGM, 14 March 1931; Wells CA, Exec., 17 March 1931; North Cornwall CA, AGM, 13 March 1931; SUA, Eastern Divisional Council, 13 March 1931; Lancaster CA, AGM, 21 March 1931. 
Conservative MPs who happened to be on the St. George's electoral roll, the division being a fashionable and convenient location for residence during the parliamentary session. Forty-five such MPs signed an open letter of support for Cooper's stand, representative of a broad spectrum of opinion. Only the Diehard fringe remained hostile, but reduced to impotence. Six Diehards resident in St. George's refused to sign the letter, of whom the most prominent was Gretton, though they made no public sign of hostility. 81 Only one MP stepped so far out of line as to give public support for Petter, the Diehard Sir William Wayland, and it was a clear sign of the changed mood of the party that this gesture nearly led to his repudiation by his local Association, as well as the withdrawal of the party whip. 82

Whilst Conservatism was in the process of rallying around its leader, the attack on Baldwin at St. George's and in the columns of their newspapers was badly mismanaged and misconceived. Beaverbrook was now paying the full price of his dependence on Rothermere, first in the way in which hostility to the latter tarred the former by virtue of the association, and second in the fact that

81. Letter and signatories of support, Morning Post, 16 March 1931; list of those who refused to sign enclosed in Gower to Fry, 19 March 1931, Baldwin MSS, volume 51 , f. 119 .

82. Canterbury CA, Emergency Meeting, 28 March 1931. of all the local associations surveyed, there was only one where evidence of reluctance to support Baldwin larger than in a tiny and isolated minority was found; East Dorset, and this seems to be largely the influence of the Diehard local MP. 
Rothermere was diverting the campaign on to other issues. Empire Free Trade was pushed into the background by the India issue, which was heavily run by both Petter himself and the Daily Mail throughout the campaign, culminating in the slogan "Gandhi is watching st. George's".83 The balance of power in the alliance between the two press lords was swinging from Beaverbrook to Rothermere, who was able to insist on Beaverbrook promoting the issues of India and 'national economy' to the forefront.84 Beaverbrook was aware that Rothermere "put more stress on India than on Empire Free Trade", but needed to appease his only remaining ally.85 India, however, was no longer such a good stick with which to beat Baldwin, and Beaverbrook later felt that he had made a fatal mistake: "We were baffled by cross-currents all through the campaign, and we were driven far from our course." 86 He admitted "the defeat is due in part to my own stupidity: it was wrong of me to fight on India and the leadership of the Conservative Party." 87

The second area in which the tactics of the press lords were misconceived lay in the social composition of

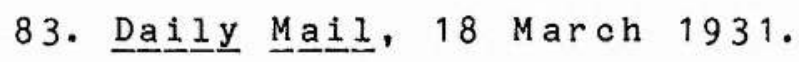

84. Rothermere to Churchill, 31 January 1931, Churchill MSS 2/180.

85. Beaverbrook to Rothermere, 27 February 1931 , Beaverbrook MSS, C285.

86. Beaverbrook to Parker, 23 March 1931, ibid., C267.

87. Beaverbrook to Pinckard, n.d. but c. 25 March 1931 , ibid., B203. 
the constituency. Though a metropolitan division, it was not ideal Crusading territory; the influence of the Daily Maiㅛ and 므름 Express was not as great here as in many middle class constituencies of the Paddington type. In st. George's the leaders of opinion in the upper olass residential areas tended to be readers of $\underline{T}$ he Times and Morning Post, both of which were not only staunchly proBaldwin, but also accepted his contention that the issue of the day was indeed the constitutional role of the press. 88 Apart from the wealthy quarters of Mayfair, the constituency also contained some working class housing in Pimlico. Here Petter may have picked up some votes, though most Liberal and Labour potential supporters would not have been attracted either by anti-Baldwinism or a hard line on India. However, one product of the hostility shown to Beaverbrook by the aristocratic element was his adoption of an even more demagogic, even populist, platform in his attempts to win over Pimlico, further alienating himself from the conventional and deferential Conservatism of respectable society.89 The greatest weakness of the Petter campaign was that the keynote was personal rather than political. This was not only counterproductive in itself, but it also gave Baldwin an excuse for making a personal intervention in the

88. Morning Post, 18-19 March 1931.

89. G. Peele, "St. George's and the Empire Crusade", in C. Cook and J. Ramsden, eds., By-Elections in British Politics (1973), pp. 99-100. 
constituency. Baldwin spoke at the Queens Hall on 17 March, two days before the poll, and made the theme of his speech a denunciation of the press lords' methods.

The significance of the Queens Hall speech, and in particular the short extract from it where Baldwin castigated the press barons for aiming at "power without responsibility - the prerogative of the harlot throughout the ages", has, however, been consistently overrated by historians, amateur and professional. Baldwin did not crush the Empire Crusade by means of a phrase, or even a speech, however pungent and striking. Phrases from speeches in this period did not normally have that kind of direct impact electorally, unless hammered home repeatedly in the media and through other forms of propaganda. Baldwin's almost vulgar summation received no such prominence at the time.90 Contemporary observers considered it a minor, not a major, contributor to Cooper's campaign and Baldwin's re-establishment, if they thought even that. Hannon wrote, "I do not think Baldwin's speech will make a shadow of a difference to the battle in st. George's." 91 It was only one small part of Baldwin's strategy of raising the argument from the details of policy - whether it be tariffs or India - to

90. For example, as treated by the Daiily Telegeraph and Morning Post, $18 \mathrm{March} 1931$.

91. Hannon to Beaverbrook, 17 March 1931, Beaverbrook MSS, C 155 . 
presenting it in the context of the constitution. Once he had succeeded in changing the nature of the controversy, in which the misconceived tactics of his enemies assisted him enormously, the latter were exposed in a politically untenable light. The 'harlot' passage, and indeed the entire Queens Hall speech, is significant rather as a supreme example of the defence that, by decision or instinct, Baldwin adopted against his critics. The impact of the 'harlot' phrase was not upon the election of st. George's, but upon posterity. In retrospect, it came to encapsulate, even for the politicians involved in these events, the keynote of the party crisis. By taking it so frequently out of context, due to its virtues of brevity and almost shocking pungency, later memoirists and commentators used it to sum up the events of both 1930 and 1931, thus giving both the speech and with it the st. George's by-election an irresistible impetus towards achieving historical importance. Yet this significance was far from clear at the time. The St. George's election was largely won in other ways: by the personality of the candidate, not the least. In one sense, it was probably won for Baldwin even before it began, in the sense that it was the fracas at, and result of, East Islington that exposed the Crusade as a dangerously irrelevant political luxury and produced the reaction against it exhibited at St. George's. On these terms East Islington, and not st. George's was the crucial contest. To it must be largely 
awarded both the existence and the scale of Duff Cooper's victory on 19 March 1931.

ST. GEORGE'S Turnout - 53\% Electorate $-54,156$

\begin{tabular}{llll} 
A. D. Cooper & Cons. & 17,242 & $60 \%$ \\
Sir E. Petter & Ind. & 11,532 & $40 \%$ \\
& & \\
\multicolumn{2}{l}{ Cooper's majority } & $\underline{5,710}$
\end{tabular}

In fact, if any speech added to Cooper's majority, it was Baldwin's successful House of Commons performance on India. So far as the press was concerned, it seems clear that the personal attacks on Baldwin were counterproductive. Baldwin's true victory at St. George's was that a majority of the electors, and almost all his own party, accepted his analysis of the party crisis, its causes and therefore its solutions. This was a double victory, in that more and more as the precise details of the complicated sequence of events of 1929-31 receeded into memory, the correctness of Baldwin's reasoning and stand become also more and more accepted fact.

The other reason why the importance of st. George's is so consistenly over-rated is the fact that in the week immediately after it, Beaverbrook re-opened negotiations and made peace with the party. On this occasion, with both sides in a chastened mood after the result and reaction at East Islington, topped of $f$ and confirmed by st. George's, the prospects for concluding a deal on both sides were brighter than ever before. This was not the 
direct product of st. George's itself, but rather the whole trend of events since October 1930. Having removed the policy difference, Neville Chamberlain had long wanted to secure a deal, but felt no particular urgency in the matter until East Islington proved that Beaverbrook still had sufficient influence in the metropolitan and home counties' electorate to dangerously damage Conservative

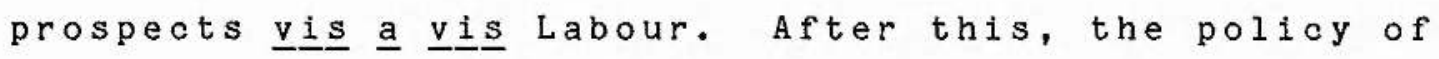
December of letting things "drift" seemed no longer appli able. On Beaverbrook's side, two successive failures, and the accompanying bitterness, finally convinced him that his strength had passed the peak of South Paddington. The continuous strain of running his one-man campaign was also telling, and his mood was at least temporarily inclined to seek another truce. On $22 \mathrm{March}$, at Hoare's suggestion, Neville Chamberlain sent Beaverbrook a note suggesting a talk. This was quickly responded to, and the two men met on the 24 th at Beaverbrook's residence, Stornoway Hou'se, where during the following week most of the negotiations took place, and which gave the agreement eventually concluded the name of the Stornoway Pact.

The basic agreement was drafted on $24 \mathrm{March}$, and hinged on Beaverbrook's developing concern over the position of British agriculture, by now his principal interest. The agreement oontained nothing that was not already implied in the Conservative agricultural policy and the free hand policy on tariffs, but Beaverbrook halfheartedly attempted during the week after the meeting of 
24 March to amend the drafted exchange of letters in such a way as to make it appear that he had scored a victory. 92 In this he was to some extent encouraged by the newly formed Agricultural Party, based in Norfolk; but at this stage the desire for a truce was greater than the desire, sometimes contemplated, to fight to the end by "adopting Sinn Fein tactios".93 Thus when Neville Chamberlain, aware of the strength of his position, firmly resisted these modifications, Beaverbrook's resistence crumbled. The difficulties over Taylor's position at south Paddington which had proved the stumbling block on the last occasion were now swept aside, to be dealt with after a general settlement. Chamberlain secured the agreement of the shadow cabinet to the proposed exchange of letters between himself and Beaverbrook, and, after further meetings at Stornoway House, these were given to the press on 31 March. Chamberlain had moved swiftly, exploiting the mood he sensed in Beaverbrook, flattering and then bullying him into an agreement which was made public immediately, and from which Beaverbrook would have much more difficulty disengaging than the previous truce of Maroh 1930.94 Neville Chamberlain himself had no doubt that "the pact with Max was a real victory ... Baldwin

92. Beaverbrook to. Londonderry, 25 March 1931, ibid., C224.

93. Lockhart diary, 24 March 1931.

94. N. Chamberlain diary, 25, 28, 31 March 1931, NC 2/22. 
has given up nothing. It is Max who has now accepted our policy." 95

At the same time as peace was declared in the external squabble, so it was also secured internally. There had been no plot against Baldwin, only dissatisfaction with him on the part of his colleagues; but in his fighting mood after 2 March Baldwin misinterpreted the statements and actions of several colleagues, including Neville Chamberlain and Hailsham, as having been disloyal to himself. One reason for this was a sudden and unexpected intervention from Austen Chamberlain at the shadow cabinet on 11 March, at the height of the crisis, in which he demanded to know when Baldwin would release his brother Neville from the confining position of Party Chairman. This additional complication was not, in fact, a stab in the back at Baldwin, but a spontaneous and unrelated move by Austen, which Neville himself did not expect, and did not entirely welcome.96 It was the product of Austen's frustration at the general situation and of his repeated fears that Neville was damaging his own prospects by his tenure of the Chairmanship - which Austen had always thought a bad move - but from which he could not see how to extract his younger half-brother.97 By the height of the crisis 95. N. Chamberlain to Derby, 10 April 1931, in R. Churchill, Lord Derby (1959), p. 587.

96. N. Chamberlain to Baldwin, 13 March 1931, Baldwin MSS, volume 166, ff. 58-61.

97. A. to Hilda Chamberlain, 7 March 1931, AC 5/1/533. 
Austen was disturbed lest Neville be dragged down with Baldwin, and took the first available chance, however maladroitly, to prevent this. There was no intrigue behind this move, nor was it connected to Neville's previous presentation of the Topping memorandum. Baldwin, however, felt threatened by and resentful of the attitude of his colleagues, and allowed his resentment to become open knowledge. This in turn exacerbated their feelings, and in particular led to a period of personal coolness between Baldwin and Neville Chamberlain, in which the latter, believing he had lost his leader's confidence, indicated that, the matter having been raised, he would like to quit the Chairmanship. Paradoxically, it was this which led to a clearing of the air. After the dust had settled at st. George's, Neville Chamberlain, piqued at Baldwin's apparent loss of confidence in him which he considered his loyal conduct did not deserve, had a blunt private talk with the latter on 24 March. Baldwin was now keen to avoid any rift, and when Chamberlain put his grievances before him, responded apologetically. This revision was a considerable success, Chamberlain noting that "we parted shaking hands and with the clouds removed", to their mutual relief. 98

This strategy was repeated at the shadow cabinet meeting of $25 \mathrm{March}$, in which Baldwin's colleagues were able to vent their frustrations verbally to him, a process which reduced the pressure of their discontent by the 98. N. Chamberlain diary, 25 March 1931, NC 2/22. 
relatively harmless process of letting off steam: "everyone felt better after it, except S. B."99 However, it was Baldwin who had in real terms gained most from these events, both from the external settlement and the internal clearing of the air. He had been forced to concede nothing of consequence, and his position and powers had remained intact. The price of hearing some critical comments was not a high one to pay for reestablishing his pre-eminence as leader and preserving the solidarity of the front bench. Bridgeman perceptively analysed the realities of the position at the end of March, 1931:

I think it can be assumed that they have said all they mean to say, and will now come into line. I noticed that they all spoke of you as their leader ... you are in a more secure position.

The crisis had become a thing of the past, as had talk of Baldwin's retirement, and there was "a general atmosphere of relief". 100 In the face of impending national crisis, economic and political, unity came above all else in Conservative politios in 1931. This was the lesson taught by East Islington, tested but accepted on the issue of India, and confirmed at St. George's. In such a period of 'national peril', internal party dissent was an unnecessary luxury. It was in this mood that, after March 1931 Baldwin and his colleages set about the restoration of order in Conservative politics.

99. N. to Hilda Chamberlain, 28 March 1931, NC 18/1/732.

100. Bridgeman to Baldwin, 25 March 1931, Baldwin MSS, volume 166 , f. 36 . 
PART TWO: THE RESTORATION OF ORDER 
CHAPTER 6

National Peril: (i) The Imperial Dimension

The domestic implications of tariff reform, as discussed in the previous chapters, were the constant anxiety of the pragmatic element in the Conservative party, a group predominant amongst the leadership. In the domestic dimension it is accurate to portray the struggle for mastery of party policy as being between the economic appeal of protectionism, both to the agriculturalist and to the safeguarded industrialist, and the political dangers summed up by the 'dear food' cry. Whilst there is little doubt that considerations of domestic politics governed the pace and extent of the party's commitment to fiscal change, these concerns were a secondary factor for the committed protagonists of tariff reform. Tariff reform was above all a great imperial ideology, originating in concern over the future development of the empire, and it was in this context that it captured the idealism of its most fervent advocates, such as Amery, Page Croft, and even Beaverbrook himself. The purpose of such a policy, the prize for which domestic political risks were to be run, was imperial consolidation and unity, and the debate over tariff reform can only be integrated properly with Conservative political action by placing it firmly in the imperial dimension. In this context imperial preference through tariffs was only one aspect of a wider series of questions concerning the 
future of the British empire which faced Conservative politicians in an especially acute form during the period 1929-1931. Anxiety was heightened by the supposed dangers of Socialist control over official imperial policy, but quite apart from the normal frustrations of opposition was a growing sense that the future of the empire was at the crossroads by 1930. The internal crises affecting the empire, the external threats endangering it, and the degeneracy of the home country's will to give it a lead, provided the imperial dimension of the peril facing the nation as perceived by Conservatives between 1929 and 1931.1 The problems of empire in relation to the weakness of both the economic resources and political determination at home were felt to be crucially apparent at this time. These problems concerned the question of imperial defence, bound up in the negotiations over the size of the navy at the London naval conference of 1930, and the difficulties facing imperial policy in East Africa, Rhodesia, Palestine and Egypt. Above all, the future relationship of the two most important constituent elements in the empire to the mother country were at issue in this period: in the case of the self-governing dominions over imperial preference, and in the case of India over the political role of the native population. Given the range and significance of these concerns, it was possible to react in terms not of a

1. Hoare to Willingdon, 2 September 1931, India Office Library, Templewood MSS, Eur. E. 240. 
series of localised questions, but of a general imperial crisis - even of conspiracy:

it is not only in India that the situation causes disquiet, or perhaps it is partly owing to our Indian difficulties that our enemies elsewhere show their sinister countenances. Malta, Egypt, Palestine, even in Cyprus or Iraq - in each the situation presents particular and potential dangers.

But of all these areas India was the real lynchpin of empire, and thus the debate over the political evolution and devolution of India assumed such cardinal importance in Conservative party politios, alongside the question of imperial preference for the dominions.

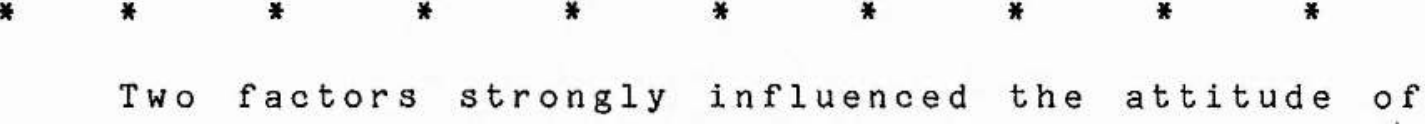
Conservatives towards the India question in 1929. The first of these was the parallel with the question of Ireland during the previous fifty years. Baldwin in particular drew the lesson that for the health of the empire such matters must not become the stuff of party disputes. Yet from the perspective of the imperialist wing of the party, the lessons drawn from the Irish treaty were quite different. Here the emphasis was placed on the importance of strength and consistency, and the purity of a policy of not negotiating with disaffected elements:

We bought peace in Ireland by negotiations with evil forces of assassination. We are paying now a long price in India and Egypt today. If we are now

2. Balcarres to Irwin, 13 May 1930, Halifax MSS, India Office, Eur. C. 152/19/1/57a. 
to repeat the performance in India, where next shall we be called upon to pay the Bill?

From such a perspective Baldwin's self-confessed aim "of trying to liberalise the Tory Party" on India 4 appeared as stark defeatism; looking back on these events Churchill painted the distinction in this light:

So far as I could see, Mr. Baldwin felt that the times were too far gone for any robust assertion of British Imperial greatness, and that the hopes of the Conservative party lay in accommodation with Liberal and Labour forces.

In the sense that Baldwin prized the preservation of consensus at home on imperial policy this was true, although Baldwin expected that the other parties, equally aware of the need for unity, would moderate their course in the light of Conservative fears and requests for safeguards, and meet them half way.

A second factor also carried much weight with Baldwin, and with the viceroy he had himself personally selected and sent to India, whilst still Prime Minister, Lord Irwin. Both felt that the implications of British policy in India in the past limited their freedom of 3. Lloyd to Baldwin, 5 March 1931, Baldwin MSS, volume 104 , ff. $226-227$.

4. Lytton to Irwin, 20 November 1929, Halifax MSS, India Office, Eur. C. 152/18/1/309.

5. Churchili's recollections, Churchill MSS 4/113, in Gilbert, op. cit., pp. 25-26. 
manoeuvre in the present. Irwin admitted that "we very likely made a mistake when we gave Indian education and thought its western twist, but having done so the kind of results we now see today are inevitable". ${ }^{6}$ In particular, the events during the 1918-1922 coalition government were felt to have determined the pattern of Indian development. The Montagu-Chelmsford reforms "had set our feet upon the permanent road" of devolution, whilst the reaction to the Armitsar massacre had sounded the death knell of any reliance upon pure repression of native political opinion. 7 In the case of both precedents, it could be said that in the matter of India, just as over tariff reform, the division in the Conservative party lay between the pragmatists, surrounding and influencing the party leader, and the purists or idealists, who were normally kept in the position of a vocal fringe group, and that in both areas of the imperial dimension the leadership managed normally to retain the crucial confidence of the moderates or central mass of the party, in the Commons and in the constituencies.

The question of India became acute in late 1929, with the first definite forward move since the MontaguChelmsford reforms. This was the decision of Irwin that, notwithstanding the fact that the statutory

6. Irwin to Hugh Cecil, 29 August 1930, Halifax MSS, India Office, Eur. C. 152/19/2/136e.

7. Irwin to Churchill, 26 December 1929, ibid., Eur. C. $152 / 18 / 2 / 419$. 
Commission presided over by Sir John Simon and representatives of all three parties, which had been set up to recommend the next stages of Indian constitutional reform, had not yet reported its conclusions; it had become necessary to pacify and reassure Indian native opinion of the British government's sincerity by making a formal announcement accepting that India should evolve towards dominion status. Irwin had come to this conclusion earlier in the year, and had discussed his ideas whilst in England in the summer of 1929. With leading Conservative politicians, including Salisbury and Baldwin, for he laid much emphasis on the need fior securing domestic unanimity. ${ }^{8}$ Baldwin was in any case sympathetic to Irwin's proposal on two counts: to Irwin in person, and to his policy. Baldwin admired Irwin, and trusted his purity of motives as well as his judgment. 9 Even before the election in May 1929 Baldwin foresaw that India would be a crucial issue in the next parliameint, and had indicated privately his support for Irwin's policy. 10

The question of Irwin's declaration was complicated by the fact that the crucial decisions over the content and timing of the announcement, and the predise role and 8. Memo of conversation with Irwin, 28 July 1929, Salisbury MSS S(4) 197/103; Irwin to Baldwin, 19 September 1929, Baldwin MSS, volume 103, ff. 58-59.

9. Baldwin to Irwin, 26 June 1927 and 10 May 1931, Halifax MSS, Borthwick Institute, A4/410/14/2, A $2 / 278 / 24$.

10. Baldwin to Irwin, ibid., A4/410/14/3; Dawson to Irwin, 8 April 1929, Dawson MSS. 
attitude towards it of the Simon Commission, occurred during the later stages of the parliamentary recess in September and early October 1929 with the principal politicians out of close contact with each other: MacDonald in the United States, and Baldwin as usual holidaying at Aix-les-Bains. Whilst Baldwin was journeying back from the south of France, he was met at Bourges by an emissary from the: India office, bringing a copy of the proposed statement, and seeking Baldwin's approval in his capacity as leader of the Conservative party. The result of this meeting was a series of misunderstandings. It is apparent that while supporting Irwin, Baldwin pointed out that in the absence of his colleagues his approval could only be in a personal capacity; and that there was confusion over the extent to which simon had been consulted, either officially or unofficially, and whether or not his attitude was hostile. Baldwin's approval did not thus commit his party, and "the assent, such as it was which [he] gave was conditional on the approval of Simon and the Commission". 11 However, the government did not fully comprehend these reservations, and Baldwin either misunderstood, or was deliberately or accidentally misinformed of the position of the simon Commission, and as a result thought that they acquiesced

11. A. Chamberlain to Peel, 30 October 1929, AC $38 / 3 / 115$. 
in the new initiative. As Cunliffe-Lister later commented, "it was all rather a muddled business". 12

After Baldwin's return rumours of his action, based on the government's interpretation of it, resulted in a stormy and unhappy session of the shadow cabinet in the last week of October 1929. Few amongst the Conservative leaders were content either with Irwin's proposed statement or with the fact that the party's hands were largely tied by Baldwin's Bourges commitment, be it a personal one or not. In this sense the incident is a clear indication of the enormous personal power of the party leader, for Baldwin's decision gave his followers little room for manoeuvre by making the issue as much one of confidence in, or rebellion against, himself as leader, as a question of support for Irwin. At the same time Baldwin's caveat allowed him an avenue for retreat should he be unable to carry his party, for he could fall back on the defence that his views had been private ones only, and drop them for a more cautious policy. In fact, he executed a combination of both manouevres. Having taken the temperature of his colleagues at the shadow cabinet meeting, he allowed Austen Chamberlain to draft a letter to be sent to Snowden, who was acting Prime Minister in MacDonald's absence, which underlined and placed on the record the qualifications he had made at Bourges.13 This 12. Cunliffe-Lister to Irwin, 28 December 1929, Halifax MSS, India Office, Eur. C. $152 / 18 / 1 / 344$.

13. A. Chamberlain to Peel, 30 october 1929, AC $38 / 3 / 115$. 
appeased his colleagues, and preserved a thin facade of party unity over India, which was Baldwin's real desire. Although the consequence was not without considerable risks, and although the misunderstandings at Bourges undermined confidence in Baldwin's capacity, 14 and the price paid for this was a period of strain within the party, nevertheless Baldwin had succeeded in holding the Conservatives to a line of polioy that would have been almost unthinkable six months previously, by a classic exploitation of his position as leader.

Thus when the declaration was made by Irwin in India on 31 october 1929, although it came as a bolt from the blue to uninformed opinion in Britain, in the press and on the backbenches, the hands of the Conservative party were already largely tied. There can be no doubt that the Irwin declaration caused the greatest misgivings in Conservative circles. Hoare, one of the few of the front bench to support Irwin's policy, nevertheless admitted that "scarcely anyone in the party liked it" and that "the Diehards were much upset". 15 The onslaught against the Irwin declaration did not, however, originate from the Diehard Tory MPs, but from three other quarters. The first of these was a group amongst the party leadership with some experience of Indian affairs, who were by coincidence the same personalities identified with the 14. Lane-Fox to Irwin, 7 November 1929, Halifax MSS, India office, Eur. C. 152/18/1/292.

15. Hoare to Irwin, 13 November 1929, ibid., f. 298. 
hey-day of the Lloyd George coalition: Austen Chamberlain, Winston Churchill, and Lord Birkenhead. The fact that the second source of domestic objection came from the Liberals, from Lloyd George and the former Liberal viceroy, Lord Reading, lent substance to fears of a coalitionist intrigue. However, the most serious attack of all came from the Daily Mail, which exposed the entire question of Baldwin's actions at Bourges, in an article entitled "Baldwin's Crowning Blunder", which shook party confidence and morale with its specific, and presumably leaked, allegations that Baldwin had committed the party without consultations or reservations to the Irwinite line. In fact, the action of the Daily Mail in making the central issue the manner of Baldwin's commitment, more than the validity or otherwise of the policy he had supported, was a grave tactical error. At first sight it may have seemed his most vulnerable point, but the tactic failed miserably. In the first place the Daily Mail's charges cut across and pre-empted the more serious and weighty criticisms of Reading, Birkenhead, and the rest of the Conservative press. 16 Thus, whilst on 1 November the leader in the Morning Post denounced "this folly of Dominion status", on the following day it reacted against the ㅁa표모 Mail attack, dimissing it as "another proof of the malignity with which the Conservative leader

16. Balcarres to Irwin, 8 November 1929, Halifax MSS, India Office, Eur. C. 152/19/1/162a; Daily Telegraph, 1,2 November 1929. 
is pursued". 17 This underlined the fact that the very style and source of the attack from Rothermere had the effect of pushing the party together in a reflex reaction of solidarity against outsiders. Dawson, the editor of The Times, commented on the Daiㅣㅁㅡ Maiili; "these inept politicians always overdo it and the result is an instant reaction". 18 And indeed, this proved to be the case, for the Daily Mail's charges were in fact refutable by Baldwin - in detail, if not in spirit; thus the attack on the declaration was blocked at square one. Furthermore, Baldwin exploited this tactical advantage by making his counterattack a part of his Commons speech on the debate on the Irwin declaration, and was thus able to hamer the newspaper without fear of a response.

The Commons debate on the Irwin declaration was a success for Baldwin, who produced one of his periodic oratorical masterpieces for the occasion, translating the debate to "an unusually high level". 19 Lane-Fox wrote that "the outstanding speech was S. B.'s who not only rose to real eloquence... but also raised his position in his own party very much", whilst the Daily Mail was "entirely demolished". 20 Despite this success, however, there was

17. Morning Post, 1, 2 November 1929.

18. Dawson to Irwin, 3 November 1929, Halifax MSS, India Office, Eur. C. 152/18/1/290.

19. A. to Ida Chamberlain, 11 November 1929, AC 5/1/486.

20. Lane-Fox to Irwin, 13 November 1929, Halifax MSS, India office, Eur. C. 152/18/1/299. 
nearly a serious party split, for the dissident former coalitionists looked prepared to lead the Diehards into the same hostile lobby as Lloyd George if a division was called. In the event, at the end of the debate this was avoided, in part because the party instinctively shrank back from any overt split, and in part due to the widespread suspicion that the manoeuvre was designed to bring back the old coalitionist alliance and reverse the verdict of 1922.21 From this high point the crisis over the Irwin declaration receded, leaving the Conservative party committed to the principle of the government's policy of summoning a Round Table conference to discuss Indian devolution, yet without there being any damage or "any permanent effect" upon the party.22 Baldwin succeeded in keeping discontent under control by the combination of four factors. The first of these was his exploitation of his position as leader and of the loyalty given to him; the second was his exploitation of the hostility of the party to the Dai픔 Mail itself; the third was the exploitation of the fear of coalitionist intrigue; and the fourth and perhaps most important was the party's instinctive fear of disunity in the voting lobbies. Underlying these facts, however, was evidence

21. Winterton to Irwin, 11 November 1929, ibid., f. 295; Dawson to Irwin, 31 october 1929, Dawson MSS; Davidson to Irwin, 9 November 1929, Davidson MSS.

22. Hoare to Irwin, 13 November 1929, Halifax MSS, India Office, Eur. C. 152/18/1/298. 
that the anxieties over India were both real and widespread, with "considerable unrest among the Diehard element ... and even the more moderate backbenchers were in a state of suspended animation." 23 Baldwin had secured his position, but only in the first engagement of a long campaign.

Baldwin's position of maintaining public unity at home was not without support. It appealed to the party's own self-image that it should sacrifice possible domestic political advantages, that it "would approach the position solely from the point of view of the good of the Empire as a whole, and in particular India".24 of course, one section of his party fundamentally disagreed that the bipartisan approach was in fact in the interests of the empire - but there was enough solid evidence to suggest that it was to convince not merely Irwinites, but the more crucial uncertain centre figures. Hailsham, who carried much weight with the party's right-of-centre, accepted the need to keep public opinion at home united, and was realistically aware of the dangers of striking out on a hard-line polioy, having few illusions about "the possibility of maintaining orderly government in India if we were in office and both opposition parties were supporting the Indian extremists in refusing to obey our

23. Davidson to Irwin, 9 November 1929, Davidson MSS.

24. Memo of conversation between Davidson and Stopford, secretary to the Simon Commission, 4 November 1929, Davidson MSS. 
rule or co-operate in the form of Government which we sought to impose." For Hailsham, as for most Conservatives, the crucial questions concerned the necessary safeguards, in the field of control of foreign and defence policy in particular, which would have to be built into any Indian constitution, "and that no constitution which does not adequately provide for these can be accepted". 25 Thus the debates of the next five years centred around this matter of essential safeguards, leaving the objectors to any kind of advance for India at all as an excluded fringe.

The moderate Conservative line on India became synonymous with Sir Samuel Hoare. Indeed, Hoare built his career upon his careful treading of a median line in the party over India, so as to be able to carry the right wing with him in a policy of cautious advance. As early as December 1929 Hoare was determined to carve out a niche for himself as the future Conservative Secretary of State for India.26 In his public utterances he was careful to admit to "doubts and fears" over India, and seeking to put "a brake on demands for ill-considered advance". 27 At the same time it is clear that Hoare sincerely respected Irwin's viewpoint, even if he did 25. Hailsham to Salisbury, 2 April 1931, Salisbury MSS $S(4) \quad 140 / 58-61$.

26. Hoare to Irwin, 24 December 1929, Halifax MSS, India office, Eur. C. 152/18/1/339.

27. Hoare, "The Future of India", Chelsea CA, Newsletter, March 1931. 
not think it completely practical politios, and sought to keep in close contact with the viceroy. Between 1929 and 1931 Hoare gradually took over the front bench spokesmanship on India, a position which both enhanced and reflected his growing stature within the party. Significantly he, together with other ambitious younger figures, chose to follow the path of promotion by adhering to the party orthodoxy, rather than rebelling against it. Hoare was

quite justifiably keeping his eye on the position which he is creating for himself ... in some ways much more advanced than [the Diehards] but in others not so idealistic as Mr. Baldwin himself and some of the younger men.

If in Hoare's strategy there was a strong element of ambition, it was a drive that was to prove of inestimable assistance and value to Baldwin in maintaining his hold upon the party.

India was pushed from the centre of the political stage after the Irwin declaration by other issues - for the Conservatives in particular by Beaverbrook's campaign - until the convening in London of the Round Table conference almost a year later. In between there was a minor flurry over Gandhi's salt campaign in March 1930 but the combination of firm action by the Indian

28. Hailey to Irwin, 6 January 1931, Halifax MSS, India Office, Eur. C. 152/19/1/201. 
authorities with a carefully managed debate in the Commons, in which backbench MPs were able to express their concern, ensured acceptance of Hoare's argument that the incident should not deflect the agreed and accepted programme. ${ }^{29}$ This incident merely underlined the trend of this intervening year, during which the balance of forces within the party tilted slowly but decisively in favour of the Baldwin-Irwin line. The cause of this change was the gradual commitment of the party, almost without its noticing it, to a bipartisan policy on India, which had the effect of largely removing the issue of India from the arena of party politics. So far as it could be a political question at all, it became perforce after November 1929 a question within the Conservative party, in which a numerically small and poorly led Diehard group challenged the wisdom of the front bench. The consequence of this was to press the party centre into support for Baldwin's line. This crucial support he maintained during the following six years of party debate over India, although on occasion he came close to losing it. Decisions over India policy were taken in an atmosphere of co-operation between the front benches:

The main reality is that the decision about Indian Government will be taken here in England; and that the real sovereignty of India lies here .... I suppose if ten persons or thereabouts on Front

29. Hoare to Irwin, 31 May 1930, ibid., f. 71. 
Benches come to any decision about India, that decision will in fact operate.

wrote Hugh Cecil, although he added one crucial proviso:

No doubt public opinion on some questions greatly influences and sometimes overbears Front Benchdom: but at present, at any rate, public opinion is not excited [about India]

No major politician questioned this analysis, for it was the aim and intention of Winston Churchill, the only important front bench rebel against the bipartisan line, to arouse the sleeping lion of British imperial sentiment, as the only available means of breaking the solidarity of the parliamentary consensus over India.

Winston Churchill was, in the year between the Irwin declaration and the Round Table conference, politically a declining figure, looking for an issue with which to revive his career. He was unpopular with all sections of the Conservative party; with his colleagues in the shadow cabinet, with the MPs with the imperialists and the protectionists, and with the rank and file. His period as Chancellor of the Exchequer in Baldwin's 1924-1929 government had not endeared him to the party grassroots. 31

30. Hugh Cecil to Irwin, 31 July 1930, ibid., f. 104a.

31. Bridgeman journal, volume 2, p. 215. 
That government had failed to produce the reductions in expenditure expected of it, and the derating scheme with which Churchill was strongly identified had been an electoral failure. Above all, his presence at the Treasury, as a committed free trader, was blamed for the lack of initiatives in safeguarding or protection. Conservative voters

complain that such Conservative measures as Extension of Safeguarding, House of Lords Reform, etc. Were stopped by the Conservative Free Traders - Winston was always mentioned.

This blockage had not been removed by the general election, for throughout the next two years Churchill was still considered to be a barrier to imperial preference by its supporters. Thus Churchill was both blamed for the election defeat, and for splitting the party over tariffs in 1930.33 Amery advised Beaverbrook: "if you really want to go for the weakening element there is only one real danger and that is Winston. He, and he alone, wrecked the last Government", while Cunliffe-Lister told Bayford that "he would never again work with Winston as Chancellor - he defeated all Tariff proposals". 34

32. Memo on Bromley by-elction, Campbell to Bowyer, 15 September 1930, Baldwin MSS, volume 51, ff. 13-15.

33. Dixey to Baldwin, 8 september 1930, ibid., volume 165, ff. 104-106; Croft to Beaverbrook, 5 November 1930, Beaverbrook MSS, C101.

34. Amery to Beaverbrook, 13 April 1930, ibid., C5; Bayford diary, 22 March 1931. 
In addition to his anomolous position as a Conservative but a free trader whilst tariff sentiment was once again enjoying a hey-day in the party, Churchill was widely mistrusted for two further reasons. The first of these was his coalitionist past, a sore spot which Churchill exacerbated by pushing the idea of alliance with Lloyd George after the 1929 election. Churchill was incapable of discretion, and was widely thought to be working hand-in-glove with Lloyd George, "obsessed with the idea of another Coalition", even by some who knew him well personally.35 Whatever Churchill's motivation, the concept was hardly practical politics in light of the attitude towards Lloyd George of the backbenchers, and the idea of any such arrangement "is not endearing him to most of our Party".36 The second cause of Churchill's unpopularity was the equally widely held - indeed almost synonymous - view of him as a self-seeking ambitious careerist, out to reach the top of the 'greasy pole' at whatever cost to party, policy, consistency, or loyalty; so that his conduct "continues to inspire doubt and anxiety instead of confidence".37 Thus was Churchill discredited,

35. Lane-Fox to Irwin, 11 December 1929, Halifax MSS, India Office, Eur. C. 152/18/1/328; Beaverbrook to Guest, 22 November 1929, Beaverbrook MSS C27.

36. Cunliffe-Lister to Irwin, 28 December 1929, Halifax MSS, India Office, Eur. C. $152 / 18 / 1 / 344$.

37. N. to Ida Chamberlain, 4 April 1930, NC 18/1/689; R.

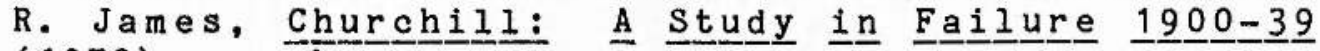
(1970), passim. 
with "very little following" in the House, and "most unpopular in the country", a political giant in decline in 1929, and indeed thought to be nearing the end of his career. 38 on top of this, Churchill performed unsatisfactorily in the Commons in the summer of 1929, and revealed himself to be surprisingly poor at opposition, as well as being frequently absent from the chamber.39 Churchill also suffered from being one of the most prominent targets of the campaign against the continued presence of the '0ld Gang' of party leaders during 1930. Thus, despite having been Chancellor - though not second man in the leadership - for the previous five years, the period of opposition saw Winston Churchill at one of the lowest points of his career, "depressed about his position", looking for something new to bring him out into the limelight. 40

The emergence of the tariff issue as the dominant theme in Conservative party politics from November 1929 to November 1930 was a further problem for Churchill, for it was the one issue which he could not take up with credibility. At the height of the tariff crisis in September 1930 Churchill himself acknowledged that the growth of Beaverbrook's influence was "almost exactly 38. Elibank to Beaverbrook, 18 June 1930, Beaverbrook MSS, C. 126.

39. N. to Ida Chamberlain, 28 July 1930, NC 19/1/663; Bridgeman journal, volume 2, p. 213.

40. Lane-Fox to Irwin, 21 January 1931, Halifax MSS, India office, Eur. C. 152/19/1/211; Lockhart diary, 23 January 1930. 
proportionate to the diminution of mine." 41 The antitariff fight did not attract him, for it cast him in the role of a rebel not only against the leadership - which would not alone have prevented him - but also against the deeply expressed aims and instincts of the party grassroots. It would be a futile gesture, as well as politically suicidal, and Churchill had little desire to go into political wilderness. In fact, Churchill's heart had gone out of the defence of free trade, and, under pressure from the Crusade in his own Essex constituency, ${ }^{42}$ he reluctantly acquiesced in each stage of the road back to a whole-hogging tariff policy, attempting only to retain some appearance of consistency with the young free trader of 1903. Thus in February 1930 he "swallowed the half-way house of the coliseum speech", and remained in the shadow cabinet despite coming to the very verge of quitting over the policy advances of october 1930.43 At the same time as Churchill finally gave up on free trade as a lost cause, he also relinquished his aspirations for an alliance with the Liberals, accepting that coalitionism was dead when in early 1930 Lloyd George aligned his party in support of the Labour administration.

41. Churchill to Beaverbrook, 23 September 1930 , Beaverbrook MSS, C 86 .

42. The Times, 1 July 1930.

43. Tom Jones to E. Jones, 9 February 1930; Whitehall Diary, Churchill to Baldwin, 14 October 1930, not sent, and 16 october 1930, Churchill MSS 2/572, Gilbert, op. cit., pp. 191-194; N. Chamberlain Diary, 19 October 1930, NC 2/22; The Times, 17 July 1930, 24 February 1931. 
Between 1924 and 1930 Churchill had ocoupied a political half-way house between his radical past and his imperial instincts, a position in which the traditional role of the Chancellor as an objector to schemes rather than an initiator had fixed him for the duration of the Baldwin government. It was from 1930 onwards that Churchill began to concentrate his attention on the themes of Britain and the British empire's position in the world. He sought a great imperial issue upon which he could rouse not merely the party, but also the nation, from the perils of weakness and decadence. In this path the greatest influence upon Churchill was his still-intact friendship and alliance with Lord Birkenhead, who brought out the Diehard in him on India in particular, and whose death in 1930 left his friend fixed upon a course of confrontation, yet without a steadying influence. Churchill now developed the Diehard theme that dominated his career through the 1930's:

My idea was that the Conservative Opposition should strongly confront the Labour Government on all great Imperial and National issues, should identify itself with the majesty of Britain ... and should not hesitate to face controversy.

44

The revolt over India, the support of King Edward VIII, and the campaign for rearmament were all of a piece with

44. Churchill Recollections, Churchill MSS 4/113, Gilbert, op. cit., pp. 25-26. 
this strategy. Indeed, the first issue Churchill took up in this light was to oppose the terms of the London Naval Treaty negotiated in the spring of 1930, but this prologue was swiftly overshadowed by the question of India.

Winston Churchill was a curious and complex political character. It is too simple to say that he took up the India question in order to restore his party position, or that he did so only out of concern for the future of the British people. Both factors influenced his actions; first, his declining stature and his unpopularity with the Conservative party and his desire to evade the difficulties of the tariff issue; and second the concerns for the empire. The truth lies in between, and the area of debate concerns how large a part each one played in making up the whole. There is no doubt that, tactically, Churchill had much to gain and little to lose from rebelion - he was expected to be dropped from the next Conservative cabinet. ${ }^{45}$ Against this his only response was to improve his support within the party, and in mid1930 the Diehards, alienated from Baldwin's leadership and in tune with Churchill's instincts, seemed to be natural allies. This does not mean he plotted to oust Baldwin as leader - his position was far too weak for such pretensions. It only meant that the ties which had bound him to the leadershiphad now all fallen away. Equally it

45. Beaverbrook to Churchill, 19 January 1931 , Beaverbrook MSS, C 86 . 
is evident that the prospects of empire, and above all of India, stirred his blood and imagination, and that Churchill, far from being a cunning, patient intriguer, was an impulsive romantic enthusiast, and thus reacted to the imperial peril almost by instinct. Although his imperialism did not find its expression as with other Conservatives through the medium of a tariff preference policy, it was as equally and ardently felt. Furthermore, Churchill had a deep personal sense of history, of mission, and of destiny, and it was this part of his character which identified with the British role in Indian history. It struck a chord in the heart of his being. with the result that any attempts apparentiy to weaken this mission offended against all his instincts. In fact, Churchill had been unhappy over the Montagu-Chelmsford reforms, feeling strongly that self-government for India was an impossible and dangerous delusion. 46 He accepted the rhetoric of the imperial dimension of the national crisis in 1929-1931, and was one of the few first-rank politicians to place it above the domestic dimension in importance. 47 He talked the language of national revival:

after what occurred in Ireland ... and what is being done in Egypt ... I cannot reproach anyone in distant lands for feeling that they have no strong nation behind them, and that conciliation and compromise are almost the only agencies at their disposal. Nevertheless, it is my conviction that upon the

46. P. Addison, "The Political Beliefs of Winston Churchill", Royal Historical Society Transactions, Fifth Series, volume 30, 1980, pp. 40-41.

47. Churchill, speech to Dumbartonshire CA, The Times, 8 September 1930. 
supreme issue of India the British Empire will arise in its old strength, and that ... strength will be given to us in proportion to our need.... I believe that once the evil elements realise that they are in contact with the will-power of Britain, our task will be rendered far less formidable.

Churchill's political stance was clear. All that can be said with regard to motivation is to recognise the genuine element of concern over Indian policy, and the fact that in 1930, as opposed to 1921, Churchill was vulnerable and politically down, with little to lose, unconfined by any claims of collective responsibility or the attractions and preoccupations of high office, but was instead a man searching for a political raison d'etre. His fears over British policy in India thus claimed his full attention and his crusading spirit, coinciding with his self-image as a man of destiny who could save the empire. If there was a tactical reason, tactics alone are not enough to explain completely Churchill's conduct, for he had always beforehand risen through the approval of his leader - Asquith in 1908-1914, Lloyd George in 1917-1922, Baldwin in 1924 - and furthermore his previous experience at rebellion, against Balfour in 1902-1903, was not a

48. Churchill to Irwin, 1 January 1930, Halifax MSS, India Office, Eur. C. 152/19/1/1; speech at Thanet, The Times, 21 August 1930. 
happy augury of success. But, however sincere the impulse, however wholehearted the execution, there were too many sceptics unconvinced by Churchill's Diehard stand to rally round him at once; suspicion of the careerist remained strong. The party's most prominent imperial standard-bearer, Amery, put the point acutely from the public platform:

the fire of [Churchill's] passion over India... was not without its advantage in providing a smokescreen to cover his severance from the party and from the leaders in the really great issues before the country.

The various sectors of Conservative anxiety over India were numerous, but largely incompatible. Churchill proved to be only the most vocal of a spectrum of dissent running across the party as a whole. Amongst the parliamentarians, serious concern was voiced from both leaders and followers. Within the leadership, protests came originally from three previous Conservative holders of the India office: Birkenhead, Peel, and Austen Chamberlain. Of these, the former's attack at the time of the Irwin declaration was the most outspoken, but Birkenhead was even before his early death in 1930 a discredited and declining force. Austen Chamberlain was a more significant figure, and although more temperate in his criticism, was equally pessimistic and negative in outlook. "The Indian situation continues to cause me the

49. The Times, 21 March 1931. 
greatest anxiety ... the viceroy has gone completely off the rails. Heaven help us all.", he wrote in July 1930, as the Round Table conference was about to convene. 50 Ironically, Austen Chamberlain himself was debarred from leading the Conservative delegation to that conference, not because he was too rigid on India, but because of reservations dating from the Irish treaty of 1921, that he would concede too much. Ironically, this veto was applied by Salisbury, who was the most weighty of all those in the leadership who wished to maintain the status quo in India. Indeed, the conflict between his loyalty to the party leader, and his views over India, rather than the publicly announced reason of health, was the cause of Salisbury's resignation as leader in the Lords in 1931.51 Thus the party leadership fell broadly into three camps: a small but politically significant group strongly opposed to Irwin's policy, and restrained only by friendship for Irwin and loyalty to the party and its leader; a middle uncommitted group, the largest of the three, containing figures ranging from the doubt-filled Hailsham and Derby,52 to those such as Cunliffe-Lister and Neville Chamberlain immersed in domestic matters; and the third

50. A. to Hilda Chamberlain, 28 July 1930, AC 5/1/509.

51. Draft resignation letter, June 1931, Salisbury MSS $S(4) \quad 140 / 98-102$.

52. Derby to Croft, 20 February 1931, Croft MSS, CRFT $1 / 10 / \operatorname{De} 8$. 
group of supporters of Irwin's line, such as Davidson, Amery and Hoare, to whose small number was added the compensating weight of Baldwin himself.

There was also considerable anxiety over Indian policy amongst the backbench MPs. This found a forum in the party's own India Committee, despite the fact that this body was aimed in fact as much at containing criticism as expressing it, for its chairman, WardlawMilne, was a loyalist who sought to minimise party divisions by taking a middle path between Irwinism and the Diehards.53 It was from the latter group that the most consistent rebelition came, though the danger could only become serious if this group of some forty to fifty MPs could swing the party centre to their way of thinking. Thus one prominent Diehard, Sir Robert Gower, claimed that "in giving expression to [his] views, he was representing the Conservative Party as a whole". His concept of Conservative policy was simple and clear: "It was the duty of this country to rule India with justice and firmnes", in the light of which Irwin's negotiations with Gandhi were "an act of degeneracy on the part of the British race" which "would mean bloodshed". 54 The logic of the Diehard mind was more fully expressed by another MP, Admiral Beamish:

53. Wardlaw-Milne to Baldwin, 5 February 1931, Baldwin MSS, volume 104, ff. 179-182.

54. Gower's speech at Gillingham CA, AGM, March 1931, Gower MSS. 
I confess to an innate and strong feeling of racial difference and superiority in hearing and dealing with these people .... India left to itself would certainly dissolve into anarchy, bloodshed, and degradation, with its infinitely more varied races and religions. The Indian question to me resolves itself thus: We conquered it, we ruled and developed it, and made wealth out of it and for it. We introduced peace, contentment, progress, and, perhaps, some bad influences. On the whole our rule has been great and beneficient .... We have a right and duty to remain and to rule wisely and firmly. Let us do so, come what may. If only we had some great leader!

Parallel with the Diehard opposition, though not identical with it, were the fears expressed by many figures connected with the Indian services, many of whom, former Indian civil servants and army or police officers now retired and returned to England, formed the backbone of local Conservatism in the outer suburbs of London, the southern rural counties, and the prosperous seaside resort towns. The most prominent figures of this type, the former governors of the Indian provinces, provided a detailed experienced critique upon which was based the Conservative counterattack. Of all these, the most important figure was George Lloyd, former governor of

55. Notes on a meeting between Gandhi and a group of MPs, 23 September 1931, Beamish MSS, $3 / 3$. 
Bengal, and already a Diehard martyr after his recall from the High Commissionership in Egypt by the Labour government in the summer of 1929. Lloyd was not a Diehard as such, and accepted that "one must face realities". His concern centred on the crucial question of safeguards: "My one fear is lest anything should be done which should further weaken the central authority or anything which should undermine the position of the great services".56 Irwin's declaration seemed to him to imperil this crucial need for security, and Lloyd thus began a forceful campaign, though under the umbrella of the party, to build up the forces of resistance. The result, as Dawson noted, was "a real cleavage in the Conservative Party on the subject of India" by March 1931.57

This cleavage was supported by influential groups among the right-of-centre national press, and in certain areas of the party grassroots. Rothermere's Daiㅡyㅗ Mail was soon giving overt priority to the India issue over Empire free trade as "far more vital to the British Empire", and the ㅁaiㅗㅆ Mail had some influence amongst Conservative voters in the home counties.58 More

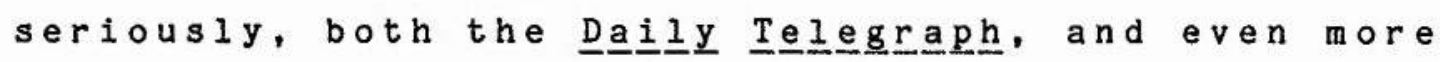
strongly, the M으므믐 으느, wavered towards the Diehard

56. Lloyd to Irwin, 31 July 1929, Halifax MSS, India Office, Eur. C. 152/28/8.

57. Dawson to Irwin, 13 March 1931, Dawson MSS.

58. Rothermere to Beaverbrook, 14 January 1931 , Beaverbrook MSS, C285. 
stance; only The Times could be said to be remotely enthusiastic for Baldwin's line. Equally anxious and equaliy hostile were the two great regional interest groups most economically identified with the Conservative party: the industrial textile interests of Lancashire, and the financial concerns of the City. As a result,

the Conservative feeling has been hardening against Mr. B[aldwin] on the subject of India: Lancashire and London have both helped to influence that feeling for commercial reasons.

Lancashire and the South East were key regions of Conservative support, and the Diehard strategy was focused upon capturing these regions, as the means of stampeding the parliamentary party. 60 In no sector of the party did the India rebels amount to a majority, nor yet were the issues clear upon which such divides might be taken one way or the other by the crucial silent majority in local associations and on the backbenches - the uncommitted moderates. Yet, taken as a whole, the India revolt consisted of a powerful combination of forces: amongst the front benches, the senior backbench MPs, the old India hands, the Conservative press, the constituency

59. Hailey to Irwin, 6 March 1931, Halifax MSS, India Office, Eur. C. 152/19/1/253; Manchester CA, Res., NU Exec, 12 May 1931.

60. Conway Diary, 20 May 1931; Stuart to Cotton Spinners and Manufacturers Association, 7 May 1931, IES MSS Eng. Hist. c.609, f. 20 . 
grassroots, and in the South East and North West more specifically. It was a potentially formidable combination, but it remained to be seen if the India dissidents could overcome their loyalties and their differences to resist successfully the bipartisan line, and to succeed both in retaining their own conviction as well as convincing others that of the crises facing the nation, the imperial dimension took precedence over the domestic dimension.

The alarms over the Irwin declaration had subsided by May 1930 into a period of calm before the expected storms of the publication of the Simon Commission report, and the convening of the Round Table conference. In May Hoare noted of the party's India Committee, "I do not find the members, although most of them are Diehards, are in a state of panic... [but] they are most of them extremely suspicious of the Round Table Conference."61 In this atmosphere the simon Report was looked upon as the potential foundation for a reasoned conservative resistance to dominion status. The report appeared at the end of June 1930 and at first appeared to fulfil this function; in fact, however, the acceptance of the report by Diehard opinion transformed it from a maximum forward position, into a minimal one. Instead of focusing the energies of resistance against the considerable advances 61. Hoare to Irwin, 17 May 1930, Halifax MSS, India Office, Eur. C. 152/19/1/61. 
advocated by the Commissioners, the right-wing seized gratefuliy on the fact that it stopped well short of Irwin's declaration, and thus swallowed it whole.62 This unconscious advance was to leave the Diehards in a poor tactical position when the Round Table conference convened. This weak position was further exacerbated by the involvement of a Conservative party delegation in the conference itself. This was originally conceived as being desirable by that section of the party uneasy or hostile over the sudden quickening of the pace, as being a potential brake on the progress of the conference and upon the government's policy. Party feeling expressed through the backbench India Committee was "overwhelmingly in favour of our insisting upon an inter-party membership of the Conference". Otherwise, if "our people think that they will not be able to exercise a restraining influence with the Conference, they will certainly push matters further". Fears of exclusion had put the party into a mood of "nervous suspicion". 63

The inevitable result of such an involvement, given the careful composition of the conservative delegation, which, while reflecting the range of opinion in the party excluded any out-and-out Diehard, and was dominated by Hoare, was to identify and involve the Conservative party

62. Ormesby-Gore to Irwin, 3 July 1930; Lane-Fox to Irwin, 25 June 1930, ibid., 91a, 87; Unionist India Comittee, Res., The Times, 15 July 1930.

63. Hoare to Irwin, 15 July 1930, Halifax MSS, India Office, Eur. C. 152/19/1/100. 
in the decisions and compromises arrived at by the conference, and thus effectively curtailed its freedom to adopt any position of outright dissent. Hoare, although representative of 'the left of centre', conducted himself deliberately in such a way as to contain the anxieties of the Diehards for as long and as far as possible.64 The policy Hoare backed to ensure that this latter aim need not be incompatible with support for Irwin, was a scheme of federalism, which would give responsible government in the Indian provinces, but not - and here was an essential difference from the Gladstonian Irish Home Rule precedent - at the centre, where the viceroy would retain the allimportant safeguards over 'imperial' matters.65 The merits of this cautious forward policy became apparent soon after the conference discussions began on 17 November 1930. The decision of the most naturally conservative native element, the Indian princely states, to favour a federal constitution for all India, produced a new solution, in which the Conservative party was already implicated. However, by knocking away one of the main props of the Diehard case, this rapid progress not only weakened their position, but also seriously alarmed them into feeling that specific and open resistance was now imperative on the part of British Conservatism due to the

64. Baldwin to Salisbury, 2 August 1930, Salisbury MSS, $S(4) 198 / 29$.

65. J. A. Cross, Sir Samuel Hoare (1977), pp. 132-133. 
collapse, or in their fears the sinister undermining, of Indian conservatism. It was for this reason that dissension in the party was at the same time reduced in extent by the conference, and yet amongst the Diehards increased in intensity to the point of becoming an open rift, and the outbreak of the India revolt was a direct result of the success of the bipartisan policy at the Round Table conference.

Expressions of anxiety, though all far short of any party revolt, had been appearing throughout the second half of 1930. In July Lord Lloyd made his first public speech against the official policy, 66 and not long afterwards a pressure group, the Indian Empire Society, was set up to co-ordinate the campaign, with former Indian governors prominent on its steering committee, and with Sir Louis Stuart as secretary. 67 Churchill converged with this movement during the late summer, giving a critical speech on India on 20 August - symbolically delivered at Carson's home in Thanet. Churchili's reluctance to come to an open break was eroded by his increasing conviction that India was being abandoned due to weakness and appeasement, and by his increasing uncomfortableness with the moves forward on tariff policy in october. On the same day, 14 0otober, that Churchill almost resigned from the shadow cabinet on the tariff question, he also 66. The Times, 10 July 1930.

67. Indian Empire Society Meetings, The Times, 3 July, 5 July, 1930. 
formally joined the Indian Empire Society. The pace of events at the Round Table conference forced on the campaign against further devolution. Thus on 12 December 1930 Churchill was the principal speaker at the first public meeting organised by the Indian Empire Society, where he set the keynote of their campaign by ascribing the present difficulties to a loss of British will to rule, thus leaving his audience to draw the conclusion that the remedy lay as much in assertiveness at Westminster as in New Delhi.68 By the closing of the first stage of the conference on 19 January 1931 , Churchill had established his credentials as the leading critic of Irwinism. 69

The following period was regarded on all sides as being of crucial importance. Whilst the conference was in suspense for consultation of opinion in India and the examination of the proposals produced thus far, and before its undetermined reconvening, the opponents of devolution sought to swing the British parliament to their approach, and thus block further progress. The first stage of this effort came in the House of Commons debate on the conference held on 26 January 1931. Churchill opened with a vigorous and very successful speech, which for the first time attracted the approval of many doubtful backbenchers 68. Churchill's speeches at Waltham Abbey, Thanet, Woodford, and Indian Empire Society meeting at Cannon St. Hotel, London; reported in The Times, $14 \mathrm{July}, 21$ August, 7 November, 12 December 1930 .

69. Churchill, press statement, The Times, 21 January 1931 . 
for a position which was essentially "an indictment of all advance in India".70 But it was Baldwin's response, even more than Churchill's speech, that provoked anxiety in the party over India. Baldwin abandoned the moderate and cautious line in which Hoare had been assiduously coaching him, and spoke instead on the spur of the moment, casting aside his notes and "following his own line of thought". In repudiating Churchill's views and in distancing himself from them, Baldwin veered dangerously to the left, and his speech, though "vigorously cheered by the Socialists", was met with "an ominous silence" from the Conservative benches.71 The immediate result of the debate was Churchill's withdrawal on 27 January from the shadow cabinet over Baldwin's India position - a resignation which began his long spell in the political wilderness during the 1930's. The month of February 1931 thus saw the party, whilst faced with the press lords' campaigns in the by-elections, seriously anxious over its India policy. 72

By coincidence, these problems were resolved at the same period, during March 1931. The worst low point on India came during the period of the East Islington by-

70. House of Commons, Debates, fifth series, volume 247 , cols. 689-703, 744-748, 26 January 1931; Lane-Fox to Irwin, 28 January 1931 , Halifax MSS, India Office, Eur. C. $152 / 19 / 1 / 221$.

71. Ibid.; A. Chamberlain to Ivy Chamberlain, 2 February 1931 , AC $6 / 1 / 785$.

72. Hannon to Beaverbrook, 4 February 1931, Beaverbrook MSS C 155 . 
election fight, when on 9 February Baldwin capped the damage done in the previous debate with a confused and unconvincing address to the party's India Committee. One MP present categorised it as "the poorest speech you could imagine; no one could say after the speech what the Party stood for in Indian affairs".73 The traumas of February were principally caused, however, by the decision of Irwin in India to release Gandhi from detention and to negotiate with him - an action which crystallised the nascent fears of British degeneracy. Baldwin himself acknowledged that these talks had put "the whole of my party ... in a state of great anxiety".74 This revealed itself in the momentary crumbling of support for Irwin in the National Union. Churchill, significantly for the first time ever, attended the meeting of the Central Council fixed for 24 February, and was favourably received by the delegates there. He seconded an Emergency Resolution carried unanimously by the Central Council - but it was a resolution of much apparent bark and little practical bite, aimed clearly at the Socialists, and thus accepted as non-divisive by the meeting. It declared "that the crisis in India is paramount in importance and this Council calls upon the Unionist Party to make a strong

73. Ibid., 9 February 1931.

74. Baldwin to MacDonald, copy, 2 March 1931, Baldwin MSS, volume 104, f. 216; Unionist India Committee, The Times, 17 February 1931. 
stand upon law and order".75 This resolution was to prove the high water mark of Churchillian influence in the party's representative institutions, for never again during the ensuing five years' campaign over India did the Diehards succeed in identifying themselves with the majority. They were subsequently always resisted and defeated, even if only by narrow margins.

In the spring of 1931 the danger was, however, more apparent than real. The tensions were not caused by approval of Churchill, but by the reaction against Baldwin's line in the debate of $26 \mathrm{January.} \mathrm{In} \mathrm{fact,} \mathrm{the}$ party had not veered to the right, but had retained the central position which Baldwin himself seemed to have abandoned. Gwynne calculated "that $85 \%$ of the party is in favour of the Indian policy enunciated by Hoare".76 Thus to ease the position all that was required was for Baldwin to eradicate this unfortunate impression, and for Irwin's tactics to produce some concrete success. When these needs were met, opposition melted away amongst the party centre during and after March 1931. Baldwin's meeting with the India Committee on 9 February had marked the painful beginnings of this process of reassurance, for then he had declared that the party was not committed to any specific plans, and endorsed the approach identified with Hoare. Support for Irwin became a more tenable

75. NU Council, 24 February 1931; The Times, 25 February 1931.

76. Gwynne to Baldwin, 1 February 1931, Gwynne MSS. 
position with the news received on 4 March that his talks with Gandhi had proved successful, and further reassurance was offered by Baldwin in a public speech at Newton Abbot two days later. 77 Before turning to India in this speech, Baldwin dealt with the topic of 'economy' in government spending, and with tariffs, in such a way as to align himself fully with rank and file opinion on these matters. The trilogy of themes was completed by India, on which Baldwin offered both negative and positive reassurances. Negatively he promised that he had no intention of supporting a policy of scuttle, assured his audience that the Simon Report, far from being ignored, had been the basis of every discussion at the Round Table conference, and pointed out that as no detailed constitutional plan for India had been proposed, it was impossible to come to any verdict upon the matter for or against, and that therefore the party was uncommitted in any direction. This he then stiffened by positive reassurance for Conservatives. The rights of British traders with India would be safeguarded, and 1 aw and order in that country upheld. A contentious issue was the claim of the Indian nationalists for an enquiry into the conduct of the Indian police: a demand which, if conceded, not only would outrage Conservative opinion, but which would also raise. grave fears for the morale of the police service. This

77. The Times, 7 March 1931. 
was a mark of the anxiety over the Irwin-Gandhi talks, 78 for it was feared that the viceroy would concede the enquiry. One of the elements in Baldwin's reassertion of his Conservatism-without-reaction at Newton Abbot was his firm repudiation of any such enquiry, whilst he welcomed the talks themselves as the first fruit of the cooperation of moderate men over India. At the close of his speech Baldwin demanded rhetorically:

Have I said enough to dissipate for once and for all the groundless charges that are being made against me on the subject of India?

He had, and the sucoess of his strategy could be gauged from the fact that, without retreating from the spirit of his January declaration, Baldwin was able to present his position in such a manner as to find approval even from the Executive of the Indian Empire Society.79

The third event was perhaps the most crucial: the House of Commons debate on $12 \mathrm{March}$. Debating skill on the floor of the House was the foundation of any politician's political sucoess, and counted almost for everything in the assessment of reputation or the struggle for promotion. Thus Churchill's sucoess in January had "set everyone talking about him and raised his prestige to

78. Unionist India Committee, The Times 1931.

79. IES Exec., Greenway to Baldwin, 9 March 1931, Baldwin MSS, volume 104, ff. 230-232. 
a higher level", 80 while Baldwin's ineffectiveness was a telling factor in the party crisis of February-March 1931. The debate of 12 March decisively reversed this position, for it was Baldwin who produced an oratorial triumph, elevating the discussion to a moral level yet also providing a rare exhibition of knock-about debating skill. The target for this was Churchill, who, much discomfited by Baldwin's quotation from his pro-devolution speeches of 1920, in his turn produced a poor speech, and "fell very flat and frankly at the end was boring the House". 81 Churchill persistently overstated his case, presenting his opponents' approach as being immediately, rather than in eventual implication, a policy of pure scuttle, and thus gave Baldwin the tactical room to manoeuvre in which he could both repudiate churchill and yet at the same time strike a sufficiently Conservative note to carry the bulk of his party with him. This was the crucial difference between the debate of 26 January on the one hand, and the Newton Abbot speech and the debate of 12 March on the other. In the former, Churchill's successful speech had left Baldwin isolated on the left of his party, sounding a note which left most Conservatives unmoved. Now the position was reversed, and it was Churchill who was left

80. N. to Hilda Chamberlain, 31 January 1931, NC $18 / 1 / 724$.

81. Lane-Fox to Irwin, 12 March 1931, Halifax MSS, India Office, Eur. C. 152/19/1/266; Dawson to Irwin, 13 March 1931; The Times, 13 March 1931; House of Commons, Debates, fifth series, volume 249 , cols. $1417-1468,12 \mathrm{March} 1931$. 
isolated on the right - an isolation from which he was unable to escape.

The strategy of the India dissidents in the Conservative party concentrated on resistance to further progress during the life of the Labour government, for that was the period during which they feared that the pass might be sold. Their unquestioned belief in the return of a Conservative government in the next election a victory along the lines of 1924 being anticipated - was supported by the incorrect assumption that a Conservative majority in the House would be by definition extremely cautious on the question of India, and would emphasise the matter of safeguards more and the proposal of dominion status less, than the prevailing bipartisan approach. 82 In this they were to some extent correct, for the line that was followed from 1931 onwards bore the appearance of the moderate policy of Hoare in the letter, but in the spirit they were fataliy mistaken. The error was the product of having underestimated, despite the speech of 12 March 1931, the genuine commitment of the party leader to the policy he was following, as a result of confusing it with his temporary need to keep in harmony with the Liberal and Labour attitudes in order to preserve British political unity. This was matched by two further underestimations: the first was the extent to which Baldwin could carry the centre of the party with him; and 82. Churchill at Thanet, The Times, 21 August 1930; at Cannon St. Hotel, The Times, 12 December 1930. 
the second was the considerable augmentation of the left and centre of the party proportionately at the expense of the right wing in the composition of the parliamentary party after the recovery of the marginal seats lost in 1929 that would be an essential element of any future electoral victory.

The period from the Irwin declaration in November 1929 to the end of the first Round Table conference in January 1931 formed the prelude to the India revolt within the Conservative party. The question was considered acute by the dissidents from the end of the conference on 19 January until the moment of its unfixed future reconvening. It was in this gap that the rebels sought to mobilise their forces. The Diehard manifesto and strategy were set out clearly in Churchill's press release on the day after the conference's adjournment:

It is not yet too late .... The key to Indian government is still in our hands .... Matters cannot stop where they are. In a few months fresh conferences and negotiations will begin. It is the duty of those who care for the endurance of the British Empire and who believe that that supreme fact is intimately connected with our ability to discharge our mission in India, to rouse and organise public opinion in the short breathing space now accorded us.

83. Churchill, press release, The Times, 21 January 1931. 
Thus the critical period for the united front on India was from the end of January 1931 onwards. After the setback of the debate of $12 \mathrm{March}$, the dissidents continued the struggle despite the odds against them, for they were convinced that they could strike a chord in the very heart of Conservatism. At the Albert Hall on 18 March Churchill redefined their aims:

they had against them at the moment the official machinery of all three great parties in the state. Their fight would be a hard one, but, win or lose, they must do their duty.... [The conference would reconvene, but] by that time we shall be ready too. We shall not be taken by surprise, as we were at the [first] Round Table conference. We have behind us the growing strength of Conservative opinion. We have the sure prospect at no great distance of a Conservative victory, and by the time Mr. Gandhi has arrived here to receive the surrender of the Indian Empire the Conservative Party will not be so ready to have its name taken in vain.

In fact, however, their campaign failed to make an impact during these decisive months.

The reasons for this were partly structural. The position of the rebels was weak in a number of crucial areas, the first of which was in the matter of leadership. The Diehards themselves by their very nature tended to be a collection of long-serving but largely inarticulate backbenchers, of no ministerial experience and with little debating skill or platform oratory; hence their need to look outside their own immediate ranks for sympathetic leadership from more prominent figures in the party 84. The Times, 19 March 1931. 
leaders and allies such as they had found in 1921-22, but were not to find in 1931-35. Churchill was not, at least for some time, an acceptable leader. His past political record, his suspected vaunting ambition, and his previous involvement with both Irish and Indian devolution rendered him a highly suspect figure to much of the Conservative party, with whom "he does not carry conviction... he has disclosed too many shifting phases to expect to be regarded as immovable now". 85 However, the other potential leaders for the Diehard stance on India were all ultimately unwiling to head a revolt against the leader. Hailsham and Austen Chamberlain swallowed their doubts by attempting to wield more influence within the party elite than without, whilst salisbury, who resigned from the leadership of the Lords mainly over India, allowed his departure to cause no ripples on grounds of party and personal loyalty. The Diehards were thus left largely leaderless, and proved unable either to appeal to the party centre - which tended to see the rebels, rather than the leader, as the cause of faction - or even to unite with other sections of Conservatism in revolt against Baldwin. The India rebels and the Crusaders did not coordinate their strategies, and indeed Beaverbrook was at best ambivalent towards Churchill's views on India, whilst actively resentful of the way in which Rothermere kicked over the traces and ran India as the principal issue at 85. Beaverbrook to Borden, 7 January 1931, Beaverbrook MSS. 
St. George's. Tariff reformers in general did not find the free trader Churchill a likely comrade-in-arms. The two campaigns were also out of synchronisation. The protectionist battle reached a high point of seriousness for Baldwin between June and October 1930 and was largely appeased by the concessions made in the later month. India, on the other hand, had flared up briefly as an issue in November 1929, was then relatively quiescent until December 1930 and only became a serious matter after the closing of the Conference on 19 January. It was true that this last stage coincided with Beaverbrook's forays at East Islington in February, and the loss of morale in the leadership of early March 1931; but, as has been demonstrated in Chapter 5, these challenges lacked the support of the grassroots, and were the self-defeating rampages of a political rogue elephant.

Thus the India Diehards were left to campaign alone, and, taking their political cue from the Daily Mail, made a series of tactical blunders throughout their rebelition. Even at the nadir of his Indian policy in February 1931 , Baldwin's position had considerable latent strengths, the most important of which was the prestige and power of his position as party leader, and the appeal for trust and for loyalty which he could exploit. He could count on the hesitant support of the party centre, whom Churchill noted "are all afraid of being labelled disloyal", 86 and the

86. Churchill to Rothermere, 3 February 1931, Churchill MSS 2/180, Gilbert, op. cit., p. 259. 
positive and vocal support of another group, not all associated with the left of the party, who went some way to balance the Diehards. Prominent amongst these supporters were Amery, Geoffrey Dawson (the editor of The Tímess), Oliver Stanley, a rising young figure and one of the four delegates to the Round Table sessions, the Astors, a number of backbenchers such as spender-clay, Davidson, and Lane-Fox, and - rather more cautiously Hoare. 87

Most significant of all, however, was the fact that the party grassroots, with the rarest of exceptions, was not yet disturbed over India. The low level of rank and file concern in the local Associations was in marked contrast to the energy expended on the question of empire free trade. Only one resolution critical of party policy was forwarded to the National Union, from the MidBedfordshire Association; two others more or less enthusiastically supported Baldwin's Newton Abbot line and affirmed the necessity of securing adequate safeguards.88 Amongst the sample of the surviving local Association minute books the quiescence over India is even more noticeable - as are the finer shades of opinion. The area of concern was limited to the matter of constitutional safeguards, and felt more acutely in

87. Baldwin to Gwynne, 3 February 1931, Gwynne MSS 115; Lady Astor to Subbarayan, 9 April 1931, Astor MSS $1416 / 1 / 1 / 1011$.

88. Mid-Beds. CA, Res.; Manchester CA, Res.; Sussex Prov. Div. Res., NU Exec., 12 May 1931. 
Lancashire due to the domestic difficulties of the cotton trade, from possible future Indian protectionism.89 In two Associations Diehard opinion over India was given expression to,but exposed as a minority viewpoint, although both were strongly Conservative safe southern constituencies: at Chichester a Diehard resolution was voted down by forty-two votes to twenty in the Association Executive in favour of a resolution supporting the Irwinite policy, and at Wells a hostile resolution on India could not find a seconder. 90 Elsewhere the topic was either simply not discussed at all, or the comments were pro-Baldwin and aroused no opposition. The state of party opinion over India in the aftermath of the events of March 1931 could be summed up by the balance of forces exposed at Chichester and Wells, and the comments of the local MP at the Reigate Association annul gathering:

it was not possible today to hold India by force, but only through comradeship. He had the greatest of faith in Lord Irwin, who, he reminded them, was appointed by a Conservative Government.

or those echoed at Rushcliffe, that India "would never be brought into the cauldron of party politics".92 This was 89. Clitheroe CA, Exec., 15 April 1931; NU Council, 30 June 1931.

90. Chichester CA, Exec., 13 April 1931; Wells CA, Exec., 17 March 1931.

91. Reigate CA, AGM, 18 Márch 1931.

92. Rushcliffe CA, AGM, 14 March 1931. 
reflected at the meeting of the parliamentary India Committee after the Commons debate of $12 \mathrm{March}$, where of the one hundred MPs present, only five irreconcilable Diehards voted against a resolution approving Baldwin's line. 93

Despite the considerable unease after his speech in the debate of 26 January 1931, Baldwin's and Irwin's policy held the line. One reason for this was the fact that the discussion during 1929-31, though it in reality settled firmly a number of crucial principles on party policy over India, nonetheless was not concerned with any specific legislation. The Diehards had nothing of detail or substance to chip away at; no bill was before parliament, and policy still appeared to be as yet unformed, and thus the question not yet at the forefront of politics for many people. In fact the tone and cast of the debate had enormous implications for the future, for debate had become quantitative over the safeguards 94 rather than a question a yea or nay on the principle at issue - and from this advance there could be no retreat, if only because of the importance attached to honouring Britain's word and pledges. The positive supports for the Baldwin/Irwin line should not be underestimated. Over and above the appeal of keeping India out of party politics, was the fact that the princes themselves had opted for federalism, making that policy both more attractive and 93. Unionist India Committee, The Times, 17 March 1931. 94. Letter from IES, The Times, 7 January 1931. 
more respectable.95 Support for Irwin himself was a far from negligible factor. This was partly due to his personal standing and character, 96 and even more to the general Conservative tendency to accept without question the wisdom of the man on the spot: "99 times out of 100 he is right".97 This factor was further reinforced by the support for Irwin's policy expressed by the currently serving governors of the Indian provinces, many of whom such as George Stanley, Goschen, Sykes and Jackson, had been prominent in the middle ranks of the parliamentary party before accepting positions in India. Above all, by placing the emphasis at Newton Abbot on 6 March on the necessity for safeguards, Baldwin first aligned himself with majority sentiment in his party, and then swept it forward with his oration in the Commons on $12 \mathrm{March}$. The two pronouncements together - not either one singly - are the true expression of Conservative policy over India in the early 1930's, balancing safeguards with the spirit of the Round Table conference, and acknowledging "that the Empire, if it is anything, is a living organism... in a constant process of evolution." 98

Not only did these structural themes and forces militate against the success of the Diehard revolt over 95. Bayford Diary, 22 March 1931.

96. Headlam Diary, 10 May 1930.

97. Stonehaven to Irwin, $17 \mathrm{March} 1931$, Halifax MSS, India office, Eur. C. 1522/19/1/271.

98. Baldwin, House of Commons Debates, fifth series, volume 249, col. 1418, 12 March 1931. 
India, for political factors also undermined their efforts to maintain the primacy of the imperial dimension in the rhetoric of concern over national decline. Distractions from the question of India abounded, and due to the relative calm in that country after the Irwin-Gandhi pact, it slipped from the forefront of the public mind. The first distraction from the Diehards' campaign was, ironically, the party's differences with the press lords in February and March 1931, and this was compounded by the fact that in the process of resisting the loss of confidence in his leadership Baldwin reasserted himself with "one of the greatest efforts of his parliamentary career" in the Commons debate of 12 March.99, This served the dual function of triumphing over both the challenges against him: over the despair of his colleagues by the success of the speech, and over the India dissidents by both oratory and content. Paradoxically, the restoration of order in Conservative politics in April 1931 did not provide any opportunity for the India agitation to take the centre of the stage. For the emphasis now was placed fairly and squarely on the need to get the Labour government out for reasons of domestic policy - and the cry for 'economy' held the ring from April to August 1931.100 Not only did this concern push both the tariff question (though the latter was now accepted party policy) 99. The Times, 13 March 1931; see Chapter 5.

100. It was placed first by Baldwin at Newton Abbot, for example; The Times, 7 March 1931. 
and the India question into the background, it also militated against any toleration of further intra-party faction. To some extent the long struggle over tariffs and the Empire Crusade had worn down party patience, but of more significance was the accepted priority of the need to restore 'sound' budgetary and taxation policy; thus the forces for sound government at home were not to be weakened by disputes of degree over sound government for India, or disagreements over the details of agricultural policy. These latter were all seen, in the last resort, as sectional interests, whilst the economy question was a national peril. The shock waves of the East Islington result had as many implications for dissidence over India as over protection or leadership.

The national 'peril' perceived in the spring and summer of 1931 produced logically the realignment of August 1931. By the end of that process, after the general election of October 1931 the pattern of policy over India was set. The rebels had missed their opportunity to mould party policy against the spirit of the Round Table conference whilst it was still in a malleable form. All that was left to them now, isolated against the massed ranks of the new MPs of the National Government, was to turn to the last weapon in their locker. This unpromising last resort was to campaign from 1931 to 1935 to attempt to capture the party grassroots via the National Union, turning it into the engine that would force the Conservative MPs to break with their 
leader's policy.101 This was a herculean task indeed, swimming against the tide of ingrained party loyalties and traditions, and requiring ultimately that the normally deferential National Union adopt a role which it had never before achieved. As the experience of Beaverbrook's similar campaign of 1929-31 to capture the local Associations demonstrated, such a project was difficult enough in times when the party was defeated and restless under ineffective leadership. Against a party in office, successful beyond precedent at the polls, and without the demoralisation that results from weak leadership, it was to prove impossible. The large though minority votes achieved by the Diehards in the National Union Council and conferences of 1933-1935 should not obscure these realities. There would always be, as there was even at the end of the parliament of 1929-31, a substantial and vocal element of Diehardism in the safer southern seats. 102 But it was always a minority, and even when Lancashire grew cautious over Indian trade, the fact remained that it was beyond the power of the rebels to obtain a majority in the party, contrary to the appeals of the leader. It was quite clear that, given the domestic peril, the party in the final analysis would not smash up the National Government over India.

101. Knox to Sydenham, 24 June 1931, IES MSS, Eng. Hist. C. 620, f. 59 .

102. Report of Irwin's meting with the Unionist India Committee, in Hannon to Beaverbrook, 23 June 1931, Hannon MSS $18 / 3$. 
In this sense it is valid to argue that the failure of the right wing to defeat Baldwin over India in the spring of 1931 was the decisive moment in the settlement of the future of India so far as British politics were concerned. Baldwin was never again to be in such a vulnerable position, and the verdict of March 1931 settled the issue against the rebels, despite all their efforts during the subsequent four years to appeal to a higher court. In settling the matter in this way, the primacy of the domestic dimension over the imperial in practice - if not in rhetoric - was established. It might logically be accepted that the acceptance of this primacy, albeit unconsciously, was the first stage of the gradual accommodation of Conservatism to the eventual position under Macmillan thirty years later in which it could accept painlessly the dissolution of the old-style empire by its transformation into a modern association of selfgoverning units. Churchill and the Diehards were aptly categorised as imperialists of Queen Victoria's first jubilee, but as Irwin acknowledged in March, 1931 "that conception of Imperialism is finished". 103 of course, other factors, principal amongst which was the exhaustion

103. Irwin to Davidson, 31 March 1931, Halifax MSS, India Office, Eur. C. 152/19/2/306. Another example of the primacy of the domestic dimension was the financial restraints on East African development: $N$. Chamberlain to Walker, 15 December 1930, Walker MSS, Rhodes House library, AFR. S., $717 / 4 / 4$, in Dean thesis, pp. 341-342. 
caused by the second world war, were more immediate causes of decolonisation. But in the search for its roots, the choice of political priorities made by the ostensible party of empire between November 1929 and March 1931 must be a crucial landmark. 


\section{CHAPTER 7}

\section{National Peril: (ii) The Domestic Dimension}

The Conservative party had. traditionally been associated with the 1 anded, or agricultural, interest, a relationship perpetuated into the inter-war period. There was a close relationship with the National Farmers Union, and dependence for the bedrock of electoral support upon the rural county divisions. However, the character and concerns of the party were changing under the dual impact of the decline of the Liberal party and the rise of a Socialist party. The influx of business and financial interests - a tendency evident well before the first world war - was now tipping the balance within the House of Commons, and amongst the front bench leaders. The primacy of the business mentality had given concern for some time, being a particular source of comment during the post-war coalition parliament, but in reality neither group then had the upper hand. Indeed, they had not previously been opposed, for the appeal of a protectionist policy was potentially as attractive to agriculture as to industry. For both also, the primacy of anti-Socialism assured not only unity, but active support, for the Conservative party during the elections of the early 1920's, and this went some way to explain both the polarisation of antiSocialists behind Baldwin and the consequent decline of the Liberal right-of-centre. The period of tranquillity provided by Baldwin's 1924-1929 government, however, had significantly reduced these fears and tensions, a process 
in which the defeat of the General Strike in 1926 had played a large part. By the general election of 1929 both 'conservative' interest groups had reasons to feel dissatisfied with, or apathetic towards, the conservative party, an apathy which had contributed to its defeat.

Initially, the running was made by the vocal dissatisfaction of the agricultural interest after the 1929 election. 1 Indeed, Beaverbrook's Empire Crusade campaign was as much about domestic agriculture as imperial trade. His campaign had begun as an appeal to the farmers, and it was from those areas that he initially received grassroots support. ${ }^{2}$ The National Farmers Union itself came close to breaking its informal but extensive ties to the party in resentment at the absence of a suitable agricultural policy, and its alienation did not produce far-reaching consequences in the county divisions only because of the internal and tactical divisions within the Union itself, as it oscillated between affiliation to the Crusade and an ostensible 'above party' position. However, the frequently voiced suggestion within its predominantly conservative ranks to set up a separate agricultural party was a clear sign of the seriousness of

1. Eastern Area, Exec., 10 October 1929.

2. Beaverbrook to Elibank, 20 November 1929, Beaverbrook MSS, C126; to Chaplin, 26 November 1929, ibid., B95; National Farmers Union, Parliamentary Committee, 15 July 1930, 16 September 1930. 
the loss of faith and confidence in this crucial element of Conservativism. 3

Whilst keeping one eye on the electoral barometer of public opinion, Baldwin moved carefully and cautiously during 1930 to appease the agriculturalists. The truce With the Crusade in March 1930 removed much of the direct pressure, and in the period before that truce collapsed Baldwin went some distance to present an agricultural programme by his speech of 9 June 1930 at Glemham Park. 4 This polioy was designed to stop short of complete agricultural protection with its accompanying dear food connotations. The second stage of advance came with the policy brought forward in October 1930 which based itself not on tariffs, but on the quota system. This latter move provided the facade on the edifice of a popular Conservative agricultural policy. It had been the product of negotiations throughout the summer months with the NFU, conducted by Lord Wolmer, and the crucial point was that the quota system was favoured by the NFU leaders. 5 The final stage in the conciliation of the farmers came in the winter of 1931, when their agitation against the 'dumping'

3. National Farmers Union, Parliamentary Committee, 1929-1931, passim., especially 17 December 1929, 17 June 1930, 14 October 1930, 17 February 1931. It can hardly be coincidence that such sentiments surfaced at the same points as the peaks of internal dissatisfaction within the Conservative party.

4. See chapter 3 .

5. For negotiations with the NFU, June 1930 - February 1931 , see copies in Baldwin MSS, volume 31, ff. 236346; for NFU and quotas, Wolmer to Ball, 2 January 1931, Selborne MSS, Eng. Hist., c. 998, ff. 3-5. 
of ruinously cheap subsidised foodstuffs from the continent were met by the party's adoption in that period of the now-popular proposal for an 'Emergency Tariff' which would be imposed as soon as it returned to office as a holding operation. 6

However, this process of appeasement could not hide the fact that by the end of 1930 the concerns of the agricultural interest were beginning to lose pride of place. Calls for further advances - under the code word of seeking further 'definition' of policy - were seen as potentially divisive and no longer commanded the same degree of rank and file support.7 By the summer of 1931 the agricultural issue had been pushed into the background by the concerns of industry and finance with other aspects of economic affairs - and the concerns of the latter groups received priority even where they cut across the former's. Thus Addison's popular Agricultural Bill was sacrificed at the altar of reducing government expenditure. 8 The shift of concern away from agriculture was evident in mid-summer 1931, when not one Conservative front bencher bothered to speak during a vote of censure debate on agricultural affairs on $20 \mathrm{July}$, and in all the speeches and statements of the new Conservative programme

6. Amery to Beaverbrook, 19 Maŕch 1931, Beaverbrook MSS, c6.

7. NU Council, 25 November 1930.

8. House of Commons Debates, volume 250, col.944-951, 31 March 1931. 
agriculture came in as the last-mentioned aspect, not the foremost, during $1931 .^{9}$

This attitude was a reflection of the maturing changes in the composition of the party vis $\underline{\text { a }}$ i $\underline{\text { s }}$ the prewar period with the growing strength of the business element. The landed group in 1929 comprised only fifteen per cent of the MPs, whilst the business group were more than double that size, and, taken together with the professional men - mainly lawyers linked more to finance and urban life than to land and rural concerns - made up more than two-thirds of the parliamentary party. The links with the older atmosphere of the landed squirearchical party of the late-Victorian era. were passing; in 1930 only forty Conservative MPs had sat before 1914, and many of those forty represented not the old sectors but had been themselves harbingers of the new business ethos. ${ }^{10}$ This development was further matched by the increasing role of business in providing the party funds, both locally and nationally. 11 That the business group did not dominate the party in a more visible sense was due to the pre-eminence in the public eye of the career politicians, and to the corresponding

9. Ibid., volume 255, col. 1141, 20 July 1931; N. Chamberlain's speech in London, The Times, 27 February 1931, was typical of the low status and secondary interest of agriculture.

10. J. M. MoEwen, thesis, pp. 304-307.

11. J. A. Ramsden, thesis, pp. 338-347. 
inarticulateness of the business sector, as well as the poor reputation of that part of it habitually referred to as the 'Forty Thieves'. This had contributed in 1930 to the impression that the business block was being ignored and flouted, and that as a result it was thought to be a motive force behind the right-wing revolt. ${ }^{12}$ In reality this was far from the case. Certainly by the 1929 election much of the enthusiasm for the conservative government evident in 1924 amongst business circles had evaporated. Baldwin had refused to act as the representative of any sectional interest, and churchill's budgets had also not provided the desired reductions in expenditure and taxation. 13 The result of this was both a mood of disinterest in the City, and the favourable reception, even feting, of Labour figures in 1929, when MacDonald was presented with the freedom of the City. However, the alienation from Conservatism was only superficial, and the product of apathy alone; the role of the business world during the Crusade campaign was for the most part of 1930 one of neutrality. Cunliffe-0wen reported the mood of the City in May to be "one of sulks" and that "there is not much chance of getting money in the City for political funds of any sort or kind". 14 However,

12. Remer to Taylor, copy, 31 October 1930, Baldwin MSS, volume 31 , ff. 185-187.

13. Swire to Bowyer, 14 August 1931, ibid, volume 117 , ff. $155-156$.

14. Cunliffe-0wen to Beaverbrook, 30 May 1930 , Beaverbrook MSS, C107. 
when this indifference began to evaporate during the second half of 1930 , business in politics identified with the party leadership, quashing dissent and rebellion, in order to secure the party as a united force behind the banner of its own economic interests.

This return to political involvement was largely the product of factors external to Conservative politics. The first stage began with the hostility of the coal owners to the government's Coal Bill of late 1929, although the party was always slightly reluctant to be tied to the chariot wheels of that particular interest group. ${ }^{15}$ More significant were the actions of the Labour administration during 1930; the proposal at the electoral reform conference to remove the business franchise and plural voting, and of more immediate consequence, the addition of six pence to the income tax in the 1930 budget and the dismantling of the safeguarding duties which had afforded certain industries a limited form of protiection from overseas competition. ${ }^{16}$ But, above all, it was as a consequence of the economic recession that the business world returned with a renewed sense of urgency and concern to matters of domestic politics during the winter of 1930 and the spring of 1931.17 As a consequence of the slump

15. Correspondence with Coal owners Association, November-December 1929, Steel-Maitland MSS, SROGD $193 / 437 /$ ff. $7-12$, $92-98$.

16. N. to Ida Chamberlain, 20 April 1939, NC 18/1/692.

17. A. to Hilda Chamberlain, 21 March 1931, AC 5/1/535. 
throughout 1930 there had been a strong and continuously growing current of opinion in the direction of abandonment of free trade in favour of protection, so that the policy was for the first time becoming genuinely a popular asset and a rallying cry amongst supporters. The Bankers' Manifesto of July 1930 and the Associated Chambers of Commerce in August 1930 came out for extensive safeguarding, whilst in October 1930 the Federation of British Industries conducted an internal referendum which produced a ninety-six per cent vote for protection - even the Trades Union Congress were making favourable noises by the winter of 1930.18

By January 1931 the dominant concern in the business sector was not, however, so much with protection, as with the belief that the principal cause of the slump and the main drag on any recovery of industry was the level of taxation and of local government rates. This had been the concern of finance and industry for many years, and had been the principal inspiration behind the derating policy of 1928-1929, but, as the central tenet of financial orthodoxy, it inevitably returned to the forefront of the political stage with the onset of the economic crisis being combined with a Labour government committed on principle to a high-level expenditure on the social services. These services had even in the most prosperous of times been considered in the Conservative frame of mind

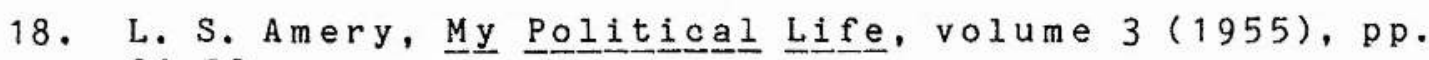
31-32. 
to be items carried on the luxuries' ledger, and thus the first target for reducing the load in times of crisis. This attitude determined the decision to oppose, and to destroy in the House of Lords, the government's Education Bill in the spring of 1931; the bill was above all else, "financially reckless". 19 The real problem, however, was the Unemployment Fund, for as a result of the slump the number of the workforce needing support was overstraining the Fund, and was causing the financial community grave anxiety over the repeated borrowing for the: Fund beyond its means, which produced fears of an unbalanced budget and a large deficit by the end of 1931 - in other words, in the economic orthodoxy of the day, national bankruptcy. Faced with this overriding peril, the business sector raised the twin standard of reduction of direct taxation, and 'economy' in government expenditure, as the only sure path to the recovery of business confidence and investment - and therefore eventually to the reduction of unemployment and the return of prosperity. 20 In this protection, especially in the form of the emergency tariff on imports, could play its part, but it was significant that for the remedy for massive unemployment the issue admitted by all parties in the inter-war period

19. Memo on Education Bill, Salisbury MSS, S(4) 139/1; Hailsham to Beaverbrook, 23 February 1930 , Beaverbrook MSS C180. Chamberlain to Hilton Young, 8 November 1930, Kennet MSS $16 / 4$.

20. Duke of Buccleuch, Governor of Royal Bank of Scotland, address at Edinburgh, 26 November 1930 Gleanings and Memoranda, January 1931, pp. 19-20. 
to be the most significant social problem - the Conservative party was perceptibly turning away from its 1923 platform that protection alone would suffice, to a position by mid-summer 1931 where economy was placed even above tariffs in the Conservative economic remedy. For the party was not slow to respond to the mood of the financial and industrial sectors, and already in september 1930 Neville Chamberlain had come out for the reduction of direct taxation, whilst as early as February 1930 one City financier and Conservative candidate had declared that "the intolerable burden of taxation on Industry must be removed by ruthless economy". 21 This, the banner of the City, was to become the foremost item in the Conservative party programme by the summer of 1931, and came to dominate Conservative politics.

The campaign for economy had in various guises been an intermittent theme in Conservative politics for many years. It had been frequently used by dissidents of the Diehard wing as an issue upon which to arouse wider support amongst Conservatives generally - such as during the Anti-Waste campaign of 1920-1922 - precisely because the economy cry had an appeal far wider than any sectional Diehard complaint could engender. For three reasons the economy campaign was one which the leadership moved rapidly to take up and make its own: first, as a

21. N. to Ida Chamberlain, 21 September 1930 , NC $18 / 1 / 742$; Hulton to Beaverbrook, 23 February 1930, Beaverbrook MSS C180. Memorandum, 'Causes of the Slump', prepared for the Conservaticve party by Hilton Young, 1931, Kennet MSS $81 / 1$. 
result of their genuine community of interest and of economic thought with the circles of finance and industry; second, because the economy cry was too dangerously popular in the party to be ignored by the leadership; and third because, even more than tariffs, the economy issue could unite all sections of the party behind a potentially popular - in Conservative circles, that is - policy. Many of the Conservatives who flirted with the crusade in the early. part of 1930 had done so not just because it offered a vigorous lead on protection not provided by Baldwin, but also because whilst Baldwin had disappointed hopes for economy in his previous government, they had hopes, which Rothermere himself expressed, of turning Beaverbrook's movement into a campaign for other Diehard causes, above all for economy. 22 Thus, as the anxiety over taxation and government expenditure came to the forefront during 1930 , the party leaders responded with a rapidity and commitment which was in revealing contrast totheir attitude towards the advocates of protection in the previous year. In the press release which had announced the policy advance in response to Bennett at the Imperial Conference in October 1930 it was noticeable that Neville Chamberlain, when drafting the leaders's statement "placed economy first, then the emergency tariff, then repeated the pledges already given to agriculture... then came to Empire

22. Gisborough to Salisbury, 25 February 1930, Salisbury MSS, S(4) 133/175. 
Trade". 23 By December 1930 Baldwin was echoing the other face of economy in his public speeches, declaring at Glasgow on 12 December, "It is of the greatest importance that we should be able to reduce taxation". 24

The main impact of any reductions must come, it was clear, in the spending on the social services. This would mean not only salary reductions for government employees and the cutting of capital expenditure on building projects, of roads, schools, hospitals, and so on; it would above all mean a reduction in both the level of the unemployment dole, and of the number of recipients entitled to it, for it was evident that it was the financing of this outlay that threatened more than anything else to unbalance the budget. 25 It is revealing that such a programme was not considered by Conservative strategists to be an electoral liability, in a similar fashion to their pragmatic fears over food taxes. This was only partiy due to the fact that a reduction of the unemployment relief would only affect a minority section of the working class, whereas food taxes would affect them all. It was more the product of three other factors. First, there was a case that after a decade of slight deflation, the dole was now worth more than it should be. This was allied to the second factor, which was the

23. N. Chamberlain diary, 19 October 1930, NC $2 / 22$.

24. The Times, 13 December 1930.

25. Conservative Research Department Memoranda on Unemployment Insurance, CRD/6, CRD/9, in AC $49 / 1 / 6$. 
concurrent press campaign exposing the abuses and occasional scandals in the dole system, which was producing an indignant response from grassroots Conservatism. 26 Third, and perhaps more important, was the widely shared belief that no section of society could be immune to the wage reductions and general economies of the past years. This was allied to the economic orthodoxy of the day, accepted instinctively on the level of 'housewife economics', or as commonsense, by both the middle and much of the working class, that their prosperity was bound up with the national prosperity, and that anything which undermined that must be avoided. All this was revealed by the anxiety over the danger of a budget deficit that the country, like any individual family, could not live beyond its means. 27

Economies were thus not seen in class terms, and though there was some Conservative anxiety on this question during the crisis of August 1931 when the scale of the economies needed became suddenly apparent, there was little such anxiety on the topic before that crisis period. 28 The principal Conservative rallying cry to avoid the potential class antagonisms that dole and wage cuts might produce, was the widely accepted commitment to 'equality of sacrifice', in which all parts of the nation, 26. R. Skidelsky, op. cit. p. 232; Hemel Hempstead CA, Exec., 25 July 1931.

27. Horne at Hawick, The Times, 21 February 1931; Neville Chamberlain at Birmingham, The Times, 9 January 1931.

28. N. to Hilda Chamberlain, 20 June 1931, NC $1 / 1 / 744$. 
it was claimed, would do their patriotic duty. It was another facet of the economic crisis, and of the financial and national crisis of August 1931 that it was looked upon as both a national peril and also, with many parallels being drawn with the experience of the first world war, as a cause for national solidarity. 29 In any such atmosphere the Conservatives, with their self-image and public pose as the patriotic party, were bound to be the beneficiaries of the rally of national sentiment - even to be in danger of being swept away by it.

The economy issue had thus been present in the background of the political contests of 1930 over imperial preference. It became the foremost issue after the effective settlement of the latter question by the policy advances of october 1930 and became acute during the winter of 1930 and spring of 1931, for "the position is considerably worse than it was last year, and last year it was bad enough ".30 The reaction to the Labour government's "squandermania" became acute in the first quarter of 1931, and even in the dark days of the internal party crisis of February 1931 Neville Chamberlain looked hopefully to the effect of "the policy of spending ... in the money market". 31 In January a Conservative MP with City connections urged that:

29. Hailsham at Exeter, The Times, 21 March 1931.

30. House of Commons Debates, fifth series, volume 250 , col. $944,31 \mathrm{March} 1931$.

31. N. to Hilda Chamberlain, 14 February 1931, NC $18 / 1 / 726$. 
feeling is getting so strong in the country that we must not be afraid to go all out for real economy rationing departments and tackling the dole

In short, that the party should "put Economy first with a capital E". 32 This atmosphere was reflected in the trend of speeches made by leading front benchers from January, 1931 onwards. In that month Neville Chamberlain declared that "their first duty must be to devote themselves to the task of cutting down national expenditure and calling a halt to the extension of social services", a theme echoed by Baldwin a week later, and simultaneously taken up by other prominent figures.33 Significantly, when making his crucial speech at Newton Abbot on 6 March, Baldwin placed economy firmly in first place in the list of the "four essential points" of the Conservative programme.34 This priority became even more markedly evident in the leader's speeches in the months after the cessation of the Crusade campaign after the stornoway house agreement; in major deliberations on party policy at Liverpool on 28 April, and at the National Union Women's Conference rally, speaking to the delegates of the local constituency voluntary workers, at the Albert Hall on 15 May 1931.35 The priorities outlined in this latter oration: economy

32. Smithers to Fry, 12 January 1931, Baldwin MSS, volume 47 , ff. $233-235$.

33. The Times, 9 January, 30 January, 4 February, 27 February, 5 March, 18 April 1931, et. al.

34. Ibid., 7 March 1931.

35. Ibid., 29 April, 16 May 1931. 
foremost, the problem of foreign dumping and the solution in the shape of the emergency tariff second, followed by a vague promise to help agriculture, and no discussion of the imperial dimension at all; in fact was a hierarchy of issues exactly in tune with the state of mind of grassroots Conservatism in the localities in the early summer of 1931.

The economy question had been taken up in the local associations even before becoming an issue with the parliamentarians. 36 Their approach to the economic crisis was clear-cut: that "in view of the grave financial crisis" the remedy could be found in "immense and immediate reductions in public expenditure coupled with an emergency tariff on foreign manufactured articles so as to protect our industries" which "affords the only means of economic salvation". 37 The remedy "aims at the relief of unemployment by a restoration of industry" through "a reduction in expenditure and taxation", backed up by safeguarding and the development of empire trade.38 The degree of rank and file concern was shown by the issuing of a circular letter to all Conservative Associations by the Esher constituency party, rousing the localities and calling for a chorus of resolutions on economy in February

36. Dulwich CA, Res., NU Exec., 13 January 1931.

37. Somerset Prov. Div., Council AGM, 13 February 1931.

38. Yorks Area, Ann. Report, Council, 24 January 1931; Eastern Prov. Area, Res., NU Exec., 12 May 1931. 
1931.39 In fact, the expenditure issue was the main item of comment within the local associations in all discussion of policy matters during 1931, and the message was clear that for them, economy took priority over all other policies. 40 After the acknowledgements of the seriousness of the position by the government, in particular after the budget debates of April 1931, the national peril was admitted. Votes of censure on economy were moved on several occasions by the Conservative front bench, and a national campaign for economy launched to act as an umbrella for both Conservatives and Liberals eager for reductions. By the early summer of 1931 the issue had become not less, but even more, crucial a concern, and the speeches of leading Conservatives were couched in the language of alarmism. In January Hailsham had warned that "if the burden placed on industry and property increased the whole economic structure of the nation might collapse".41 This danger became the keyword of the speeches of the spring and summer months: that "the

39. Esher CA Circular, copy and resolution endorsing same, York CA, Exec., 9 March 1931; South Kensington CA, Exec., 19 February 1931.

40. Scottish Unionist Association, An. Conference, Resolution No. 1, 12 December 1930; Petersfield CA, Council AGM, 27 February 1931; Flintshire CA, AGM, 14 March 1931; City of London CA, AGM, 13 February 1931; North Cornwall CA, AGM, 13 March 1931; West Dorset CA, Exec., 30 January 1931; Halifax CA, Res., NU Exec., 19 February 1931; Kettering CA, Res., ibid., 12 May 1931; Wessex Area, Metropolitan Area, Res., ibid., 16 June 1931; Lancaster CA, An. Report, 1931.

41. The Times, 30 January 1931. 
financial stability of the country was in danger, and unless we retrenched we were heading straight for bankruptcy and ruin". 42 This was the theme summed up by Neville Chamberlain's speech at Newcastle on 13 June 1931, which warned ominously of "national bankruptcy". 43

Not unnaturally, such a serious situation produced considerable pressures for unity amongst Conservatives, exemplified in the public manifesto of support for Duff Cooper in the st. George's campaign issued by prominent businessmen and bankers. 44 Economy as the key issue pushed into the background both protectionism and the India question, and equally supressed a third, as yet undiscussed, area of internal party controversy; the revolt of the younger politicians against the domination of the party by the group described by the epithet the old Gang'. This sentiment affected the younger generation in all parties, 45 and was one of the facets which, cutting across the party boundaries, symptomised the general political uncertainty and reappraisal of the 1929-1931 period. Within the Conservative party, the peaks of the agitation of the younger men coincided with Baldwin's worst periods of parliamentary incompetence, policy vagueness, and personal aloofness - in brief, with the periods of lowest party morale: in November and December 42. Ibid., 7 March 1931.

43. Ibid., 15 June 1931.

44. Morning Post, 17 March 1931.

45. Observer, 2 November 1930. 
1929; the late summer of 1930; and February to March 1931.46 Baldwin's personal remoteness from the younger generation, and apparent reluctance to promote any of them, or dispense with any of his more elderly colleagues, was at the roots of the '0ld Gang' agitation. 47 This maladroitness hid the fact that the young men, apart from a small minority of a nascent Diehard orientation, were mainly sympathetic to Baldwin's line and style in politics. It was, in reality, his lack of vigour which was the problem, and which led the younger men to flirt with alliances with politicians they would not normally be in sympathy with, such as Lloyd George and Oswald Mosley, entirely due to their overriding frustration at the lack of energy in the Conservative front bench leadership, who were considered as "stale" and "wooden".48 The 'old Gang' syndrome was a condemnation and a symbol of the lack of drive amongst the leadership in the eighteen months after the 1929 defeat: "the younger men of the Conservative party can expect nothing either by way of courage or inspiration from our present leaders", declared one malcontent in November 1929.49 One product of this was a willingness to applaud anyone who gave the appearance of 46. Memorandum of discussion of young MPs, by Macmillan, 5 November 1929, copy in Beaverbrook MSS, C235; Whitehall diary, 26 october 1930.

47. Derby to N. Chamberlain, 9 March 1931, NC 8/10/25.

48. N. Chamberlain to Bridgeman, 18 November 1930 , Bridgeman MSS, SRO $3389 / 106$.

49. Hall Caine to Beaverbrook, 20 November 1929 , Beaverbrook MSS, B94. 
energy, an instinct which led first to sympathy with Beaverbrook's Crusade in its earlier stages, 50 and second to a community of feeling amongst the 'economic radicals', drawing together the Crusaders with Lloyd George's platform and, above all, with the movements initiated by the young man in politics par excellence, Mosley. 51 In fact, the tension between the attraction of vigour and the instincts of party loyalty, the confusion:over policy complicated by the frustrations of idle young men with abilities and ambitions, all combined to produce an atmosphere that was, paradoxically, both alarming for the party leadership, and yet ultimately ineffective. 52 Much of the young men's movement was hot air: the compiling of cabinets and cliques on the back of menu cards, the thrill of secret meetings with Lloyd George or with Mosley; and almost all of it evaporated in the cold atmosphere of political realities. If the Conservative young men looked to any individual as a leader amongst themselves, it was probably Walter Elliott.53 Yet when Elliott in a letter to The $\underline{\text { Ti }}$ 프로 indicated sympathy with Mosley's ideas, he was quickly pulled back into line by Baldwin, and promptly

50. Mond to Beaverbrook, 20 March 1930, ibid., C244.

51. Beaverbrook to Mosley, 17 July 1930, ibid., C254; Tom Jones to E. Jones, 3 March 1930; Skidelsky, op. cit., pp. $276-277$.

52. Dawson to Willingdon, 16 December 1930, Dawson MSS.

53. Jones to Moorhead, 20 January 1931, Jones diary. 
dropped any plans for cross-party groupings.54 When Mosley broke away and formed his New Party, only one Conservative MP, the Ulster Unionist W. E. D. Allen, joined him, for the remainder were held back by the combination of personal distrust of Mosley and a pragmatic conformity to the established parties.55 Nonetheless, the mood of hostility to old party shibboleths was very marked, and represented something more significantly and widely felt than merely the rhetorical cloak of ambitious, rising figures, for it synchronised with the feeling that party politics were in the melting pot, and could and should be recast in the image of a younger generation. And it was in the guise of this general feeling - admitted to by the very members of the "old Gang". themselves rather than the practical ineffectiveness of the young men's movement, that these sentiments gave rise to considerable anxiety and discussion between the leaders in 1930 and 1931.

As a result, in the period of settlement in october and November 1930, the party leadership moved to appease the "Old Gang" agitation, which was also being used now as a cover by the even older Diehards, by the circulation of a self-denying ordinance amongst the front benchers, which

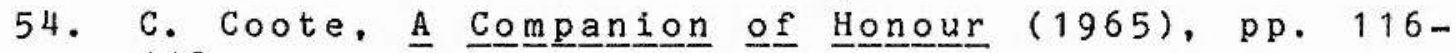
118 .

55. Allen to Beaverbrook, 28 May 1930, Beaverbrook MSS B 123; Allen to Baldwin, 9 March 1931, Baldwin MSS, volume 166, ff, 2-4; Lockhart diary, 13 February 1931. 
enabled Baldwin publicly to reassure the party that his hands were free to appoint whom he pleased on his return to office.56 This appeasement was a crucial factor in stemming the tide of Conservative dissatisfaction, so that when Mosley formed the New Party the young turks' impotence was revealed. But there were also fundamental and structural reasons for the failure of the young men's revolt to materialise into more conorete form. In reality, the idea of breaking away from the party was not as attractive as it had been to talk about. Fusion with the like-minded of other parties did not seem practicable in details, and joining any of the other parties was not an enticing prospect; Mosley's venture was admired only from afar.57 The young men's clique was small in number, but comprised rising talents such as Oliver Stanley and Anthony Eden, who already had their feet on the ladder of party patronage and promotion, and had too much to risk by disloyalty. Apart from such expediency, many of the young men on the left of the party, such as Duff Cooper, were determined to continue the struggle for the soul of the Conservative party as Baldwin's aids against reaction, and whilst their protectionism separated them from his policy in mid-1930, by and large India reunited them with him in 1931. In 56. Bridgeman to Baldwin, 15 November, 26 November 1930, Baldwin MSS, volume 165, ff. 35-39; N. Chamberlain to Bridgeman, 1 November 1930, NC $8 / 10 / 16 \mathrm{c}$; NU Council, 25 November 1930.

57. Harold Nicholson Diary, 30 May 1931. 
addition, the primacy of the 'economy' cry and the reality of the slump washed away the 'new' ideas, for these had always been vague in concept, aspirations rather than blueprints, and the majority of the young men accepted both the national peril and the need for unity, and the deflationary economic strategy. The young men's ideas and movement existed through its very vagueness; if defined it would have only disunited its proponents, and so it could only be pinned down to hostility to the continued control of the pre-war generation. 58 The young men's clique was not coherent in policy or in principles; it contained Diehards who were anti-Baldwin at the second Caxton Hall meeting like Marjoribanks but also semi-socialists like Macmillan; out-and-out tariff reformers, and neo-free traders such as Elliott and Hartington; financiers, but also agriculturalists like Lymington. Any coherence the group had was the accidental result of the link of youth, and of party circumstance and a sense of frustration - the product of the generation gap and a wide breach of sympathy with the pragmatism and caution of the leaders. Once that breach was mended by early 1931, and the younger MPs reassured of their prospects, the bulk of them settled down, in the atmosphere of patriotism, unity, and national emergency, to work for victory at the next election without having restructured the party or its policy.

58. Whitehall diary, 26 october 1930. 
The restoration of order and unity in the Conservative ranks first pushed into the background the divisive issues within the party which were separating the anti-Socialist forces, and second propelled it towards alliance with the Liberal right. One immediate product of the economy campaign was to foster a reconsideration of the thorny question of relations with the Liberal party, which held the parliamentary balance - and thus the life and death of the Labour government - in its hands. This contrasted sharply with the attitude of hostility to the Liberals typical of the early months of opposition, a hostility which many Conservatives found difficult to overcome even when, due to the overriding necessity of the national crisis, co-operation and coalition became necessary. Hostility to the Liberals was based more on the events of the 1920's than upon the pre-1914 party divides. Anti-coalitionist feeling was still running very high in the party, as were suspicions of the excoalitionists.59 This was matched by the antipathy to Lloyd George, for his coalition past, for his role in the 1929 election, for his support of the Labour government, but above all, for his supposed unprincipled untrustworthiness: "he is the political enemy of everything we think and want to do", wrote Horne in

59. Lane-Fox to Irwin, 11 December 1929, HaIifax MSS, India Office, Eur. C. 152/18/1/328. 
January 1931: "I think he is playing his game with a cynical unconcern for national interests". 60 The rank and file of the party blamed the Liberals for the loss of the 1929 election with a peculiar bitterness, both for their intervention in such a large number of contests, and their election promises. MPs spoke of "our betrayal by the Liberals". The moral was clear: co-operation with Lloyd George and his followers was a political impossibility in the post-election atmosphere.61 This feeling was reinforced by the Liberals' support for the Labour government in the division lobbies on decisive issues such as the Coal Bill of December 1929.62 However, the principal issue which kept Conservatives and Liberals apart during 1930, and tied the Liberals to Labour, was the electoral reform conference, to whose provisions the Liberals looked for the salvation of proportional representation, but by whose reforms the Conservatives stood only to lose their advantages of better finance, plural voting, and the University representation.

Some Conservatives suggested attempting a deal with the Liberals in the electoral reform conference, as their identification of Labour as the greater danger became 60. Horne to Beaverbrook, 23 January 1931, Beaverbrook MSS, C178.

61. Crichton-Stuart to Baldwin, 3 June 1929; Colfox to Baldwin, 1 June 1929; O'Connor to Baldwin, 5 June 1929, et. al.; Baldwin MSS, volume 36, ff. 218-269; volume 37 , ff. 60-155; see also chapter 1 .

62. Lane-Fox to Irwin, 22 December 1929, Halifax MSS, Eur. C. $152 / 18 / 1 / 333$; Balfour, op. cit., p. 71 . 
firmer.63 Certainly the principal concern of the Conservative delegation, led by Hoare, was to try and prevent any further consolidation of the Lib-Lab front, an endeavour in which, by an adroit exploitation of tactics and of divisions on details between the other two parties, he was largely successful, so that the conference in the end dissolved.64 In 1930 dealing with Lloyd George was ruled out by party sentiment and by practicalities; the Liberal MPs themselves were uninterested, and Lloyd George "could not deliver the goods".65 The party preferred to await the oft-anticipated collapse of the Labour government, or to work towards an accommodation with the right-wing of the Liberals that would not involve either alliance with Lloyd George, or concessions on tariffs or electoral reform. Co-operation with other groups was made absolutely conditional upon the fact that it must not water down the protectionist policy arrived at in October 1930, a commitment made public by Baldwin in December in the knowledge that it ruled out alliance with the Liberals.66 This latter standpoint reflected the fact that by January 1931 the Liberals had entered into

63. Hugh Cecil to Baldwin, 28 July 1930, copy, Salisbury MSS, S(4) $136 / 85$.

64. Hoare's memoranda on electoral reform conference; Templewood MSS, VI/2, Salisbury MSS, S(4) 136/62-63, Baldwin MSS, volume 52 .

65. N. to Ida Chamberlain, 22 March 1930, NC 18/1/686; to Baldwin, 19 April 1930, Baldwin MSS, valume 31, ff. 89-90.

66. The Times, 18 December 1930. 
something akin to a coalition with the Labour govenment, and were thus principaliy responsible for its continued existence throughout 1931. The period of the Lib-Lab 'pact' denoted the peak of Conservative-Liberal hostility: the Liberals "had allowed themselves to be so tied up with the Government ... that the Liberal Party was neither fish, flesh, fowl, nor good red herring", was only one example of the torrent of abuse rained down upon Liberal heads by Conservative speakers during 1931.67

This picture of feeling in early 1931 did not seem to present much likelihood of a Conservative arrangement with the official Liberal party, unless a section of Liberals made themselves more amenable, or a national disaster should stampede the Conservatives into a government of national unity. In fact, both phenomena occurred: the former in early 1931, the latter in August. The events of 1931 moved together both the Conservatives, and the right wing of the Liberal party headed by Sir John Simon. Due both to electoral anxiety for their seats, and a genuine community of viewpoint over the economic consequences of the continued existence of the Labour government, the Simonites moved closer to the Conservative position at the same time as the overriding rhetoric of 'economy' made the latter more desirous of such an alliance. The crucial. point, however, was the public acceptance by the simonite Liberals in slow stages during 1931 of both the rhetoric 67. A. Chamberlain at Chester, The Times, 31 January 1931; Gower at Gillingham Conservative Club, 14 November, Gower MSS. 
of economy, and their consequent abandonment of free trade for the emergency tariff. 68 As a result of these public moves over economy and protection the simonites became politically acceptable allies for Conservatism without provoking internal party complaint, principally because Simon himself was seen as "rapidly coming our way".69 Simon was already a respected figure in Conservative circles, for his India Commission Report of 1930, his distancing himself from requests for electoral reform, and his repudiation not only of the Lib-Lab pact but also of Lloyd George himself - culminating in his resignation of the Liberal Whip on 26 June 1931 . As a result Conservatives drew a distinguishing line between the section of Lloyd George and Samuel who moved closer to the government, and Simon's group, to whom they held out a hand in public:

Conservatives were proud to fight side by side with such men as Sir John Simon, and they could honestly say to him and his friends that their programme was broad-based upon the national needs, and that there was no reason why they should not work together to carry it out.

This programme was, of course, the business and Conservative one of limited insular protection and

68. The Times, $30 \mathrm{January;} 14 \mathrm{February;} 4 \mathrm{March} ; 15 \mathrm{May}$, $1931 ;$. Chamberlain diary, 5 December 1930, NC $2 / 22$.

69. Hannon to Beaverbrook, 10 June 1931, Hannon MSS 18/3; N. to Ida Chamberlain, 5 December 1930, NC 18/1/719; The Times, 12 December, 15 December 1930.

70. Hoare at Chelsea, The Times, 21 April 1931; ibid., 15 May, 29 June 1931. 
rigorous economy, and Liberals who accepted this became the 'best type' of 'patriotic' Liberals, with whom as a consequent result of this common ground a deal on seats at the next election became not a sordid intrigue but an honest alliance, with parallels frequently drawn to the late nineteenth-century Liberal-Unionist arrangement. 71 The negotiations on seats which progressed intermittently from March 1931 were the first product of Simon's protariff and economy Manchester speech of $3 \mathrm{March}$, and were dependent upon the fiscal acceptability of the simonite manifesto's political content. 72 The second product of this realignment of the anti-Socialist forces behind the Conservative banner would be, it was hoped, the fall of the Labour government when the House of Commons reconvened after the summer recess of 1931, and the third result would be the avoidance of splits in the anti-socialist vote at the ensuing general election by a mutual withdrawal of candidates. This model paralleled and reflected - but was not the sole cause of - the optimism prevailing in Conservative circles by mid-summer 1931 in regard to both the imminence of a dissolution, and the prospects for a Conservative victory and return to power that this now offered.

71. Ibid., 7 March 1931.

72. N. to Ida Chamberlain, 7 March 1931, NC 18/1/729; ibid., 18 April 1931, NC 18/1/734. 
Although the internal condition of the party had been essentially healthier since the accommodation of the leadership with the grassroots in October and November 1930 the restoration of order followed on most evidently from the crisis of March 1931. The Stornoway House pact with Beaverbrook, and the clearing of the air in the shadow cabinet at the end of that month had begun the process.73 However, of more significance were the consistent and increasing pressures for party unity, which had made themselves felt since the period of the East Islington contest and the growing primacy of the 'economy' agitation, for it was as a result of these pressures that the internal party settlement of March 1931 was not only arrived at, but preserved intact. In contrast to the previous shortlived restorations of control in November 1929 and March, June, and even October, 1930, the unity achieved in the spring of 1931 endured, as a result of the new-found stability in Conservative politics. In this restoration of order one factor was the advance of northern and free trade opinion to, for perhaps the first time, an acceptance and even an eagerness for protection. The main pressure for unity, however, was the accepted primacy and urgenoy of anti-Socialism, of defeating the Labour government at the earliest possible opportunity. This was clearly the message from the constituencies; "it would be a calamity if, at a time when we have the Labour 73. N. Chamberlain to Cunliffe-Lister, 26 March 1931 , Swinton MSS, SWIN I (174) $2 / 1$. 
party on their knees, there should occur any serious rift which would divide the Conservative forces."74 This concern was acute in 1931 , in a sense in which, notwithstanding normal party antagonism, it had not been during 1929 and 1930. By the spring of 1931 the existence of the Labour government was regarded as a national calamity, and its continued existence generally held by Conservatives to be a national peril. The Diehard MP Gower told his local association annual meeting

that he desired to emphasise with all the force that he could the imperative necessity there was for all Conservatives ... to unite and fight under one banner at the coming election in order to dismiss the Socialist [government] .... Questions of party leadership or of details of policy or programme were really of minor importance when compared to the importance which existed for turning the present government out ... if through dissenions in the Conservative Party the Socialists did obtain a renewal of their lease of office it would spell the ruin of this old country and of all classes of its community.

In this atmosphere unity was prized above all else, and, as the extent of the pressure for unity was directiy proportional to the degree of anxiety felt about the national situation, so these forces increased in effectiveness during the summer months of 1931. The

74. White (leader of the party in Liverpool) to Derby, 6 February 1931, Derby MSS, 920 DER (17) 6/33; Reigate CA, AGM, 18 March 1931; SUA, Eastern Divisional Council, 25 March 1931.

75. Gillingham CA, AGM, report dated 25 March 1931, Gower MSS. 
catchword was 'closing the ranks', and closing the ranks inevitably meant a drawing together around the position taken by the leader, with dissidents shifting their ground towards his, thereby reducing any need for the leader to move to accommodate them. The very way in which the words were used indicated the power of the leader's position and the pressure, perhaps unconscious, for conformity. This was apparent, significantly, even over the question of India where Baldwin's position least resembled a consensual nexus; at the meeting of the party's India Committee on 22 June, after Irwin himself had attended and presented his apologia, the pressure for unity overcame the doubters, and "a strong appeal" was made "that every effort should now be made to close up the ranks in order that the Conservative Party might show a united front".76 Even Churchill was responsive to this mood, and, although still concentrating on the India issue, promised that "he would take no factional attitude". 77

closing the ranks was more than just an exercise in papering over fundamental rifts. The concerns of party policy by mid-summer 1931 reflected a new position of consensus within the party, possibly to a greater degree than at any time since 1918. This was especially true in the case of tariff reform, a policy that had consistently

76. Unionist India Committee, The Times, 23 June 1931. 77. The Times, 13 July 1931. 
divided the party, most obviously on a regional northsouth/urban-rural basis, since its formulation in 1903. At that time Joseph Chamberlain had looked to a serious depression in the free trade economy to turn opinion to tariff reform, and with the economic blizzard of 19301931, that was indeed what finally occurred, uniting all sections of the party behind the policy. This development was exemplified by the Commons resolution tabled by Page Croft on 29 June 1931, and to which all the Conservative backbench MPs except six attached their names; this represented a degree of party unity behind the tariff case that had never previously been attained. 78

Tariffs, however, although in the forefront of the party programme, were not the foremost concern. Indeed, there was an attempt by Baldwin in his presentations of policy in summer, 1931 to defuse the dangerous immediacy of the food tax element, in the interests of securing the necessary moderate votes at the next election, by producing the idea that tariffs would be devised and formulated by an above-party Royal Commission. 79 This was made acceptable by the fact that in the interim, the emergency tariff would be imposed. This would protect domestic industries, but avoided much of the implications of a whole-hogger imperial preference position. It was revealing that this apparent watering down of the policy 78. House of Commons Debates, fifth series, volume 254 ,

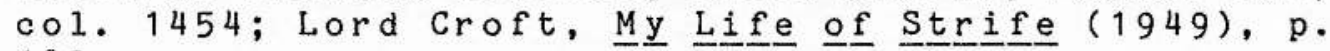
183.

79. The Times, 18 July 1931. 
by Baldwin did not, on this occasion, produce how ls of outrage. Partly this was because the emergenoy tariff gave most Conservatives what they urgently sought in the domestic dimension, whilst the commitment to call an imperial conference and set up the tariff commission appeared to be a firm promise for the future in the imperial dimension. It was also, however, because in the political atmosphere of mid-summer 1931 the issues which had dominated the party's attention in the previous two years had been displaced by other concerns, and because of the overriding impulse for unity. On the two key areas of protection and India, Baldwin provided a policy in mid1931 which, although it did not satisfy the faddists of either position, was adequate for the broad majority of the party. Just as the emergency tariff was an acceptable consensus in one area, so were Baldwin's publicly stated commitments to specific safeguards in any Indian constitution in the other, sufficient to secure unity on his own terms. 80

Other issues drew the party together in opposition to the Labour government during this period. The provisions in the 1931 budget for a tax on land values revived memories of the party's long-standing opposition to such policies throughout the late-Victorian and Edwardian eras, and drew all sections together. So also did another partisan question from the more recent past: the attempt 80. Ibid., 19 June 1931. 
of the Labour government to reverse the industrial verdict of 1926 by repealing the Trades Disputes Act of 1927. Tha measure had been perhaps the most popular product of that Baldwin administration in the eyes of the party rank and file, and they were determined that the party should fight tooth and nail to forestall what they viewed as the government's surrender to the sectional interests of the TUC, and to prevent the legalisation of general strikes. The fervour, passion, and bitterness of feeling this issue aroused amongst the party rank and file can hardly be over-estimated, and, coming as it did from all regions, it acted as a powerful spur both to unity and to invigorating the parliamentary opposition. 81

Economy was the issue which, above all others, had come to hold by general agreement pride of place in the party manifesto by June 1931 and to receive the foremost attention in the speeches of the leader, in those definitions of policy given by Baldwin at Hull on 17 July and Knole Park on $25 \mathrm{July} .^{82}$ The practical product of the economy question was the adoption of the proposal of the means test to regulate the dole, and the effective decision that the level of benefit must be reduced, although this was to some extent disguised by Neville Chamberlain, who sought:

81. Resolutions. from East Midlands, Lancashire and Cheshire, and Northern Counties Areas, NU Exec., 19 February 1931; from Somerset Prov. Division and the Metropolitan Area, ibid., 10 March 1931.

82. The Times, 18,27 July 1931. 
from the political point of view to shift the issue from 'the Tories will cut your dole' to a constructive scheme of a more attractive kind ... it would be a much better plan from the social point of view.

Although in this way the effective consequences of the economy policy were relegated to the vague background, the advantages of the policy were not. The whole point about the 'economy' issue was that it was much more than just a negative standpoint. Because the depression was seen as being the result of the loss of business confidence and incentive, principally due to the high level of rates and taxes, so it was believed that by the very action of a Conservative government coming into office committed to cutting such taxes and safeguarding industries, there would be an "instantaneous revival of confidence in every walk of British 1 ife". 84 Worthington-Evans had made this point the keynote of the vote of censure debate on economy only days before his death in February, speaking from the opposition front bench. For the City, he declared:

the most rigid economy is the greatest need of the nation. The Government persist in their policy, although there are clear signs that it is creating a want of confidence both at home and abroad. Without confidence there can be no enterprise, and without enterprise there can be no revival of employment.

83. N. to Hilda Chamberlain, 20 June 1930, NC 18/1/744.

84. The Times, 21 April 1931. 
If the government were turned out:

the psychological effect will be immediate. The first step would have been taken. Confidence would be restored, employment would speedily improve.

Agriculture still received frequent mentions in the programmatic speeches of mid-1931, but its prominence had waned compared to 1929. Not only was it usually relegated to a low position on the list of urgent topics, 86 but it was also usually referred to in passing in the studiously vague terms of 'help' for agriculture - which could be taken to mean almost anything, or almost nothing. This contrasted with the fact that the concerns of industry and finance received specific and prominent attention, a fact which reflected the evolving nature and ethos of the Conservative party in the inter-war years. Reduction of expenditure was placed in the vanguard, and a pledge given to specifically impose an immediate emergency tariff, which would mark at least the end of 'Cobdenism'. Party policy was uniformly presented in a four point programme in the summer of 1931, reflecting the extent to which agriculture, and imperial concerns, had been pushed to the bottom of the list when compared to the question of domestic finance:

85. House of Commons Debates, fifth series, volume 248 , col. 427,11 February 1931.

86. The Times, 27 July 1931. 
The Conservative Party had a policy... it had been summarised under four headings: economy, protection for our home industries, help for agriculture, and the development of Imperial Trade and Imperial Unity. The nation's finances had now reached a point when it was absolutely essential that there should be some reduction in national expenditure.

With unity established around that four-point programme, and with the pressures to maintain that unity effective throughout 1931, the internal condition of the party showed a marked improvement over the first two months of the year. There was "a general feeling of renewed courage and determination" which could be seen in the improved morale and the improved level of attendance of Conservative MPs.88 Neville Chamberlain's conduct of the opposition to the 1931 budget was a particular success, and marked the final stage of his emergence as the second figure in the party - an emergence which had, in fact, a steadying force of its own.89 The improved performance of the opposition front bench in attack during the summer of 1931 also served to cloak what remained of Baldwin's deficiencies as an opposition leader, but even in this department there was improvement, partly as a result of the 'clearing the air' in the shadow cabinet in March, but mainly as a result of Baldwin's conclusion that

87. Ibid., 16 June 1931; 16 May, 15 June, 24 July 1931.

88. Moore to N. Chamberlain, 31 March 1931, NC 7/11/24/24; The Times, 24 June 1931.

89. N. to Ida Chamberlain, 18 April 1931, NC 18/1/734; N. to Hilda Chamberlain, 2 May 1931, NC $18 / 1 / 736$. 
public opinion had swung to a sufficient extent to make vigorous attack a safe and sensible option.

The improved internal condition of the party was also revealed by the minimal concern shown over the occasional rumblings of dissatisfaction from Beaverbrook after the Stornoway pact. These partly concerned the difficulties over the position of the Crusade MP sitting for south Paddington, but were principally the result of Beaverbrook's suspicion that Baldwin was welshing on the agreed policy, especially over agriculture.90 In fact, one by-product of the shelving of the agricultural interest during 1931 was Beaverbrook's progress towards basing his campaign on the dissatisfied section of agriculturalists. This was not because he had.given up the concept of empire free trade, though by the time of the Stornoway pact of 1931 he had come to realise the difficulties posed by dominion reluctance, but it was, at least at first, a tactical move to increase pressure. Beaverbrook well knew that his propaganda was not a powerful force on its own, but that it needed to mobilise and vocalise a real dissatisfaction amongst rank and file Conservatives. By April 1931 the only group available were the farmers, with whom Beaverbrook had begun and ended in alliance from Lewes in 1929 to Stornoway House in 1931. Single-issue pressure group campaigns were always Beaverbrook's political metier, and thus it was hardly 90. On South Paddington, see NC $8 / 11 / 24-75$; on agriculture in particular, NC 8/11/70-71. 
either surprising or illogical that his Crusade evolved during 1931 into the Agricultural Party; food taxes were the common ground for both. 91 This latter venture never had the appeal or success that the Crusade had possessed. Apart from an irreconcilable element in Norfolk, Lincolnshire, and some parts of rural East scotland, the campaign could not attract grassroots support.92 The reasons for this included the acceptance by many Conservatives after the East Islington and St. George's by-elections of Baldwin's strictures upon the press lords. But the reason above all others for the failure of this venture was the pressure for party unity so strongly felt during the growing national financial crisis of 1931, from February until after the August smash. It was not just the simple fact that the concerns of finance and industry had shouldered aside the economically weaker farming interest, but also that the agriculturalists were themselves possessed of the same economic ideas, and were thus as receptive as any other group to the cry for economy.93 Indeed, in one sense this could be portrayed as being the long-standing campaign of the counties over

91. Beaverbrook to Rothermere, 12 January 1931; to Dykes, $4 \mathrm{July} 1931$; to Pinckard, $20 \mathrm{July} 1931$; correspondence with J. H. Macdonald, January-December 1931; Beaverbrook MSS, C285, B194, B203, B201.

92. Observer, 25 January 1931.

93. National Farmers Union, Parliamentary Committee, 17 March 1931: Eastern Provincial Area, AGM, 5 February 1930 . 
eighty years to secure reductions not merely in national expenditure but in the 'burden' of local taxation.94 Thus 'economy', of all the available range of issues, was the best rallying-cry for the forces of anti-Socialism, and as it was allied only to the less objectionable' 'revenue' or 'emergency' tariff, it posed no barrier to drawing into the fold the 'patriotic' Liberal element. The party programme enunciated in July 1931 was therefore in tune with the electoral and tactical concerns of the party, designed both to eject the Socialist government and restore a new national consensus. As the by-product of this process, both the unique sectional claims of agriculture, of the Indian trade, and of the imperial federationists, were relegated to the background of the political stage.

There could be little doubt by the end of July 1931 that the course of British politics was moving perceptibly in the direction of a Conservative government returning to power in the near future. All the indicators suggested both that the Labour government had not long to live, and that the Conservatives and their simonite allies would win the following general election. The shift of opinion in favour of the Conservative economic policy was gathering pace into a veritable landslide. Neville Chamberlain was reliably informed by a local figure in May 1931 that "we should sweep Lancashire and Yorkshire at the next

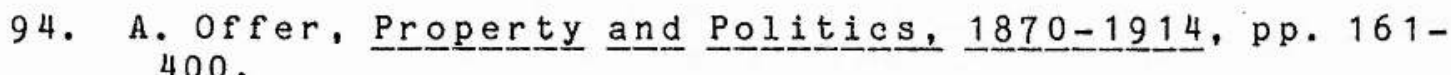


election".95 The by-election results of April to July 1931 confirmed this impression. An early harbinger was the Conservative gain at Ashton-under-Lyne on 30 April, but the lesson was driven home by three by-elections in June 1931, which proved in the event to be the last of that parliament: Gateshead on 8 June; Manchester Ardwick on 22 June; and Liverpool Wavertree on 23 June. Though none of these changed hands, the scale of the'swing to the Conservatives was enormous, being calculated as: fourteen per cent, ten per cent, and eleven per cent respectively.96 The crucial significance of these results was their geographical location, for they indicated to Balwin that his pragmatic strategy was bearing fruit, and that in the coming election the ground lost in the industrial north in 1929 would be regained - and with it, command of the House of Commons. Of all the results, that at Gateshead was the most encouraging, for, as Baldwin himself remarked, it was "the first one in which there has been a real swing of votes in an industrial area."97 Hannon noted that "the Gateshead election has had considerable stimulating effect in the House of Commons", and that Conservative MPs "have become quite bright and

95. N. Chamberlain to Hilda Chamberlain, 2 May 1931, NC $18 / 1 / 736$.

96. C. Cook and J. Ramsden, eds., By-Elections in British Politics (1973), p. 78 .

97. The Times, 19 June 1931; ibid., 2 May 1931. 
cheerful".98 Experienced electoral strategists were convinced that the party was now headed for ; $v$ ictory on the lines and scale of that after the previous Labour administration in 1924, and would have agreed with Baldwin's claim of 28 June that "there was not a seat in England that could not be won".99

This optimism over the electoral position went handin-hand with pessimism over the national situation to produce unity. These pressures did not lead to the bitterness that can be engendered by futile opposition as had perhaps partly occurred during the early period of Liberal-Labour alliance in February 1931 - because by June the by-elections demonstrated unmistakably "that the whole position has begun to slide away from under the present government". 100 The electoral position looked promising, as did the state of party policy, and this was matched by the improvement in the tactical position during 1931. outside parliament, the Stornoway House pact with Beaverbrook on one hand and the arrangements arrived at with the Simonites on the other, reduced the likelihood of any splits reducing the maximum potential of the antiSocialist vote. The apathy so remarked upon in 1929 and 98. Hannon to Beaverbrook, 10 June 1931, Hannon MSS, $18 / 3$.

99. Baldwin at Himley Park, The Times, 29 June 1931; Bridgeman journal, volume 2 , note after p. 243; A. Chamberlain to Armstrong, 6 November 1931, AC 39/3/41; Lord Londonderry, The Times, 15 June 1931; for local parallel, Denbighshire $\bar{C} \vec{A}$, Annual Report, 1931.

100. The Times, 29 June 1931. 
until early 1930 had vanished as the mist before the dawn of the national financial crisis, and, as a result of the frequent scares over the possible fall of the government, the local associations were prepared for an election at any time. Inside parliament, secure in the knowledge of the swing of public opinion, the Conservative party began for the first time to use its hold in the House of Lords to wreck controversial government legislation, in a deliberate attempt to force a dissolution. In the Commons it was anticipated that, as a result of the Government's own internal weaknesses, that if it lasted to the recess it would fall on the re-opening of parliament in autumn 1931. The result of all these factors coming together was first the restoration of order in the party, and second the imminent anticipation of victory:

there has been a complete change in the outlook of Conservative members and in almost every buzz of conversation one heard Conservative members declaring that in the altered circumstances they'did not care how soon a General Election came upon us:

The dominating theme of the period from the winter of 1930 until the crisis of August 1931 was the increasingly evident fact that the internal party crisis had become overshadowed by a national crisis. Given the self-image of Conservative politicians and their conception of the role of their party as the defender of the realm when in peril, such a realisation caused the supercession of the 101. Hannon to Beaverbrook, 1 April 1931, Hannon MSS $17 / 1$. 
debate over the future path of the party. Thus the politics of Conservatism were fundamentally reordered from the posture of 1929-1930. Primacy was now placed upon party unity. It was one face of that unity that further internal assaults to change party policy - on empire trade or on India - were now counted out. It was the other face which dictated that equally in order to maintain and preserve that united front the policy advances of 19291930 should and must be retained as the basis of any Conservative programme. Thus the impact of the financial crisis of 1931 was to fossilise the evolutionary process in Conservative party policy for the foreseeable future, in the two senses of both arresting any further development, and of preserving in tablets of stone the existing attitudes and remedies arrived at by July 1931. All of these policies, fossilised as they were, provided the bedrock of Conservatism in the National Government formed in August 1931: the commitment to the economic policy summed up by the term 'economy', to the emergency tariff, and to the Irwinite line on India. 
National Crisis and National Government: The Patriotic Sacrifice of Party, August 1931

The formation of the national government of August 1931 has proved to be a crisis of enduring fascination for historians. The effects of the events of the last week of August 1931 and the transition made between that time and the formation of a permanent National Ministry after the general election of october 1931 had profound consequences for the political history of Britain during the ensuing fourteen years, if not longer. As a result of the significance of the events of August 1931 much attention has been directed towards the question as to whether and to what degree such an outcome was already in the minds of politioians before the financial crisis broke upon them. As a result, toomuch weight has been given to those few and scattered occasions when Ramsay MacDonald acknowledged the minority position of his party in the Commons with references to the House acting more in the capacity of a Council of state, and to those occasional and unavoidable contacts between the party leaders over membership and attendance of the various official and semi-official conferences and commissions. The old theory of a plot between MacDonald and Baldwin is now surely exploded, and certainly there is nothing in the contacts or correspondence between them to suggest anything more sinister than the fact that they did not dislike or despise each other. However, other 
theories remain, suggesting either that general sentiment in favour of a national government as superior to party government permeated the political atmosphere with increasing effect in 1931,1 or that the formation of the government, though no conspiracy, was the result of "a Conservative party bid for power", in which "[Neville] Chamberlain pursued a strategy that ensured the downfall of Labour and prepared the way for a National Government under Conservative control". 2 In fact, the actions of the Conservative opposition were not so purposeful during the August crisis, which buffeted their party and blew it of course at least as much as it did the Labour party. The strategy the Conservatives followed concentrated not upon the destruction of the Labour ministry or of the Labour party, but upon the one issue which they had already come by the beginning of August 1931 to make the foremost on their agenda: reduction of government expenditure and of the 'burdens' of taxation. Considerations of the 'national interest', of 'patriotism' and of 'duty' evidently affected the attitudes of Labour leaders; what has been less remarked upon is that they equally, if not more, affected the decisions taken by the Conservative leaders, who believed, with some justification, that in

1. R. Dare, "British Labour, the National Government, and the 'National Interest', 1931 ", in Historical Studies, volume 18, 1978-79.

2. J. D. Fair, "The Conservative Basis for the formation of the National Government of 1931 ", in

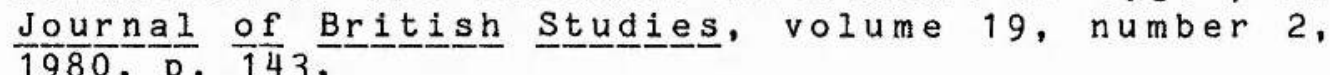


the August crisis they had put the national interest before party. In fact, although the Conservative party joined the national cabinet formed on 24 August 1931, and although that eventual decision was approved at the meetings of the party's representative institutions four days later, this outcome was not one which they welcomed or desired; indeed, it was simply accepted, first as the only solution to the crisis, and second as their patriotic 'duty'.

The Conservative party had not looked favourably upon the concept of a national government when that idea was occasionally floated in the press in 1930 and 1931 . Most of these suggestions came from figures, of a more or less maverick nature, mainly on the fringes of political life, and were not taken seriously by senior politicians. Too much significance can be put upon the pro-national propaganda of such figures as Sir Warden Chilcott, simply because the results of the crisis seemed to have endorsed their viewpoint. Chilcott, the most outspoken critic of the party system, had been a Conservative MP until 1929 , but carried no weight in British public life. Chilcott's analysis verged on the fascist, and the example of Mussolini was frequently cited by him with approbation. Such ideas had little appeal, and little seeming relevance, to the politics of winter 1930-1931, when they 


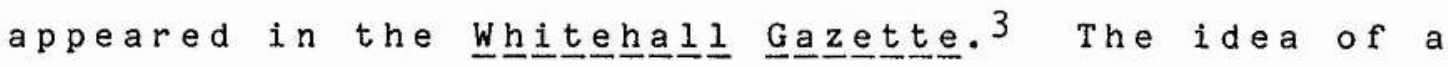
national government was periodically invoked by Garvin in the Observer during the same period, and taken up and echoed by the retired politician Lord Mottistone. ${ }^{4}$ None of these initiatives bore fruit, but taken together with the occasional suppositions and rumours then current about the position of MacDonald in particular, they required some reaction from the Conservative leaders. The rumours and hints concerning MacDonald were in fact the result of his characteristic method of relaxing by painting a dire picture of his position and difficulties in an appeal for the sympathy of his audience, who, as a result of the social circle MacDonald habituated, were frequently Conservatives or City figures who passed on his table talk to the Conservative leaders, believing themselves to have been selected as political go-betweens. The Conservative party's reaction to these public and private floatings of the national government idea was consistently and continually to dismiss it. Baldwin twice in December 1930 went out of his way in public speeches to discount the possibility. Party co-operation was ruled out because of the fundamental divides over the issue of protection versus free trade, and the only kind of party co-operation the Conservatives would consider would have to be on the

3. Whitehal 1 Gazette, December 1930; February, March, April 1931 ; reprinted in W. Chilcott, Political Salvation 1930-32.

4. Lane-Fox to Irwin, 3 December 1930, Halifax MSS, India Office, Eur. C. 152/19/1/180. 
basis of accepting the need for tariff reform. Between free traders and protectionists "there is a gulf that cannot be surmounted. Therefore, to talk of any kind of unity between us is ridiculous. From our point of view it is selling the pass". 5 This view only hardened during the following eight months as the movement of public and economic opinion away from traditional free trade accelerated visibly. Conservatives looked upon their own party as the embodiment of national unity, and believed that such unity was attainable not by their joining other parties, but by drawing into the Conservative ranks all those who sympathised with its outlook, seeing it as "the greatest unity of individuals in the country", comprising a complete political spectrum from left to right within itself, and this, Baldwin insisted, was the only basis upon which "we can form, and we hope to form, a national party". 6 This remained the public attitude of the Conservative party consistently through to the final pronouncements of party policy in July 1931. Thus, in his major speech at Hull on 17 July Baldwin dismissed the idea that a parallel situation existed with the wartime emergency of 1914-1918, declaring that a national coalition was neither "possible or necessary for the tasks of the present time", though he held out a hand to the Simon group of Liberal rebels who were moving closer to accepting the Conservative economic remedy.

5. The Times, 13 and 18 December 1930 .

6. Ibid., 18 December 1930 . 
Neville Chamberlain's reaction to apparent feelers from MacDonald relayed through stonehaven, the Conservative party chairman, in early July 1931 was inspired by the same appreciation of the idea of coalition. Stonehaven agreed that such a move would in fact split the Conservatives "from top to bottom", and Chamberlain dismissed it as "only an expression of [MacDonald's] weariness with an anxious and trying position", for if meant seriously he "must have got a long way off realities, for such a combination is clearly impossible."7 Chamberlain discussed the idea with Baldwin, and significantly both agreed "that our party would not stand it for a moment". 8 Thinking the matter over later in the month, Chamberlain sketched possible circumstances, which in fact were very close to those which occurred in August, in which he projected that

with perhaps a crisis in the City, unemployment soaring up to 3 millions, and the prospect of $k 100$ millions deficit in the Budget you might get a very powerful movement ... for a national government which would change the aspect very materially.

He considered that it would produce a Diehard right-wing revolt, and that the component sections of this national alliance would find they had little common ground. Chamberlain noted: "I myself hate the idea and hope it

7. N, to Ida Chamberlain, 11 July 1931, NC 18/1/747.

8. N. Chamberlain diary, 6 July 1931, NC $2 / 22$. 
won't come to pass." 9 There was at the end of July so much talk on the question of national government, however, that the Conservative leaders discussed the question; none wanted a coalition and all sought to avoid it, although it was realised that under the pressure of a crisis or a panic in the city it "might be very hard to refuse". 10 Baldwin had also been considering the tactics of such a possible dilemma in late July, and had requested advice from his colleagues. Steel-Maitland's reply clearly echoed Baldwin's own appreciation, and is worth quoting at some length ${ }^{11}$ :

The question you put to us was 'What did we think you should do if they ask you to join in forming a National Government under Ramsay MacDonald?' My own opinion is that you should refuse unhesitatingly, but offer to give them all support. The position is entirely unlike the war ..... I believe that joining a national government would mean entanglement with the Socialists and that it would be very difficult later to disengage. Bad in any case, it will be made infinitely worse by the presence of Lloyd George ....

If, however, you refuse to join a National Government under MacDonald - and I gather this is also you own view - it is necessary to consider what would happen next:

(1) The Government might carry on with the promise of your support .... The country would have learned the lesson that even a socialist Government must have sound finance ....

9. N. to Hilda Chamberlain, 18 May 1931, NC $1 / 1 / 748$.

10. N. Chamberlain, diary, 24 July 1931, NC 2/22; N. to Hilda Chamberlain, 2 August 1931, NC $18 / 1 / 750$.

11. Steel-Maitland to Baldwin, 28 July 1931, copy, SteelMaitland MSS, SRO.GD. 193/94/2, ff. 179-181. 
(2) They might decide to dissolve or resign ... result in either case - a general Election super-added [sic] to the crisis. I am sure you would win ....

(3) The pressure of public opinion to form a National Government might grow so strong that you would find it difficult, despite your own views, to persist in refusing .... In this event, I think you would stipulate... for a moratorium for ali measures other than those directly dealing with the crisis. When the crisis was surmounted... the party could disengage; an election would almost certainly follow, and you would come by your own.

This was to be almost the blueprint of Baldwin's strategy during the August crisis, as he was forced slowly from the first, to the second, and finally and reluctantly to the third, of Steel-Maitland's tactical alternatives.

Ironicaliy, as the crisis was about to break, the Conservative party leadership were strenuously endeavouring to encourage the 'friendly' press to dampen down the discussion of national government, after $\underline{T}$ e Times had again raised the spectre in its leader of 7 August. 12 Although August, as a holiday month, was normally almost devoid of political speech-making, those speeches which were given by prominent Conservatives, by Hailsham on 15 August and Ormisby-Gore at the height of the crisis on 20 August, both rejected the idea of national government, the latter declaring that his audience "could put out of their minds all idea of coalition or so-called National Govenment. Once bitten,

12. N. to Ida Chamberlain, 9 August 1931 , NC $18 / 1 / 751$; The Times, 7 August 1931. 
twice shy."13 Thus, though the idea of a national government had been in the air for over a year, on the very eve of the crisis it was rejected as a viable combination by all the leaders of the Conservative party. The reasons were simple and pragmatic, and far outweighed any dubious gains such an alliance might have brought. Electorally the party had nothing to gain from such a strategy, for it was clearly headed for a victory parallel to that of 1924, and a full term of office as majority single party. Also opposed were the Conservative party's instincts; the perennial one of avoiding all party splits, and the newer one dating from the events of 1918-1922, hostile to coalitions due to the belief that they necessarily involved compromising the purity of party principles. Hence the ruling out of any combination not based upon the common ground of the Conservative economic policy. Finally, the national peril, though acknowledged as considerable, did not have the immediate and urgent impact or seriousness of degree that it was believed to have developed by the end of August 1931 when it stampeded the Conservatives into actions not entirely of their own free choice. Their posture before the crisis unfolded requires to be outlined and underlined, because it is only in relation to this background that the steps which actually led to the formation of such a national ministry can be properly understood.

13. The Times, 17 and 21 August 1931. 
The financial crisis which broke in mid-August 1931 was the product of two distinct problems: a banking crisis which had its origins in central Europe and which had left the position of London exposed and vulnerable, and the budget deficit of one hundred and twenty million pounds for the financial year 1931-32 revealed by the report of the May Committee, published the day ater parliament rose for the summer recess, on 31 July 1931. Both of these factors combined to produce a serious run on the pound, and the situation could only be saved in the short term by propping up its parity through loans to be secured from financiers in Paris and New York. The experts of the Bank of England advised the government that these would not be forthcoming, unless the Labour cabinet set its house in order, and restored overseas confidence by showing its determination to balance the budget by reducing expenditure, in particular in the unemployment fund, the cause of much of the original imbalance. In other words, the crisis had become as much political as financial. It is not the concern of this thesis to discuss the debates and difficulties of the Labour government when faced with this problem, but only to examine the role of the Conservative party in the events surrounding the collapse of the second Labour government, and the formation of the national government; thus events are viewed entirely from the perspective of the Conservative party. In order to produce clarity into a complex series of events and influences, the phases of the 
crisis as they affected the Conservatives will first be narrated factually, and then analysed thematically.

In so far as it affected the Conservative party, the crisis of August 1931 occurred in four distinct phases. The first of these, from 11 to 13 August, began with the banking experts' request to MacDonald on 11 August that they be allowed to inform the leaders of the other two parties of the serious implications of the accelerating flight from the pound, to which the government agreed. As a result of the bankers' warnings, Baldwin was summoned back from his holiday in France, and Neville Chamberlain came down from his Perthshire retreat, both men arriving in London early on 13 August. At 10:30 they met Horne, one of the party's leading financial experts, who declared that "the only thing that could restore confidence would be a determined effort by the Government to put its house in order". 14 Baldwin took Chamberlain with him to his interview with MacDonald and Snowden, the Chancellor of the Exchequer, at 10 Downing Street at 2:00 p.m. The government leaders wanted to secure opposition approval for their proposals to balance the budget, as they could not rely upon all their own MPs for such a vote, and thus they proposed to ask both Conservatives and Liberals to approve their proposals, which they hoped to have ready on 18 August. At this preliminary stage, Chamberlain asked if the total amount of the deficit to be met by economies 14. Memo, 'The Financial Crisis', N. to A. Chamberlain, 14 August 1931, AC 39/3/26, hereafter referred to as 'The Financial Crisis'. 
would equal the May Committee's recommendation of ninetysix and a half million pounds, and snowden, warning that the deficit was even larger than May had predicted, agreed this point. Chamberlain declared this amount to be "adequate" but went on to say that "what might be much more difficult for us was approval of the proposals for new taxation", and it became clear that, on the doctrine of equality of sacrifice from all sections of the community, approval would be sought for the complete government package. ${ }^{15}$ No conclusions were arrived at in this exploratory phase, but MacDonald indicated that "if he could obtain our general support he would call parliament together in the first fortnight of september to pass (1) a supplementary budget (2) an Economy Bill."16 Immediately after this interview, the two Conservative leaders met the Bank of England officials, who shook them further by warning that "the situation could not be more serious". ${ }^{17}$ After this Baldwin, sensing perhaps instinctively that the party's position would become difficult if it became too involved in the crisis, devolved the responsibility for meeting the government in

15. Loc. cit.; N. Chamberlain, diary, 22 August 1931, NC $2 / 22$.

16. 'The Financial Crisis'; N. to Hilda Chamberlain, 16 August 1931, NC $18 / 1 / 752$.

17. N. Chamberlain diary, 22 August 1931, NC $2 / 22$. 
the next week to Neville Chamberlain, giving him a watching brief. Baldwin's attitude was to "get away as soon as ever possible lest I should be drawn into something". 18 The mood of the party after this first phase was clearly against too close an involvement in the government's problems. Neville Chamberlain assured Gwynne that there was "no suggestion of a National Government" and that they were only asked for "our general support", and he evidently expected the ministry to survive the crisis.19 The Conservatives sited their defensive position, as they had foreshadowed, around their distinctive policy of the emergency tariff. Horne urged this on Baldwin on 15 August, and on the same day the party leader instructed Neville Chamberlain to bring it forward at the meeting with the government ministers the next week, as a tactic to distance the Conservatives from Labour and their Liberal allies, whom Baldwin held jointly responsible for the overspending, and who thus should be responsible for solving the crisis. 20 Baldwin's fears of being entrapped were echoed by Bridgeman, who advised forcing acceptance of the tariff in view of the fact that

18. 'The Financial Crisis'.

19. N. Chamberlain to Gwynne, 13 August 1931, Gwynne MSS 17; to Cunliffe-Lister, 15 August 1931, Swinton MSS, SWIN I (174) $2 / 1 / \mathrm{ff}$. $11-12$.

20. Horne to Baldwin, 15 August 1931, Baldwin MSS, volume 44, ff. 22-24; Horne to N. Chamberlain, 15 August 1931 , copy, ibid., ff. 25-34; Baldwin to $N$. Chamberlain, 15 August 1931, NC $7 / 11 / 24 / 1$. 
the Conservative party "have the strongest hand" and "must not be prevented from taking advantage of it". 21 This paralleled Neville Chamberlain's projection of the probable results of the crisis, a dissolution and election "in conditions offering us the utmost advantage" in which the party would "concentrate on tariffs and imperial preference as the restorers of prosperity".22 At the end of this first phase Baldwin crossed again to France, and Chamberlain temporarily returned to Scotland.

The second stage opened on Thursday, 20 August, and lasted until the agreement on a path of action to be followed by the Labour cabinet appeared to have been successfully concluded on 22 August. MacDonald and Snowden had been unable to draw up their proposals for a meeting on 18 August, as previously proposed, and postponed the three-party conference until 20 August. With Baldwin away, Neville Chamberlain asked Sir Samuel Hoare to accompany him to the meeting for the Conservatives; Sir Herbert Samuel and Sir Donald MacLean represented the Liberals, and the Prime Minister and the Chancellor the government. Snowden put before the opposition leaders plans for economies of seventy-eight and a half million pounds, which at first chamberlain thought "was not too bad", until snowden revealed that the budget deficit was now projected as one hundred and 21. Bridgeman to Baldwin, 16 August 1931, Baldwin MSS, volume 44 , ff. $35-38$.

22. N. to Hilda Chamberlain, 16 August 1931, NC 18/1/752. 
seventy million pounds - with the implication that the remaining figure of over ninety million pounds would have to be found by new taxation.23 In light of this Chamberlain reverted to his original proposition that the economies must be the larger part, not less than the ninety-six million recommended by May, and must include more than merely cosmetic cuts in the unemployment allocation. MacDonald and Snowden indicated sympathy with this line, and sought to use this stand of the opposition as a lever with which to return to the Labour cabinet and pressurise it into accepting a higher figure as the price of political survival; they arranged to see the opposition parties again after the cabinet had discussed the matter further. 24 After this three-party meeting, later on 20 August, Chamberlain and Hoare had three further meetings. The first was with the bankers, "who were very pleased with the stand we had taken", 25 but who "at the same time impressed on us that the sands were rapidly running out". 26 The second meeting was with other members of the Conservative front bench then available in London: Hailsham, Cunliffe-Lister, Kingsley Wood, and the chief

23. N. Chamberlain, diary, 22 August 1931, NC $2 / 22$.

24. Loc. cit.; N. to Ida Chamberlain, 23 August 1931, NC $18 / 1 / 753$.

25. N. to Anne Chamberlain, 21 August 1931, NC $1 / 26 / 446$.

26. N. Chamberlain diary, 22 August 1931, NC $2 / 22$. 
whip, Eyres-Monsell, all of whom agreed with Chamberlain "that retrenchment was the vital thing". 27 The third and final meeting was an impromtu rendezvous with the two Liberal leaders, who "agreed generally with our view" on the scale of the economies, though they considered that eighty-five million pounds, as half of the one hundred and seventy million deficit, would be acceptable.28

At 3:00 p.m. on the next day, 21 August, the four opposition representatives were summoned back to Downing Street to meet Snowden and MacDonald again, and to be told that the cabinet would only swallow economies of fifty-six million pounds. MacDonald in weary disillusion seemed to wash his hands of the responsibility; it was all he could get, and if it did not restore confidence then the result would be "the deluge". For the Conservatives, Hoare vigorously protested at both the small amount of the economies and MacDonald's conception of his responsibilities as national leader, and in reply MacDonald made his famous remark, delivered "in a semijocular way, 'Well, are you prepared to join the Board of Directors?', to which [Hoare] replied that if seriously made that was a proposition which would demand serious consideration."29 This comment has been much over-rated and misunderstood, for it was the throwaway retort of a

27. N. to Anne Chamberlain, 21 August 1931, NC $1 / 26 / 446$.

28. N. Chamberlain diary, 22 August 1931, NC 2/22.

29. Loc. cit. 
weary man at his wits' end. More importantly, Hoare's response was not one of approval, but a classic politicians' manoeuvre to evade commitment on a question where it is difficult to refuse point blank, and his reply, far from opening up the topic, quite clearly ended all discussion of such an eventuality at that time. Far from coalescing with MacDonald, the two opposition groups withdrew to an upper room at Number 10 to consult each other, and the conclusions they drew were that first, a crash must be avoided at all costs; second, that the government must face up to their responsibilities; and third, that the way to make them do so was by threatening to oust them - not by any offer of a helping hand. 30 After leaving Downing Street once again to inform their waiting Conservative colleagues of events, Chamberlain and Hoare returned to the second three-party meeting of that day, at $9: 30 \mathrm{p.m}$. Here the strategy earlier agreed with the Liberals of threatening the government was put into effect. Nothing was said on the topic of a national government, but in fact the Conservative position had begun to change under the pressure of the seriousness of the crisis, and they no longer completely excluded the possibility. MacDonald, after a lengthy digression on his own position, determined to try to carry his cabinet once again the next day. As the four opposition politicians were about to leave Number 10 that evening, the two 30. Loc. cit. 
Liberals were summoned back for a private session with MacDonald, and indeed it was the Liberals, the former unofficial allies of the government, and not the Conservatives, who were on the inside track with the Labour leaders. Chamberlain and Hoare thus departed alone, to another meeting with their colleagues and with Harvey, Deputy Governor of the Bank of England.

At the next meeting of the party leaders, at 12:30 p.m. on Saturday, 23 August, a solution to the crisis appeared to be at hand. This was not any sort of coalition, but a proposal from MacDonald to suggest economies of sixty-eight and a half million pounds which included a ten per cent cut in dole benefits, and to save a further fifty million pounds through suspending the payment to the Sinking Fund for the National Debt. The Conservatives agreed to this on two provisos: firstiy, and obviously, that the cabinet accept this plan; and secondly, and more importantly, that the bankers approve the economies as sufficient for their purposes; and that in this event if "the $60 \mathrm{~m}$ cut would enable them to get the money, we were not going to be 'more Royalist than the King', and on that ground our difficulties would be at an end".31 Neville Chamberlain believed that the financial and political problems had both been resolved, and he continued to think so until 3:00 p.m. on the following day, August 23, interpreting the fact that MacDonald was to see the King that day as merely "part of Ramsay's game 31. Loc. cit., second entry for 22 August 1931. 
game to put pressure on his Cabinet. My belief is that they will accept" and thus "the crisis is over and I should be able to go north tomorrow".32 However, the solution arrived at by the end of this second stage collapsed due to MacDonald's inability to win his cabinet for economies which included a cut in unemployment benefits.

The third stage of the drama opened on sunday 23 August with the return to London of the two principal actors in the events which led to the formation of the National Cabinet, respectively Baldwin, who arrived in the evening of 22 August, and King George V, who returned at $8: 00 \mathrm{a} . \mathrm{m}$. On the morning of 23 August. At $10: 30$ the King saw MacDonald, who informed him that as several of his cabinet were resigning it was impossible for him to carry on, and so he advised the king to see the leaders of the other two parties, Baldwin for the Conservatives, and Samuel, acting leader of the Liberal party whilst Lloyd George was in hospital. Meanwhile, Baldwin had gone to see his advisor and friend Dawson, the editor of The Iímes, and lunched with him at the Travellers Club, discussing the crisis. Dawson advocated supporting Labour in carrying out the economies, and to this Baldwin agreed, although it was clear that he thought it more likely that the Labour cabinet would dissolve and that he would be sent for to construct a Conservative administration, and

32. N. to Anne Chamberlain, 3:00 p.m. 23 August 1931, NC $1 / 26 / 447$. 
they discussed its personnel.33 As a result of being unable to trace Baldwin immediately, the King's private secretary summoned Samuel to the Palace first, where he saw the king at noon, and strongly reinforced his disposition to favour the idea of a national government. 34 It was as a consequence of this that when Baldwin was admitted to the royal presence at 3:00 p.m. that afternoon, the king opened the interview by asking him outright if he would serve under MacDonald in a crisis national ministry - a request which Baldwin could hardly refuse. He considered this promise unlikely to be taken up, for the King then told him that, though MacDonald was to make one last effort with his cabinet that evening, if he failed Baldwin would be sent for next day to receive the royal commission to form a ministry. 35 After leaving the Palace on the afternoon of 23 August Baldwin conveyed this news to Neville Chamberlain, and they debated their strategy. Chamberlain urged that as, due to the parliamentary balance of power, Baldwin would have to make some offer to the Liberal leaders to join him, and thus could no longer hope to construct a purely Conservative government, he should also try to get MacDonald and

33. Memo, 'Events of Sunday 23rd August', Dawson MSS.

34. Memo by Wigram in RAK 2330, quoted in H. Nicolson, King George V $(1952)$, p. 461 .

35. Loc. cit.; N. to Anne Chamberlain, 23 August 1931, NC $1 / 26 / 447$. 
Snowden to serve under him; Baldwin reluctantly accepted these constraints and agreed with Chamberlain's idea. 36

on the evening of Sunday 23 August the Labour government held its last cabinet meeting, breaking up at 10:00 p.m. With the refusal of almost half the cabinet to accept the economy proposals, and MacDonald left at once for Buckingham Palace, declaring he was going to throw in his hand. However, the king persuaded him to sleep on it, and, more importantly, told him first that "he was the only man to lead the country through this crisis" and asked him to "reconsider the situation", and second "His Majesty told him that the Conservatives and the Liberals would support him in restoring ... the financial stability of the country".37 In reply to this MacDonald asked the King to preside next morning over a meeting of the leaders of the three political parties, to which the King readily assented. On his return to Downing street MacDonald summoned the Conservative and Liberal leaders to see him at 11:00 p.m. on the night of 23 August. MacDonald then told them that "he could not go on ... and had told the king so", and that "it would be of no use for him to join a government". It was at this late stage, and in the context of his discussion with Baldwin that afternoon, that Chamberlain made his appeal to MacDonald to

36. N. Chamberlain diary, 23 August 1931, NC $2 / 22$.

37. Wigram's memo of audience of 23 August 1931, RAK 2330, Nicolson, op. cit., p. 464. 
reconsider the latter part of his decision, and give support not from outside, but within, the new government. Though Samuel supported this plea, Baldwin "maintained silence and we did not pursue the matter further".38 Thus were matters left at the end of the third stage of the crisis, at midnight on 23 August, with MacDonald expected next day to withdraw, and Baldwin to be invited at the meeting arranged at the Palace to form a government, a government which MacDonald was thought unlikely to join. 39 Dawson at The $\underline{\text { Times }}$ e had written the next day's leader column "on the assumption that he had handed the baby to Baldwin". 40

The fourth and final stage, the events of Monday 24 August, produced the unexpected reversal of this position, and directly produced the national government formed on that day. That outcome, it must be emphasised, was not anticipated or specifically sought by the Conservative leaders at any stage of the crisis. At the meeting of MacDonald, Samuel and Baldwin at 10:00 a.m. that morning at Buckingham Palace it had been the King who had both opened the discussion and dominated events by setting the tone for a national ministry, specifically saying "that he trusted that there was no question of the Prime Minister's 38. N. Chamberlain diary, 23 August $1931, \mathrm{NC} 2 / 22$; N. to Anne Chamberlain, 24 August 1931, NC $1 / 26 / 448$.

39. Cunliffe-Lister to his wife, 24 August 1931, Swinton MSS, SWIN III (313) $1 / 5$.

40. Dawson to Astor, 25 August 1931, Dawson MSS. 
resignation" and hoping he would form a national government "supported by the Conservatives and the Liberals". The King also placed the three politicians under the considerable pressures of his own prestige, and of time, insisting that a decision be hammered out there and then at the Palace for immediate release to the press. Having for over half an hour put the case for a national government, and gained agreement from Samuel and - with his promise of the previous day fresh in his memory - from Baldwin to serve under MacDonald, the King withdrew, leaving the three only "to settle the details". 41 MacDonald was swayed and flattered into reversing his decision of the previous night, and Baldwin was left without any respectable opportunity to block a national coalition, and thus the decision to form a national government was taken.

The 'details' were then settled in a six-point memorandum:

(1) National Government to be formed to deal with the present financial emergency.

(2) It will not be a Coalition in the ordinary sense of the term, but co-operation of individuals.

(3) When the emergency is dealt with, the Government's work will have finished and the Parties will return to their ordinary position.

(4) The economies and [new taxation] shall be equitable ....

41. Wigram's memo of Buckingham Palace conference, 24 August 1931, RAK 2330, op. cit., Nicolson, pp. 465466 . 
(5) [legislation other than routine would not be proposed]

(6) The Cabinet shall be reduced to a minimum.

Many of the key provisions of this document reflected Baldwin's reluctance, and were included above all to satisfy the demands of the Conservative party, rather than of the other parties. In particular two statements, that it was not a coalition and that the government was only to deal with the financial crisis after which the parties would resume their respective positions, were clearly aimed at assuaging Conservative anxieties. The former referred to the experience of the Lloyd George coalition, and the latter offered reassurance that the tariff policy had not been abandoned, but only suspended temporarily. The new cabinet of ten, with six free traders (four Labour and two Liberals) and four protectionists, could hardly be considered a favourable arrangement for the party committed to the emergency tariff. However, under the combined pressures of the parliamentary position, the royal pressure for national unity, and the bankers' clamour that national ruin was only hours away, the Conservative leaders more or less reluctantly acquiesced in a fait accompli. 43

42. Memorandum, quoted in full in H. Berkeley, The Myth That Will Not Die (1978), pp. 90-91.

43. N. Chamberlain diary, 24 August 1931, NC 2/22; A. to Ivy Chamberlain, 24 August 1931, AC 6/1/800; Cunliffe-Lister to his wife, 24 August 1931, Swinton MSS; Page-Croft's speech, The Times, 29 August 1931. 
The attitude of the Conservative leadership to the question of participation in a national government appeared to have been transformed by the events of August 1931. In fact this was more apparent than real, for many of the party's considerations and aims had remained consistent, although the means of reaching these ends had evolved by 24 August to include the possibility - but not necessarily the desirability - of a coalition. The process by which this occurred has been narrated, but analysis of the principal factors affecting the conduct of the Conservative party reveals a number of crucially significant themes explaining the actions taken and options chosen by them. One of the most important pressures upon the Conservatives had been the combination of the sudden eruption of the crisis, and the crucial pressure of apparently having only hours in which to stave off national catastrophe. During July the Conservatives had been proceeding slowly with their strategy of seeking alliance with the Simonite Liberals in the Commons on the basis of acceptance of protection, in order to defeat the government in October, and as late as 10 August one Conservative MP told his constituency executive that "he saw no prospects of a sudden election" or change of ministry. 44 These plans and assumptions were "overtaken by the dramatic and overwhelming march of events in the

44. Maidstone CA, Exec., 10 August 1931. 
autumn of 1931".45 As Bridgeman commented, "the August crisis was very sudden", catching the party during the holiday period, and taking even its financial experts unawares by the suddenness of its eruption. As Neville Chamberlain wrote on 16 August, "things suddenly boiled up in the City". 46 Added to this was the pressure of time, as the fact that it was, in The Tímes words, "a matter of hours" was widely accepted, and changed the attitude of some Conservatives, such as Davidson, on the expediency of co-operation. 47 The firm ruling out of coalition was thus eroded, partly also as a result of the fact that a new common ground had emerged between the parties - one more important than tariff reform - the question of economy. As a result, in view of the emergency, the party could without sacrifice of principle unite for this purpose only with other parties. The consensus could only be temporary, for once the economies were achieved, the tariff question would again come to the forefront of Conservative politics. To have reached such a position, whereby late on 21 August national government was no longer being excluded, was certainly a change in the party's position, but it was not indicative of any desire for such a government - only the dawning realisation that the pressure of time and circumstances might force it on, 45. James, ed., op. cit., pp. 373-373.

46. Bridgeman journal, August 1931, volume II, p. 237; N. to Hilda Chamberlain, 16 August 1931, NC 18/1/752.

47. The Times leader, 21 August 1931; James, ed. op. cit., pp. 365-367. 
especially as parliament was not in session. On 24 August Austen Chamberlain acknowledged that "it has been perhaps still is - a question of hours between this country and 'the deluge'". 48

In this belief, and in all their other consequent actions and choices, the Conservative leaders were dominated by their unquestioned belief in, and support of, the position of the bankers and of the City. Horne spoke for the City when placing the situation before Baldwin, and in particular in directing attention to the need for economies on unemployment. 49 In the same way, Neville Chamberlain had at the end of the parliamentary session in July held his fire in an economy debate, and passed up the chance of party advantage, due to the anxiety of the City lest he should paint too strong a picture. 50 Indeed, it was as a result of the bankers'initiative that Chamberlain and Baldwin were requested to return to London and became involved in the first place. 51 From that point the party came close to being the echo of the city, and it comes as no surprise that the financiers approved of their conduct on 20 August, and were involved in the consultations of the party's leaders on the following day. 48. A. to Ivy Chamberlain, 3:00 p.m. 24 August 1931, AC $6 / 1 / 800$.

49. Horne to Baldwin, 15 August 1931, Balwin MSS, volume 44, ff. $22-24$.

50. N. to Hilda Chamberlain, 2 August 1931, NC 18/1/750.

51. Lloyd to Cunliffe-Lister, 14 August 1931, Swinton MSS, SWIN I (174), $2 / 1 /$ f. 26 . 
The role of the bankers was not the sinister one of attempting to destroy the Labour government; it was nothing so subtle. The bankers were desperately anxious over their own professional arena of finance, and were simply seeking to impress upon all parties the gravity of that position in order to arrive at some solution. Thus the Conservatives were willing to follow their guidelines in the matter of the amount of economies required, and in muting their hostility to new taxation, and of a piece with this was their acceptance also of the bankers' declaration of 22 August that financially they could only hold out for four days. One consequence of this was that all other possible solutions to the crisis, several of them more attractive to the party grassroots, were ruled out. Amery questioned the need for immediate action, and the wisdom of placing economy before protection, declaring that "in these matters I think we are all too inclined to take the bankers at their word". 52 Against the policy of deflation Amery set the alternative of a high wages policy as a result of vigorous empire development.53 Another possibility was pointed out by Beaverbrook, a figure whose views carried some weight, not just for his recent involvement in Conservative politics, but also as

52. Amery to Gwynne, 8 September 1931, Gwynne MSS 14; Amery diary in L. S. Amery, My Political Life(1955), volume III, pp. 61-62.

53. Amery to Beaverbrook, 26 August 1931, Beaverbrook MSS, C6. 
an able and successful financier in his own right - that the simple fact of the accession to offlce of a Conservative government would have been enough to restore confidence and secure the loans.54 The final choice was also ruled out by the bankers: the idea, first raised by Neville Chamberlain, for a capital levy which would be used to reduce the national debt, and thereby removing the need for one hundred million pounds per annum in debt charges. The disapproval of the bankers when this idea was put to them, partly because they feared that it would cause a flight from the pound, was so strong that Chamberlain swiftly dropped the idea. 55

The large-scale economies desired by both the financial interests and the Conservative party were not without their political complications: first, in the question of the role of new taxation in making up the deficit remaining, and second in the matter of their possible electoral unpopularity. Economies on the scale sought were accepted as impossible without being matched by some new taxation, but it was the concern of both City and party to keep the latter at a minimum and the former at a maximum. For this purpose the Conservatives insisted upon the doctrine of equality of sacrifice, and it was established at the very first meeting with MacDonald and Snowden on 13 August that the budget must be balanced in 54. Lockhart diary, 31 August 1931.

55. N. Chamberlain diary, 27 August, 3 September 1931, NC $2 / 22$. 
accordance with this principle. This was the only method by which the Labour leaders could be committed to the principle that economies should provide at least half the required amount. The crucial point is that the Conservatives were more concerned with the avoidance of further burdens of taxation, and thus placed the emphasis on the role of economy. The doctrine of equality of sacrifice was not a magnanimous gesture on the part of the better off to share the burdens of the financial crisis in the same sense as was the later gesture of the royal family to cut one hundred thousand pounds from the Civil List. On the contrary, it was designed for the reverse purpose. In part it was a consequence of fears that a Labour government would be tempted to revert to a soakthe-rich 'people's budget'. This was considered a danger for three reasons: the first was the instinct of selfpreservation in that it would hit hardest the Conservative interest groups; the second was the genuinely held belief in these circles that the slump was due to over-burdening local and national taxation, sapping domestic confidence and investment; and third, the related fact that, as the overseas bankers held the same economic world-view, that the needed loans would not be forthooming if a hightaxation policy was adopted. As both Horne and Chamberlain declared, it was not simply a question of somehow wiping off the deficit; the budget had to be 
balanced in the right way.56 Equality of sacrifice was in fact designed to ensure that the government could not meet their target without a real cut in the unemployment benefit, and that the unemployed could not be considered as a special case immune from the financial debacle. Thus it was as much a political doctrine as a financial one. It was for this reason that Chamberlain strove to preserve the freedom of action of his party in the matter of approving proposals for new taxation in the agreement concluded at the mid-day meeting on 22 August, which he believed had resolved the crisis. This was the explanation of his willingness to approve a plan which, whilst committing the Labour government to proposing real economies when parliament reconvened, left the Conservatives free to propose and carry with Liberal support amendments both to increase the economies and Iimit the new taxation. It was not a subtle ploy to split the Labour party, but a determined effort to simply minimise the 'burden' of new direct taxation. 57 once MacDonald and Snowden had accepted these principles, it

56. N. Chamberlain diary, 22 August 1931, NC 2/22; Horne to N. Chamberlain, 15 August 1931, copy, Baldwin MSS, volume 44, ff. 25-34; speech of Ormesby-Gore, The Iimes, 21 August 1931; Middleton to Salisbury, $\frac{19}{19}$ August 1931, Salisbury MSS, S(4) $141 / 142$.

57. N. Chamberlain diary, 22 August 1931, NC 2/22, Chamberlain ascertained that once the House was in Committee on the proposed Economy Bill an amendment to increase the dole cut from ten per cent to twenty per cent would be treated by the government as a matter for resignation; but this was not his concern, and by implication a simple reduction of direct taxation amendment would not be taken as an issue of confidence. 
increasingly became a vested interest on the part of Conservatives to maintain in office these Labour figures, as their conceptions of a fiscal policy were increasingly coming to coincide. The final solution arrived at, although it had involved accepting the continuation of MacDonald as Prime Minister, was economically acceptable to Conservatism. The amount raised by taxation could be kept to a minimum, and in addition with the changed attitude both of Labour figures such as MacDonald and Thomas, and of Liberals such as Simon and Runciman, to the concept of the revenue tariff, there was a good prospect that such taxation as had to be imposed would be indirect duties, not income tax or super-tax increases.

Having thus got the key Labour figures of Snowden and MacDonald to face the need for economies, the logical consequence was to seek to involve them prominently in the passing of these measures. 58 This was reinforced by the considerable anxieties felt by Conservative politicians over the possible electoral unpopularity of such measures if passed by an 'upper class' government, as opposed to the reception of proposals which had the approval of the leaders of Labour opinion.59 The scenario Conservatives feared was that if they alone attempted to impose economies before a dissolution of parliament, they would 58. Cunliffe-Lister to his wife, 24 August 1931, Swinton MSS, SWIN III (313) 1/5; memo, 'Events of Sunday August 23 rd', Dawson MSS.

59. Dawson to Salisbury, 5 September 1931, Salisbury MSS S(4) 141/64; A. to Ivy Chamberlain, 24 August 1931, AC $6 / 1 / 800$. 
make themselves vulnerable. 60

Having appeased the demands of supporters who had pressed for economy, the party could find itself left alone to withstand the electoral backlash from the victims of those same economies. Instead of being in opposition attacking a weak and discredited government, the safe harbour of opposition would have been relinquished to Labour, and as a result the Conservatives might end up actually losing an election they had seemed destined to win. This fear was not completely allayed by the formation of the national cabinet, although it was a good argument for retaining MacDonald and Snowden in their present offices, and this anxiety was not completely laid to rest until public opinion had been established by the general election in october 1931. It was a particular anxiety of those who placed tariffs before economies, but it also seriously worried Conservative prospective candidates for the northern constituencies where unemployment was at its highest levels.61 The election eventually demonstrated that popular reaction to the national government had not developed along these lines, but that does not negate the fact that this scenario exercised the minds of Conservative strategists in Iate August. The rationale behind the desire to involve some

60. Bridgeman to Baldwin, 16 August 1931, Baldwin MSS, volume 44, ff. 35-38; Hilton Young to his wife, 24 August 1931, Kennet MSS $107 / 3$.

61. Amery to Beaverbrook, 26 August 1931, Beaverbrook MSS, C6; Beaverbrook to Elliott, 6 September 1931, ibid., C129; Headlam diary, 24 August 1931. 
Labour figures in the new government under Baldwin - which had been expected until the last moment to be the most logical development - was not principally a Machivellian ploy to split the Labour party, but was a simpler device to spread the load of unpopularity on as many nonConservative shoulders as possible. It was, perhaps, only a short step from this attitude to accepting that if the premiership was the only post MacDonald would take, that this was not, after all, too high a price in the short term. 62 No one expected the new government, and therefore MacDonald's continued presence at No. 10, to be other than a temporary expedient.

The Conservative party sacrificed much in the short term tactical dimension, and endangered much in the long term electoral dimension, by its actions during the crisis of August 1931. Where it gained, it gained in policy though in only one half of its policy, economies but not tariffs, but at least in the foremost element. This gain in the fiscal sphere was the prize for which the Conservative party joined the national government. In one sense, especially in view of its acceptance of the bankers' views on the urgency of the position, and therefore of the limitations to its freedom of action, being forced to act hastily with parliament adjourned, it could almost be argued that the Conservative party were more than any other party the victim of a bankers' 62. Cunliffe-Lister to his wife, 21 August 1931, Swinton MSS, SWIN III (313) $1 / 5$. 
'ramp', albeit a genuine one. Neville Chamberlain's favouring of the idea of a Labour presence in the new administration reflected not his political sophistication, but his connection with, and greater responsiveness to, City opinion. To suggest that any Conservatives were principally motivated during the August crisis by cunning notions of destroying the Labour party is patently absurd, not least because they clearly recognised that MacDonald and Snowden would attract very few followers from the Labour party, although they might have some standing in the country. The Conservative leaders were worried and anxious men themselves, concerned primarily with two things, the situation of the pound and the relationship thereto of the economy proposals, against which was balanced the desire to avoid increases in direct taxation. At that altar they risked sacrificing the political interests of their. own party as much as any other, although they did so partiy in keeping with their accepted notions of patriotism and duty. Any damaging side effects on the Labour party only came into the picture as an added bonus to the principal concern. Joining a national government was not the gain made by Conservatives in August 1931 but it was the means to achieving the end they sought: a reversal of the trends in the spheres of government expenditure and bureaucracy, of the role of government social action, and of direct taxation, both national and local. Thus, at the height of 
the crisis on 21 August, the party leaders agreed "that retrenchment was the vital thing and that we must ... concentrate entirely on that". 63

The role of Neville Chamberlain in the crisis has been categorised as that of being the architect of the national government, who "checkmated MacDonald and made certain the Labour Party's fall from power", who had "foreseen every contingency", and who was "clearly in command of the situation".64 The latter Chamberlain was not; he acted in an advisory capacity to Baldwin, and was not present at the two crucial audiences at Buckingham Palace on 23 and 24 August, at which the situation had been completely transformed. During Baldwin's absence his position had been that of observer, not of executive, and as soon as matters became serious he both sent for his leader and called his colleagues into consultation with him. 65 Such decisions as were taken to join a coalition ministry were taken initially by Baldwin, and then approved by the collective party leadership. The casting of Chamberlain as planner of the national government is also inherently unsatisfactory because it is based on the dubious assumption that of all the politicians only Neville Chamberlain was unaffected by the panic of the crisis, the pressures and alarms of the city, and the

63. N. to Anne Chamberlain, 21 August 1931, NC $1 / 26 / 446$. 64. Fair, op. cit., p. 154 .

65. Lloyd to Cunliffe-Lister, 14 August 1931, Swinton MSS, SWIN I (174) $2 / 1$, ff. $26-28$. 
atmosphere of the sacrifice of party interest for the sake of national interest. It was not Chamberlain's appeals which 'seduced' MacDonald into joining the national government, for, although they were not completely without effect, they were a minor contributory factor. MacDonald was aware of Chamberlain as a highly partisan Conservative, and was too experienced a politician to accept his advice as disinterested, and he was even less likely to be moved by an appeal that was visibly not supported by Chamberlain's leader, a man for whom he had much more liking and respect. It was in fact the king who carried enough weight, and yet was believed to be acting purely in the 'national interest', who both urged MacDonald to remain as premier and Baldwin to serve under him; no one else had the prestige or respect which would have been necessary to sway either politician into such a course of action.

Chamberlain was concerned with the financial position much more than with the political one. 66 on 20 August he told Hoare that the essential problem they had to face "was to restore foreign confidence in British credit", which would only be achieved by such a cut in annual expenditure that would show "we had sufficient courage to tackle the situation". 67 Chamberlain had nailed his flag

66. The press statement released by Chamberlain after the meeting of 13 August was entirely concerned with the financial position; for example, The Times, 14 August 1931 .

67. N. Chamberlain diary, 22 August 1931, NC $2 / 22$. 
to the economy mast during the previous year, and now felt that

to secure such a measure of relief and to do it through a socialist government seems to me so important in the national interest that we MUST give it our support, provided the proposals for 'equal sacrifice' do not imperil British credit or brazenly affront ordinary rules of justice.

In the latter sense he was aware that "the danger from our point of view is the 'sacrifice' by the Rentier". ${ }^{69}$ If, however, the government "do mean business at last" and will "face the issue", Chamberlain wrote that "in such circumstances our duty seems to me plain enough. We must give the assurances [of support] and hope that we shall not as a party suffer for it". 70 Chamberlain sought to associate Labour with the economies in order to increase the chances of their acceptance, and his early moves were designed to aid MacDonald in carrying his cabinet for a larger sum. The Conservative position tactically evolved on a day-to-day basis, but it was always founded upon these aims. Thus, Neville Chamberlain's urgings to MacDonald late at night on 23 August in reality represented the final fling of his favoured plan that the Labour government should accept responsibility for their 68. N. to Hilda Chamberlain, 16 August 1931, NC 18/1/752.

69. Lloyd to Cunliffe-Lister, 14 August 1931, Swinton MSS, SWIN I (174) $2 / 1$, ff. $26-28$.

70. Memo 'The Financial Crisis', N. to A. Chamberlain, 14 August 1931, AC $39 / 3 / 26$. 
own overspending. This last-minute idea appeared the only way left, after the Labour cabinet had broken up only two hours before, to get some kind of Labour involvement with the dole cuts, and it should not be misread as part of a strategy for a national government. Chamberlain came to favour a temporary all-party coalition, not for its impact on domestic politics, but in part for the very reason he gave MacDonald - that his name carried weight overseas and his presence would increase the chances of restoring overseas confidence. ${ }^{71}$ Chamberlain's ideas become even clearer by the evidence of the one occasion when he did appear to consider the political consequences of his policy in the party context. At the meeting of 12:30 on 22 August he toyed with the adoption of a partisan role by the Conservative party - but through the medium of remaining as uncommitted as possible, not by entering into coalitions. Looking back on an arrangement which on 22 August he believed had resolved the crisis, Chamberlain detected as a by-product of the plan for Labour to meet parliament with their economy proposals for discussion in the Commons that "we have got the Govt. into a most difficult position and by concentrating on economy have preserved our rights on taxation completely".72 This idea swiftly fell by the wayside, not just because the Labour cabinet disintegrated, but because the bankers made

71. N. Chamberlain diary, 23 August 1931, NC $2 / 22$.

72. N. to Anne Chamberlain, 23 August 1931, NC $1 / 26 / 447$. 
it clear that the constraints of time would not permit such a delayed resolution to the crisis. The incident demonstrated, however, that what partisan instincts Chamberlain had were to keep a weak Labour government in office and to retain the safe ground of opposition, until the anticipated dissolution.

Baldwin's views paralleled these, and he was even more hostile to the idea of becoming involved in another coalition.73 In the first phase of the crisis his demeanour was "bouncy" as he thought the government about to collapse, and expected to replace MacDonald as Prime Minister at any moment, and indeed as late as the evening of 23 August he was planning the composition of his intended cabinet.74 It was because he feared that involvement might prevent this outcome that he sought to distance himself; despite his endeavours, however, coalition became inescapable. In part this was because Baldwin, too, accepted the bankers' view of both the seriousness and urgency of the crisis, and of the solution required. Nevertheless, as he arrived at Buckingham Palace at 10:00 a.m. on $24 \mathrm{August}$, he expected to become the next Prime Minister, even if his government was not to be purely Conservative. The fact that he did not do so was because he gave in, though with reluctance, to the

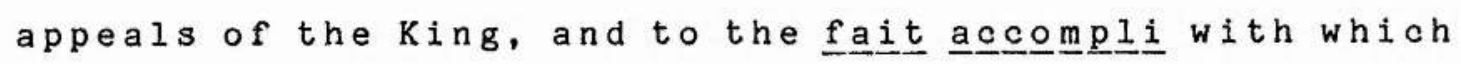
73. James, ed., op. cit., p. 367 .

74. Balwin's speech at Kingsway Hall, 28 August 1931, The Times, 29 August 1931. 
he was presented by the fact that, at George V's persuasion, not only had MacDonald not resigned, but that he was now willing to remain and lead a national government. Given that both the king and Samuel - who controlled the balance with the Liberal MPs in the House were keen to support this idea, and given the hypothetical promise Baldwin had made the previous day - and he was not a man to break pledges, especially those given to his King - and given the attitude of the City that hours were of vital concern, so Baldwin had lost that tactical freedom of manoeuvre which by disengagement he had throughout the crisis tried to maintain. 75 Despite all the press talk of national government during the previous twelve months, it was not until King George $v$, according to his own conception of the monarch's constitutional role as the guardian and spokesman of the 'national interest', put Baldwin squarely on the spot of 'duty' and 'patriotism', that the question became a live one. ${ }^{76}$ The role of the King was not necessarily unconstitutional, but it was a crucial factor, as a result of his taking the initiative on the subject of national government in his interview with Baldwin on 23 August, and in putting the party leaders under the double pressure of his personal appeal for co-operation and his insistence on an immediate solution. It was at his monarch's request that Baldwin, 75. Loc. cit.

76. Wigram's memo, 11 July 1931, RAM 2329/2, in Middlemas, K. and Barnes, J., Bald $\underline{\text { win }}$ (1969), p. 602 . 
in the words of the King's secretary, was willing "to risk party interests for the sake of the Country". 77

In the decision to form the national government, Samuel and the Liberals played a role second only to that of the king himself, and certainly one more significant than Baldwin, who was carried along by events, unable to shape their course. The idea was urged on the king by Samuel, and of all the three parties only the Liberals stood to gain from it. Naturally, they preferred to retain as Prime Minister and Chancellor figures who were not only free traders, but also with whom they had been dealing for two years. Furthermore, the formation of a coalition might postpone the election until the Liberals were better able to withstand the expected Conservative landslide - which it could be argued in fact they largely avoided in october. The Liberals would also gain office and find new prestige as well as a badly needed role, whilst also gaining their policy aims by playing one party off against the other. Economies would be achieved under Conservative pressure, but tariffs avoided by a free trade Liberal-Labour block. Alliance with the dogmatic Gladstonian Snowden established and confirmed at the Exchequer was hardly an advance on the road to protection along which Conservatives wanted to travel, but it suited the Liberals well. The formation of the national government was in fact a victory for samuel, for the 77. Wigram's memo, 23 August 1931, RAK 2330, in Nicolson, op. cit., p. 462 . 
bankers, and for the king in the sense that his view of the role and strengths of the British constitution was confirmed, but for no one else. 78

The rhetoric of the 'national interest' has elsewhere been examined in its influence upon the actions of the Labour leaders, but it should be pointed out that its influence was even greater upon the Conservative mind.79 The Conservative party as a whole reacted to the formation of the national government as a consequence of its selfperceived patriotic duty, and as a result of its belief that the nation was in acute peril, as serious and real as during the first world war. 80 The party chairman, Stonehaven, declared that "the Industrial, Social and Economic order was at stake",81 and elsewhere Conservatives accepted that the events were "unparalleled in the history of the country". 82 In such circumstances Baldwin expressed the view of the Conservative mind in accepting it as being their "bounden duty" to "put aside party differences for the time being in the national. interests", an attitude which Dawson in The $\underline{\text { Tim }}$ 트으

78. Wigram's memo, 24 August 1931, RAK 2330, ibid., p. 466; Hilton Young to his wife, 24 August 1931, Kennet MSS $107 / 3$.

79. Dare, op. cit., passim.

80. Astor to Munday, 5 September 1931, Astor MSS, $1416 / 1 / 1 / 1040$.

81. West Midlands Area, Exec., 18 September 1931.

82. SUA, Western Div. Council, 9 September 1931. 
commended for its "patriotic spirit". 83 Conservatives, even at the apex of the party, held comparatively unsophisticated conceptions of the proper role of both government and opposition during periods of national crisis; "it was [the Prime Minister's] duty to avoid that catastrophe and ours to do all we could to help him".84 In accordance with this, if the government did its duty, Conservatives promised to refrain from exploiting the opportunity for party gain, and would act equally responsibly. This was no small gesture, for the party was knowingly endangering its present position of being poised to win an election victory on the scale of 1924; that, in the words of one prospective Conservative candidate, "Mr. Baldwin sacrificed probably the greatest political advantages that anyone ever had - the glorious prospect of an immense Conservative majority". 85 In the light of the patriotic sacrifice of party, and the fact this did not lead, as was expected, to diminished popularity, should not obscure the rationale behind the party's response of 22 to 28 August.

The measure of Baldwin's reluctant acquiescence can be found in the document hammered out at the Buckingham Palace conference of 24 August, for of all the party 83. Baldwin in The Times, 24 August 1931.

84. N. to Anne Chamberlain, 23 August 1931, NC 1/26/447.

85. Bath CA, Special Meeting, 9 October 1931; Hailsham speech, The Times, 17 August 1931 ; N. to A. Chamberlain, 14 A unst 1931, AC 39/3/26; D. Marquand, "1924-1932" in D. Butler, ed., Coalitions in British Politics, pp. 61-62. 
leaders Baldwin was the most concerned to avoid entanglement in a coalition. This resulted in the emphasis not only upon the temporary and limited nature of the government, but in the explicit disavowal that it was "not a coalition but co-operation". 86 Baldwin placed much emphasis on the conception of the government as being the co-operation of certain individuals, and the declaration that "there is no question of any permanent coalition" was in fact all the more believable coming from the lips of the man most associated with the repudiation of the coalition in 1922.87 Indeed, it required all of Baldwin's trustworthiness to soothe the instinctive first reactions of a party for whom during the previous nine years the belief that 'England does not love coalitions' had become an article of faith. The inclusion of Labour figures was not the problem, for their presence was desirable psychologically, and their willingness to consider a revenue tariff suspected; however, coalition with such Liberals as Samuel and Lloyd George, who were deeply loathed by the Conservative party, was a more difficult pill to swallow. 88 For the same reasons Baldwin was keen

86. A. to Ivy Chamberlain, 24 August 1931, AC $6 / 1 / 800$; Baldwin to Hilton Young, 27 August 1931, Kennet MSS $4 / 8$.

87. Baldwin's press statement, 24 August 1931, The Times, 25 August 1931.

88. Ormesby-Gore to Baldwin, 24 August 1931, Baldwin MSS, volume 44, f. 50; Horne to N. Chamberlain, 15 August 1931, copy, ibid., ff. 25-34; Bridgeman to Salisbury, 9 October 1931, Salisbury MSS S(4) $141 / 112$; The Times, 21 August 1931. That Lloyd George was out of action due to iliness seems to have made comparatively little difference to this feeling. 
to keep the cabinet limited to only ten persons, for that again marked "the temporary and emergency character of the arrangement", as one of the excluded Conservatives acknowledged. 89

In selecting his colleagues to fill the other three of the four Conservative cabinet places, Baldwin offered his party further reassurance that the gains of the past year had not been surrendered. This he did over three crucial areas: tariffs, India, and the agitation against the 'Old Gang'. Two of his choices symbolised the tariff policy: Neville Chamberlain, a known protectionist and the architect both of the advances of October 1930 and of the Stornoway House agreement, and Cunliffe-Lister, who had overseen the drawing up of detailed tariff plans by the Research Department. The appointment of the third figure, Sir Samuel Hoare, to the India office was a crucial element, it being insisted that only a Conservative could fill this post without causing party unrest.90 All three symbolised the promotion of younger men in the leadership at the expense of the 'old Gang'. The omission of certain Conservatives from the national government has been perhaps given undue significance due to its later permanence. Several of the figures on the sidelines: Amery, Austen Chamberlain, Hailsham, and perhaps even Churchill, might have been included in the

89. A, to Ivy Chamberlain, 24 August 1931, AC 6/1/801.

90. Ibid., AC 6/1/802; Hilton Young to his wife, 26 August 1931, Kennet MSS $107 / 3$. 
less restricted confines of a Conservative government. The dispensation of August 1931 was only intended to be temporary, and the reason for their omission was not so much any political unorthodoxy as the need to maintain inter-party consensus by demonstrating that the '01d Gang' would not be allowed to dominate the next Conservative cabinet, a priority which even eased aside figures such as Peel and hailsham. That this exclusion was not permanent, but only temporary, was a theme Baldwin took great care in hammering home in his speech to the party meeting on 28 August, appeasing the excluded.

The theme of Conservative presentation of the new government revolved around the restrictions placed upon it: that it was temporary, that the parties would return to their previous positions, that it was limited only to dealing with the financial measures, that it did not compromise other policies, and above all, that it would swiftly lead to a general election. The emphasis on the temporary nature of the arrangements ran through all these aspects as a connecting theme. The limitation to enacting only an Economies Bill and passing a budget was crucial in the light of the Conservative tariff policy, 91 whilst Lord Lloyd publicly warned that the government "had no mandate to decide anything on India".92 In fact, the formation of the government was the result of the party having placed 91. Peel to Salisbury, 11 September 1931, Salisbury MSS S(4) $141 / 68$; The Times, 25 August 1931.

92. Bowyer to Fry, 27 August 1931, Baldwin MSS, volume 105 , ff. 63-67. 
economy first over tariffs in its programme since the spring of 1931 , as those who were uneasy over this priority were well aware, but the view that "first and foremost you must have drastic economy" which "alone will save the situation", and that the tariff battle would be fought afterwards, was held by an overwhelming majority of the party, and acquiesced in by the minority.93 Party unity was maintained by the explicit assurance that the tariff position had not been compromised, that the government would in a matter of weeks dissolve parliament for an election, and that nothing would be allowed to prevent this. This was important due to the widely held view in the party that, whilst economies were the shortterm solution to the nation's financial problems, only a tariff policy could restore long-term prosperity. Thus it was far more than merely a party shibboleth, but was seen and believed to be the other essential element in any national recovery. Moreoever, the crisis of August 1931 had served to add to the urgency of protection, for "we cannot recover any revenue or any industry now without a tariff" and so it was all the more necessary that the opportunity should not be lost now that public opinion had come around to the point where "we can carry protection in

93. Cunliffe-Lister to his wife, 21 August 1931, Swinton MSS, SWIN III (313) 1/5; 'Diary of Events during Crisis 1931', Steel-Maitland MSS, SRO GD. 193/120/3, ff. 443-448; Gwynne to Beaverbrook, 4 September 1931, Gwynne MSS, 14 . 
the country at an early general election".94 Page Croft vocalised this powerful sentiment, speaking for many backbenchers in his conditional approval of the formation of the national government, and writing to Baldwin on 25 August:

to congratulate you on the course you have taken in the national interest which I am sure is wise solong as the National Government confines its activities to carrying the Emergency Budget, and a dissolution takes place immediately the Budget is carried. I am personally of the opinion that there is no solution of our problem without an emergency tariff, and in giving my support to the government I do so only on the distinct understanding that a mandate is sought from the country for a tariff policy directly the immediate financial problem is solved.

\section{5}

An emergency session of the party's protectionist pressure group, the Empire Industries Association, of which Croft was chairman, had been summoned to meet on 27 August, and before addressing the meeting he requested from Baldwin, and received, "an assurance that nothing will be done to compromise the position of the party. with regard to Protection and Preference". 96

It is clear that acceptance of the formation of the national government by the Conservative party was far from 94. Orm sby-Gore to Baldwin, 24 August 1931, Baldwin MSS, volume 44, f. 50; this view carried all the more force for the fact that orm:sby-Gore was if anything associated with the free trade wing of the party; Gretton to Baldwin, 27 August 1931, ibid., ff. 60-61.

95. Croft to Baldwin, 25 August 1931, Croft MSS, CRFT $1 / 2 / B A 9$.

96. Loc. cit.; Baldwin to Croft, 26 August 1931, ibid., $\mathrm{BA} 10$. 
automatic, but dependend very directly on these conditional factors, in particular that the government was not to develop into a coalition, but was only a temporary expedient 1 imited in action to one area of polioy only, and that it would not only produce shortly a general election, but that in that contest the parties would return to their previous positions and fight independently for their own programmes.97 The national government was accepted by the party for two reasons: first, because of the repeated unequivocal reassurances given on all the above points by the party leaders - reassurance embodied in every point of the foundation document of the new ministry - and because the rank and file were swept along as much as their leaders by the extraordinary atmosphere of the crisis weeks, in a wave of patriotic sacrifice in the national interests. These two factors were the parallel hallmarks of the response of the rank and file, both in the formal meetings of 27-28 August, and in the reaction of Conservatism in the local Associations, to produce "a strong current of popular opinion in favour of unquestioned support of the National Government".98 In being swayed by the pressures of the crisis, the suddenness and scale of the run on sterling, the appeals for unity in the national interest, the party leadership reflected, rather than created, the mood amongst their 97. A. to Ivy Chamberlain, 24 August 1931, AC 6/1/800.

98. McCurdy to Beaverbrook, 3 September 1931, Beaverbrook MSS, C229. 
followers, and as a result the entry into the national government did not produce a rift between leaders and led,

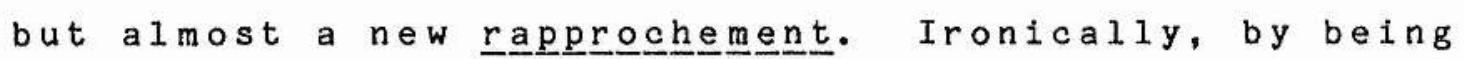
forced to sacrifice the party's interests Baldwin's stock rose dramatically in the eyes of his supporters, an approval of his statesmanship which went far to obliterate memories of his weaknesses as party leader in opposition during the previous two and a half years, and completed triumphantly the process of rehabilitation begun in the spring of 1931. The explanation of this was that on this occasion Baldwin's failure to act as a partisan leader for once accorded with the conceptions of the grassroots, rather than as previously conflicting with them.

Within days the momentum of approval had gathered irresistible force, as was demonstrated in the three meetings of the party's representative institutions at the end of the week, which had opened with the formation of the national government. The Empire Industries Association met first, on 27 August, expressing their fear that the emergency government might "put off the day when our constructive policy could be brought into being".99 Croft attended, and "with Baldwin's letter in my pocket" he gave his "wholehearted approval to the national government", 100 and after some rambling discussion the Association agreed on "a simple resolution of 99. Report of meeting, Bowyer to Fry, 27 August 1931 , Baldwin MSS, volume 105, ff. 63-67.

100. Croft, op. cit., pp. 190-191. 
confidence". 101 on the next day the official party meetings took place: an emergency session of the Executive Committee of the National Union, and a party meeting of MPs, peers and candidates at the Kingsway Hall to be addresed by Baldwin. At the former meeting the chairman of the National Union, Kingsley Wood, stressed again the temporary and emergency nature of the government, and concentrated their attention on the imminent general election, for which the party organisation must accelerate its preparations, and the tariff policy "strongly pressed home in the constituencies before the General Election took place" by continuing propaganda. Having been soothed by these assurances, the resolution moved by Derby approving the leader's action was passed unanimously. 102 The mood here matched that of the party meeting, which was "very dull and purely formal".103 Baldwin's speech candidly explained the events of the previous weekend:

I reached London on Saturday evening. I heard all that had passed, and late that night it seemed quite possible in the situation that then existed that we might be asked to form a government. I do not wish to say any more about that at this moment. On the Monday morning the crisis in the situation was literally a matter of hours .... It was in those circumstances that I was asked to meet the King with the Prime Minister and the acting leader of the Liberal Party. In the circumstances of that meeting and at that time there was nothing for anyone in my

101. 'Diary of Events During Crisis 1931', Steel-Maitland MSS, SRO GD $193 / 210 / 3$, ff. 443-448.

102. NU Exec., Energency Meeting, 28 August 1931.

103. Conway diary, 28 August 1931, Add. $7676 / 463$. 
position to do but promise full co-operation to tide over this crisis.

Thus did Baldwin account for not having held out for a Conservative government, making it clear that the eventual decision for a national ministry, though accepted by him, had been neither his desire nor suggeistion. The reassurances were then once more produced:

when the economies are carried and the budget is balanced you will then have a straight fight on tariffs and against the Socialist Parity.

Those not included in the new government were assured that this "will not prejudice their position in the future" Conservative government, and Baldwin closed with a typical appeal to the instincts of loyalty and unity: "Let us pull together .... We shall, I believe, succeed in saving the pound sterling. Meantime our party's position and programme on the tariff question remains intact." The resolution of support was moved by three figures associated with the anti-Baldwinite right wing: Gretton, Hailsham, and Page Croft. All set their seal of approval on the new government, although none welcomed it. Gretton warned that even the modest amounts of new taxation would be "grievous to us all" and must be "a temporary sacrifice" until the revenue tariff could come to the 104. The Times, 29 August 1931. 
rescue in relief both of taxes and of the number of unemployed. Croft noted that the new cabinet had a free trade majority, but accepted with Hailsham that due to lack of time there was "not a possible alternative". The mood of the party was evident in the reactions from the floor of the meeting, where "everyone present appeared to approve entirely of [Baldwin's] line of action", 105 and "at the end there was round after round of cheering and then 'someone in the hall started 'God Save the King' and it was sung impressively". 106 what was being cheered, however, was not a party victory, but the patriotic sacrifice of party in the national interest, for, as croft noted at the meeting, many MPs "were much disgruntled that Conservatives should have been jockeyed out of their certain victory". 107

The mood of the party expressed at the Kingsway Hall was consistent with the reactions of the grassroots of the party throughout the country, both north and south, rural and urban. Baldwin had "justified the trust in him by putting country before party in the present crisis". 108 Both the imperative circumstances and the electoral risks were acknowledged:

While admitting that Mr. Baldwin and his colleagues could not, in the interests of the Country, have done

105. Headlam diary, 28 August 1931.

106. A. to Ivy Chamberlain, 28 August 1931, AC 6/1/806. 107. Croft, op. cit., p. 192.

108. Waterloo CA, Council, 4 September 1931. 
otherwise, the Chairman said he felt that the Unionist party might be in danger of being blamed for the economies which had to be effected as the result of the mismanagement of the late government.

The reaction of the grassroots was sometimes unconsciously inconsistent, declaring at the same time that "we must think of the nation" and that "we [must] not deviate from tariffs", but approval of the decision was unanimous. 110

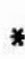

The dynamic of the events during the short life of the first national government was contained within these assumptions made at its inception, above all that it would lead to an early election where nothing would be allowed to obstruct the party campaigning for a 'free hand' on tariffs. The national government could only exist so long as it accommodated these internal requirements of its dominant constituent element, as it proceeded to do in stages from September 1931 until September 1932. It was only as a result of this process that the government which on its initial formation in August 1931 was a development unfavourable to the Conservative party, and thus intended only to be a temporary necessity, became a 109. Glasgow Unionist Association, 7 September 1931.

110. Peterborough CA, Exec., 3 October 1931; SUA, Western Div. Council, 9 September 1931; Ealing CA, Exec., 31 August 1931; Lewes CA, 21 September 1931; Melton CA, Exec., 3 October 1931; Uxbridge CA, Council, 12 September 1931; York CA, Annual Report 1931; Petersfield CA, 13 October 1931; Abingdon CA, Council, 26 September 1931; Bath CA, Exec., 8 September 1931; East Midlands Area, Exec., 22 September 1931 . 
configuration of more utility than liability. This reduced the incentive to terminate the new alliance. Once the national government had been pressurised and moulded to the extent that it became based upon not one, but both pillars of the Conservative economic policy, of economies and protection, it became acceptable to the party. At the same time the results of the 1931 general election heralded a new political consensus powerful enough to dominate British politics for the following decade, and thus the objections of both policy and pragmatism evident in the last week of August evaporated. It is for this reason that the explanation and origins of the radical restructuring of British politics after 1931 lie not in the events of 20 to 28 August, but in the changing attitudes during September and October. When formed the government was genuinely intended by Baldwin to be temporary. By nature an optimist in politios, and certainly not immune to the appeals of patriotism in the national interest, he appears to have assumed that the future course of events was guaranteed by the conditions which had been written into the founding agreement of 24 August. In the event, it proved more and more difficult for the national alliance to break up, as the prospect of the parties returning to their respective positions receded, and Baldwin found himself entering the election as part of the national coalition with MacDonald as premier. One consequence of this was the political 
impossibility of reshaping the second national government in the image of its backbench supporters, although by November Baldwin had probably ceased to wish to do so, finding the new arrangement increasingly congenial, both in personal relations, and in the political concerns not only of protection but also of India. Nonetheless, if after October 1931 Baldwin became reconciled to the position of second figure in a national administration, it is equally evident that he had been opposed to this idea in August. The new two-grouping system of national coalition versus a purged Labour party, which replaced the unstable three-party politics of the 1920 's, was forged after the actual formation of the national government on 24 August 1931. As the attractions of the alliance began to displace the notion of a return to previous positions, and as the pressure of events with the collapse of the gold standard and the renewed political attack of the Labour party set the conditions whereby an election as a referendum for the national government became necessary, so the arrangement developed from the emergency stage to become the permanent 'national' coalition of the 1930's. 


\section{CONCLUSION}

\section{Power and Authority in Conservative Politics}

It is the principal argument of this thesis that the political crises of the early 1930's transformed the composition and position of each of the British political parties and their relationship with each other and with the public at large. In particular, it is suggested that in the specific case of the Conservative party, the crucial period in which incipient transformations in direction and outlook became crystallised into the pattern in which they remained set until the aftermath of the second world war, if not longer, was the period of internal crisis whilst in opposition to the second Labour govenment of June 1929 to August 1931; the only time between the end of the first world war and the end of the second that the Conservatives were not the largest party in the House of commons. As a result of these developments during the period of opposition, the formation of the national coalition - an event seen initially as a temporary divergence from normality - found the Conservative party united around certain policies, specific attitudes, and particular leaders, having already evolved a political posture for the issues of the foreseeable future. In the process of examining this principal concern, it is necessary to examine and explain the nature of Conservative politioal activity - its conventions and morality - the structure of the party, the distribution of power within it and the pressures which 
could be brought to bear upon it from below or without. The Conservative party has always been as much a matter of men as of measures in its essential character, and thus against the mechanics of policy formulation and the identification of the roles of different elements in the hierarchy, must be set the political influence and therefore the political fortunes of the party leadership, and above all, of the leader. These aspects will therefore be briefly reviewed, as the necessary structural and narrative backgrounds to the evolution of Conservatism from the erratic and uncertain position of the period from the Edwardian era to the later 1920's, to the secure and confident dominance of the British political scene which it had established in the late 1930's, and from which it could be argued that only the cataclysm of war cast it down.

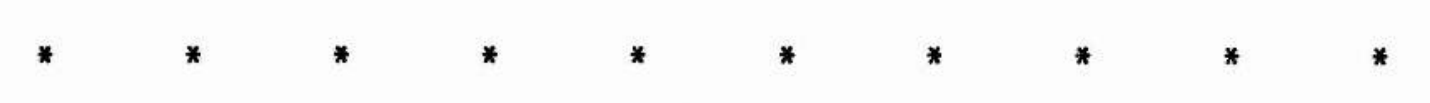

The first background theme to emerge from this study concerns the position of the party leader. This is revealed as possessing considerable institutional powers, and considerable political resources. The leader alone and individually had the widest discretion, both in the direction of party policy, which only he could authoritatively pronounce, and in the selection of persons to fill key posts in the party hierarchy. Furthermore, the party leader was well placed to exploit the traditional claims of loyalty, and was able to exploit to 
his personal political advantage the party's natural instinct for unity. This latter tended normally to manifest itself in a closing of the ranks around the leader's chosen position, thus having the effect of putting the onus for causing disunity on any dissident elements. This in turn was reinforced by the fact that during times of crisis, or when the party was under outside attack, the luxury of internal dispute tended to be swiftly abandoned in favour of a united front. In general, then, the leader of the Conservative party possessed in this period an immensely powerful position, either for creative initiation, or as a strong defensive position. Nevertheless, the party leader was by no means immune from internal criticism or even direct attack, nor was he isolated from the pressures and demands of external forces and events. The leader of the party was expected to fulfil three requirements: first, to give an adequate lead on the floor of the House of Commons to the parliamentary party - a role in which he could be assisted but not substituted for by other leading front benchers; second, to satisfy the party supporters in general by accommodating the policy of the party to at least a minimum level that accorded with their continued adherence - the one way in which the leader could be portrayed as divisive was in failing in this area; and third, to provide some prospect of leading the party to victory at the polls. To be secure, the party leader needed to perform satisfactorily in at least two of these areas, and 
his position would become untenable if he failed on two or all three for anything beyond a short period.

The third Marquis of Salisbury, although Prime Minister in the Lords, had most successfully filled all these roles, whilst Balfour, though successful in the first area, fell down on both the second and the third in the last stage of his leadership. Bonar Law was satisfactory in the electional arena, and was always careful to accommodate the grassroots on policy, but was always weakened by his failure in the first aspect; whilst Austen Chamberlain fell in 1922 because, notwithstanding all the strengths of the leader's position, he markedly failed in all three; in particular, as a result of his decision not to lead the Conservatives to the expected election as an independent force. Baldwin as leader from 1923 to 1929 had usually been adequate in the House of Commons, with his occasional oratorical triumphs and the abilities of his front bench colleagues to some extent masking a certain erratic quality to his performances, and he was also until the period immediately before the 1929 election satisfactory in his definition of policy. This in particular helped him to survive the 1923 defeat relatively easily, for apart from the problem of there being no suitable alternative figure, the defeat had been the result of the policy which the party rank and file endorsed. However, after the 1929 election this was not the case, and Baldwin's position became seriously exposed. 
The longer spell in opposition revealed clearly his weaknesses as parliamentary leader, whilst both his choice of platform in the election, and his definitions of policy from the election until 0ctober 1930 were significantly out of tune with a large element, although not except perhaps at the peak of crisis in September 1930 a majority element, of his followers in the Commons and in the constituency associations. The influence of the third area - the prospect of electoral victory - was more complicated. On the one hand Baldwin's limited policy before October 1930 was unacceptable to the tariff wholehoggers who believed that only a vigorous policy could attract votes, whilst on the other hand it was widely accepted that Baldwin, despite all his faults, was an electoral asset with the voters at large, for whom there existed no suitable replacement figure. There can, however, be no doubt that the party crisis, though it was caused by dissatisfaction over the first two areas - of parliamentary performance and of party policy - was first exacerbated by the frustrations of the electoral situation from May 1929 to March 1931, during which for the first part the party trailed behind a popular Labour administration, and then during the second part seemed to be unable to gain any advantage from the growing unpopularity of that government. Then, by precisely the same process, the party crisis was dampened down by the visible swing back of support to the Conservatives from February 1931 onwards; which culminated in the soothing 
influence of the 'whiff of victory' scented in the byelections of June 1931. This combined with the fact that since october 1930 the party policy in the most crucial areas had become acceptable; in the solution of the tariff question, the primacy of the economy issue, and, even after a period of anxiety in late 1930 and early 1931 , over India provided the promised safeguards were secured. It was this situation which brought about the isolation of the press lords' campaign, and the restoration of order in the party. Baldwin's position had certainly come close to a collapse of the confidence without which no leader could successfully function, but on each occasion it had been staved off, so that the end of the period under study found him in a position as strong as that he had held in 1924 to 1926, and probably stronger than that of 1927 to 1929, when he had frequently been out of step with the political concerns of his rank and file.

There is no simple explanation of Baldwin's success in maintaining his position during the serious phases of the party crisis, in particular between November 1929 and November 1930. This was rather the product of the interplay of a number of factors. Defensively, Baldwin had made good use of the loyalty card, whilst at the same time he had endeavoured to accommodate the party policy to the twin - and at first conflicting - demands of party opinion and public opinion. Baldwin was malleable on policy for two reasons: first, he sought the path of 
least potential disunity within the party; and second, his negativism was not rooted in himself as the result of objections of principle, but as the expression of electoral pragmatism was directly related to the state of public opinion in the key regions of the Midlands and the North where the party had to regain seats in order to win an election. He had also exploited the weaknesses of his critics: their disunity, and the tactical weaknesses of their methods, as well as the fact that the pragmatists in the party, who were the majority, were uphappy about adopting extremist or Diehard positions. The matter of political methods was especially important, and it was in this area that Baldwin had succeeded in altering the substantive issue from ends to means, and carried the day by playing the constitutional card, and as a result split the protectionists against each other from June 1930 onwards.

Many of Baldwin's problems were, consciously or otherwise, of his own making. In policy the choice to resist empire free trade was partly deliberate electoral pragmatism, and partly the reluctance of an experienced statesman to become tied to a policy which he believed could not be put into practice. But the strains set up in denying the instincts of many of his more vocal followers were exacerbated by his personal failures. Baldwin's own mood during the party crisis was a mixture of nervousness and complacency, irresolution and sudden counterattack. These are conflicting descriptions, but they represent a 
complex and often contradictory personality, whose moods and conduct were widely variable, and who for much of the period under discussion was under considerable political stress. He was most often criticised for his complacency, although its cause may have been instinctive appreciation of the latent strengths of his position as much as any lack of appreciation of the difficulties in which he found himself. The combination of complacency and indecision was the product of his reliance on his skill in understanding and creating a political 'atmosphere', and of the conflicting signals which this was sending at different times and from different regions. Baldwin opted for safety first in his timing of policy advances, and if there was any error, it was on the side of delay. This was certainly a political weakness in Baldwin's character, and there were others that contributed to his difficulties betwen 1929 and 1931. He lacked tact and was uncommunicative in his personal handing of both his principal colleagues, and of his backbenchers. He hung on dangerously to certain individuals who were deeply unpopular in the party, first Davidson and later Irwin, out of a sense of personal loyalty. His personal preference for the 'Old Gang', and consequent frustration of a rising clique of younger MPs, was another source of weakness, for few of the young MPs were antagonistic to his policies. Most important of all, however, was his personal failure to fill the accepted role of leader of 
the opposition in the normal, partisan, sense - a failure which left many of his followers feeling that the party had lost both its policies and its sense of purpose. In the event it proved that these weaknesses of Baldwin's position, though they did strain internal relationships in the Conservative party, and thus in part contributed to the existence of a leadership crisis as well as a policy crisis, were not so great or so long-lasting as to outweigh the strengths of his position. Baldwin survived as leader by exploiting these, by his often underestimated skills of timing, by his occasional but crucial oratorical successes, by the disunity and lack of political respectability of his opponents outside the party, by the general loyalty of his colleagues and the majority of MPs, by the hamstrung position of those within the party on the occasions when they sought to move against him, and by a certain amount of luck.

The events of the period in opposition during 1929 to 1931 also illuminate the practical process of formulating party policy. This could be described as the process of arriving at an equation acceptable to the widest possible range of party opinion and of public opinion; to balance the considerations of electoral pragmatism with the need to keep the flame of party spirit burning brightly. of course, it would not always be true to posit a direct contradiction between party opinion and public opinion, for after all both are affected by the same social and 
economic factors, and party opinion is only an element in the wider area of public opinion generally. The distinction is more usually one of degree, and is significant only where the party opinion is central to the partisans' raiㅗ음 d'etre, and yet conflicts with the majority or consensual public attitude on the question in focus. Thus party opinion could become in tune with public opinion in one area, such as tariffs or economy, yet out of tune at the same time in another area, such as disarmament and the role of the League of Nations, or the proper functions of the House of Lords. This affected the political position of the party in relation to the issues in the limelight of public attention. On this criterion the Conservative party was out of tune with public opinion, especially on the most important economic issue, at the time of the 1929 general election, and remained so until the end of that year. During 1930 the two moved independently onto a converging course, so that by 1931 party and public were broadly of the same mind on what both saw as the foremost crisis of the day. This position was created before the August 1931 financial crisis, but that crisis and the events of August to October 1931 further increased the degree of affinity, so that the election of 1931 produced a victory at the polls of a greater scale even than that which the party had been looking forward to before the crisis broke.

Party policy was the result of four elements of party opinion. The party leader was influenced by his 
need to retain a consensus amongst the front bench leadership; the requirement to maintain the morale, confidence, and unity of the parliamentary forces; the pressures expressed generally from the sectors and classes amongst whom the party found its support; and the specific expressions of these from the grassroots, through the representative institutions of the local associations and of the National Union, and through their local Member of Parliament. Public opinion was a more amorphous concept, but attention was specifically directed to the state of opinion in the marginal regions, and to the results of byelections. The evolution of party policy was clearly the result of attempting the most satisfactory compromise solution. However, as all the individuals or groups involved were located in and involved with the concerns of one specific area, the reception of the policy solution varied widely. It was these concerns as much, if not more, than any simplistic left-to-right linear spectrum of political position within the framework of Conservatism, that created the political 'atmosphere'.

In the case of party opinion, the significant factors were the gradual products of the trend from being a party based on a landed interest, to a party based upon business or commercial concerns, and the operation in parallel with this of the growing insularity of political concern which was leading to the primacy of domestic issues over those of Britain's imperial status. In the case of public opinion, the slump produced a swing in favour of 
protection, which also reduced the popularity of the Labour government. The latter had been generally welcomed as a change on its election in May 1929, but was increasingly seen to be ineffective, in particular in dealing with the economic and unemployment problems. Specific Conservative policies were directly related to these shifts in opinion. The tariff issue reflected the failure of 'safety first' to secure public support in the election, and the pressure of other sectors of business, such as iron and steel, that the existing policy of safeguarding should be much extended in its application. The aspect of imperial preference, however, was soon being set aside in the interests of domestic interest groups. of these, agriculture was the less successful, partly because the balance of power in the party had shifted to the world of industry and finance, and partly because public opinion was less likely to accept a tariff on cheap food imports. The question of India failed to achieve primacy due to the emphasis on insular politics, whilst the issue of economy outstripped both tariffs and India in the party rhetoric of 1931 precisely because it was the one area where party opinion and public opinion seemed to be closest. The national peril had secured the centre of the political stage, but its influence had not yet peaked, for the idea of any coalition was still vigorously ruled out on the eve of the financial crisis in August 1931. 
The interplay of these policies and of the roles of the leader and the rank and file, of party and of public opinion, have all been followed through the six stages of the politics of the Conservative party's period in opposition to the second Labour government, and have provided the framework for their categorisation and examination. The first phase, from the election defeat of May 1929 to the summer recess in August 1929 was categorised by successful caution on the part of the leadership over policy as a result of the wide divergence between public opinion and party opinion. In the case of the latter, a critique of both the causes of the election defeat and the defects of current policy began to put pressure on the party leadership during the second stage, from September 1929 to February 1930, for some advance of party policy to protection of industry at least, if not also of agriculture. This pressure was vocalised by Beaverbrook's Empire Crusade campaign, but had its roots in the party rank and file of southern England. During this phase the party leadership strove to concede as little as possible as slowly as possible, for very good reasons of electoral pragmatism. The party itself was by no means completely favourable to protection, and in the Northern urban areas in particular it was unpopular with both party and with public opinion. Thus the advances made by the party leader, in speeches at the 1929 conference, at the Coliseum, and at the Hotel Cecil, were all of rhetoric rather than substance, and the key policy 
to agriculture was repeatedly postponed. Nonetheless, throughout the period, but with increasing force from early 1930 onwards, business opinion and public opinion, even in former free trade strongholds, was moving towards protection - a movement which by the end of the 1930 's had become such a landslide that even food taxes no longer provoked the same hostile response. Thus adjustments of policy became possible, and the cautious first of these, at the Hotel Cecil, enabled a truce to be made with the press campaign which reduced the effectiveness of the rank and file movement; and this third phase, March to June 1930, gave the leadership a breathing space to set their house in order. This was achieved, partiy through unveiling a popular agricultural policy, partly through dropping the highly unpopular party chairman Davidson and replacing him with Neville Chamberlain, and partly through exploiting the growing tactical rift on means which was opening up between the press lords and their sympathisers at all levels of the party. Thus, when the truce collapsed, the party leadership were able during the fourth phase, June to October 1930, to counterattack with the cry of loyalty and play the constitutional card against press power. The first party meeting was summoned by the leaders to register approval of the changes of June 1930 and was swung by an assault on Rothermere into doing so. This restoration of control could not last, for it had not satisfied the real causes 
of unrest, either on policy or by providing a proper forum for discussion.

Thus the most acute phase of crisis occurred in September 1930 as a result of the fact that the rift between the leader's position and that of the rank and file was at its widest. Baldwin appeared to be failing in all three aspects of leadership: his Commons performances were visibly unsatisfactory, his policy was unpopular, and he provided no prospect of electoral victory. In addition he was losing control over party opinion, amongst his colleagues, amongst the MPs, and more broadly in the country as a whole, where perhaps for the only time in his career the loyalty of the chairman of the local associations and of moderate majority opinion in them wavered. Recovery was achieved in october 1930 by accommodating grassroots pressure on policy, as a response not to the crusade but to the imperial conference. Thus the fifth phase, November 1930 to March 1931, saw the first stage of the restoration of control, with the second Caxton Hall meeting confirming the appeasement of internal opinion, whilst the advance of public opinion made such appeasement possible. However, during this fifth phase doubts over the India policy, and over Baldwin's personal capacity, produced a renewed but less dangerous atmosphere of leadership crisis in February and March 1931. This Baldwin dealt with by adjusting his policy, and above all, by re-establishing his personal mastery over the parliamentary party with the speech of his career on 12 
March 1931, a more important event than the turning of the party against the press attacks after the debacle of East Islington, which manifested itself in Duff Cooper's victory at the concurrent st. George's by-election. In the sixth and final phase, March to August 1931, the restoration of order was completed by the fact that the leadership, party opinion, the attitudes of the party support groups, and public opinion had found common ground in placing foremost on their agenda the danger of national bankruptcy, to which the solution was to be economy. On this policy and this ordering of the four-point programme there was no disunity, and the encouraging signals of the by-elections of summer 1931 denoted that Baldwin was once more proving satisfactory in all three of the leader's roles, vis a vis parliament, policy, and the public.

The role of the press in a parliamentary democracy provides the third area of structural investigation, and the events of 1929-1931 were commonly, but mistakenly, held to illustrate first an attempt at press dictatorship, and then the defeat of that attempt at the the st. George's by-election. In reality, the relationship between party and press, and the political role of the press, was much more complicated than such a simiplistic model would suggest. The Conservative press in general, not just the press lords' mass circulation papers, but also the more prestigious metropolitan papers 
such as The Times, the Morning Post, the Daily Telegraph, and the observer, and the varied range of major provincial. papers such as the Glasgow Herald and the Yorkshire Post, acted as a forum for the development and presentation of issues of policy within the party. Their role was to vocalise both public opinion, as did The Times in its espousal of national government during the financial. crisis, and party opinion, as did Beaverbrook's and Rothermere's papers over empire free trade, and later India. The press was not a creative factor in its own right, but was a medium of expression for opinion formed elsewhere, and a sounding board for the formal, in its columns, or informal, in discussion with its owners and editors, debating of party policy and strategy. The role of men such as Dawson, Garvin and Gwynne, no less than Beaverbrook, was as crucial in their private activities as confidants, advisors and mediators, as it was in their public printed leaders. The Conservative press had no institutionally defined relationship with the party structure or with the leader, for it was largely a matter of personal interaction, but it is clear that they possessed an important if informal role, somewhere between the significance of front bench and back bench MPs, but all the more important for their possession, in their newspapers, of a certain independent power base, and thus a certain freedom of comment, action, and opinion. Viewed in this light, the Conservative press is a linear spectrum of lesser or greater affinity with the party's given 
policies in which Dawson would be found closest to Baldwin's position, Garvin on tariffs and Gwynne on India rather less so, and Beaverbrook and Rothermere simply further removed still. Various Conservative newspapers at different points in the party's history had attempted to marshall and vocalise rank and file resentment against the official position, and the activities of Beaverbrook and Rothermere were novel only in their scale of activity, not in their intention.

The strength of the Empire Crusade was not in the large circulation of the newspapers which supported it, though there is no doubt that their initial advocacy helped to get it started in a spectacular fashion, but in the fact that it was able to mobilise a significant proportion of disaffected Conservatives at the lowest levels of the party and amongst the general public. It was these people who gave substance to the newspapers' shadow army, and it was the MPs who reflected their views, either from sympathy or from simple necessity, who gave the dissatisfaction its parliamentary dimension. The Empire Crusade, however, as Beaverbrook himself acknowledged, was based not on the backbenchers, but on the constituencies of the Conservative strongholds of the southern half of England. Beaverbrook's campaign also suffered from a number of weaknesses, principal amongst which was its dependence on the one-man-band dynamism of its principal promoter. The loneliness of his position, 
and the mistaken belief that press circulation was the cutting edge of the Crusade, led Beaverbrook to his alliance with Rothermere, but this alliance was itself a tactical weakness. Initially, until the South Paddington election, the validity of Beaverbrook's publicising role was widely accepted - in February and March 1930 by Baldwin himself - and even for some months after the collapse of the truce and the first Caxton Hall meeting in June 1930 many Conservatives drew a distinction between the political respectability of the two press lords. There was a tendency to polarise all the odium on Rothermere, and all the tolerance on Beaverbrook. The alliance with Rothermere was thus the barrier to successive attempts to come to terms after June 1930. The picture changed radically after October 1930 for once the difference on policy largely disappeared, so did the continued justification for the Crusade's pressure - as was recognised by Melchett and Elibank by their withdrawal. The motive could now be condemned as one of personality - not a respectable cause - and Beaverbrook could be placed in the dock as the instigator of party disunity. The by-election strategy after South Paddington backfired - and it was above all in his reckless attempts at East Islington that Beaverbrook, already isolated, lost the last shreds of support. This was the situation which Baldwin confirmed - but did not create - in March 1931 by his emphasis on the constitutional question at st. George's. The verdict at St. George's was firstly a 
condemnation of the conduct and the result of the East Islington by-election, and secondly reflected the fact that the issue of economy was already beginning to take precedence over the issue of protection, which had been settled to the satisfaction of all but an unimportant minority by the policy advance to the 'free hand' in october 1930. Thus the press campaign blew hot and cold in direct relation to only one factor - the degree of Conservative grassroots support which it vocalised. The pressure of the crusade was built on this foundation, and manifested itself not through the newspapers which promoted it, but through the orthodox political actions of recruiting members, raising funds, and running or threatening to run candidates at by-elections or at the general election. It is for this reason that the history of the Empire Crusade belongs with the history of pressure groups, and not with the history of journalism.

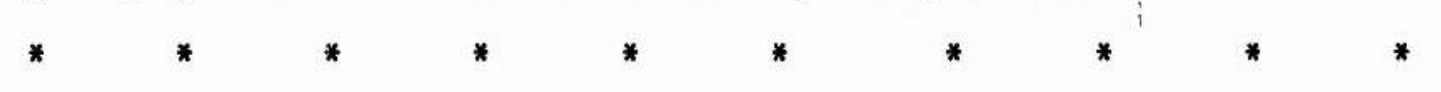

Although the Conservative party was unexpectedly and unintentionally directed by the pressure of circumstances - of public opinion, of the royal intervention, and by the emotions and rhetoric of the 'national interest', into forming the national government in August 1931, the evolution of that government after its initial crisis phase, from October 1931 onwards, was consistent with the position to which Conservatism had evolved by July 1931. This was the basic reason for the continued success of the 
national government, and the absence of any rebelion along parallel lines to that which had occurred in 19211922 against the Lloyd George coalition. The national government was also preserved because it was seen to be the only solution to the economic problem, and because of its electoral viability. But the Conservative party rank and file would have been restless - far more so than they ever became over India - had they not found it satisfactory on political essentials, and these, by the early 1930's, were domestic, not imperial.

The policy outlook of the national government of 1931 to 1935 was formed by the Conservative party during 1930 and 1931. Economy, and the deflationary solution to the slump, were placed in the foremost position. The reduction of taxation and the reduction of expenditure, especially on the 'luxury' area of social services, were the specific means of a policy designed to revitalise investment and thus employment. Hand-in-hand with this, although in second place, was the commitment to the tariff barrier and protection of industries as the long-term solution. This was now approached in the spirit of insular protection, not by way of empire unity. Above all, the crucial political decisions about the future constitution of India, and the attitude of the Conservative party towards that measure, had already been taken before the national government was formed, although this fact was not yet apparent to the Diehards and to the rank and file. The long drawn out debate over India 
between 1932 and 1935, although important enough to cause much concern in the party, demonstrated first the fact that the majority of the party were already committed to devolution in principle; second, the new consensus and control established by Baldwin after March 1931; and third the factor on which that consensus was based - that domestic issues came first and that in the last resort the Conservative party would neither reject its leader nor smash the national government for the sake of disputes over India.

The changes which came to fruition in the Conservative party during the period in opposition formed the image of Conservatism in the 1930's, an image in which the dominance of the party by the concerns of business led it into political options not always in its own best interests, and left a political legacy in the popular image of Conservatism which contributed significantly to the rejection of the party in the general election of 1945. This was seen in the area of unemployment policy; in the pay and dole cuts of 1931, the introduction of the Means Test, and the policies associated with the Unemployment Assistance Board; and the decline of the prosperity of the 'special areas'. It was seen in the relationship of the party to the coal owners' interest again evident in 1937. But above all it was associated with the faiiures to re-arm; the refusal to organise or compel industry in any way; the dilemma over the question 
of legitimate profits; and the debacle of the National Defence Contribution of 1937. ${ }^{1}$ Finally, the result of this atmosphere produced the unhappy period of 'phoney war' in 1939-1940.

The character and composition of the Conservative leadership in the 1930's was also forged during 1929-1931. The continued dominance of Baldwin, who was not seriously challenged again, was the less important aspect of this. More significant was the elevation of the group who were to dominate conservative politics during the following decade. These included figures who had come into the front rank in the period of opposition, such as Irwin, Cunliffe-Lister, Kingsley wood, and of the younger men Duff Cooper, Oliver Stanley, and Orm;sby-Gore. Above all, the period 1929-1931 saw the emergence of the triumvirate who came to dominate the party after the departure of Baldwin, if not before: Simon, Hoare and Neville Chamberlain. Chamberlain rose from a position of some importance to the position of undisputed deputy during the period 1929 to 1931. The Research Department, and much more the tenure of the party Chairmanship, were the foundations for the first stage of this progression, and they enabled him to decisively influence events in October 1930 and in March 1931. His return to a new position of prestige on the front bench after March 1931 and in particular his successful lead in the attack on the

1. R. P. Shay, British Rearmament in the Thirties: Politics and Profits $(197 \overline{7})$, pp. $92-93,-\frac{1}{246-263}$. 
government from the debates over the 1931 budget onwards, completed his rise. The events of 1931 also set one crucial limit upon it: that as Baldwin's crown prince, he would have to bide his time until Baldwin chose to retire, an event for which he had to wait another six years. Nonetheless, as Chancellor of the Exchequer in the national government from November 1931 onwards, Neville Chamberlain was marked as the political strong-man of the administration. This was emphasised by the exclusion, either completely in the case of Amery, Horne and Churchill, or partially but effectively, in the case of Hailsham and Austen Chamberlain, of other potential leaders. In fact the events of 1929-1931 produced, below the position of Baldwin himself, a complete restructuring of the Conservative leadership, which marked the second stage of development of the leadership which had been established in 1922 upon the ruins of the Lloyd George coalition. The changes of 1929-1931, which replaced new extremists such as Amery and Churchill, with new forces for stability such as Simon and Runciman, confirmed the political verdict of 1922. The leadership which emerged in the period of opposition, the policies upor which their control and consensus were based, and the political and organisational structures upon which they depended, proved durable until the cataclysm of war in 1940 upset the political equilibrium established in 1931. 


\section{Bibliography}

For abbreviations used, see list below:

CA Constituency Association

Ctte Committee

MSS Manuscripts and Papers

NUA National Unionist Association

Ro Record office

SUA Scottish Unionist Association

Where no other location is given, primary sources remain with their original owners. In the case of secondary sources, unless otherwise stated, place of publication is London.

$\therefore$

I. Primary Sources

1. Private Papers

(a) Conservative Leadership

Amery Diary

Baldwin MSS

Balfour MSS

Bridgeman MSS

Bridgeman Political Journal

Austen Chamberlain MSS

Neville Chamberlain MSS
Barnes, J. and Nicholson, D., eds. The Leo Amery Diaries, Volume 1 (1980).

Cambridge University Library

British Library

Shropshire RO

Courtesyof Lor d Bridgeman

Birmingham University Library

Birmingham University Library 
Churchill MSS

Davidson MSS

Derby MSS

Halifax MSS

Halifax MSS

Salisbury MSS

Steel-Maitland MSS

Swinton MSS

Templewood MSS

$\therefore \quad$ Worthington-Evans MSS
Gilbert, M., ed., Winston S. Churchill, Companion Volume 5, Part 2 (1981).

House of Lords Record office

Liverpool RO

India office Library

Borthwick Institute, York University

Hatfield House, Hatfield, Herts.

Scottish RO

Churchill College, Cambridge University

Cambridge University Library

Bodleian Library, oxford University

$\begin{array}{ll}\text { (b) Conservative MPs and } & \frac{\text { Candidates }}{\text { Reading University }} \\ \text { Astor MSS } & \begin{array}{l}\text { Cobrary } \\ \text { Bayford Diary }\end{array} \\ \text { Beamish MSS } & \begin{array}{l}\text { Churchill College, } \\ \text { Cambridge University }\end{array} \\ \text { Conway MSS } & \begin{array}{l}\text { Cambridge University } \\ \text { Library }\end{array} \\ \text { Croft MSS } & \begin{array}{l}\text { Churchill College, } \\ \text { Cambridge University }\end{array} \\ \text { Elliot MSS } & \text { National Library of } \\ & \text { Scotland } \\ \text { Gower MSS } & \text { Central Library, } \\ & \text { Tunbridge Wells } \\ \text { Hammersley MSS } & \text { Manchester Central } \\ \end{array}$


Hannon MSS

Haslam MSS

Headlam Diary

Kennet MSS

Lee Diary

Moore-Brabazon MSS

Morrison-Bell MSS

Selborne MSS

(c) Empire Crusaders

Beaverbrook MSS

Elibank MSS

Lockhart Diary
Blumenfeld MSS

House of Lords Record office

Lincolnshire RO

Durham County RO

Cambridge University Library

Clark, A., ed. A Good Innings: The Private Papers of Lord Lee of Fareham (1974).

Royal Air Force Museum, Hendon

House of Lords Record Office

Bodleian Library, oxford University

House of Lords Record office

House of Lords Record office

Scottish RO

Young, K., ed., The Diaries of Sir Robert Bruce Lockhart, Volume 1: 1915-38 (1973).

Times Newspapers Archives Bodleian Library, Oxford University

Bodleian Library, Oxford University

Wrench MSS
British Library 
(e) Miscellaneous

\begin{tabular}{|c|c|}
\hline $\begin{array}{l}\text { Empire Industries } \\
\text { Association MSS }\end{array}$ & $\begin{array}{l}\text { Economic Research } \\
\text { Council, London }\end{array}$ \\
\hline $\begin{array}{l}\text { Indian Empire Society MSS } \\
\text { (Stuart MSS) }\end{array}$ & $\begin{array}{l}\text { Bodleian Library, } \\
\text { Oxford University }\end{array}$ \\
\hline Jones Diary & $\begin{array}{l}\text { Jones, T., ed, A Diary } \\
\text { With Letters }(1954) \text {. }\end{array}$ \\
\hline $\begin{array}{l}\text { National Farmers Union } \\
\text { MSS }\end{array}$ & $\begin{array}{l}\text { Institute of Agricultural } \\
\text { History, Reading }\end{array}$ \\
\hline Nicolson Diary & $\begin{array}{l}\text { Nicolson, N., ed., } \\
\text { Diaries and Letters: } \\
\text { Volume } 1,1930-39 \\
(1966)\end{array}$ \\
\hline Whitehall Diary & $\begin{array}{l}\text { Middlemas, K., ed., } \\
\text { Thomas Jones: Whitehall } \\
\text { Diary, Volume 2: 1926- } \\
1930(1969) \text {. }\end{array}$ \\
\hline
\end{tabular}

2. Conservative Party Records

(a) National Records

National Union, Executive Ctte, Minutes \}

National Union, Reports of Executive Ctte, to Central Council

National Union, CentralCouncil Minutes

Conservative

Union, Jarchive,

National Union, Labour Advisory Sub-Ctte, \}Bodleian

Minutes

Library,

NUA, Annual Reports of Council

\}oxford

NUA, 1929 Conference Agenda and Minutes \}University

NUA, 1930 Conference Agenda and

Transoript

National Union Ctte Papers, etc. in

Steel-Maitland MSS

Scottish RO

National Society of Conservative Agents Westminster City Library 


\title{
(b) Regional and City Records
}

SUA, Executiveand CentralCouncil Minutes s Scottish SUA, Annual Conference Minutes.

SUA, Eastern Divisional Council

SUA, Western Divisional Council

Central

Office,

\} Edinburgh

East Midlands Area

Eastern Area
West Midlands Area

Bodleian Library, Oxford University

Yorkshire Area

Cornwall County Division

Bodleian Library, Oxford University

Somerset County Division

Bodleian Library, Oxford University

Kent Agents Union

Canterbury CA

Birmingham $\mathrm{CA}$

Birmingham Reference

Library

Bradford CA

Glasgow CA

Bradford Central Library

Scottish Central office,

Edinburgh

Leeds CA

Sheffield CA

Leeds City Archives

Sheffield Central

Library

\section{(c) Constituency Records}

\author{
Abingdon CA \\ Accrington $\mathrm{CA}$ \\ Ashford CA \\ Barkston CA \\ Basingstoke CA \\ Bath CA \\ Bewdley CA \\ Blackpool CA \\ Bradford Central CA \\ Bradford East CA \\ Bradford South CA \\ Bridgeton CA \\ Camborne CA \\ Cannock CA \\ Canterbury CA \\ Chelmsford CA \\ Chelsea CA \\ Chichester CA
}

Manchester University

Library

Leeds City Archives

Bath RO

Worcestershire RO

Lancashire RO

Bradford Central Library

Bradford Central Library

Bradford Central Library

Scottish Central office

Cornwall Ro

Templewood MSS, VI(1)

Cambridge University

Library

West Sussex RO 


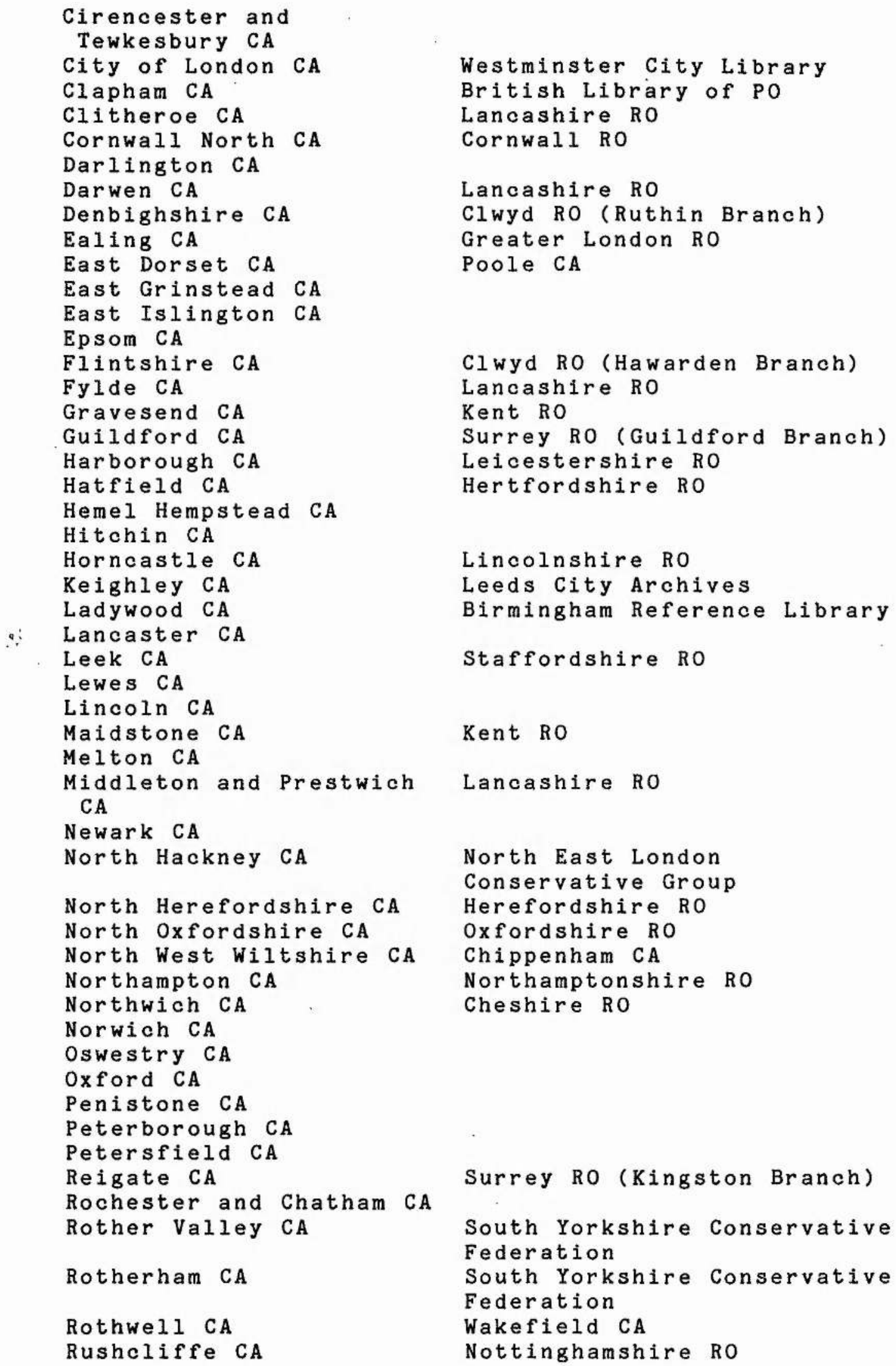

Westminster City Library British Library of PO

Lancashire RO

Cornwall RO

Lancashire RO

Clwyd RO (Ruthin Branch)

Greater London RO

Poole CA

Clwyd RO (Hawarden Branch) Lancashire RO

Kent RO

Surrey RO (Guildford Branch)

Leicestershire RO

Hertfordshire RO

Lincolnshire RO

Leeds City Archives

Birmingham Reference Library

Staffordshire RO

Lancashire RO

North East London

Conservative Group

Herefordshire RO

Oxfordshire RO

Chippenham CA

Northamptonshire RO

Cheshire RO

Surrey RO (Kingston Branch)

South Yorkshire Conservative Federation

South Yorkshire Conservative Federation

Wakefield CA

Nottinghamshire RO 
Rutland and Stamford CA

St. Albans CA

St. George's CA

Sheffield Central CA

Sheffield Ecclesall CA

Sheffield Park CA

South East Cornwall CA

South Kensington CA

South Oxfordshire CA

Southport CA

Stafford CA

Stockton CA

Stone CA

Torquay CA

Uxbridge CA

Wakefield CA

Walsall CA

Warwick and Leamington CA Warwickshire RO

Water $100 \mathrm{CA}$

Wells CA

West Derbyshire CA

West Dorset CA

West Leeds CA

West Wolverhampton CA

West Woolwich CA

Wood Green CA

Worcester CA

York CA

Westminster City Library

Sheffield Central Library

Sheffield Central Library

Cornwall RO

Oxfordshire RO

Staffordshire RO

Durham RO

Staffordshire RO

Lancashire RO

Derbyshire Ro

Dorset RO

Leeds City Archives

c/o Prof. G. Jones,

Department of Government, London School of Economics

Greater London RO

York City Archives

\section{(d) Party Publications}

Ashridge Journal \} Conservative Central Conservative Agents Journal\} office

Gleanings and Memoranda

Home and Politics

\}

(becomes Home and Empire (as localised edition

from March 1931 onwards) entitled: Northampton

Conservative Journal)

\section{Newspapers}

Daily Express

Daily Mail

Daily Telegraph

Evening News

Evening Standard

Morning Post

Observer

Times

Sunday Express 


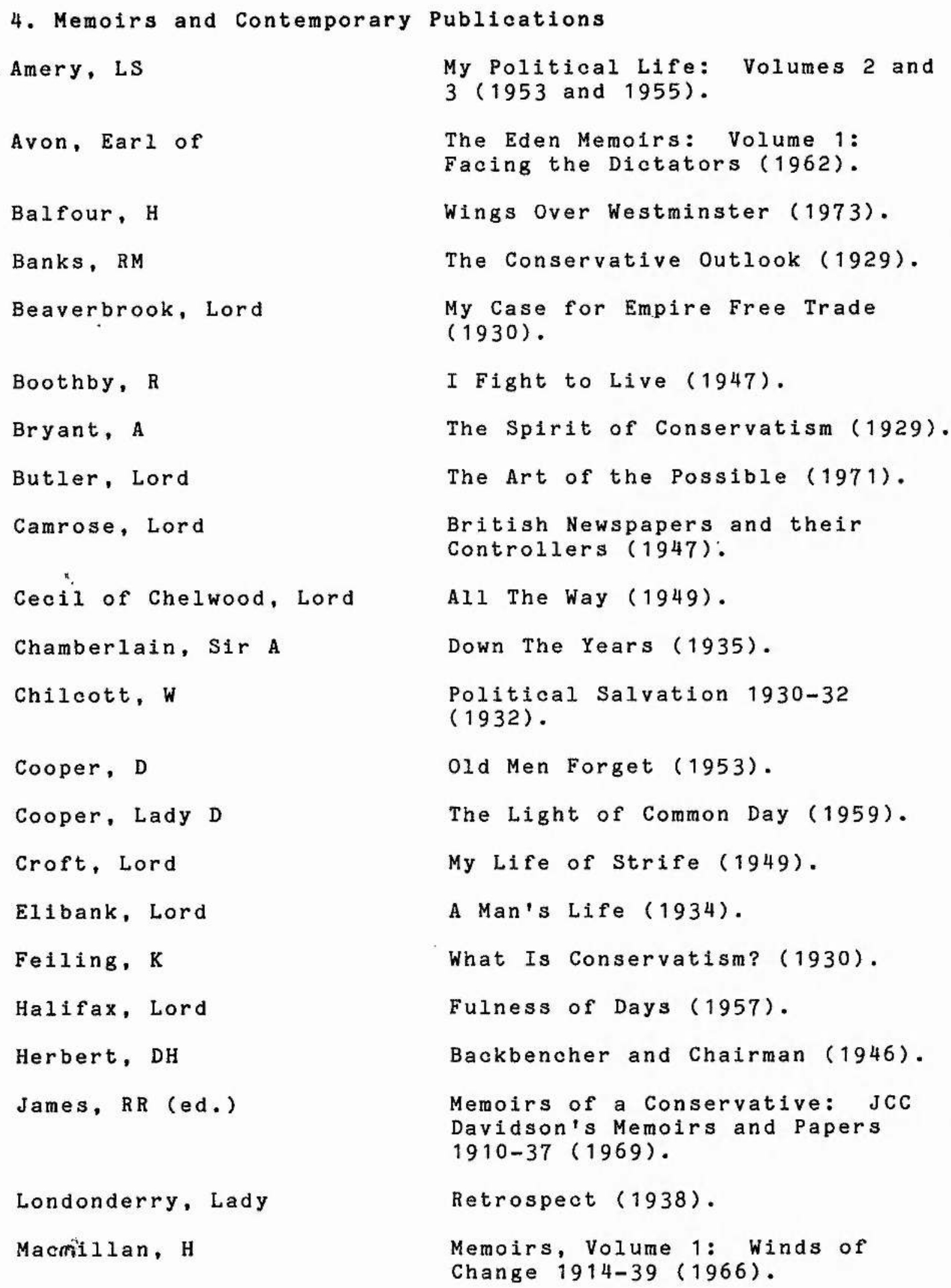




\author{
Midleton, Earl of \\ Moore-Brabazon, JTC \\ Oman, Sir C \\ Percy, Lord E \\ Percy, Lord E \\ Portsmouth, Earl of \\ Rentoul, Sir G \\ Samuel, viscount \\ Simon, Viscount \\ Stuart of Findhorn, Lord \\ Swinton, Lord \\ Templewood, Viscount \\ Winterton, Earl \\ Zetiand, Lord
}

\section{Secondary Sources}

1. Biographies

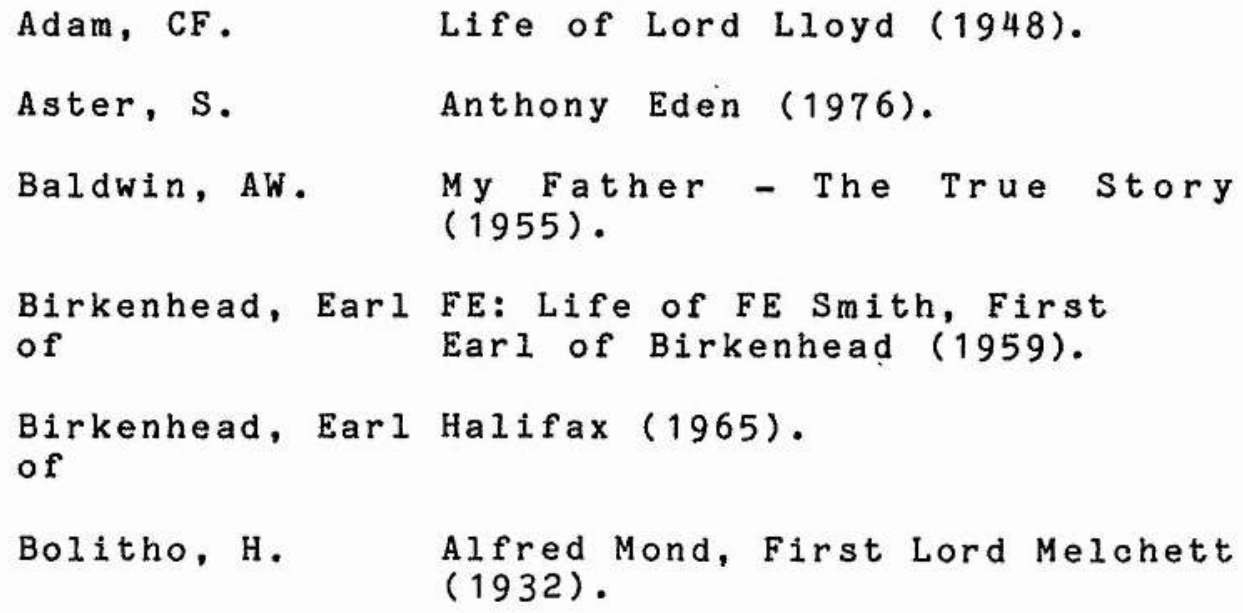




\begin{tabular}{|c|c|}
\hline Brodrick, AH. & $\begin{array}{l}\text { Near to Greatness: Life of the } \\
6 \text { th Earl Winterton }(1965) \text {. }\end{array}$ \\
\hline Bowle, J. & Viscount Samuel (1957). \\
\hline Boyle, A. & Poor, Dear Brendan (1974). \\
\hline Bryant, A. & Stanley Baldwin (1937). \\
\hline Campbe11, J. & $\begin{array}{l}\text { Lloyd George: The Goat in the } \\
\text { Wilderness 1922-1931 (1977). }\end{array}$ \\
\hline Carlton, D. & Anthony Eden (1981). \\
\hline Churchill, R. & $\begin{array}{l}\text { Lord Derby: King of Lancashire } \\
(1959) \text {. }\end{array}$ \\
\hline Coote, C. & $\begin{array}{l}\text { A Companion of Honour: the story } \\
\text { of Walter Elliot }(1965) \text {. }\end{array}$ \\
\hline Cross, JA. & Sir Samuel Hoare (1977). \\
\hline Cross, JA. & Lord Swinton (1982). \\
\hline Driberg, $\mathrm{T}$. & $\begin{array}{l}\text { Beaverbrook: A Study in Power } \\
\text { and Frustration }(1956) \text {. }\end{array}$ \\
\hline Eade, C (ed.). & $\begin{array}{l}\text { Churchill By His Contemporaries } \\
(1953) \text {. }\end{array}$ \\
\hline Egremont, $M$. & Balfour $(1980)$ \\
\hline Elletson, DH. & The Chamberlains (1966). \\
\hline Feiling, $\mathrm{K}$. & $\begin{array}{l}\text { Life of Neville Chamberlain } \\
(1946) \text {. }\end{array}$ \\
\hline Gilbert, M. & $\begin{array}{l}\text { Winston S. Churchill, Volume 5: } \\
\text { 1922-39 (1976). }\end{array}$ \\
\hline Green, J. & $\begin{array}{l}\text { Mr. Baldwin: A Study in Post-War } \\
\text { Conservatism }(1933) \text {. }\end{array}$ \\
\hline Heuston, RFV. & $\begin{array}{l}\text { Lives of the Lord Chancellors } \\
1885-1940(1964) \text {. }\end{array}$ \\
\hline Hyde, HM. & Baldwin (1973). \\
\hline Hyde, HM. & Neville Chamberlain (1976). \\
\hline Hyde, HM. & Lord Reading (1967). \\
\hline James, RR. & Victor Cazalet (1976). \\
\hline
\end{tabular}




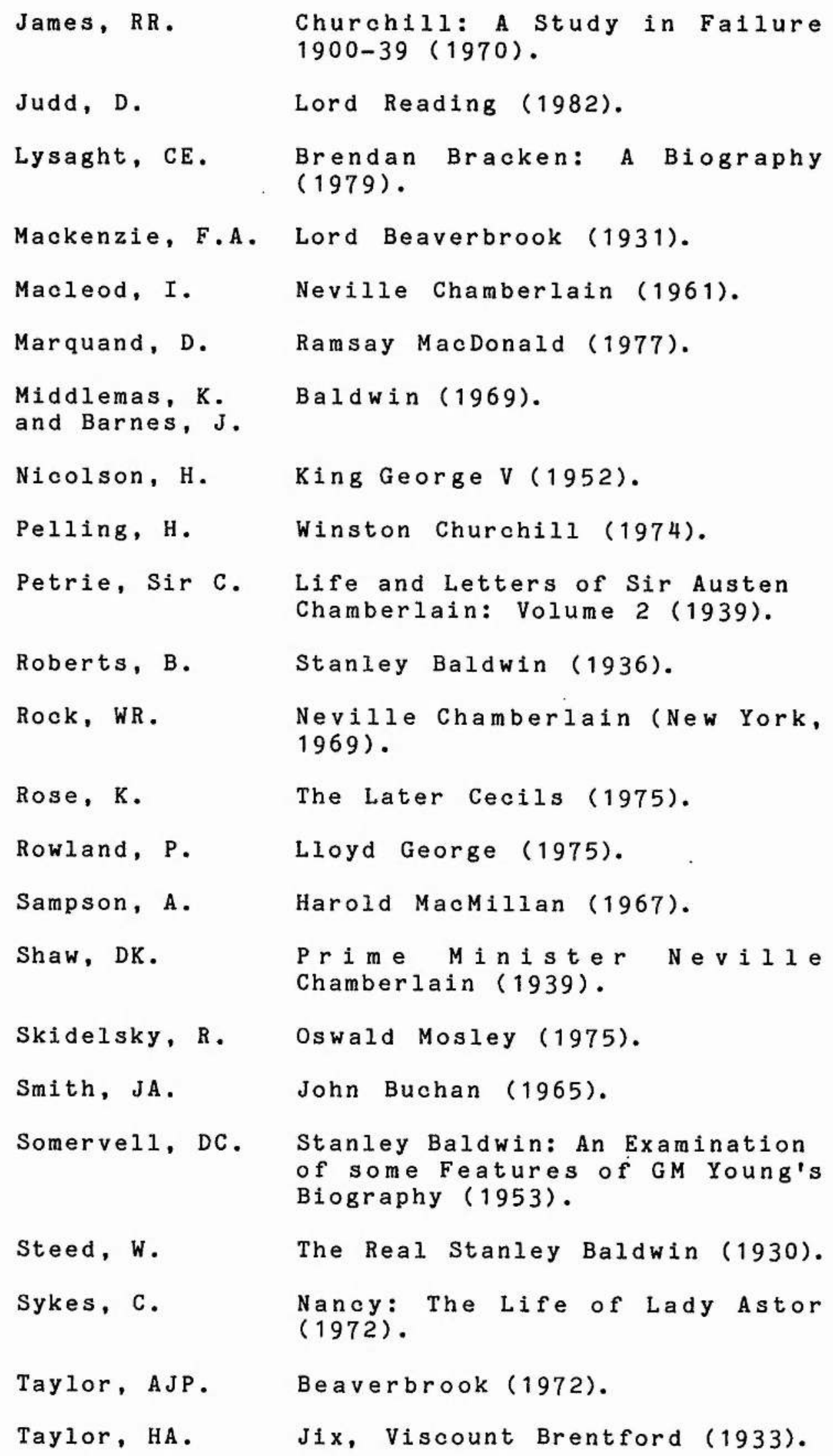


Wrench, JE.

Young, GM.

Young, $\mathrm{K}$.

Young, $\mathrm{K}$.

Young, $\mathrm{K}$.

Zebel, SM.

2. Books

Basset, R.

Bealey, F ,

Blondel, J. and

McCann, W. F.

Bentley, M.

Berkeley, H.

Blake, R.

Blake, R.
Geoffrey Dawson and Our Times (1955).

Baldwin (1976).

Arthur James Balfour (1963).

Baldwin (1976).

Churchill and Beaverbrook $(1966)$.

Balfour (1973).
1931: Political Crisis (1958).

Constituency Politics: A Study of Newcastle-under-Lyme (1965).

The Liberal Mind 1914-29 (Cambridge, 1977).

The Myth That Will Not Die: The Formation of The National Government 1931 (1978).

The Conservative Party from Peel to Churchill (1970).

The National Union 1867-1967 (1967).

Boyce, G, Curran Newspaper History: From the 17 th P., et. al Century to the Present Day (1978).

Bromhead, PA. The House of Lords and Contemporary Politics 1911-1957 $(1958)$.

Brookes, P. Women at Westminster: an account of Women in the British Parliament 1918-1966 (1967).

Butler, D (ed.). Coalitions in British Politics $(1978)$.

Butler, D.

The Electoral System in Britain Since 1918 (second edition, Oxford, 1963). 
Butler, Lord (ed.)

Cambray, PG

Carlton, D.

Comfort, Go.

Cook, C and Ramsden, J., eds.

Cowling, M.

Cowling, M.

Cudlipp, H.

Dean, KJ.

Douglas, R.

Drummond, IM.

Fawcett, A.

Goodhart, P. and Branston, U.

Granzow, B.

Guttsman, WL.

Gwyn, WB.
The Conservatives (1977).

The Game of Politics (1932).

MacDonald versus Henderson: The Forelgn Policy of the Second Labour Government (1970).

Professional Politicians: A Study of the British Party Agents (Washington, 1958).

By-Elections in British Politics (1973).

The Impact of Hitler: British Politics and British Policies 1933-40 (Cambridge, 1975).

The Impact of Labour 1920-24 (Cambridge, 1971).

The Prerogative of the Harlot: Press Barons and Power (1980).

Town and westminster: A Political History of Walsall (Walsall, 1972).

History of the Liberal Party 1985-1970 (1971).

British Economic Policy and the Empire (1972).

Conservative Agent (1967).

The 1922: The story of the Conservative Backbenchers Parliamentary Committee (1973).

A Mirror of Nazism: British Opinion and the Emergence of Hitler 1929-1933 (1964).

The British Political Elite (1963).

Democracy and the cost of Politics in Britain (1962). 
James, RR.

Jones, GW.
The British Revolution: Volume 2: British Politics 1914-1939 (1977).

Borough Politics: A Study of the Wolverhampton Town Council 18881964 (1969).

Layton-Henry, Z. Conservative Party Politics ed. $(1980)$.

Lindsay, T. F. The Conservative Party 1918-1979 and Harrington (1979).

M.

McKenzie RT. British Political Parties (1955).

McKenzie R. T. Angels in Marble (1967). and Silver, $A$.

Middlemas, K. Politics in Industrial Society (1979).

Nordlinger, E. The Working-Class Tories (1967).

Norton, $P$, and Conservatives and Conservatism Aughey, A. (1981).

Petrie, Sir C. The Carlton Club (1955).

Petrie, Sir C. The Powers Behind the Prime Ministers (1958).

Ramsden, J. The Age of Balfour and Baldwin 1902-40: History of the Conservative Party, Volume 3 $(1978)$.

Ramsden, J. The Making of Conservative Party Policy: The Conservative Research Department Since 1929 $(1980)$.

Raymond, J., The Baldwin Age (1960). ed.

Robb, J.

The Primrose League (New York, 1942).

Seymour-Ure, C. Press, Politics, and Public $(1968)$. 
Shay, RP.

Sked, A, and

Cook, C.

Sked, A. and

Cook, C.

Skidelsky, R.

Stevenson, J. and Cook, C.

Southgate, D. , ed.

Sykes, A.

Thompson, N.

Wilson, T.

Young, K.
British Rearmament in the 1930's: Politics or Profits (Princeton, 1977).

Crisis and Controversy (1976).

Post-War Britain (1979).

Politicians and the Slump: The Labour Government of 1929-31 $(1967)$.

The Slump: Society and Politics during the Depression (1977).

The Conservative Leadership 1832-1932 (1974).

Tariff Reform in British Politics 1903-13 (Oxford, 1979).

The Anti-Appeasers: Conservative Opposition to Appeasement in the $1930^{\prime}$ s (Oxford, 1971).

Wiener, M. J. English Culture and the Decline of the Industrial Spirit 18501980 (Cambridge, 1981).

The Downfall of the Liberal Party 1914-35 (1966).

Local politics and the Rise of Party: The London Municipal Society and the Conservative Intervention in Local Elections 1894-1963 (Leicester, 1975).

\section{Articles}

Beattie, A.

Beichman, A.
Neville Chamberlain (Mackintosh, JP, ed., British Prime Ministers in the Twentieth Century, volume 1, 1977).

Hugger-Mugger in Old Queen Street: The Origins of the Conservative Research Department (Journal of Contemporary History, volume 13 , 1978). 
Bridge, C.

Brown, J. M.

Campbe11, J.

Cannadine, D.

Close, D. H.

Close, D. H.

Dare, R.

Dean, D. W.

Fair, J. D.

Fair, J. D.

Ghosh, S. C.
Conservatism and Indian Reform 19291939 (Journal of Imperial and Commonwealth History, volume 4, 197576 ).

Imperial Facade: Some Constraints upon and contradictions in the British position in India 1919-35 ( Royal Historical society, Transactions, 5 th Series, volume 26 , 1976 ).

Stanley Baldwin (Mackintosh, JP, ed., British Prime Ministers in the Twentieth Century, volume 1, 1977).

Politics, Propaganda, and Art: The Case of Two Worcestershire Lads (Midland History, volume 4, number 2 , 1977):

The Collapse of Resistance to Democracy: Conservatives, Adult Suffrage, and Second Chamber Reform 1911-28 (Historical Journal, volume 20,1977 ).

Conservatives and Coalition after the First World War (Journal of Modern History, volume 45, 1973).

British Labour, the National Government, and the 'National Interest', 1931 (Historioal studies, volume $18,1978-79$ ).

Conservatism and the National Education System 1922-40 (Journal of Contemporary History, volume 6 , number 2, 1971).

The Conservative Basis for the Formation of the National Government of 1931 (Journal of British Studies, volume 19,1980$)$.

The Second Labour Government and the Politics of Electoral Reform 1929-31 (Albion, volume 13, 1981).

Decision-Making and Power in the British Conservative Party: A Case Study of the Indian Problem 1929-34 (Political Studies, volume $13,1965)$. 
Glickman, H.

The Toryness of English Conservatism (Journal of British studies, volume 1, number 1, 1961).

Layton-Henry, Z. Democracy and Reform in the Conservative Party (Journal of Contemporary History, volume 13 , 1978).

Mckibbin, R. I. The Economic Policy of the Second Labour Government 1929-31 (Past and Present, No. 68,1975$)$.

Mandle, W. F. Sir Oswald Mosley's Resignation from the Labour Govenment (Historical Studies, volume, 1961).

Marwick, A.

Middle Opinion in the Thirties: Planning, Progress, and Political Agreement (English Historical Review, volume 79,1964$)$.

Peele, G. Revolt over India (Peele, G. and Cook, C., eds., The Politics of Reappraisal 1918-39).

Rasmussen, J. G. Government and Int ra-Party opposition: Dissent within the Conservative Parliamentary Party in the 1930's (Political studies, volume $19,1971)$.

Seymour-Ure, C. The Press and the Party System Between the Wars (Peele, G. and Cook, C., eds., The Politics of Reappraisal 1918-39).

Williamson, P. Safety First: Baldwin, the Conservative Party, and the 1929 General Election (Historical Journal, volume 25,1982 ).

4. Theses

Bayliss, G. M. The Outsider: Aspects of the Political Career of Alfred Mond, $1 \mathrm{st}$ Lord Melchett (University of Wales Ph. D., 1969). 
Dean, D. W.

Dugdale, K.

Higbie, C.

Holland, R. F.

McEwen, J. M.

Mills, M. A.

Ramsden, J.A.

Rolf, K. W. D.
The Contrasting Attitudes of the Conservative and Labour Parties to Problems of Empire 1922-36 (University of London Ph. D., 1974).

Conservatives, Liberals, and Labour in Yorkshire 1918-29 (Sheffield University M. A., 1976).

The British Press in Selected Political. Situations (University of London Ph. D., 1977).

Britain, the Dominions, and Political change 1926-37 (University of Oxford D. Phil., 1977).

The Unionist and Conservative Members of Parliament 1914-39 (University of London Ph. D., 1959).

The Development of Parliamentary opposition in Britain 1906-45 (University of London Ph. D., 1970).

The Organisation of the Conservative and Unionist Party in Britain 19101930 (University of Oxford D. Phil., 1975).

Tories, Tariffs, and Elections: The West Midlands in English Politics 1918-35 (University of Cambridge Ph. D. , 1975).

Shorter, P. R. Electoral Politics and Political Change in the East Midlands of England $1918-35$ (University of Cambridge Ph. D., 1975).

Turner, D. R. The Shadow Cabinet in British Politics, with particular reference to its development since 1922 (University of Wales M. A., 1966).

Wallis, P. V.
London Electoral Politics 1918-1935 (University of Cambridge Ph. D., 1974). 